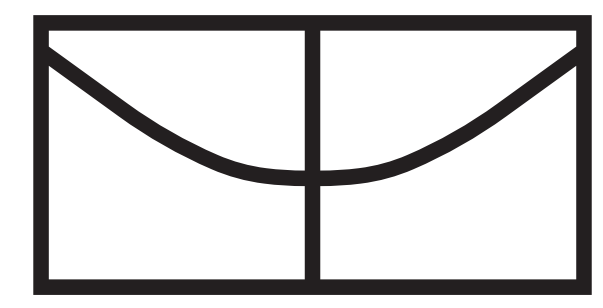

UNIVERSIDADE DE BRASÍLIA

FACULDADE DE COMUNICAÇÃO

PROGRAMA DE PÓS-GRADUAÇÃO

LINHA DE IMAGEM, SOM E ESCRITA

GABRIELA PEREIRA DE FREITAS

\title{
Da Estética do Fluxo à Estética em Fluxo: Experiência e Devir entre Artemídia e Comunicação
}




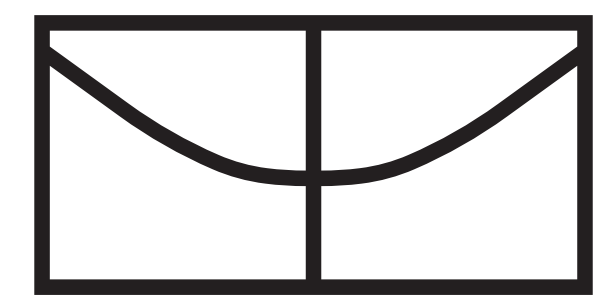

UNIVERSIDADE DE BRASÍLIA

FACULDADE DE COMUNICAÇÃO

PROGRAMA DE PÓS-GRADUAÇÃO

LINHA DE IMAGEM, SOM E ESCRITA

GABRIELA PEREIRA DE FREITAS

\section{Da Estética do Fluxo à Estética em Fluxo: Experiência e Devir entre Artemídia e Comunicação}

Orientador: Prof. Dr. Gustavo de Castro e Silva 


\section{DA ESTÉTICA DO FLUXO À ESTÉTICA EM FLUXO: EXPERIÊNCIA E DEVIR ENTRE ARTEMÍDIA E COMUNICAÇÃO}

Tese apresentada ao Programa de Pós-Graduação em Comunicação Social da Universidade de Brasília, e defendida sob avaliação da Banca Examinadora constituída por:

Prof. Dr. Gustavo de Castro e Silva

Orientador

Universidade de Brasília

Profa. Dra. Selma Regina Nunes Oliveira

Membro Interno

Universidade de Brasília

Profa. Dra. Florence Dravet

Membro Externo

Universidade Católica de Brasília

Profa. Dra. Claudia Linhares Sanz

Membro Interno

Universidade de Brasília

Prof. Dr. Massimo Canevacci

Membro Externo

Universidade de São Paulo

Prof. Dr. Frederico Antonio Cordeiro Feitoza

Suplente

Universidade Católica de Brasília 
Para meus amores Angelo e Eduardo 


\section{AGRADECIMENTOS}

Ao amor da minha vida, Angelo, pelo carinho, apoio, cuidado, paciência, por nossa família, por me ajudar a tornar esse processo mais leve. Ter você ao meu lado foi essencial para conseguir chegar até aqui.

Ao meu filho querido, Eduardo, por me fazer esquecer tudo com um sorriso.

Aos meus pais, Vanildo e Rosário pelo amor, por tudo que sempre fizeram por mim, principalmente à minha mãe, por me ensinar a valorizar a busca pelo conhecimento.

Ao meu irmão, Guilherme, pelo carinho, pelo apoio, mesmo distante.

Ao professor Gustavo de Castro que acompanhou esta trajetória desde o início e a quem agradeço muito pela orientação cuidadosa e pelos ensinamentos que me mostraram os caminhos estéticos e poéticos da Comunicação.

Aos professores Florence Dravet, Ana Beatriz Barroso,

Suzete Venturelli e Sérgio de Sá, pelas contribuições valiosas no momento de qualificação e que muito me ajudaram a prosseguir na pesquisa.

Ao querido amigo Mike, pelas conversas acadêmicas, pela troca de ideias mas, principalmente, pelo carinho e amizade.

Ao professor Alberto da Silva, da Université Sorbonne Paris-IV, pelo apoio durante o período do sanduíche, pela orientação, conversas e pela amizade.

Aos colegas professores Wagner Rizzo, Selma Oliveira, Fabíola Calazans, Luciano Mendes, Duda Bentes, Tânia Montoro, Kátia Belisário, Délcia Vidal e Ellis Regina pelo apoio, conversas, trocas de ideias e até mesmo momentos de desabafo.

À professora Nancy Berthier, da Université Sorbonne Paris-IV, por me receber junto ao CRIMIC para a realização do estágio de doutoramento.

À CAPES pelo apoio financeiro que tornou possível o doutorado sanduíche.

A todos os amigos que de alguma forma me incentivaram e entenderam minhas ausências. 
BILHETE A HERÁCLITO

Tudo deu certo, meu velho Heráclito, porque eu sempre consigo atravessar esse teu outro rio com o meu eu eternamente outro... 


\section{RESUMO}

FREITAS, Gabriela P. Da Estética do Fluxo à Estética em Fluxo. Experiência e Devir entre Artemídia e Comunicação. 2014. 225f. Tese (Doutorado em Comunicação) - Curso de Pós-Graduação em Comunicação Social, Universidade de Brasília, 2014.

Orientador: Prof. Dr. Gustavo de Castro e Silva

Defesa: 28/11/2014.

Nesta pesquisa buscamos compreender melhor a noção de fluxo, vocábulo constantemente utilizado na contemporaneidade, principalmente em estudos das áreas sociais, incluindo a Comunicação. Partimos de uma investigação etimológico-filosófica que se voltou às raízes portuguesas, latinas e gregas da palavra, bem como aos primeiros pensamentos realizados acerca dessa noção em Heráclito (535 a.C. - 475 a.C), na Grécia. Suas reflexões serviram como guia no diálogo estabelecido com outros filósofos que o repercutem, como Platão, Giordano Bruno, Heidegger, Hegel, Nietzsche, Bergson e Deleuze. Em seguida, por compreender que o fluxo se manifesta de forma estética, procuramos compreender como ele se engendra e, dessa forma, nossos esforços se voltaram à concepção de um método capaz de abordar um objeto sem tirá-lo de seu fluxo, ou de seu movimento. Para tanto, buscamos aliar os princípios intuitivo e analítico, como propõe Bergson, levando em conta a experiência do pesquisador e tomando a descrição, tal como a entende Maffesoli, como importante recurso para o desenrolar da análise. Tanto a vivência da experiência quanto o momento posterior de análise procuraram se estabelecer sobre um tripé teórico metodológico constituído pelo diálogo entre as áreas da Filosofia, da Ciência e das Artes, como propõe o método da complexidade de Edgar Morin. Procuramos ainda criar momentos de suspensão (tal como a epoché husserliana) que possibilitassem articular tais conhecimentos. Encontramos nas Artes um campo profícuo para investigação do fluxo, principalmente na Artemídia pois, ao se apropriar de meios de comunicação em seu fazer artístico, ela antecipa usos estéticos que posteriormente constituirão a própria Comunicação, num devir midiático das artes, como aponta Ivana Bentes. As obras escolhidas se constituem como instalações que convidam ao percurso e à imersão, levando ao deserolar de um trajeto antropológico (conforme Durand) que é sedimentado pela experiência. Dessa forma, chegamos à compreensão de uma Estética do Fluxo que implica em um fluxo da estética - Estética em Fluxo - constituída por categorias-fenômeno como a da Oscilação e a da Topologia Imaginária, compostas, respectivamente, pelas subcategorias do ritmo e do hibridismo; e do devaneio e da imersão. Percebemos, ao longo do estudo, a importância da dimensão social, da busca pelo outro que leva a uma procura por transcendência, que se dá de forma imanente (trans-imanência). Essa dinâmica nos remete, finalmente, de volta à Comunicação. Reconhecendo as manifestações da Estética em Fluxo, encontramos algumas recorrências e apropriações pela Comunicação e apontamos caminhos para futuros estudos na área, direcionando-nos para a relação homemmáquina por meio da interface, dentre outras questões.

Palavras-chave: Fluxo; Heráclito; Estética; Experiência; Artemídia; Comunicação 


\begin{abstract}
In this research we propose a new understand of the notion of flux, a constantly used word nowadays, especially in the areas of social studies, including Communication. We start from an etymological and philosophical investigation looking at the Portuguese, Latin and Greek roots of the word as well as the first thoughts about this concept presented in Heraclitus (535 BC - 475 BC), Greece. His reflections served as a guide to establish a dialogue with other philosophers like Plato, Giordano Bruno, Heidegger, Hegel, Nietzsche, Bergson and Deleuze. Then, by realizing the flux manifests itself in an aesthetic way, we explore how its aesthetics engenders and therefore, our efforts turned initially to design a method capable of addressing an object without taking it out of its flow, or its movement. To this end, we combine the intuitive and analytical principles, as proposed by Bergson, taking into account the experience of the researcher and taking the description, as understood by Maffesoli, as an important resource for the analysis. Both the experience and the later moment of analysis sought to consolidate themselves over an theoretical-methodological tripod constituted on a dialogue between the fields of Philosophy, Science and the Arts, as proposed by the method of complexity of Edgar Morin. We also seek to create moments of suspension (as Husserl's epoché) that enabled to articulate such knowledge. We found in the Arts a fruitful investigation area of the flux, especially in the field of Media Arts, which, by appropriating media in their art making, anticipates aesthetic uses that later form the Communication itself, in a mediatic becoming of the Arts, as pointed by Ivana Bentes. The chosen works are constituted as installations that invite us to walk through and immerse in it, leading to the development of an anthropological path (as in Durand) that is sedimented by the experience. Thus, we come to an understanding that the Aesthetic of Flux actually implies in a Flux of the Aesthetics - Aesthetics in Flux - constituted of the categories-phenomenon of Oscillation and Imaginary Topology, composed respectively of the subcategories of rhythm / hybridity and reverie / immersion. We noticed, during the study, the importance of the social dimension, the search for the other, which leads to a demand for transcending that occurs in an immanent manner (trans-immanent). This dynamic takes us, finally, back to Communication. Recognizing the manifestations of the Aesthetics in Flux, we found some recurrences and appropriations by the Communication field and its events and pointed out some paths for future research in the area, in the direction of the man-machine relation by interfaces, among other issues.
\end{abstract}

Keywords: Flux; Heraclitus; Aesthetics; Experience; Media Art; Communication 


\section{LISTA DE TABELAS E FIGURAS}

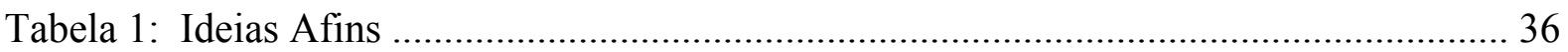

Figura 1: Exploded View (Commuters) (2011), Jim Campbell ........................................... 68

Figura 2: Exploded View (Commuters) (2011), Jim Campbell numa visão que se assemelha a uma constelação de estrelas

Figura 3: Infinity III (2012-2013), Hee Won Lee numa visão que também se assemelha a uma constelação de estrelas cuja disposição provoca a sensação de imersão ....................... 70

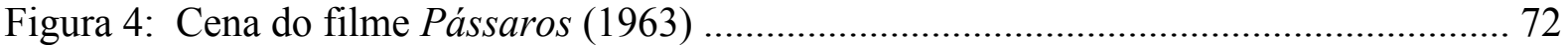

Figura 5: Mãe se abaixa para abraçar e proteger o rosto do filho ao participar da obra

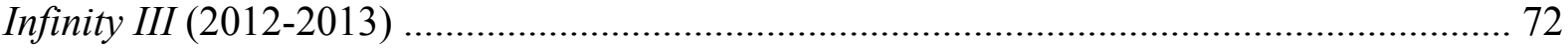

Figura 6: Vista geral da instalação Experiência de Cinema (2004), de Rosângela Rennó .....77

Figura 7: Detalhe das imagens fantasmagóricas nas projeções da obra

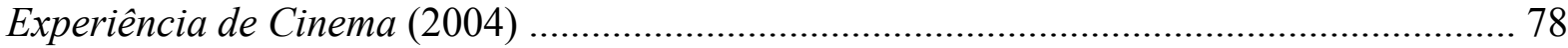

Figura 8: Frame do filme Lischtspiel, Opus I (1921), de Walter Ruttmann .......................... 82

Figura 9: Detalhe da imagem dos pássaros digitais na obra Infinity III $(2012-2013)$......... 82

gura 10: Frame do filme An Optical Poem (1938), de Oskar Fischinger .............................. 84

Figura 11: Ponto de vista da obra Exploded View (Commuters) (2011) que se assemelha ao

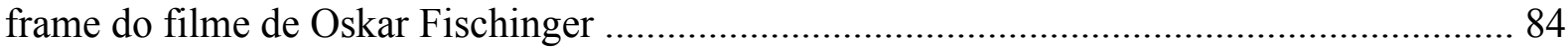

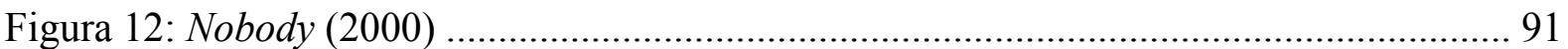

Figura 13: Dido \& Aeneas - Waldbühne (2011) ................................................................. 93

Figura 14: Homem, mulher e vinho (1658 - 1660), Johannes Vermeer .................................. 93

Figuras 15 a 19 : Sequência de imagens da instalação Il était une fois (2013) ................. 97-98

Figura 20: Face to Face IV (2013), Anthony McCall ….................................................. 105

Figura 21: Face to Face IV (2013), Anthony McCall -

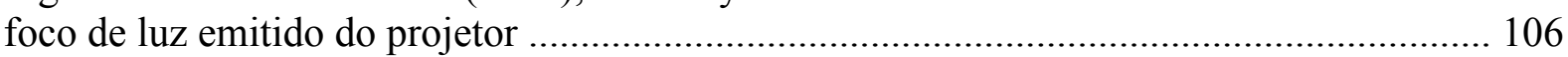

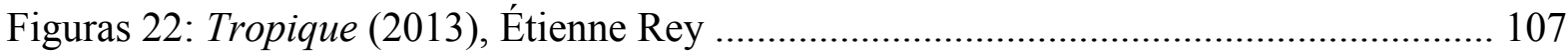

Figura 23: Um frame da imagem de um dos aparelhos cinecromáticos de Palatnik ............ 110

Figura 24: Continuel-Lumière Mobile (1960), Julio Le Parc ............................................. 111

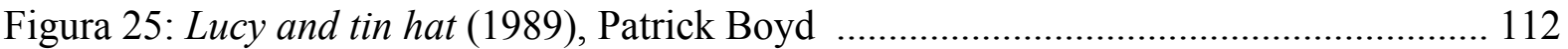

Figura 26: À sombra (2011), Katia Maciel ........................................................................ 115

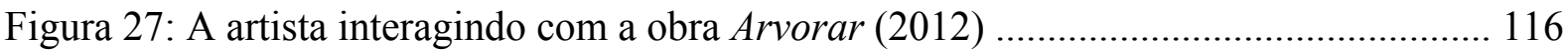

Figura 28: Circuladô (2007), André Parente …............................................................. 118 
Figura 29: Ballet Digitallique (2010), Lali Krotoszynski 120

Figura 30: Participador da obra Standing Wave (2013) que simula o bater de asas de um pássaro, junto às cordas virtuais 122

Figura 31: Participador interagindo com a obra OP_ERA: Sonic Dimension (2005) 123

Figura 32: Cena do jogo Assassin's Creed (2009) 124

Figura 33: Descendo a escada (2002), de Regina Silveira 134

Figura 34: Relatividade (1953), M.C. Escher 134

Figura 35: Um dos Penetráveis (1972) de Hélio Oiticica 137

Figura 36: Blue Penetrables (1969), Jesús Rafael Soto 137

Figura 37: The matter of time (2005), Richard Serra 138

Figura 38: Ondas: Um Dia de Nuvens Listradas Vindas do Mar (2006), Katia Maciel ...... 142

Figura 39: OP_ERA Hyperviews (2004), Rejane Cantoni e Daniela Kutschat 144

Figura 40: Nave que constitui a obra Wave UFO (1999-2002) 148

Figura 41: Interior da nave da Wave UFO (1999 - 2002)

onde se desenrola a experiência 148

Figura 42: Bubbles (2000), Wolfgang Muench e Kiyoshi Furukawa 151

Figura 43: Geopartitura (2013), MidiaLab UnB 155

Figura 44: Legible City (1988-1991), Jeffrey Shaw 157

Figura 45: Vila Lívia (20 a.C. circa) 158

Figura 46: Sala delle Prospettive (1519) 159

Figura 47: Uma das salas do Musée de l'Orangerie 160

Figura 48: Vídeo-performance VideoCriatura Imersiva (2005),

Paris, Otavio Donasci 165

Figura 49: Think (2007), The Interactive Institute 167

Figura 50: Untitled (free) (1992), Rirkrit Tiravanija 169

Figura 51: Generation 244 (2011), Scott Draves 176

Figura 52: Zee (2008), Kurt Hentschläger . 178

Figura 53: All Over (2010), Samuel Bianchini 179

Figura 54: Fractal Flowers (2008), Miguel Chevalier 180

Figuras 55 a 57: Trechos da exposição Van Gogh Experience (2014),

Fabbrica del Vapore, Milão $194-195$ 
Figura 58: O diagrama da Estética do Fluxo

Figura 59: O diagrama da Estética do Fluxo em movimento, segundo as dinâmicas da experiência da obra Standing Wave (2013) 200

Figura 60: Cena da ação de guerrilha realizada pela SCNF em Paris 205

Figura 61: Multidão reunida para o flashmob da T-Mobile em Trafalgare Square, Londres 206

Figura 62: Simulação que mostra como a interface do Google Glass é vista pelo usuário do aparelho 207 


\section{SUMÁRIO}

1. Introdução

2. Noções acerca do fluxo: investigações etimológico-filosóficas

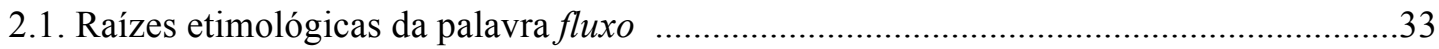

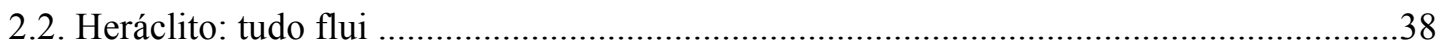

2.3. Crátilo: um diálogo entre Heráclito e Platão .................................................................43

2.4. O uno em Giordano Bruno e a relação com a dialética heraclitiana ..................................46

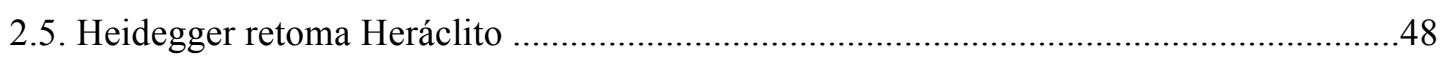

2.6. O devir heraclitiano repercute em Hegel, Nietzsche, Bergson e Deleuze ........................52

3. Oscilações da Imagem: ritmo e hibridismo na percepção do devir ………………….............66

3.1. Ritmanálise: uma dialética da mobilidade ……….....................................................74

3.2. Hibridismos: oscilações e percursos nos espaços de passagem ........................................86

3.3. Luz e sombra: atualização barroca na interação com o participador ……………........100

3.4. Entre as sensações de real e virtual: imagens-cristal no jogo entre espaço e tempo .....113

\section{Topologia imaginária: devaneio e imersão}

na experiência do corpo em espaço rizomático .126

4.1: Uma geografia rizomática do movimento .131

4.2. A experiência do corpo funda uma percepção do espaço .................................................139

4.3. Espaços do devaneio: habitar o imaginário no universo das imagens técnicas ................146

4.4. Imersão e experiência: o ser-em remete ao ser-com .....................................................156

\section{Fluxos entre Artemídia e Comunicação}

5.1. Trans-imanência: experiência e devir na ontofania das imagens técnicas .....

5.2. Linguagem poética e não-linear: o artista como designer de experiências .187

5.3. Da estética do fluxo à estética $\mathrm{em}$ fluxo .195

5.4. A estética em fluxo na Comunicação .201 


\section{INTRODUÇÃO}

Temos observado com frequência em muitos estudos recentes da área de Comunicação — principalmente aqueles relacionados às configurações da imagem e do audiovisual —, bem como em outras áreas das Ciências Sociais, o uso de uma palavra para caracterizar o que parece ser uma espécie de "sintoma" da contemporaneidade: fluxo. Tomemos como exemplo amplamente conhecido as reflexões do sociólogo Zygmunt Bauman, para quem, o mundo, em várias de suas esferas, vive atualmente num estado líquido, sempre relacionado ao seu aspecto de fluidez.

O constante uso do vocábulo, no entanto, carece de uma investigação mais profunda que leve a uma compreensão do conceito para além do senso comum e de suas implicações no âmbito das Artes e da Comunicação. Nesta pesquisa nos interessa, particularmente, buscar as origens dessa palavra para embasar o entendimento de seus desdobramentos estéticos no contemporâneo. Em um artigo sobre estética contemporânea, Priscila Arantes (In:ARANTES, SANTAELLA;2008) atenta ao fato de que estamos passando por um momento de transição de uma estética da forma a uma estética do fluxo. A partir daí, levantamos algumas perguntas: podemos falar em estética do fluxo? O que seria isso? Esses questionamentos deram o pontapé inicial para a construção do que viria a ser o nosso problema de pesquisa.

Dessa forma, voltamos nosso olhar inicialmente para as Artes, por possibilitarem a experiência estética e, assim, constituírem o próprio objeto da estética filosófica (PAREYSON;2001:10). Por acreditarmos no intenso diálogo entre arte e comunicação, somos levados a realizar um recorte ainda mais específico, buscando abordar obras de artemídia, visto que essa se mostra como uma manifestação artística que se apropria dos meios de comunicação como técnica fundante de seu fazer artístico, constituindo uma ontofania ${ }^{1}$ característica dos tempos contemporâneos, como veremos mais adiante. Para Arlindo Machado, a artemídia pode ser assim definida:

formas de expressão artística que se apropriam de recursos tecnológicos das mídias e da indústria do entretenimento em geral, ou intervêm em seus canais de difusão, para propor alternativas qualitativas. O termo compreende as experiências de diálogo, colaboração e intervenção crítica nos meios de comunicação de massa. [...]Arte com intervenção tecnológica assim como formas que acontecem em campos ainda não inteiramente mapeados, como a

\footnotetext{
${ }^{1}$ Ontofania quer dizer a maneira como os seres (ontos) se manifestam (phaïnô) (VIAL;2013:98). Ver nota de rodapé na página 110 do mesmo livro: "O termo 'ontofania' foi empregado pela primeira vez em 1952 por Mircea Eliade no sentido de 'manifestação do ser' no livro O sagrado e o profano, Paris, Gallimard, 'Idées', 1965, rééd. 'Folio essais', 1994, p. 87 e 102.”
} 
criação colaborativa em redes, as intervenções em ambientes virtuais ou semivirtuais, etc. (2010:7)

Além disso, o artista está sempre em busca de ampliar os limites, "ele cria o possível ao mesmo tempo que o real quando executa sua obra." (BERGSON;2006:118). Assim, acreditamos que as Artes - com destaque para a Artemídia, especialmente as instalações ao se apropriarem de meios de comunicação e recursos multimídia, antecipam usos e processos que posteriormente serão adotados pela própria Comunicação, num devir midiático das Artes, como aponta Ivana Bentes (In:BRUNO,FATORELLI;2006:102). Portanto, se quisermos investigar o contemporâneo e suas manifestações, encontraremos nas Artes um campo profícuo. Conforme ressalta Giorgio Agamben (2009), o contemporâneo não coincide exatamente com o tempo corrente. Pertence ao contemporâneo aquele que consegue se distanciar do atual para percebê-lo, assim como fazem os artistas.

Pelo aspecto pujante da convergência entre arte e comunicação na artemídia é que optamos, num primeiro momento, por esse recorte, na busca por compreender o que se chama de fluxo neste contexto. No entanto, ainda se faz necessário o suporte de um referencial teórico que contemple o conceito de fluxo. Por isso procuramos pesquisar, no primeiro capítulo, as raízes tanto etimológicas quanto filosóficas do termo, que se inicia na Grécia antiga, com Heráclito. Seu pensamento serve como guia ao longo do percurso que faremos em diálogo com outros filósofos como Platão, Giordano Bruno, Heidegger, Hegel, Nietzsche, Bergson e Deleuze. Assim, a partir de uma visão formada por múltiplos ângulos, poderemos abordar melhor a noção de fluxo e reconhecê-la em meio às experiências estéticas proporcionadas pelas obras de artemídia percorridas.

Essa pesquisa, aliada à percepção de nosso objeto — obras da artemídia contemporânea — nos levou a ratificar a importância de uma abordagem estética do tema. Para chegar a essa conclusão começamos por levantar, mesmo que brevemente, as transformações sofridas pelo papel do observador da obra de arte ao longo dos séculos. Passamos de uma arte, tanto na Antiguidade quanto na Idade Média, que servia como intermediária na relação com o plano metafísico (seja pelo aspecto mitológico ou divino, respectivamente), para uma arte renascentista de perspectiva humanista, mas que mantinha o observador restrito apenas a esse papel. A arte moderna quebrou muitos paradigmas no que diz respeito à representação do real e pouco avançou no quesito da participação. É com a arte contemporânea que o observador passa a interferir na obra, tornando-se parte dela, que, por sua vez, só se completa mediante essa interferência. 
O ponto de vista subjetivo, tanto do artista quanto do participador, bem como sua experiência na fruição da obra ganham destaque, consolidando uma relação de caráter estético entre a obra, aquele que a produz e a vivência dessa. Afinal, segundo Luigi Pareyson, a reflexão especulativa sobre a experiência estética engloba toda a experiência que tenha relação com o belo e com a arte: "a experiência do artista, do leitor, do crítico, do historiador, do técnico da arte e daquele que desfruta de qualquer beleza" (2001:5). Diante desse cenário, nos propomos a formular, com mais convicção, uma das hipóteses que guiarão nossos percursos investigativos e que reforça uma percepção geral do que chamamos aqui de 'sintoma' do contemporâneo: o fluxo, na contemporaneidade, não se manifesta apenas como conceito, mas como estética.

Ressaltamos que a discussão estética acerca da artemídia se faz cada vez mais necessária frente ao deslumbramento tecnológico que desvincula, na grande maioria das vezes, a discussão técnica desse âmbito. O olhar que nos interessa parte da observação de que na interação que constitui a experiência do participador com a obra (por meio de aparatos tecnológicos) existe uma produção de subjetividade que funda um dos muitos sujeitos contemporâneos, no caso, um sujeito em fluxo. A experiência da qual falamos dialoga diretamente com a noção de fluxo, a partir da concepção heraclitiana de logos ou coletividade originária, ou ainda de acordo com a ideia de devir-imperceptível que encontramos em Deleuze e Guattari (1997), como desenvolveremos no primeiro capítulo.

É uma experiência diferente daquela característica da modernidade em que há um empobrecimento do que Benjamin denominou erfahrung e cuja compreensão, grosso modo, está ligada às noções de conhecimento $\mathrm{e}$ do saber sedimentado da tradição (BENJAMIN:1994:114) — que relacionamos também ao saber popular ou ao senso comum, como propõe Maffesoli (1998) — , por vezes afluindo à memória (BENJAMIN;1994a:103). O filósofo alemão relacionou ainda a concepção de experiência à vivência, ou erlebinis, a qual remete ao cotidiano da vida moderna na cidade (tal como fez Baudelaire em seus poemas acerca da flânerie pelas ruas Paris). Acreditamos que a experiência do fluxo na contemporaneidade encontra-se entre os dois tipos de experiência propostos por Benjamin.

O flâneur contemporâneo, diferentemente do que acontecia na Paris do século XIX, não compreende a rua como interior (Ibidem:466), como seu habitat. Aí ele transita quando se desloca entre um compromisso e outro, apressado, buscando aproveitar esses pequenos lapsos de tempo para saber mais sobre o mundo e o outro que não aquele que está ao seu redor, mas alhures, ao alcance das tecnologias ubíquas e móveis, associadas à internet. Seu olhar não encontra nas banalidades do cotidiano um motivo para ater-se. Sua busca por experiência é 
consciente e envolve uma decisão prévia: uma viagem, a ida ao museu, ao cinema ou a um restaurante. Ao adentrar o museu, ele se predispõe à experiência e, ali, age como um flâneur de galerias, não das galeries parisienses, das passagens que se constituíam na paisagem preferida do andarilho das cidades, como aborda Benjamin (2007), mas como um experimentador estético ${ }^{2}$ tal como propõe Mario Costa, escolhendo seus percursos pelas instalações das obras de artemídia.

Fazemos uma ressalva, porém, quanto à noção apresentada por Costa pois, diferentemente do autor, acreditamos que a decisão lúcida pela busca de sensorialidade não anula a vivência de um sentimento que pode se fazer imagem. Como veremos no terceiro capítulo, ao nos referirmos à dinâmica do devaneio como criadora de uma topologia imaginária, os estímulos externos e visíveis, que são percebidos pelo participador no primeiro momento de contato com a obra, completam sua significação na experiência subjetiva desse participador, num diálgo com suas imagens mentais, reconfigurando a percepção — que passa a ser híbrida entre visível e invisível, graças à experiência. Para Gumbrecht "o conteúdo da experiência estética seriam os sentimentos íntimos, as impressões e as imagens produzidos pela nossa consciência - enquanto inacessíveis aos nossos mundos historicamente específicos." (GUMBRECHT In: GUIMARÃES et. al.; 2006:54).

Assim como o flâneur benjaminiano procurava relacionar a percepção à consciência por meio do transe, muitas vezes sob o uso de haxixe, o experimentador estético dos museus na contemporaneidade procura transitar entre os diferentes estados de consciência mediante o devaneio proporcionado pelo diálogo entre imagens externas e internas, numa dinâmica que o leva a encontrar a sensação de coletividade, ou de estar junto ao outro, mesmo estando só, inserindo-o num devir-imperceptível (DELEUZE, GUATTARI; 1997:73) proporcionado pela experiência.

Dessa forma, vislumbramos a possibilidade de uma experiência do fluxo na contemporaneidade que se estabeleça entre estados perceptivos conscientes e inconscientes e que englobe tanto a dimensão da erlebinis quanto a da erfahrung benjaminiana, dando destaque ao evento ou fenômeno - no caso, a experiência de percorrer as obras de artemídia. Portanto, não é de se estranhar que o aporte teórico apresentado aqui, e que será usado na investigação acerca do conceito de fluxo, terá uma abordagem fenomenológica ao objeto de estudo. Diante disso, formulamos nossa segunda hipótese: uma abordagem estética do fluxo

\footnotetext{
2 “À antiquada noção de 'personalidade artística', feita de intuição e expressão, de sentimento que se faz imagem e assim por diante, se substitui a figura do 'experimentador estético', isto é, daquele que lucidamente trabalha com a sensorialidade e com a fisiologia das máquinas imprimindo na sua pesquisa uma intencionalidade de tipo estético (COSTA;2010:140)
} 
implica em considerar a experiência como criadora de devires de um ponto de vista subjetivo.

Essa subjetividade que surge da experiência, no entanto, não é absoluta, segundo afirma Merleau-Ponty (2011:296). Ela é indivisivelmente desfeita e refeita e estabelece uma unidade entre sujeito e objeto que dura o tempo da experiência em si: "Na percepção nós não pensamos o objeto e não nos pensamos pensando-o, nós somos para o objeto e confundimonos com esse corpo que sabe mais do que nós sobre o mundo, sobre os motivos e os meios que se têm de fazer sua síntese.”(Ibidem:320).

Dessa forma, voltemos nossa atenção mais uma vez ao objeto de pesquisa: a artemídia contemporânea. A percepção da importância do sujeito na relação participador-obra bem como a observação das formas de manifestação dessa relação, aliadas ao conceito de fluxo, nos levaram a considerar um importante critério de escolha das obras que constituem nosso corpus: sua configuração como instalação. Para além do contato com uma interface plana, como a tela de um monitor, por exemplo, o participador, nesse caso, é convidado a entrar e percorrer a obra. Ele se vê cercado por ela, fazendo parte dela não apenas pela manipulação de um objeto ou meio que se constitui como uma extensão do seu corpo - a exemplo do que propunha McLuhan na década de $1960^{3}$.

O participador, então, gera uma experiência ao vivenciar a obra com o próprio corpo. São obras-instalações que constituem verdadeiros espaços de interação por meio de ambientes materiais ou imateriais - esses últimos muitas vezes construídos com recursos de projeção. A obra, aí, está sempre inacabada, pois precisa do participador para se completar, mesmo que momentaneamente, pois cada interação com um indivíduo diferente gera respostas e configurações também diferentes. Assim, justificamos também a escolha das obras que aqui constituem nosso corpus a partir dos trajetos e percursos estéticos vivenciados pelo próprio pesquisador que, como sujeito participativo de várias obras, ao sofrer a experiência estética, ressentindo a percepção do fluxo, fenomenologicamente procura realizar um exercício de suspensão e distanciamento para posterior análise.

[...] meu ato de percepção me ocupa, e me ocupa o suficiente para que eu não possa, enquanto efetivamente percebo a mesa, perceber-me percebendoa. Quando quero fazê-lo, deixo, por assim dizer, de mergulhar na mesa através de meu olhar, volto-me para mim que percebo, e me dou conta então de que minha percepção precisou atravessar certas aparências subjetivas, interpretar certas "sensações" minhas, enfim, ela aparece na perspectiva de minha história individual. É a partir do legado que tenho, secundariamente, consciência de uma atividade de ligação, quando, assumindo a atitude

\footnotetext{
${ }^{3}$ MCLUHAN, Marshall. Os meios de comunicação como extensão do homem. Cultrix, São Paulo: 2005.
} 
analítica, decomponho a percepção em qualidades e em sensações e quando, para encontrar a partir delas o objeto no qual primeiramente eu estava jogado, sou obrigado a supor um ato de síntese que não é senão a contrapartida de minha análise (MERLEAU-PONTY;2011:319)

Ao longo da pesquisa analisamos trinta e duas obras de artemídia, dentre as quais dezessete foram presencialmente experimentadas e percorridas pelo pesquisador em várias exposições organizadas em oito museus ou galerias diferentes: Centro Cultural Banco do Brasil (Oneness, Mariko Mori - Brasília, fevereiro de 2011), Instituto Itaú Cultural (Emoção art.ficial $\mid 6^{a}$ Bienal Internacional de Arte e Tecnologia — São Paulo, julho de 2012); Caixa Cultural (Dois, Kátia Maciel e André Parente — Brasília, dezembro de 2012), Espace Centquatre (Féstival Némo - Paris, dezembro 2013), Zentrum für Kunst und Medientechnologie (Sasha Waltz. Installations, Objects, Performances, Sasha Waltz Karlshue, dezembro de 2013), Galerie Martine Abucaya (Face to Face IV, Anthony McCall - Paris, dezembro de 2013), Musée d'art contemporain de Lyon (12e Biennale d'art contemporain - Lyon, dezembro de 2013) e Fabbrica del Vapore (Van Gogh Experience Milão, março de 2014). Para a compreensão dessas obras, além da experiência do percurso e vivência (erlebinis) das instalações, buscou-se dialogar com vivências e referências anteriores de outras obras de naturezas diversas e que constituem a memória (erfarung), na tentativa de abordar o objeto de estudo a partir de uma metodologia que repercutisse a noção de fluxo, como desenvolveremos adiante.

Após o percurso e observação das obras e a investigação acerca da noção de fluxo, realizada no primeiro capítulo, traçamos novos percursos que nos levaram a pensar, no segundo capítulo, sobre as manifestações visuais e perceptivas dessa obras, de forma a encontrar elementos que possam nos dar um vislumbre acerca da demonstração do fluxo por meio da experiência estética. Nos chama especial atenção a imagem projetada, impalpável, que ganha vida pela luz e que, para se impor na relação com o participador, deve também dialogar com a sombra ${ }^{4}$, criando diferentes níveis de realidade pelos quais transitamos sem barreiras. Nesse sentido, aspectos como o hibridismo e o ritmo se mostram como elementos constituintes dessa experiência estética do fluxo (ou $\mathrm{em}$ fluxo) que são regidas pela sua

\footnotetext{
${ }^{4}$ Não adentraremos os estudos relacionados à sombra, apesar de termos ciência de sua profundidade e extensão não apenas em termos visuais, mas, principalmente nos termos espiritual, mítico, psicológico e simbólico, alimentando o imaginário sobre o tema. Roberto Casati em seu livro "A descoberta da sombra"(2001), fala sobre o poder revelador da sombra: "a informação contida na sombra é um auxílio fundamental para a visão. [...] Nossa visão é tão enfeitiçada pelo claro-escuro que, se de repente nos encontrássemos num mundo sem sombras, tudo nos pareceria sem espessura, sem substância"(CASATI; 2001: 13). Em outro trecho do mesmo livro, ele diz: "a sombra é a forma visível da alma."(Ibidem:37). Para mais informações, vide: CASATI, Roberto. A descoberta da sombra. De Platão a Galileu: a história de um enigma que fascinou grandes mentes da humanidade. São Paulo: Companhia das letras, 2001)
} 
aparente oscilação e nos ligam mais especificamente a uma especulação sobre o tempo mas que, por se tratar de fluxo, não se desvincula também do espaço.

Já no terceiro capítulo somos levados a investigar mais a fundo o espaço temporalizado pela experiência, procurando desvendar a formação de topologias imaginárias e rizomáticas em que podemos habitar as imagens por meio da imersão e do devaneio, o que acaba por nos levar a uma sensação de pertencimento a algo maior que nós mesmos, conduzindo-nos à necessidade de compartilhamento, de busca pelo outro ou do estar-junto - uma coletivização da estética que ressalta seu caráter sensível, como aponta Maffesoli (1998), indicando uma mudança nas dinâmicas de transcendência. Ao invés de nos voltarmos ao divino, ao religioso ou ao espiritual, nossa necessidade de transcendência se volta, agora, a nós mesmos, à experiência estética e às manifestações do fluxo, quando nos integramos a algo externo e maior que o eu. A esse processo denominamos trans-imanência e a vislumbramos como uma dinâmica pertencente à estética do fluxo.

Dessa forma, a estética do fluxo assume seu caráter social e coletivo, por meio de uma problematização ontológica que nos mostra um sujeito contemporâneo em busca de algo maior que ele mesmo, diante das possibilidades técnicas de seu tempo. A necessidade de transcendência se realiza de forma imanente, ou seja, se estabelece na ligação com o outro por meio da experiência e do estabelecimento de laços sociais que partem do próprio sujeito. Nesse cenário, o artista se transforma num designer de experiências (como veremos no quarto capítulo), em que as obras se voltam mais ao processo e à participação do que a uma significação completa e fechada. A obra também se encontra em fluxo.

No quarto capítulo procuramos, ainda, a partir das experiências e percepções das obras, elaborar o que estamos chamando de estética do fluxo, organizando o conhecimento apurado ao longo da pesquisa, na tentativa de mostrar as categorias que compõem tal estética. Tais categorias, no entanto, não devem ser tomadas como uma fôrma ou um enquadramento que visam à estratificação, pelo contrário, devem ser compreendidas como fruto da experiência de reconhecimento de fenômenos que indicam manifestações estéticas do fluxo e, diante disso, as chamaremos de categorias-fenômeno. Essas, por sua vez, são inconstantes e variáveis, fazendo com que nosso entendimento acerca da estética do fluxo englobe também a noção de uma estética em fluxo.

Após a compreensão das configurações da estética do fluxo, identificamos que suas dinâmicas, encontradas nas obras de artemídia, repercutem também no campo da Comunicação. Assim, da mesma forma em que partimos de uma observação incipiente do constante uso da palavra fluxo nos estudos realizados atualmente na área, bem como de sua 
relação com o campo das Artes — principalmente na artemídia —, retornamos finalmente à Comunicação, reconhecendo as manifestações da estética do fluxo em ações recentes que representam as transformações ocorridas nesse âmbito após a mudança de um consumidor/receptor passivo ao prosumer $^{5}$, ou seja, um receptor participativo — processo semelhante ao ocorrido com o observador artístico. Aí encontramos os meios de comunicação aliados às redes sociais digitais exercendo um papel preponderante na efetivação dos laços sociais. Nos deparamos com propostas inovadoras de relacionamentos entre pessoas a partir de ações de experiência e de interfaces cada vez mais fluidas, assim como acontece com a apropriação desses meios e redes pela artemídia.

Portanto, diante do que foi exposto até aqui, apresentamos o objetivo geral desta pesquisa: propor uma estética do fluxo, com suas implicações, a partir do diálogo entre a noção e a experimentação fenomenológica de suas manifestações nas obras de artemídia contemporânea. A problematização de tal tarefa se norteará pela seguinte pergunta: Como as recorrências do fluxo encontradas na experiência de obras da artemídia contemporânea se articulam na constituição de uma estética do fluxo que transforma a percepção do sujeito em relação a si mesmo, ao mundo e ao outro?

Investigar os conceitos por trás da palavra fluxo para assim observar suas manifestações em obras de artemídia, e extrair daí uma estética, implica em muito mais que apenas levantar pontos de vista de teóricos e filósofos. Devemos compreendê-los para, apropriando-se deles, estabelecer um diálogo entre a teoria, o objeto e, como já propusemos aqui, a experiência do participador que vivencia a obra em questão. Pareyson (2001:4-5) destaca que a estética não pode deixar de ser filosofia, no entanto, para se constituir como indagação puramente filosófica, deve fazê-la como uma reflexão que se constrói sobre a experiência estética.

No entanto, se queremos abordar o fluxo por meio da fenomenologia, a primeira questão que se coloca seria a de como analisar algo que por si só está em constante movimento? Bergson, em seu livro O pensamento e o movente (2006), faz uma reflexão sobre como abordar a realidade fluida em que estamos inseridos. Como aplicar recortes a uma realidade sem tirá-la de sua duração em fluxo? Estamos habituados à tradição cartesiana da ciência, no entanto, permanecer restrito aos seus métodos de análise não será suficiente para a compreensão de um objeto de estudo que está em contínua mudança. Devemos pensar numa

\footnotetext{
${ }^{5}$ Termo cunhado por Alvin Toeffler em seu livro "A Terceira Onda" (1980), para representar o consumidor que também é produtor de conteúdo.
} 
forma de aliar a análise tradicional a um pensamento e uma metodologia do fluxo, a fim de entender uma estética decorrente daí.

Se optarmos por parar o movimento da realidade e das coisas para então extrair uma amostra dessa realidade, na tentativa de apreender nosso objeto, já estaremos frente a um grande obstáculo epistemológico tendo em vista que, ao isolá-lo, já interferimos sobre ele, tirando-o de seu fluxo e, impossibilitando sua compreensão na totalidade. Poderíamos, ainda, tentar olhar para o objeto a partir de um ponto de vista atual que se voltasse ao passado, supondo a realidade observada como um possível devir. No entanto, ainda assim incorreríamos no erro de congelar a realidade, tirando-a de seu movimento. E, como aponta Bergson, nossa situação presente seria percebida apenas como um rearranjo do antigo, ignorando, na verdade, a multiplicidade de possibilidades e o horizonte da novidade (2006:22).

Relembremos a metáfora de Heráclito, que toma a imagem do rio para explicar um estado de fluição das coisas. Não há como isolar uma parte do rio. Apenas podemos compreender o que é o rio a partir da experiência de entrar nele. E cada vez que o fizermos, estaremos em uma nova situação, pois tanto o rio quanto nós teremos mudado. Bergson, ao retomar o pensamento kantiano, recorda que o filósofo afirmava ser impossível apreender a coisa em si; esta escapa-nos. Para atingi-la seria necessário fazer uso de uma faculdade intuitiva que, segundo ele, não possuiríamos (2006:24). A partir daí, Bergson vai desenvolver uma reflexão acerca de como pensar o movente. Ele começa por definir o que entende por 'intuição': "Intuição, portanto, significa primeiro consciência, mas consciência imediata, visão que mal se distingue do objeto visto, conhecimento que é contato e mesmo coincidência." (Ibidem:29). Ele complementa: "A intuição é aquilo que atinge o espírito, a duração, a mudança pura." (Ibidem:31).

A percepção do objeto, portanto, — mais do que apenas observação, pois irá assumir a dimensão da experiência - não se desvincula do sujeito, repercutindo uma metodologia de abordagem fenomenológica. Assim, dando importância ao ponto de vista subjetivo, a experiência daquele que analisa também torna-se fundamental - retomemos o personagem que adentra o rio, em Heráclito. Somente dessa maneira, por meio da intuição e da experiência somos capazes de apreender as coisas, participando delas. Para Pareyson (2001:8), a filosofia e a experiência estão indissoluvelmente unidas: "condição do caráter especulativo do pensamento filosófico é não somente o levantar-se sobre a experiência para sobre ela refletir, mas também o contato com a experiência, sem o que o pensamento cairia na estéril abstração". 
Na busca por compreender a experiência como método, encontramos em Merleau-Ponty uma reflexão sobre a forma como a ciência consegue construir apenas uma aparência de subjetividade, introduzindo sensações onde a experiência mostra que existem conjuntos significativos, de forma que acaba por sujeitar o universo fenomenal a categorias que só são exigidas no universo da ciência mesma, "sem ver que o próprio do percebido é admitir a ambiguidade, o movido, é deixar-se modelar por seu contexto." (2011:33). Assim, admitimos que a organização de um conhecimento pode, sim, beneficiar-se de categorias, não com o intuito de estancá-lo, mas no sentido de tornar visível suas possíveis manifestações. Ao invés de pensar em tabelas e restrições, pensemos em rizoma, como propõe Deleuze, em que uma rede de categorias-fenômeno, como as que denominamos anteriormente, pode ser constituída de pontos que se relacionam entre si, abolindo hierarquias.

Dessa forma, a experiência constitui uma reflexão que não é absolutamente transparente, mas brota sem saber ela mesmo de onde brota "e se oferece a mim como um dom da natureza. [...] Entre mim, que analiso a percepção, e o eu que percebe, há sempre uma distância."(MERLEAU-PONTY; 2011:74). Assim, quem percebe não procura explicar essa percepção, mas coincide com a operação perceptiva para compeendê-la (Ibidem:77). Encontramos aí uma semelhança com a proposta intuitiva de Bergson, no entanto, MerleauPonty faz uma crítica ao filósofo francês, pois acredita que o campo fenomenal que aí se estabelece não constituiria um estado de consciência, uma introspecção ou uma intuição tal como proposta por Bergson:

a experiência dos fenômenos não é, como a intuição bergsoniana, a experiência de uma realidade ignorada em direção à qual não há passagem metódica - ela é a explicitação ou o esclarecimento da vida pré-científica da consciência, que é a única a dar seu sentido completo às operações da ciência, e à qual estas operações sempre reenviam. Não se trata de uma conversão irracional, trata-se de uma análise intencional. (MERLEAUPONTY;2011:94)

Para Merleau-Ponty, o erro de Bergson seria o de acreditar que o sujeito possa fundir-se ao objeto. Não encontramos um descompasso tão grande entre o pensamento dos dois filósofos. Acreditamos que a proposta bergsoniana de intuição como contato com a coisa mesma, ao invés de coincidência irracional, trata-se de um contato ingênuo com um mundo já sempre "ali", como propõe a fenomenologia (MERLEAU-PONTY;2011:1). Bergson não descarta a importância da análise, mas vincula-a à intuição para não estagnar o movimento próprio à coisa observada. De acordo com seu pensamento, aplicar o método da análise, apenas, levaria a operarmos sobre o imóvel, tirando a coisa de sua duração. De modo que da 
intuição podemos passar para a análise mas da análise não podemos passar para a intuição (2006:209) — tendo em vista que a intuição parte justamente do movimento (Ibidem:32).

Aí reside outra crítica frequente à fillosofia bergsoniana que irá se voltar à sua concepção da duração contínua. Bachelard afirma que os fenômenos da duração são construídos por ritmos que pressupõem movimento e pausas. Para ele, a filosofia de Bergson seria tão móvel que chegaria a atribuir movimento ao repouso (1963:14). O fluxo heraclitiano, sobre o qual nos aprofundaremos no primeiro capítulo, também remete a um movimento constituído de rupturas, ou para ser mais fiel ao pensamento do efésio, de uma harmonia que surge no embate entre contrários. Noção bem diferente do senso comum que aborda sua concepção de fluxo a partir de uma leitura rasa da metáfora do rio, relacionando-a meramente a um movimento incessante. Também não idealizamos o movimento dos fenômenos-obra, ou de nossos objetos de estudo, como um contínuo, mas como um fluxo que se desenrola de forma oscilante, permitindo brechas de diálogo e encontro, tornando possível sua própria composição híbrida.

Acreditamos que muito do que se atribui ao pensamento bergsoniano sobre uma duração contínua pode ser interpretado de outra forma. Deleuze (1999:22), ao apresentar o método intuitivo de Bergson, destaca uma das regras para sua aplicação, que consiste em resolver os problemas mais em função do tempo do que do espaço. Isso porque Bergson acredita que a intuição supõe a duração. No entanto, não devemos tomar um pelo outro. "A intuição é sobretudo o movimento pelo qual saímos de nossa própria duração, o movimento pelo qual nos servimos de nossa duração para afirmar e reconhecer imediatamente a existência de outras durações acima ou abaixo de nós.” (DELEUZE; 1999:23). Desde a antiguidade que se tenta compreender o movimento e a mudança pelo que não muda e não se move, por uma paralisação do fluxo. Sobre tal questão, Bergson afirma:

Para compreender o fluxo devemos resgatar a mudança e a duração em sua mobilidade original através da revivificação da nossa capacidade de perceber, através de um prolongamento dado à intuição por almas privilegiadas restabeleceríamos a continuidade no conjunto de nossos conhecimentos. (2006a:163)

Ora, não podemos relacionar, aí, a proposta de superposição de durações a uma duração maior que abarque as demais durações e considere cada sobreposição temporal como uma possível ruptura dentro do contexto mais abrangente? E não poderíamos ainda associar tais rupturas sobrepositivas à suspensão fenomenológica (epoché), conforme o pensamento de Husserl (2006:79-80), abalando a noção de um sujeito separado do objeto mas priorizando a 
relação entre eles? É a suspensão que permite o distanciamento necessário para a análise que se segue à experiência no momento da percepção, aliada à intuição.

Maffesoli (1998:130) não acredita que a intuição seja de caráter meramente pessoal. Para o sociólogo, ela participa mesmo de um inconsciente coletivo oriundo de um tipo de sedimentação da experiência ancestral, constituindo uma espécie de "saber incorporado"que em cada grupo social e em cada indivíduo se forma sem que a ela demos tanta atenção. Assim, ela enraíza-se profundamente na própria coisa, nutrindo-se dela (Ibidem:133), tal como propõe Bergson. Ele ainda afirma que a reflexão sobre a intuição estaria ligada a uma prática social constituída sobre a aisthesis $^{6}$, no seu sentido mais simples de uma experiência em que se vibra em comum, sentindo em uníssono; um experimentar coletivamente: "coisas que permitem a cada um, movido pelo ideal comunitário, sentir-se deste mundo e em casa neste mundo.” (Ibidem:137). Essa noção também pode ser encontrada em Heráclito, em que a intuição está no próprio fundamento do logos (compreendido como coletividade, como veremos mais adiante) e pode configurar um pensamento de união entre os opostos, pensamento também caro ao filósofo grego.

Dessa forma, não encontramos uma contradição entre a postura intuitiva e a análise fenomenológica que pressupõe a experiência e um distanciamento entre sujeito e objeto por meio da suspensão. Heidegger (2002) concebia esse distanciamento pela observação de uma imagem da coisa. Para o filósofo alemão, quando falamos da imagem de algo quer dizer que o próprio objeto está diante de nós. Nesse processo devemos, portanto, compreender o mundo como imagem, ou seja, olhar o mundo de fora, ao mesmo tempo em que fazemos parte dele - aí somos sujeito e objeto concomitantemente. Ao colocarmos o próprio mundo diante de nós, por meio de sua representação imagética, podemos contemplá-lo segundo o princípio da mundividência, que para o filósofo significa "intuição de vida" (Ibidem:117), e pressupõe a vivência do observador como sujeito em meio àquilo que se propõe observar.

Nesta pesquisa procuramos trabalhar sempre na relação entre diferentes abordagens, de maneira a conseguirmos um estado de suspensão momentânea de alguns processos, colocando-os entre parênteses enquanto levantamos outros elementos, sejam eles conceituais, perceptivo-descritivos ou subjetivos, para depois retomá-los e estabelecer um diálogo segundo múltiplos pontos de vista. Consideramos que essa seja uma forma pertinente de contemplar um objeto em constante mutação: um método que encontra repercussão também no pensamento da complexidade.

\footnotetext{
${ }^{6}$ Aisthesis, segundo Maria Beatriz de Medeiros significa estética no sentido grego do termo; é um estar aberto ao mundo, aberto ao sensível do mundo e deixar-se contaminar. (MEDEIROS, 2005, p.13)
} 
Ao discorrer sobre o tema, Edgar Morin atenta para alguns perigos em que podemos incorrer. Damos destaque aqui para alguns deles. O primeiro se refere à possibilidade de cairmos numa redução simplista que apenas crie categorizações, colocando cada elemento em sua respectiva caixa, dando a falsa sensação de multiplicidade e transdisciplinariedade. "É preciso um paradigma de complexidade que, ao mesmo tempo, separe e associe, que conceba os níveis de emergência da realidade sem os reduzir às unidades elementares e às leis gerais." (2005:138). Devemos, portanto, buscar uma organização que constitua, ao mesmo tempo, uma unidade e uma multiplicidade: "A complexidade lógica de unitas multiplex nos pede para não transformarmos o múltiplo em um, nem o um em múltiplo.” (MORIN; 2005:180). O princípio da multiplicidade dá sinais de servir à abordagem de um objeto em fluxo. Veremos em Heráclito e em Giordano Bruno o pensamento relativo ao todo-um ou ao uno, no qual se supõe uma relação entre todas as coisas, formando uma unidade a partir de sua própria multiplicidade - e essa é a condição sine qua non dessa unidade. Num estado de fluxo esse é o modo de ser das coisas: partes que formam um todo.

Nesse sentido, Morin nos apresenta o princípio hologramático. Ele é particularmente interessante por se apoiar metaforicamente sobre uma imagem muitas vezes usada pela artemídia: a imagem holográfica. No holograma cada um de seus pontos incluem quase toda a informação do conjunto que ele representa. Temos, portanto, uma situação em que não só a parte está no todo, mas o todo está na parte. Ao princípio hologramático, Morin acrescenta o princípio dialógico pois acredita que somente mediante o diálogo conseguimos realizar uma abordagem multidimensional, num trabalho de tessitura de contrários que formam um todo complexo ${ }^{7}$.

Ao falar em 'todo complexo' devemos, mais uma vez, ter cautela, pois pensar dentro de uma lógica de manutenção das relações todo/partes, uno/diverso também pode resultar num reducionismo que simplifica o pensamento. Este é o grande desafio da complexidade: trata-se de um sistema aberto e, por isso, passível de constantes mudanças — tal qual o fluxo. Justamente por se constituir num sistema aberto, devemos pressupor que "o progresso não está necessariamente na constituição de totalidades cada vez mais amplas; pode estar, pelo contrário, nas liberdades e independências de pequenas unidades.” (MORIN; 2005:262).

Diante disso, retomamos nossa proposta de trabalhar na relação entre diferentes abordagens que, aqui, constituirão um tripé teórico metodológico, construído, por sua vez, no trânsito entre os campos da Ciência, das Artes e da Filosofia - assim como também propõe

\footnotetext{
${ }^{7}$ Complexus = aquilo que é "tecido junto" (MORIN; 2005:215)
} 
Morin. Nesse caso, para não cairmos nas armadilhas reducionistas de uma má aplicação do método complexo, vamos procurar olhar para essa relação pela intuição, contemplando o ponto de vista subjetivo não apenas do pesquisador, mas do artista e, também, do participador da obra de arte, quando possível, tendo em mente que essa postura mantém a análise aberta e sujeita a constantes mudanças, de acordo com as características próprias de cada obra que constitui nosso corpus.

Para efeitos do esforço metodológico que realizaremos aqui, ressaltamos que a escolha por um método complexo, apoiado na relação entre ciência, arte e filosofia, não pretende constituir uma solução, a primeira vista confortável, que englobaria múltiplos pontos de vista capazes de contemplar o objeto como um todo, pelo contrário. Por ser aberto, concebemos o objeto como estando em constante mudança e nossa análise apoiada na intuição apenas como uma possibilidade de compreensão e abordagem desse objeto no fluxo de sua existência.

Chamamos aqui de intuição a simpatia pela qual nos transportamos para o interior de um objeto para coincidir com aquilo que ele tem de único e, por conseguinte, de inexprimível. Pelo contrário, a análise é a operação que reconduz o objeto a elementos já conhecidos, isto é, a elementos comuns a esse objeto e a outros. Analisar consiste portanto em exprimir uma coisa em função daquilo que não é ela. Toda análise é assim uma tradução, um desenvolvimento em símbolos, uma representação tomada de pontos de vista sucessivos a partir dos quais anotamos a cada vez um novo contato entre o objeto novo, que estudamos, e outros, que acreditamos já conhecer. Em seu desejo eternamente insaciado de abarcar o objeto que ela está condenada a rodear, a análise multiplica incessantemente os pontos de vista para completar a representação sempre incompleta, varia sem descanso os símbolos para perfazer a tradução sempre imperfeita. Prolonga-se portanto ao infinito. Mas a intuição, se ela é possível, é um ato simples. (BERGSON; 2006:187)

A citação de Bergson nos dá algumas pistas que podem guiar as tentativas de empregar a intuição em nossa metodologia, ao mesmo tempo em que nos impõe outro desafio: a intuição, se ela é possível, é um ato simples. Retomemos aqui o pensamento complexo que, em suas diretrizes, não se opõe ao simples, mas à simplificação. Tal qual a intuição, a complexidade, se mantida aberta às múltiplas possibilidades de abordagem de um objeto, procurando compreendê-lo não a partir de um ponto de vista único, mas da relação que se estabelece entre essas diferentes abordagens, tende a se desenrolar de maneira simples e fluida. Assim, segundo Bergson, no texto citado, a intuição nos transporta para dentro do objeto para coincidir com ele, por meio da sua experiência por parte de um sujeito.

Nesse caso específico da relação com a obra de arte, para compreendê-la de forma abrangente, devemos também examinar os recursos tecnológicos e comunicacionais que 
tornam possível essa interação com o participador, criando uma ontofania específica da contemporaneidade. E para conseguirmos ligar as etapas dessa relação, que se transforma continuamente, recorreremos também à filosofia. Somente assim, unindo a experiência da fruição artística, os aspectos tecnológicos e científicos da obra que constituem a interação e o aporte filosófico, acreditamos que seja possível perceber um objeto em fluxo.

A dificuldade em registrar uma análise perceptiva realizada com esse embasamento, principalmente no que diz respeito a deixar contribuições para pesquisas futuras, nos remete mais uma vez à ciência que, por sua vez, possibilita que partamos de um arranjo de um estado de coisas (em fluxo, apreendidas pela intuição) para um rearranjo delas (recortadas, apreendidas pela análise). Daí a importância da relação entre arte, filosofia e ciência. Segundo Bergson, a arte dilata nossa percepção, mas não nos faz ultrapassar o presente. Para isso precisamos da relação com a filosofia; para conferi-la profundidade (2006:181). Portanto, desde o momento em que recortamos nosso corpus acreditamos que as artes constituiriam uma área de conhecimento própícia para investigar o sintoma contemporâneo do fluxo. Esse, sem dúvida, é um recorte que, em um primeiro momento, se realizou pela intuição, pois foi vivenciando a experiência de interagir com tais obras que entramos em contato com a sensação de fluxo. Só depois, com análises dos aspectos tecnológicos e científicos, bem como com leituras de filósofos, relacionando-os às sensações do fruir da obra como participador é que ratificamos nosso recorte. E assim, percorremos o caminho proposto por Bergson, que parte da intuição à análise e que aqui se realizará na relação entre os três campos já mencionados (filosofia, arte e ciência). Eis, adiante, como pretendemos articulá-los.

A interlocução com o campo artístico é intrínseca ao próprio objeto. Acreditamos que é no campo das Artes, por motivos já manifestados anteriormente, que conseguiremos compreender o que é o fluxo no contemporâneo e desdobrar essa compreensão na elaboração de uma estética. Além disso, também já mencionamos o fato de os artistas e as Artes nos despertarem percepções que ainda não somos capazes de ver, o que faz com que a artemídia — no caso desta pesquisa —, ao se apropriar de recursos multimídia, antecipe usos que, mais tarde, possivelmente serão comuns aos meios de comunicação.

As Artes têm se aproximado não apenas da Comunicação, mas da tecnologia e da ciência, de modo geral. Essa tendência aproxima artistas, engenheiros e cientistas, anteriormente isolados em suas áreas. A relação que se estabelece entre arte e ciência tem formado equipes de trabalhos transdisciplinares para produzir conhecimento por meio do diálogo. Podemos citar o exemplo da obra Caracolomobile (2010) de Tania Fraga, sobre a qual nos voltaremos no segundo capítulo, cuja execução envolveu estudos voltados às áreas da Biologia e da 
Geometria, para alcançar o movimento orgânico da máquina desenvolvida. Também foi realizada uma pesquisa de materiais, chegando ao uso do titânio, para conseguir uma estrutura leve, flexível e resistente, além da programação computacional para fazer todo o sistema funcionar. Outra obra também de Tania Fraga, Superfícies Estimuláveis (2004), envolveu programação computacional e tecnologia química, na busca de uma membrana de borracha que simulasse o comportamento de uma arraia. Outros artistas, dentre os quais podemos citar o brasileiro radicado nos Estados Unidos, Eduardo Kac, aproximam a botânica e a genética da artemídia, por exemplo.

Quando a artemídia tecnológica encontra um participador que interage com a obra, entramos no âmbito da experiência e, partindo dela, com a observação da apropriação de determinadas técnicas que a tornam possível, recorremos ao aporte filosófico para a compreensão dessa relação. Bergson cita como é comum encontrar filósofos e cientistas que também são artistas bem como cientistas que também são filósofos. Segundo ele, "uma filosofia verdadeiramente intuitiva realizaria a união tão desejada da metafísica e da ciência." (2006:224).

Dentre os filósofos que também são artistas, a obra de Ravaisson lhe chama particular atenção e a ela ele dedica um capítulo do livro O pensamento e o movente: "Toda a fillosofia de Ravaisson deriva dessa ideia de que a arte é uma metafísica figurada, de que a metafísica é uma reflexão sobre a arte e de que é a mesma intuição, diversamente utilizada, que faz o filósofo profundo e o grande artista." (BERGSON; 2006:272). Assim sendo, ao escolhermos o universo da arte para a seleção de nosso objeto de pesquisa, acreditamos que já partimos da dimensão intuitiva.

No campo filosófico, a discussão se desenvolverá inicialmente com uma pesquisa a partir das raízes etimológicas da palavra fluxo, ligando-a às noções desenvolvidas por filósofos que trataram do tema desde a antiguidade, buscando compreender o conceito. A pesquisa contemplou a etimologia nas línguas portuguesa e latina, inicialmente e, após o contato com Heráclito, principalmente, fomos levados às raízes gregas do termo. Dentre os filósofos que pensaram o movimento e, consequentemente, o fluxo ao longo dos séculos, nos voltamos mais especificamente às reflexões de Heráclito de Éfeso (535 a.C. - 475 a.C.) e como ela repercutiu em outros filósofos, principalmente em Platão (2001); Bruno (1998); Heidegger (1998, 2008, 2008a); Hegel (2011); Nietzsche (1999, 2007, 2012); Bergson (2006, 2006a, 2010), Deleuze e Guattari $(1995,1997)$ e Deleuze $(2007,2009)$.

O importante aqui é termos sempre a cautela de não recorrer à filosofia como única guardiã de uma suposta verdade acerca dos conceitos. Não podemos deixar de lado a 
dimensão da intuição. E se, como já afirmamos antes, a intuição atinge o espírito, ela também está ligada à metafísica. Para Bergson, a metafísica, para ser uma ocupação séria, deve transcender os conceitos, chegando à intuição.

Decerto, os conceitos são-lhe indispensáveis, pois todas as outras ciências
trabalham normalmente com conceitos e a metafísica não poderia passar-se
das outras ciências. Mas ela só é propriamente ela mesma quando ultrapassa
o conceito, ou pelo menos se liberta dos conceitos rígidos e já prontos para
criar conceitos bem diferentes daqueles que normalmente manejamos, quero
dizer, para criar representações flexíveis, móveis, quase fluidas, sempre
prontas a se moldarem pelas formas fugidias da intuição. (2005:194)

Bergson nos aponta alguns caminhos para seguir nessa difícil tarefa. Segundo ele, como os meios de expressão que temos são os conceitos e a imagem, devemos nos voltar à imagem quando vamos em direção à intuição (2006:138). Assim, vejamos como nos organizaremos ao longo da pesquisa. Partiremos de uma compreensão da noção de fluxo segundo um levantamento etimológico e filosófico que formará a base conceitual para o reconhecimento da sensação de fluxo na experiência das obras de artemídia contemporânea, por meio de uma postura intuitiva. Num segundo momento procuraremos retomar as vivências subjetivas, numa observação posterior das imagens dessas obras e experiências, principalmente por meio de vídeos, destacando os aspectos perceptivos que levaram ao despertar das sensações, realizando uma descrição da experiência em si. Essa descrição é, também em sua constituição, fluida e articula a imagem dessas percepções a outras imagens, num processo que dialoga com o imaginário, trazendo outras experiências e vivências relacionadas a obras e imagens diversas, sejam elas pertencentes ou não ao âmbito da artemídia.

Tal proposta se aproxima da dinâmica utilizada por Warburg na organização de seu Atlas Mnémosyne (1924 - 1929), que pretendia estabelecer um pensamento reflexivo baseado na relação de imagens com características visuais semelhantes, voltadas principalmente à representação do estilo da vida em movimento durante o período do Renascimento. Para Warburg, seu processo consistia em partir da memória e realizar tais relações numa “oscilação rítmica entre imersão na matéria e retorno à sophrosyne" (RECHT In: WARBURG:2012) 9 . Assim, ele assume a posição subjetiva do pesquisador, pois o resultado final de sua pesquisa é visual e se apresenta como uma interpretação que traz à tona memórias imagéticas de experiências e referências anteriormente vividas e consultadas, atualizadas a cada estímulo de

\footnotetext{
${ }^{8}$ Em grego: $\sigma \omega \varphi \rho \circ \sigma u ́ v \eta$. Está ligado aos conceitos de prudência e sensatez.

${ }^{9}$ Tradução realizada pela autora. Quando não houver tradução para português disponível, as traduções serão realizadas pela autora.
} 
uma nova imagem, de acordo com a temática condutora do processo. Dessa forma, ele admite a multiplicidade e ambiguidade das relações possíveis.

\begin{abstract}
Warburg tenta integrar a instância de percepção e de conhecimento, a instância que sistematiza e anima as imagens, quer dizer, o espectador e, em particular, o pesquisador, como sujeito dessa dinâmica. Num ato de assimilação insensível, o sujeito registra os movimentos do "mundo-objeto"e os incorpora pelo seu próprio movimento corporal no espaço discursivo. [...] O sujeito da percepção se coloca em movimento. (SIEREK;2009:28)
\end{abstract}

Tal descrição, portanto, leva em conta também o processo de comparação que para Warburg se constitui numa atividade decisiva na forma como circulam as imagens, colocando o mundo em movimento: "Aquele que compara deixa seu olhar correr de uma coisa à outra, pode ser mesmo que se coloque a si próprio em movimento enquanto autor da comparação, pois ele relativiza ainda sua própria posição e sua relação com as imagens." (SIEREK;2007:50). A imagem aí, inicialmente se comporta de forma mimética, projetando uma espécie de duplo de seu referente inicial, "é o que Warburg chama de reflexo real concreto." (Ibidem:43). No entanto, essa etapa seria apenas o trampolim para o movimento de impulsão energética, que libera a imagem de uma relação estreita, excedendo a pura visibilidade e inserindo-se numa dinâmica de ordem simbólica. Aí daria-se o distanciamento, necessário ao processo de análise como vimos acima na proposta de vários pensadores.

Para Warburg, o elemento dominante em suas descrições são as paradas ou o ponto de ruptura das obras. "Seu pensamento se apoia sobre as mudanças de posição bruscas, assim como ela se inspira na técnica disruptiva dos aparelhos óticos que apareceram à sua época: as máquinas que produzem imagens se tornam lugares de memória." (SIEREK;2007:30). E diante do reconhecimento da importância do aparelho nesse processo de diálogo entre homem, mundo e imagem é que propomos a articulação com o campo científico, no sentido de fazer dialogar a filosofia com a experiência, como propõe Pareyson acerca do pensamento estético.

Acreditamos, portanto, que a descrição baseada na percepção e na experiência, aliada à comparação imagético-imaginária, nos permitirá realizar tal interlocução bem como relacionar o campo da Arte ao da Comunicação. Procuraremos abordar como os meios e recursos técnicos e tecnológicos utilizados no processo configuram a percepção e as possibilidades de criação de mundos nos quais se desenrolam vários dos papéis do sujeito participador. Maffesoli (1998:120) ressalta que a descrição como método "trata de buscar a significação de um fenômeno em vez de estar focalizado sobre a descoberta das explicações causais", sendo uma boa maneira de perceber, em profundidade, aquilo que constitui as 
especificidades. Além disso ela é colocada em evidência quando a ambiência da época tende a valorizar os aspectos estéticos no seio de uma vida social (Ibidem:127). Nesse sentido, Merleau-Ponty destaca que:

Se queremos que a reflexão conserve os "caracteres descritivos" do objeto ao qual ela se dirige e o compreenda verdadeiramente, não devemos considerá-la como o simples retorno a uma razão universal, realizá-la antecipadamente no irrefletido, devemos considerá-la como uma operação criadora que participa ela mesma da facticidade do irrefletido. É por isso que a fenomenologia é a única entre todas as filosofias a falar de um campo transcendental. Esta palavra significa que a reflexão nunca tem sob seu olhar o mundo inteiro e a pluralidade das mônadas desdobradas e objetivadas, que ela só dispõe de uma visão parcial e de uma potência limitada. (2011:95)

Assim, vemos que a descrição das percepções da experiência, nos levando às sensações despertadas, podem adquirir um caráter estético-metodológico que está ligado tanto à sociabilidade quanto à transcendência, mas no sentido de uma transcendência imanente. É, portanto, no âmbito da experiência que se desenrola nossa análise intuitiva, pois ela torna possível a internalização da transcendência: "ser uma consciência, ou, antes, ser uma experiência, é comunicar interiormente com o mundo, com o corpo e com os outros, ser com eles em lugar de estar ao lado deles.” (MERLEAU-PONTY;2011:142).

Nesse processo, o imaginário ganha uma dimensão importante, completando a experiência proposta externamente, fazendo-a ressoar internamente, num diálogo com as imagens mentais que, por sua vez, se ligam também a experiências anteriores. Podemos compreender a interferência onírica ou imaginativa como uma ruptura na sequência da realidade visível, introduzindo uma possibilidade de suspensão ou pausa, em que se abre espaço para a fruição estética da experiência, para a percepção e, posteriormente, uma análise intuitiva, assim como vimos no método warburgiano. Para John Dewey (2005:51), é justamente devido ao fato do mundo real ser uma combinação de movimentos, de rupturas e reuniões que a experiência do ser vivente é suscetível de possuir qualidades estéticas.

A experiência, para o autor (Ibidem:60), é o resultado e a recompensa da interação entre um organismo e o ambiente, levando a uma transformação da interação em participação e comunicação, como acreditamos também ser característico no caso de uma experiência do fluxo. Esse ambiente, portanto, segue o ritmo da experiência subjetiva estabelecendo uma relação de interferência recíproca em que os elementos fundantes da estética - tempo e espaço - se hibridizam e não sabemos mais se é o tempo que se espacializa ou o espaço que se temporaliza, dinâmica que se intensifica ainda mais quando levamos em conta a interlocução com a parcela imaginativa e mental dessas mesmas experiências: "como cada 
experiência é constituída pela interação entre 'sujeito' e 'objeto', entre um eu e seu mundo, ela não é, ela mesma, nem simplesmente física nem simplesmente mental e pouco importa saber qual dos dois fatores predomina." (DEWEY;2005:403).

Também assim se dá na vivência das obras de artemídia que constituem nosso objeto de pesquisa. A percepção do ambiente ao redor, ou do espaço, não depende apenas de uma apreensão de seus aspectos físicos e visíveis. No decorrer da experiência, as sensações despertadas levam a uma complementação das imagens externas, através do estímulo à relação com as imagens mentais, tão particulares e subjetivas, mutáveis a cada nova vivência de um participador. É nesse contexto que acreditamos se constituir uma topologia imaginária rizomática e que se ergue a partir da imersão do participador na obra-instalação que o envolve, levando aos estados de devaneio que desencadeiam a parcela mental da experiência: “À diferença da máquina, a obra de arte não resulta somente da imaginação, ela opera no plano da imaginação e não naquele das existências físicas. Ela tem por objetivo concentrar e desenvolver uma experiência imediata.”(DEWEY;2005:443). É a visão imaginativa que constitui, para o autor norte-americano, o poder que unifica todos os componentes do conteúdo de uma obra de arte e dá forma a uma totalidade diversificada (Ibidem:445).

Assim, após definir como serão articulados cada campo de nosso tripé teórico metodológico, retomamos nosso percurso: partiremos da experiência da obra para, posteriormente, retomando a memória da experiência por meio de imagens e vídeos, seguir com a descrição imagético-comparativa das percepções e sensações vivenciadas bem como do aporte técnico, comunicacional e tecnológico, em diálogo também com a esfera imaginativa, buscando as manifestações da noção de fluxo conforme levantaremos na pesquisa etimológico-filosófica. Dessa maneira, acreditamos que poderemos realizar uma análise fenomenológica e intuitiva do objeto que permita abarcá-lo do ponto de vista estético, levando em conta relações que abrangem o sujeito, a coletividade e as dimensões do espaço e do tempo. Nos guiaremos pelos princípios da complexidade, procurando articular os campos artístico, filosófico e científico de modo a "abraçar" o fluxo como um movimento inconstante e tensionado, ao mesmo tempo em que fazemos parte dele. Esperamos assim conseguir compreender como se engendra uma estética do fluxo na contemporaneidade, traçando um rizoma constituído pelas categorias-fenômeno que aí transitam. Além disso, procuraremos investigar quais são suas implicações tanto na artemídia, na qual buscaremos nossas experiências e percepções iniciais para, então, retornarmos à comunicação, em que os laços sociais fortalecem a dimensão social e coletiva dessa estética, interferindo na percepção do próprio sujeito e do mundo que o cerca. 
2.

\section{Noções acerca do fluxo: investigações etimológico-filosóficas}

\subsection{Raízes etimológicas da palavra fluxo}

Se pretendemos compreender o fluxo a partir de uma perspectiva estética, faz-se necessário investigar essa noção a partir das aparições do termo na história do pensamento. Apenas a partir de uma familiaridade com o conceito de fluxo poderemos reconhecê-lo nas experiências junto às obras de artemídia contemporânea relacionando-as à percepção e ao despertar de sensações durante o processo.

Segundo Flusser (2007), é por meio da língua que transformamos os dados brutos que recebemos do mundo que nos cerca por meio dos sentidos, e criamos a realidade. Esse processo se dá, inicialmente, pela língua falada e, posteriormente, pela língua escrita. Entendendo as palavras como metáforas, Flusser acredita que é por intermédio delas, em suas mais diversas aplicações, que se torna possível compreender a concomitância de diferentes níveis ontológicos, como o real, o imaginário e o ideal e, assim, alcançar um vislumbre da realidade. Em verdade, ao procurar algo além da língua, Flusser acredita que as palavras nos levam ao nda $^{10}$, ou a uma realidade em constante movimento e, portanto, fluida (FLUSSER; 2007:14-15).

A língua escrita, então, nos permite, momentaneamente e subjetivamente, tangenciar, com palavras-metáforas, as sensações obtidas no contato com a realidade, nos diferentes níveis ontológicos em que a experimentamos. Assim, a pesquisa etimológica que realizamos aqui procura seguir a perspectiva fenomenológica proposta por Flusser acerca da linguagem, ao investigar não apenas os significados e origens da palavra fluxo, mas também percorrer seus afluentes por meio da abordagem de ideias a ela associadas. Essa pesquisa, relacionada às noções filosóficas que abrangem o termo, nos permite chegar a uma maior compreensão da palavra, na forma como ela se faz sentir e aplicar em sua vivência, ou seja, como é percebida esteticamente. Nossas buscas se dirigem, inicialmente, às raízes portuguesas do vocábulo que, por sua vez, nos levam às raízes latinas e, ao ingressarmos na investigação filosófica, também às raízes gregas.

\footnotetext{
${ }^{10}$ Bergson e Hegel (de maneira mais explícita) também adentram o nada ao falar sobre uma realidade em constante devir — noção que se relaciona à ideia de fluxo e que abordaremos no pensamento de outros filósofos mais adiante neste capítulo.
} 
Ao procurar o significado de fluxo em dicionários de língua portuguesa ${ }^{11}$ notamos, inicialmente, que muitas das significações estão ligadas a verbos e ações que indicam movimento ou estão ligados a estas ideias: ato ou modo de fluir; curso de fluido; movimento contínuo que se repete no tempo; corrente; vazão, entre outros. Ainda nesse sentido, encontramos versões da palavra como adjetivo, significando algo transitório ou passageiro.

Outra semelhança que nos chama atenção entre o verbete em diferentes dicionários de português é a relação com o elemento água em suas manifestações naturais: rios, ondas, marés, enchentes. Seguindo essa ideia, também encontramos uma ligação com aspectos líquidos em geral, principalmente em movimento: escorrimento ou curso de líquido; afluxo de um líquido; corrimento ou descarga líquida, entre outros. Bachelard, em seu livro A água e os sonhos (1997), investiga o imaginário poético acerca da água. Segundo ele, o rio é capaz de nos dar verdadeiras lições de lirismo.

Para mostrar bem a unidade vocal da poesia da água, vamos desenvolver imediatamente um paradoxo extremo: a água é a senhora da linguagem fluida, da linguagem sem brusquidão, da linguagem contínua, da linguagem que abranda o ritmo, que proporciona uma matéria uniforme a ritmos diferentes. Portanto, não hesitaremos em dar seu pleno sentido à expressão que fala da qualidade de uma poesia fluida e animada, de uma poesia que se escoa da fonte. (1997:193)

Existe, portanto, algo de poético e fundamental no imaginário do elemento água, assim como na ideia de fluxo, como se as duas noções se ligassem indistintamente. A dimensão fundamental da água e do fluxo ganha ainda mais força se pensarmos a relação vital do homem com a água, a começar pelo fato do elemento constituir mais da metade do corpo humano. A ideia de fluxo aparece, em várias ocasiões, também ligada aos líquidos corporais - sangue (menstrual, principalmente), esperma e corrimentos intestinais e inflamatórios tanto de uma forma que represente geração de vida quanto de uma forma mórbida, associada a doenças e excrementos.

O líquido e o fluido se mostram proeminentes ao tratar do termo fluxo; e a ligação com aspectos viscerais do corpo nos remetem à própria origem biológica do ser humano. Surgimos em ambiente fluido e nele permanecemos, imersos em líquido, durante todo o período prénatal. O estabelecimento de nossa primeira relação com outro ser, ainda no útero materno, se dá pelo fluxo de sangue entre mãe e filho mediado pela placenta, como observa Peter Sloterdijk em seu livro Esferas I. Microsferologia. (Bolhas) (2009). Ele afirma que o fluxo de

\footnotetext{
${ }^{11}$ Foram consultados os seguintes dicionários: Aurélio (FERREIRA; 2010), Michaelis (WEISZFLOG; 2004) e HOUAISS (HOUAISS; 2009).
} 
sangue faz dos dois corpos um só e se constitui no primiero medium material entre indivíduos (2009:274). Parte dos encontros afetivos mais primitivos na vivência de um ser humano, ainda na fase de gestação, é experimentada por meio de presenças sensoriais líquidas em um estado de flutuação: "Como precursos do que mais tarde se chamará realidade se apresenta aqui um reino intermédio fluidal." (SLOTERDIJK; 2009:273).

A noção de flutuação é encontrada nas raízes latinas ${ }^{12}$ da palavra fluxo — em latim, fluxus. Esse vocábulo pode ter duas origens: partindo de fluo, seus significados giram em torno, principalmente, das noções de liquidez, frouxidão, incerteza e instabilidade. Já a partir da origem fluere, os significados se voltam às noções de corrente de água, corrimento de sangue e soltura do ventre. No entanto, Cunha (2010:297) nos mostra que a palavra fluxo pode ter outras raízes latinas, tais como: flucticǒla $^{13}$ (flutícola), fluctigěnus ${ }^{14}$ (flutígeno), fluctuātǐō $^{15}$ (flutuação), fluctuans ${ }^{16}$ (flutuante), fluctuāre ${ }^{17}$ (flutuar), fluxǐo-onis ${ }^{18}$ (fluxão). Essas raízes reforçam alguns significados já atribuídos às origens de fluxus, que se relacionam principalmente ao elemento água e suas manifestações na natureza - contemplando seu movimento — bem como aos fluidos corporais.

Um fato que nos pareceu interessante durante a pesquisa é que o vocábulo flúor já se documenta, a partir do século XVIII, no sentido de 'fluxo, corrimento' (CUNHA; 2010:296). Sua raiz latina é flǔor-ōris, que tem suas origens em fluere e significados ligados a: corrimento, fluxo, curso, corrente, onda, soltura do ventre, diarreia, caganeira, corrimento de humores, catarro, entre outros (SARAIVA; 2006:495). A palavra ainda está relacionada à fluorescência e fluorescente (do francês fluorescence e fluorescente). Essa ligação um pouco distante entre fluorescência e fluxo chama atenção justamente quando pensamos nas formas de manifestação das obras da artemídia contemporânea, muitas vezes impalpável, devido à utilização de recursos luminosos de projeção, por exemplo.

Todos esses significados que encontramos ligados à palavra fluxo, tanto em português quanto em latim, também acabam por remeter a ideias afins ${ }^{19}$. Apesar de fascinante, tal busca pode resultar num longo ciclo de associações possíveis que se seguem umas às outras,

\footnotetext{
${ }^{12}$ Dicionário Latino-Português (SARAIVA; 2006:495)

${ }^{13}$ Que habita no meio das ondas (SARAIVA; 2006:494)

${ }^{14}$ Gerado nas ondas (Ibidem:idem)

${ }^{15}$ Agitação, tremura (Ibidem:idem)

${ }^{16}$ Ved. Fluctuo: Estar agitado, alvorotado (o mar); ser levado pelas ondas, flutuar, andar à tona d'água, boiar, entre outros (Ibidem:idem)

${ }_{17}^{17}$ Mesmo significado de fluctuo

${ }^{18}$ (de fluere). Corrimento, fluxo. Fluxo de sangue pelo nariz. Fluxo de ventre, soltura, caganeira, diarreia. Fluxo de sangue, hemorragia. (SARAIVA; 2006:495)

${ }^{19}$ Procuramos levantar essas ideias por meio de consulta ao Dicionário Analógico da Língua Portuguesa (2010), de Francisco Ferreira dos Santos Azevedo.
} 
principalmente se quiséssemos contemplar todos os significados existentes. Assim, optamos por nos ater às relações levantadas apenas a partir da palavra fluxo. Azevedo (2010) lista, nesse caso, as seguintes ideias afins: de Aumento (2010:16), de Transitoriedade (Ibidem:41), de Conversão (Ibidem:54), de Substituição (Ibidem:55), de Liquefação (Ibidem:129), de Rio (Ibidem:132), de Pensamento (Ibidem:183), de Suficiência (Ibidem:282) e de Regozijo (Ibidem:395).

$\mathrm{O}$ autor organizou as ideias em seu dicionário segundo uma hierarquia que as agrupa primeiramente em seis classes $^{20}$. Dentro de cada classe existem divisões (24, no total), contendo várias subdivisões (algumas com desdobramentos) que, por sua vez, englobam os grupos - constituídos pelos próprios conceitos/ideias (mil, no total). Por fim, para cada palavra, ele aborda a questão da neutralidade, ou seja, se existe um conceito antagônico ou se a palavra é considerada neutra. Abaixo esboçamos um quadro que mostra a classificação aplicada às ideias afins citadas acima.

\begin{tabular}{|l|l|l|l|l|}
\hline IDEIAS & CLASSE & DIVISÃO & $\begin{array}{l}\text { SUBDIVISÕES } \\
\text { Ddesdobramentos }\end{array}$ & $\begin{array}{l}\text { ANTAGONISMO } \\
\text { OU } \\
\text { NEUTRALIDADE }\end{array}$ \\
\hline Aumento & $\begin{array}{l}\text { Relações } \\
\text { Abstratas }\end{array}$ & Quantidade & $\begin{array}{l}\text { Comparativa } \\
\text { Variação de } \\
\text { Quantidade }\end{array}$ & $\begin{array}{l}\text { Antagônico: } \\
\text { Diminuição }\end{array}$ \\
\hline Transitoriedade & $\begin{array}{l}\text { Relações } \\
\text { Abstratas }\end{array}$ & Tempo & Absoluto & $\begin{array}{l}\text { Antagônico: } \\
\text { Diuturnidade }\end{array}$ \\
\hline Conversão & $\begin{array}{l}\text { Relações } \\
\text { Abstratas }\end{array}$ & Mudança & Simples & $\begin{array}{l}\text { Antagônico: } \\
\text { Reversão }\end{array}$ \\
\hline Substituição & $\begin{array}{l}\text { Relações } \\
\text { Abstratas }\end{array}$ & Mudança & Simples & $\begin{array}{l}\text { Antagônico: } \\
\text { Troca }\end{array}$ \\
\hline Liquefação & Matéria & $\begin{array}{l}\text { Matéria } \\
\text { Inorgânica }\end{array}$ & $\begin{array}{l}\text { Fluidos } \\
\text { Em geral }\end{array}$ & $\begin{array}{l}\text { Antagônico: } \\
\text { Vaporização }\end{array}$ \\
\hline Rio & Matéria & $\begin{array}{l}\text { Matéria } \\
\text { Inorgânica }\end{array}$ & $\begin{array}{l}\text { Fluidos } \\
\text { DEm } \\
\text { movimento }\end{array}$ & $\begin{array}{l}\text { Antagônico: } \\
\text { Vento }\end{array}$ \\
\hline Pensamento & Entendimento & $\begin{array}{l}\text { Formação } \\
\text { de Ideias }\end{array}$ & $\begin{array}{l}\text { Operações } \\
\text { Intelectuais } \\
\text { em geral }\end{array}$ & $\begin{array}{l}\text { Antagônico: } \\
\text { Incompreensão }\end{array}$ \\
\hline Suficiência & $\begin{array}{l}\text { Vontade } \\
\text { Individual }\end{array}$ & $\begin{array}{l}\text { Vontade } \\
\text { em Projeto }\end{array}$ & $\begin{array}{l}\text { Relação } \\
\text { com o fim }\end{array}$ & $\begin{array}{l}\text { Antagônico: } \\
\text { Insuficiência }\end{array}$ \\
\hline Regozijo & Afeições & $\begin{array}{l}\text { Afeições } \\
\text { Pessoais }\end{array}$ & Passivas & $\begin{array}{l}\text { Antagônico: } \\
\text { Lamentação }\end{array}$ \\
\hline
\end{tabular}

Tabela 1: Ideias Afins

Ao compararmos o significado de cada uma dessas ideias afins com as definições de fluxo nos dicionários consultados anteriormente, encontramos algumas coincidências. No caso

\footnotetext{
${ }^{20}$ Para consultar o quadro completo de classificações vide CUNHA; 2010: xiii - xxxv
} 
das noções de Aumento e Suficiência, percebemos uma relação com a ideia de grande quantidade e abundância, por exemplo. Já os substantivos Transitoriedade, Conversão e Substituição, terão pontos em comum com os significados de fluxo tomado como adjetivo, remetendo ao que é transitório, mutável e passageiro. Outro conjunto de ideias se forma na associação entre fluxo e Liquefação, levando às noções (arriscamos dizer: mais que noções, sensações) de fluidez, o que nos remete ao âmbito estético das experiências vividas nos percursos das obras de artemídia.

Na relação entre fluxo e Rio encontramos ligações com as sensações de líquido e fluido. No entanto, na definição dada por Azevedo, é acrescentada a dimensão do movimento. Esse dado nos parece importante pois na figura do rio conseguimos conciliar tantas outras noções já citadas aqui em ligação com o fluxo, principalmente aquelas que se voltam à flutuação. Notamos ainda que, na língua portuguesa, o adjetivo ligado ao substantivo rio é fluvial, cujo prefixo é o mesmo da palavra fluxo ou ainda fluidez e flutuação.

Em Heráclito, encontramos metáforas a esse respeito envolvendo a imagem do rio, como citamos anteriormete. Essas recorrências talvez reflitam um aspecto de vivência próprio da língua grega, que associa rio a fluxo, pois a grafia que designa o substantivo rio e o verbo fluir é a mesma: $\hat{\rho} \varepsilon \omega^{21}$. A palavra grega que significa fluxo é ${ }^{c} \boldsymbol{P} \varepsilon \tilde{u} \mu \alpha^{22}$, que abrange ainda os seguintes significados: derrame, corrente, rio, onda, multidão em movimento, leito do rio, corrente de lava, dessangramento, reuma.

Para o filósofo efésio apreendemos o movimento do rio (ou fluxo) apenas quando imersos nele, uma lógica que também serve para compreender a filosofia bergsoniana. Partindo de uma realidade fluida, ele acredita que a compreensão do mundo só é possível pela observação dessa mesma realidade estando inseridos em seu movimento:

pretendemos reconstituir a realidade, que é tendência e, por conseguinte, mobilidade, com os perceptos e os conceitos que têm por função imobilizála. Com paradas, por numerosas que sejam, não se fará nunca a mobilidade; ao passo que, se nos brindamos com a mobilidade, podemos dela extrair pelo pensamento tantas paradas quantas quisermos (BERGSON; 2006:220, grifo nosso).

Assim, para Bergson, o movimento carrega em si a possibilidade do exercício de um pensamento intuitivo, que levaria à filosofia: "filosofar consiste em inverter a direção habitual do trabalho do pensamento." (2006:221). Movimento (e também o fluxo) e pensamento se relacionam, portanto, por meio de situações de associação, sucessão e corrente de ideias,

\footnotetext{
${ }^{21}$ Consulta realizada no Dicionário grego-português | português-grego (BRAGA, PEREIRA;1990)

${ }^{22}$ Para tradução da palavra 'fluxo' e consulta dos significados da palavra 'Pعṽ $\mu \alpha$, vide BRAGA, PEREIRA;1990
} 
muito comuns durante um processo de brainstorm, por exemplo. A sensação aqui é a de turbilhão de ideias e acaba, de certa forma, aliando-se ainda à noção de abundância — assim como a imagem da corrente de ideias nos leva novamente a uma aproximação com a imagem do rio.

Outra ideia afim listada por Azevedo é a de Regozijo. As associações iniciais com o conceito de fluxo se fazem por uma sequência de ideias que passa pelas situações de frouxidão do riso, gargalhada estridente e gaiatice - comum a ambos - , e que nos remete ao ato de soltar-se ou a um movimento da alegria. Podemos, ainda, encontrar alguma proximidade entre esse tipo de comportamento e a ideia de exagero, por sua vez próximo à noção de abundância (também relacionada ao fluxo). Assim, um aspecto que nos chama atenção aqui é o do descontrole; de um deixar-se levar, como os objetos flutuantes levados pela correnteza de um rio.

Por fim, notamos que as relações feitas por Azevedo (2010), a partir da classificação das divisões realizada pelo autor, acabam por nos fornecer um possível caminho para a análise das obras que propomos observar. Articuladas às noções trazidas pela filosofia, e contextualizadas dentro do panorama recortado, podemos extrair dessa classificação categorias que abarcam a noção de fluxo e que podem nos servir para constituir critérios de análise de nosso objeto, tais como: tempo, movimento, materialidade, pensamento, vontade e afeição.

Veremos repercutir essa classificação ao longo da pesquisa nas investigações descritivas das obras de artemídia que, a partir de suas características perceptivas (materialidade), nos habilitarão, por meio da experiência (vontade), a encontrar manifestações da oscilação (tempo e movimento), através do ritmo e do hibridismo; e da topografia imaginária (pensamento), devido à imersão e ao devaneio, levando-nos à busca de compartilhamento e do outro (afeição). Por ora, nos voltamos ao diálogo com a filosofia acerca da noção de fluxo, posto que, se queremos abordá-la pelo viés estético, devemos reverberar a reflexão filosófica, como aponta Luigi Pareyson: “A estética é e não pode deixar de ser filosofia; melhor, só pode salvar-se na sua autonomia — sem reduzir-se à crítica, ou à poética, ou à técnica — sob condição de apresentar-se como indagação puramente filosófica” (2001:4).

\subsection{Heráclito: tudo flui}

Pouco se sabe sobre o filósofo Heráclito de Éfeso e parte dos ensinamentos que a ele atribuimos chegou até nossos dias via fragmentos, preservado em escritos de outros filósofos 
gregos. Foi por meio de Platão, em Crátilo, que se toma conhecimento do pensador mobilista do "tudo flui" em contraste com Parménides (530 a.C. - 460 a.C.), propagador das ideias do imobilismo.

A concepção do cosmos heraclitiano leva em consideração um "espaço em que pode ser contemplada a contínua transformação de tudo, a 'fluência'das coisas" (COSTA; 2005:176). Essa lógica do movimento, segundo Heráclito, se faz necessária para a própria manutenção do estado das coisas, noção que evidencia o caráter dialético de seu pensamento. Para Heráclito, o contrário é convergente e é do encontro dos contrários que surge a verdadeira harmonia: "ignoram como o divergente consigo mesmo concorda: harmonia de movimentos contrários, como do arco e da lira.” (HERÁCLITO apud HIPÓLITO In: COSTA; 2005:83).

Compreender essa premissa inicial do pensamento do filósofo é importante para não reduzir sua filosofia apenas à questão do movimento ligada ao fluxo, como encontramos principalmente na pesquisa etimológica, distinguindo-nos, assim, do senso comum acerca da noção de fluxo. Quando ele diz sua frase mais célebre: "não é possível entrar duas vezes no mesmo rio", está, na verdade, provocando uma discussão ontológica sobre o próprio homem, sobre o ser e o não-ser. A metáfora do rio implica na percepção do fluxo, da flutuação e da fluidez da água que se move sem parar. Quando o homem, ao entrar no rio pela segunda vez já não é mais o mesmo, isso se dá não apenas pelo movimento das águas do rio, mas também pelo próprio homem, que se transforma constantemente. E, ao pensar essa transformação e o movimento que existe por trás dessa dinâmica, Heráclito acaba por contemplar as dimensões física e metafísica desse ser que é e não é ao mesmo tempo - convergência de contrários. No momento em que ele é, já está se transformando em algo que, até então, não era. Portanto, para o filósofo, o homem só existe na contradição, imerso num contínuo devir de um ser-emmovimento: apenas somos em fluxo. O fluxo é a força e a condição vital para a existência do ser.

Por meio da figura de Sócrates, Platão também nos diz que, de acordo com Heráclito, o movimento faz parte da própria essência de todas as coisas (PLATÃO; 2001:69), e que "o 'ser' significa 'o que se move' e o 'não ser', por sua vez, significa, como alguns lhe chamam, 'o que não se move'.” (PLATÃO; 2001:98). Para Heráclito, algo produzido pelo movimento só pode ser mantido por ele mesmo, daí a importância do fluxo na manutenção do estado das coisas, que só podem existir na transformação, ou seja, no próprio fluxo (COSTA; 2005:135).

Dessa maneira, o pensamento de Heráclito, hoje, acaba se tornando numa crítica ao que, séculos mais tarde, viria a se tornar o pensamento cartesiano que imprime um recorte não flexível sobre a realidade, muitas vezes separando um objeto de seu contexo para posterior 
observação. Se tudo está/é movimento, não há como desvincular essa dinâmica do fluxo de um objeto ou ser. Platão levanta a mesma questão em Crátilo (2001): “como pode ser alguma coisa aquilo que nunca é de certa maneira? Pois, se se suspende de certa maneira, é manifesto que, nesse momento, não está a alterar-se; por outro lado, se é sempre de certa maneira, e é o mesmo, como pode alterar-se ou mudar, não se afastando da sua própria forma?” (2001:124). Daí a concepção de que a harmonia vem da convergência dos contrários.

Esse pensamento, no entanto, abarca uma dimensão mais profunda, de caráter ontológico. Heidegger nos alerta para o perigo de abordarmos o pensamento de Heráclito deixando de investigar seus significados mais profundos, contentando-nos com uma sabedoria confortável pela saída da dialética: "Do ponto de vista de Heráclito, porém, não passa de saída por atalho, de fuga e covardia de pensamento" (1998:124), tendo em vista que a dialética, conforme a compreendemos hoje, se baseia no pensamento moderno, estranho ao pensamento originário grego.

Assim, comecemos a investigação acerca da profundidade do pensamento heraclitiano a partir do seguinte fragmento ${ }^{23}$ : “ouvindo não a mim, mas ao logos, é sábio concordar ser tudo-um.” (HERÁCLITO apud HIPÓLITO In:COSTA;2005:83). Em suas análises sobre os fragmentos de Heráclito, Heidegger nos esclarece que o 'logos' ( $\Lambda$ ó $\varsigma$ ) constitui a palavra

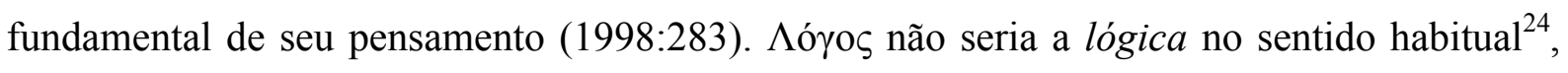
mas contemplaria, em sua essência, a questão do ser que, no caso do pensamento de Heráclito, não se desvincula da questão do não-ser.

Esse $\Lambda$ ó $\gamma$ os pertence ao ente que o homem é. Como colheita e reunião, como o um reunidor de tudo, o $\Lambda$ ó ${ }_{0} \varsigma_{\text {de }}$ que fala Heráclito não constitui uma propriedade dos entes. Esse $\Lambda$ ó ${ }_{0} \varsigma$ é a co-letividade originária que resguarda e preserva o ente como o ente que é. Esse $\Lambda$ ó em todo ente. (HEIDEGGER; 1998:288)

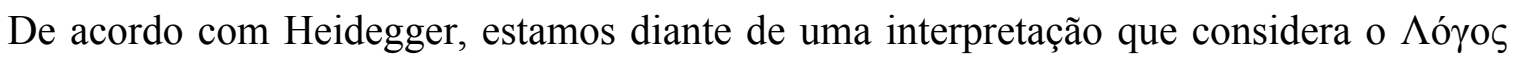
heraclitiano como uma esfera única que abrange tanto o ente quanto o ser do homem, ou seja, concebe uma visão de mundo pela mundividência; uma visão global, em que não há separação entre sujeito e objeto, em que posso tematizar o objeto da minha observação experimentando-o, sendo, mediante uma vivência dele. Ora, percebemos que o que Heidegger propõe como significado para o $\Lambda$ ó ${ }_{0} \varsigma$ realmente ecoa tanto a ideia de concepção dos

\footnotetext{
${ }^{23}$ Esse fragmento, a partir da obra 'Os fragmentos dos pré-socráticos' (Die Fragmente der Vorsokratiker) iniciada por Hermann Diels e continuada por Walther Kranz, é conhecido como o fragmento de número 50.

24 "Enquanto 'doutrina racional', a lógica é, portanto, o núcleo mais intrínseco do pensamento das ideias, ou seja, da metafísica” (HEIDEGGER; 1998: 282).
} 
contrários e do tudo-um de Heráclito, como também, a partir do momento que não desvincula o ser do ente, dá espaço a uma dinâmica que contém a noção de movimento e continuidade fluxo. Também vemos o quanto essa concepção de $\Lambda$ ó $o \varsigma_{\text {se }}$ aproxima do pensamento pela intuição (como propõe Bergson), ao abranger a importância da experiência estética subjetiva, conforme já expusemos aqui.

Antes de seguirmos, porém, vale destacar uma ressalva feita pelo próprio Heidegger. Segundo ele, estamos habituados, devido à tradição metafísica, a uma interpretação da relação do homem com o ente e o ser a partir da relação sujeito-objeto. No entanto, Heráclito é de uma época pré-metafísica e por isso às vezes nos custa compreender a total dimensão do significado de $\Lambda$ ó $о$ s. Portanto, devemos sempre ter em mente que "o $\Lambda$ ó $o \varsigma$ é a coletividade resguardadora que, como um, une o ente na sua totalidade e assim se apresenta como ser dos entes na totalidade." (HEIDEGGER; 1998:340).

Diante dessa interpretação, Heidegger reapresenta o fragmento de Heráclito, desdobrando aí alguns conceitos: "Se não auscultarem simplesmente a mim, mas atentarem articuladamente à coletividade originária, então (o) saber é o que consiste em recolher-se na coletividade e ficar recolhido no ‘tudo é um'.” (HEIDEGGER; 1998:317). Assim, enquanto o

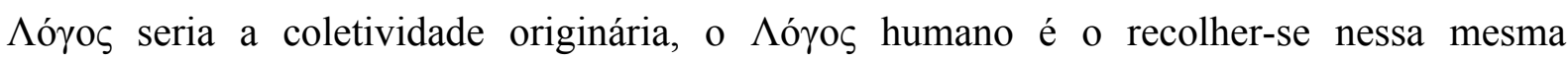
coletividade.

Desmembrando ainda mais os conceitos contidos nessa sentença, Heidegger recorre, segundo sua interpretação, a outro fragmento ${ }^{25}$ de Heráclito que diz: "O pensamento do sentido é (a) nobre coragem e isso porque é: recolher (do encobrimento para o desencobrimento) o desencoberto, no modo da pro-dução que pro-cede e con-cede, a partir da relação que toma e inspira a coletividade originária.” (HEIDEGGER; 1998:381). Após esse confronto, ele apresenta sua versão final da tradução do fragmento de Heráclito, da seguinte

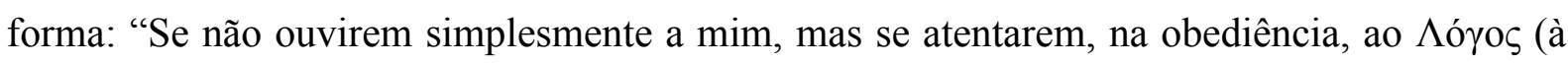
coletividade originária), então é (se dá) saber em sentido próprio, que consiste em recolher, com recolhimento, o uno único de tudo o que se une (ou seja, o presente da coletividade imaginária)”. (HEIDEGGER; 1998: 382).

Esse "uno único de tudo o que se une" (ou o tudo-um) se refere a mais que uma mera unificação do múltiplo, uma composição do muito, mas a uma reunião que contém em sua

\footnotetext{
${ }^{25} \mathrm{O}$ fragmento em questão, segundo 'Os fragmentos dos pré-socráticos' (Die Fragmente der Vorsokratiker) seria,

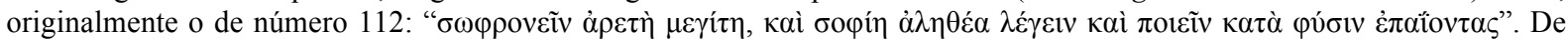
acordo com a tradução de Costa: "Bem-pensar é a maior virtude, e sabedoria dizer coisas verdadeiras e agir de acordo com a natureza, escutando-a" (2005:127).
} 
"unidade" o tudo originário (HEIDEGGER; 1998:274). O uno une tudo que é. E se apenas somos em movimento, podemos dizer que o uno representa o todo e que esse todo pode ser entendido também como fluxo e, assim, seria mediante o fluxo que teríamos a compreensão da unidade de tudo. Dessa forma, voltamos ao fragmento de Heráclito, reformulando-o da seguinte maneira: Se não ouvirem simplesmente a mim, mas se atentarem, na obediência ao

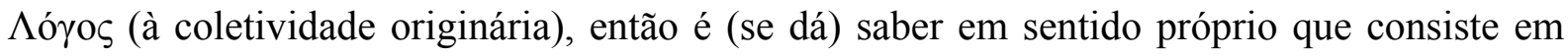
recolher, com recolhimento, o fluxo (ou seja, o presente da coletividade imaginária - ou o tudo-um).

Ao relacionar o fluxo à noção do tudo-um, nos chama atenção o fato de a tradução da obra do filósofo para o português recorrer a um constante uso dos hifens entre palavras que se relacionam, geralmente compostas de mais de um conceito, mas criando, naquela forma e momento, um conceito único. Segundo Costa (2005): “O uso do hífen traduz para português a unidade pretendida entre os elementos de cada um dos pares, visto que o original grego não apresenta entre eles qualquer conectivo.”(2005:83). Esse recurso se mostra uma boa alternativa para observação de um objeto dentro de seu contexto, tentando não isolá-lo de seu fluxo, tornando possível, assim, analisá-lo na relação com outros elementos e levando em conta a proposta de harmonia proveniente do encontro de contrários, defendida por Heráclito. Sobre essa relação, Costa faz um comentário pertinente, elucidando ainda mais o que quer dizer o filósofo grego:

O estabelecimento da relação que põe os polos em contato não implica a descaracterização dos polos enquanto polos nem reluta em subsunção. Há três momentos a destacar na esfera traçada pelo jogo de reunião e separação promovido pelo logos: A, B e A-B; multiplicidade, unidade e relação; tudo, um e tudo-um. A comunidade do logos consiste em abarcar e gerir os três momentos. Pois bem, o hífen do terceiro momento A-B, a tensão entre os polos opostos, este hífen recebe o nome de harmonia. (2005:165-166)

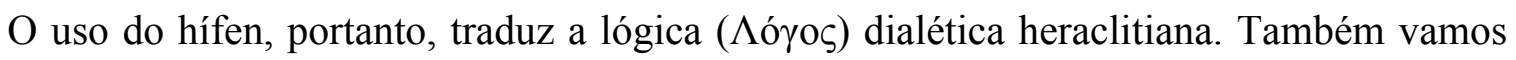
encontrar a presença desse recurso séculos mais tarde na tradução para o português da obra de Heidegger. Assim, esse sinal denota uma perspectiva de não separação; de um olhar mais abrangente que compreenda o ser como um todo, em fluxo, como também propõe Heráclito. No entanto, essa abordagem também deve levar em consideração a concepção heraclitiana da harmonia entre contrários, ou seja, a não separação que vislumbramos aí não implica uma continuidade ininterrupta do movimento, mas, sim, uma constante movimentação que carrega em si rupturas que, por sua vez, são o que garantem sua contiguidade. 
Assim, quando Heráclito diz 'tudo flui', está reafirmando a sua convicção no tudo-um e

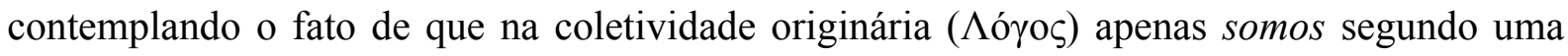
dinâmica de unidade que não cessa de se transformar: o homem como ser e ente ao mesmo tempo e em constante atualização de estados contrários ou opostos. E só mediante essa dinâmica é que chegamos à harmonia — quando tudo flui. Veremos nas manifestações de obras de artemídia apresentadas nos capítulos a seguir que sua própria concepção material reflete essa dinâmica ao se constituírem de imagens impalpáveis muitas vezes formadas por luzes intermitentes que chamam à participação do espectador e só se completam mediante essa interação, formando uma unidade momentânea, que dura segundo o tempo da experiência da obra num diálogo com estados de consciência diversos do ente que entra em contato com seu ser através dessa mesma obra.

\subsection{Crátilo: um diálogo entre Heráclito e Platão}

Em Crátilo Platão propõe um diálogo entre Sócrates, Hermógenes e o próprio Crátilo acerca de aspectos etimológicos da linguagem. Discute-se a origem dos nomes e a correção na sua aplicação e, a partir daí, são levantadas outras questões que acabam levando os interlocutores a abordar a teoria das formas e o fluxismo - é aí que encontramos alguns aspectos interessantes que retomam o pensamento de Heráclito e a partir dos quais procuraremos estabelecer um diálogo entre os dois filósofos, Heráclito e Platão.

Ao investigar a origem de alguns nomes, tais como o dos elementos básicos: água, fogo, terra e ar, Platão traz Sócrates ao debate, que por sua vez se refere ao aspecto móvel do $\operatorname{ar}^{26} \mathrm{e}$ segue seu diálogo com Hermógenes acerca da origem dos nomes das estações do ano e, em seguida, dos nomes que dizem respeito à virtude, como "razoabilidade", "compreensão" e “justiça”. Assim, Sócrates começa seu discurso referindo-se aos homens muito antigos, os que estabeleceram os nomes a priori:

Revolteando uma vez e outra, à procura daquilo que são os entes, ficam [os homens antigos] com vertigens, e depois parece-lhes que as próprias coisas revolteiam e que estão em constante movimento. E não atribuem a causa desta opinião à sua afecção interior, mas à natureza das próprias coisas, nas quais nada há de estável e seguro, já que todas elas fluem constantemente e estão em movimento e estão todas cheias de mobilidade e de gerações (PLATÃO; 2001: 83)

\footnotetext{
${ }^{26}$ Em nota de rodapé, o tradutor do livro nos mostra que aêr quer dizer ar em grego. E aei rhei é a palavra grega para designar movimento. (FIGUEIREDO In: PLATÃO; 2001:81)
} 
Percebemos, no discurso de Sócrates, ecos da filosofia heraclitiana quando se refere à natureza móvel e fluida das coisas. Sócrates ainda complementa seu pensamento ao dizer que “os nomes foram atribuídos às coisas precisamente por estarem em movimento e fluírem e se gerarem.” (PLATÃO; 2001:83).

Daí podemos inferir que, se a própria natureza das coisas é o fluxo, nós também somos seres em fluxo, ou seres-em-movimento, como afirmamos anteriormente. E que o conhecimento da realidade que se apresenta a nós só pode se dar se nos mantivermos nesse fluxo, ao mesmo tempo em que a realidade também aí está; em constante mudança. Sócrates, ao perceber tal dinâmica, reconhece a dificuldade em persistir nesse caminho e de examiná-lo, mas encoraja Crátilo a perseguir essa investigação.

O filósofo continua seu pensamento ao relacionar a noção de "bom" ao movimento. Ele diz que o nome "bom" significa aquilo que é admirável e que, estando os entes em movimento, esse contém as dimensões da velocidade e da lentidão, sendo a velocidade considerada admirável. Assim, a essa parte admirável do movimento - a velocidade ou a rapidez - é dada a designação de "boa". Era muito comum, na antiguidade grega, atribuir à noção de bom a de belo e verdadeiro. Daí compreendermos porque Sócrates afirma que a mobilidade divina do ser parece ser designada pela palavra "verdade" (alêtheia), assim como a "falsidade" estaria ligada ao que é retido ou forçado a permanecer em repouso (PLATÃO; 2001:98).

Da mesma forma, para ele, o que se move mal constituiria, então, um vício e não uma virtude, por sua vez significada como " [...] o fluir sempre desimpedido da alma boa; fluindo sempre irresistível e livremente." (PLATÃO; 2001:89). E, ainda, o "prejudicial” seria aquilo que quer prender o fluir (Ibidem:92) — assim como a "aflição" é aquilo que entrava o moverse. Já a "alegria" parece receber o nome "[...] da difusão e da boa marcha do fluir da alma" (Ibidem:95) - encontramos aqui também a possibilidade de manifestação da ideia de "regozijo" que levantamos anteriormente.

Sempre nos pareceu um pouco ingênua essa divisão quase maniqueísta que os antigos filósofos gregos fazem entre o bem, associado ao belo e à verdade, e o mal, associado ao feio e ao falso. Não queremos aqui impor um juízo de valor ou afirmar que esta seja uma interpretação certa ou errada, para também não cairmos na mesma armadilha, até porque são diferentes os contextos das épocas antiga e contemporânea. No entanto, não acreditamos que tal polarização, tão dicotômica, seja adequada ao fluxo, por sua natureza em constante mudança (devido às interrupções advindas da tensão entre os contrários) e, justamente devido a isso, de difícil apreensão. 
Apesar das relações feitas por Sócrates acerca da origem dos nomes, suas investigações dão evidências de situações tanto do movimento quanto do repouso nessa tarefa. Dessa forma ele não deixa completamente de lado a dinâmica de que os próprios nomes são fruto do embate de ideias contrárias, permeando tanto a situação de mobilidade quanto a de imobilidade: "aqueles nomes que consideramos serem das piores coisas parecer-nos-ão semelhantes aos nomes das melhores coisas. E penso que, se alguém se empenhasse nisso, descobriria muitos outros nomes a partir dos quais chegaria à ideia contrária."(PLATÃO; 2001:121).

Em relação à harmonia, Sócrates afirma que o movimento harmonioso seria o que se chama de "boa disposição" (PLATÃO; 2001:95). Notemos que o critério em questão é muito aplicado ao mundo da arte, por exemplo, quando falamos da composição de um quadro, de um enquadramento de cinema ou fotografia ou ainda da distribuição dos elementos na página, no caso de uma peça de design. Podemos inferir, então, que uma boa disposição está ligada à ideia de harmonia (entre contrários) e também à ideia de fluxo. Sócrates faz ainda uma relação da noção de movimento e fluxo com outra palavra (ou nome): o "desejo": "esse nome foi dado ao fluxo que mais arrasta a alma; porque se lança a fluir ${ }^{27}$, deixando-se levar contra as coisas, atraindo assim fortemente a alma por meio da força deste fluxo, e é por todo esse poder que foi chamado 'desejo'.” (PLATÃO; 2001:96).

Ao partir para uma análise das próprias palavras "fluxo", "mover-se" e "suspensão", Sócrates nos informa que elas são consideradas palavras ou nomes primitivos. Essa noção de movimento está relacionada à essência das coisas (ôsia), tanto para Sócrates quanto para Heráclito: "todas as coisas se movem e nada permanece” (PLATÃO; 2001:69), e justamente por isso é que Sócrates acredita não ser coincidência a escolha dos nomes "Reia" e "Cronos" para os pais dos deuses, pois ambos significam nomes de fluxos. Em grego, Reia é Peı ou Pعa. Em latim: rheia ou rhea, que significa fluxo e facilidade. Ela representa o eterno fluxo de tempo e gerações; a grande mãe dos deuses do olimpo. Também era relacionada à fertilidade. Cronos, em grego Xpovos e em latim chronus significa 'tempo', noção que, desde sempre, está associada à ideia de fluxo.

Assim, tanto em Heráclito quanto em Platão nos parece clara a noção de que a natureza das coisas e do próprio homem está ligada ao fluxo. No entanto, o fluxo se constitui a partir de noções contrárias e, daí, a dificuldade em analisar as coisas (ou os nomes ou ainda a própria realidade) a partir de uma metodologia que as considere como parte desse fluxo.

\footnotetext{
27 “Desejo" em grego é himeros. "Lança-se a fluir" em grego é hiemenos rhei
} 
Sócrates, ao final do diálogo, confessa a Crátilo não poder afirmar qual é realmente a natureza dessas coisas, ao mesmo tempo em que o incentiva e continuar suas reflexões nesse sentido. Não encontramos, porém, a noção de unidade, de logos (como coletividade) ou de tudo-um, como afirma Heráclito em relação ao fluxo, no pensamento de Platão. De forma que partimos para uma investigação do pensamento de Giordano Bruno nesse sentido, para também poder relacioná-lo ao de Heráclito.

\subsection{O uno em Giordano Bruno e a relação com a dialética heraclitiana}

Giordano Bruno, teólogo e filósofo nascido na Itália em 1548, chegou a ser frade, no entanto, foi perseguido pela Inquisição da Igreja Católica por suas ideias acerca do homem, do universo e do infinito - sendo condenado a morrer queimado em 1600 no Campo dei Fiori, em Roma. Dentre seus pensamentos, nos voltaremos à questão do uno e de como suas ideias se relacionam ao tudo-um heraclitiano. Bruno teve uma formação calcada no aprendizado da filosofia grega antiga, principalmente de Aristóteles, a quem faz tantas críticas. Seu pensamento, de forma geral, acabou seguindo um caminho mais próximo às ideias de Platão. No entanto, percebemos, em alguns pontos de seu discurso, ainda um eco das ideias aristotélicas - como no caso em que Bruno fala da matéria e de sua transformação em forma, numa dinâmica que passa da potência ao ato.

A potência não é igual ao ato, porque este ato não é absoluto, porém
limitado; além do que a potência é sempre limitada a um único ato, porque
ela jamais possui mais do que um ser específico e particular; e, mesmo que
aspire a toda forma e a todo ato, isto se dá mediante certas disposições e com
certa sucessão de seres. Por conseguinte, toda potência e todo ato que, no
princípio, acham-se como que complicados, unidos e unos, nos seres
particulares, porém, são desenvolvidos (explicados, dispersos e
multiplicados) (1998:85)

Giordano Bruno afirma que, diante do infinito (ou do universo) e das possibilidades aí existentes, o homem e suas ações encontram-se limitados, ligados a uma atualização que se dá da potência ao ato (ou da matéria à forma): “O homem é o que pode ser, mas não é tudo o que pode ser." (1998:85). Para o filósofo, aquilo que é tudo o que pode ser é uno, "o qual, no seu ser, abrange todo ser. Ele é tudo o que é e pode ser um objeto qualquer que é ou pode ser" (Ibidem:85). A semelhança que aí encontramos com o pensamento de Heráclito nos remete ao uno ou ao tudo-um, que constitui mais que uma unificação do múltiplo, mas, sim, uma unidade que contém o tudo originário - o uno une tudo o que é. 
O filósofo italiano, devido a sua formação teológica e ligação com a Igreja Católica, acaba relacionando a ideia de uno também a Deus. Segundo ele, Deus também é tudo o que pode ser e "Ele será todo junto e inteiro por toda parte e em tudo; Ele é tão absolutamente móvel e rápido que, por isso mesmo, é absolutamente estável e imóvel” (BRUNO; 1998:87). Tal qual Heráclito, Bruno concebe o uno como inteiro e indivisível e recorre à associação com o movimento para abordar a unidade dos contrários que o compõem (noção cara também a Heráclito). Bruno também reconhece que existe uma harmonia que surge do confronto entre contrários, sendo um contrário o princípio do outro, gerando um ciclo. Segundo ele, isso acontece pois "nos contrários existem um [mesmo] sujeito, um princípio, um termo, uma continuidade e uma fusão.” (BRUNO; 1998:131). Bruno acredita que o princípio do ser é uno, assim como uno é o princípio da concepção dos objetos.

Ele dá continuidade ao seu raciocínio acerca do uno ao especificar o caráter da inteireza de Deus (ou do próprio uno), afirmando que um ser indiviso acaba contendo o divisível e, assim, se constitui na "potência de todas as potências; ato de todos os atos; vida de todas as vidas; alma de todas as almas; ser de todo ser.” (BRUNO; 1998:88). Ora, podemos fazer aí também uma relação com a coletividade originária, ou o logos heraclitiano ( $\Lambda$ ó $о$ ) $)$.

Bruno também acredita que o uno pertence à esfera das formas transcendentes e, por isso, não distingue a matéria, como também não faz dela duas potências diferentes. $\mathrm{O}$ uno ainda abrangeria "tanto as substâncias corpóreas quanto as incorpóreas e designa a substância universalíssima, comuníssima e mutuamente idêntica.” (BRUNO; 1998:99-100). E por seu caráter indiviso, que contém também os contrários, Bruno ainda acredita que, no uno, a matéria também é forma, assim como a potência é ato ou o ser coincide com a possibilidade de ser. Antes de assumir alguma forma, a matéria tem a possibilidade de se transformar em toda e qualquer forma; a forma, portanto, estaria no seio da matéria (BRUNO; 1998:110).

Além da questão indivisa e global do uno, Bruno também faz uma abordagem que relaciona o movimento à potência e à matéria:

A noção de potência se coaduna com o que está em contínuo movimento com relação à matéria; e não com aquela que se acha no eterno estado de repouso e que é, inclusive, causa do repouso; porque se a forma, segundo seu ser fundamental e específico, é de essência simples e invariável - não só quanto à lógica, no conceito e na razão, mas também fisicamente na natureza - é preciso que ela se ache confundida na perpétua faculdade da matéria, que é uma potência indistinta do ato, conforme tenho explicado de diversas maneiras, quando tantas vezes tenho discorrido sobre a potência (BRUNO;1998:110-111). 
$\mathrm{O}$ ato atualiza a matéria em forma, numa dinâmica constante de mudança que se dá não pela simples vontade de mudar, mas por buscar outra maneira de ser latente na potência dessa mesma matéria (que, por ser una, contém todas os modos de ser). Consequentemente, toda coisa, em sua forma, também é una, mas sob modos diferentes (BRUNO; 1998:120). É o conjunto dessas possibilidades e a constante transformação de matéria à forma por meio da passagem da potência ao ato que abraça a noção de movimento, ou fluxo, na filosofia de Giordano Bruno, pois o uno - ou o infinito, ou o universo - em si, por conter tudo o que existe, seria imóvel, na concepção do filósofo. Essa seria a grande diferença entre o seu pensamento e o de Heráclito, para quem o tudo-um está em constante movimento.

Podemos apontar, então, que existe uma divergência entre o pensamento dos dois filósofos em relação à questão do movimento. Apesar de não descartar a importância e a dimensão do movimento no universo, Giordano Bruno acredita que essa dinâmica faz parte das transformações que aí ocorrem mas não consituiriam a natureza do universo propriamente dita. O fluxo, no entanto, não perde sua importância, pois, para o filósofo, o uno se estrutura justamente sobre uma ação constante de mudança que se dá na atualização de situações, valores e princípios contrários. Somente então mediante esse movimento é que a harmonia do universo se torna alcançável e constitui o uno. É aí onde reside a maior coincidência entre as ideias de Heráclito e de Giordano Bruno: na concepção do uno pela harmonia entre os contrários, mediante uma dinâmica fluida e dialética.

Dessa forma, podemos dizer que a importância dada ao equilíbrio entre os opostos é o que chama maior atenção no pensamento de Bruno, mas sem esquecer o também importante papel do fluxo como pano de fundo para esse cenário: "Em conclusão, quem quer conhecer os maiores segredos da natureza que olhe e contemple os mínimos e os máximos dos contrários e opostos. Profunda magia é saber discernir o contrário depois de ter encontrado o ponto de união" (BRUNO; 1998:112).

\subsection{Heidegger retoma Heráclito}

Em um seminário sobre Heráclito realizado na Universidade de Friburgo no inverno de 1966-1967, Martin Heidegger e Eugen Fink analisam alguns fragmentos do filósofo grego, dentre os quais nos chama atenção a relação com o movimento e a questão do $\lambda$ ó em sua ligação com a $\dot{\alpha} \lambda \hat{\eta} \theta \varepsilon ı$ (alétheia) — presente na filosofia de Heidegger mediante a noção de clareira e a dinâmica do desvelamento. Heidegger ainda escreveu, em 1970, um livro onde analisa os fragmentos de Heráclito, o qual também consultamos. 
Heidegger e Fink começam suas análises de Heráclito pelo fragmento $64^{28}$ : "O relâmpago governa a totalidade do mundo."29 (FINK, HEIDEGGER; 1986:8). Segundo Eugen Fink, esse fragmento não faz referência a uma multiplicidade de entes em repouso estático, mas, sim, a um movimento, principalmente no que se refere à figura do relâmpago ${ }^{30}$ pois, na claridade provocada por esse fenômeno, vislumbramos a mobilidade da totalidade do mundo ou de todas as coisas do mundo (ambas as ideias são expressas em grego pela expressão $\tau \grave{\alpha} \pi \hat{\alpha} v \tau \alpha$, presente no fragmento 64). Fink ressalta que, apesar da relação existente entre os dois movimentos, há uma diferença entre o movimento físico do relampejar no irromper da claridade e o movimento de $\tau \grave{\alpha} \pi \alpha ́ v \tau \alpha$ (todas as coisas).

Heidegger afirma que o movimento do qual trata Heráclito não seria de natureza

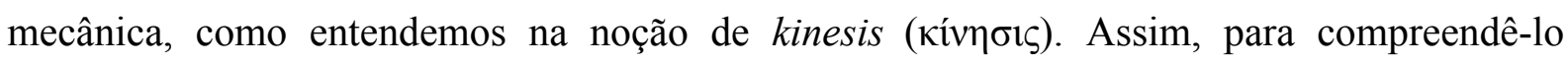
melhor, Heidegger recorre ao fragmento 41 e posteriormente ao fragmento 1 . No primeiro deles temos: "Uma só é a sabedoria: o pensamento que sabe governar tudo através de tudo." 31 (FINK, HEIDEGGER; 1986:11). Aqui, ambos chamam atenção para a noção de movimento contida na expressão 'através de' ( $\delta$ ì̀), que aponta para o movimento que governa tudo

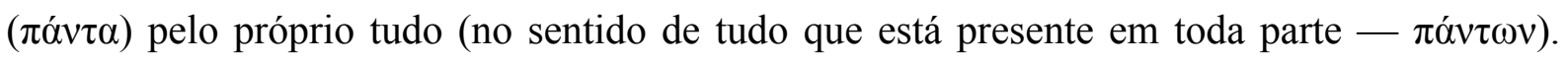
Voltando ao fragmento 64, se o relâmpago governa a totalidade do mundo ( $\tau$ à $\pi \alpha ́ v \tau \alpha$ ) então, aí também, se encontra a noção de movimento - tanto pela luz que resgata visivelmente o contorno das coisas da escuridão em que se encontravam, quanto pela relação (através de) do tudo em tudo. Para complementar esse pensamento, Heidegger volta-se ao fragmento $1^{32}$ :

Desse lógos, sendo sempre, são os homens ignorantes tanto antes de ouvir como depois de o ouvirem; todas as coisas vêm a ser segundo esse lógos, e ainda assim parecem inexperientes, embora se experimentem nestas palavras e ações, tal como eu as exponho, distinguindo cada coisa segundo a natureza e enunciando como se comporta. Aos outros homens, encontre-se tanto o que fazem acordados, como esquecem o que fazem dormindo. ${ }^{33}$ (In: COSTA; 2005: 41)

\footnotetext{
${ }^{28}$ Quando abordam os fragmentos de Heráclito, Fink e Heidegger se referem à obra 'Os fragmentos dos pré-socráticos' de Hermann Diels e Walther Kranz

${ }^{29} \tau \grave{\alpha} \delta \dot{\varepsilon} \pi \alpha ́ v \tau \alpha$ oi $\alpha \kappa i ́ \zeta \varepsilon \iota ~ \kappa \varepsilon \rho \alpha v v o ́ \varsigma$

${ }^{30}$ Em Heráclito, o relâmpago está em conexão com a ideia de fogo $(\pi \bar{v} \varrho)$

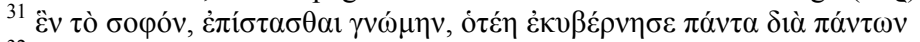

${ }^{32}$ Para melhor compreensão da tradução deste fragmento para o português, recorremos à tradução em espanhol encontrada no livro de Heidegger e Fink (1986), bem como ao livro de Alexandre Costa (2005).

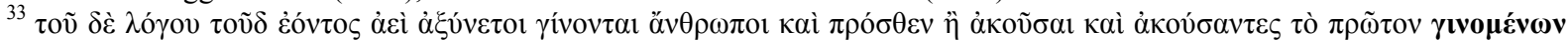

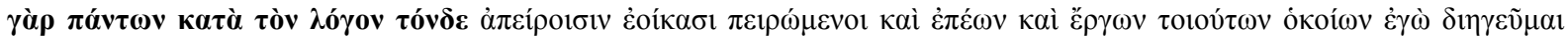

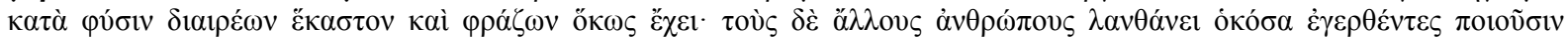

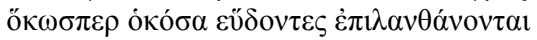


Desse trecho Heidegger recorta a seguinte frase: “[...] todas as coisas vêm a ser segundo

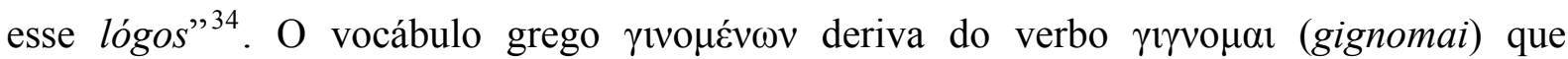
significa, segundo o Dicionário Grego-Português | Português-Grego: 'fazer-se, ser, chegar a ser, nascer, ter, lugar, produzir, suceder, sair, falando do tempo, passar, chegar, vir, subir, pertentcer a, ser de, tornar-se" (BRAGA, PEREIRA; 1990). Alexandre Costa (2005:40) também faz um comentário acerca dessa passagem, dando destaque para a expressão "vêm a

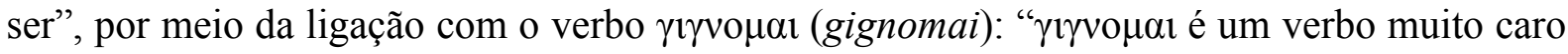
a Heráclito, presente, portanto, em muitos fragmentos. A sua tradução, porém, alternará conforme o contexto que se emprega, sendo possível encontrá-lo como 'vir a ser', 'devir', 'tornar-se', 'ser', 'acontecer' e outras formas similares".

Retomando o raciocínio de Heidegger ao propor uma ligação entre os fragmentos 64, 41 e 1, podemos inferir que, o movimento do qual Heráclito fala se refere à mobilidade que governa tudo através de tudo que existe, de tal forma que tudo vem a ser tudo o que existe tal qual se dá com o relâmpago que, através da luz e da claridade, faz as coisas se tornarem no que elas realmente são (ou serem vistas e percebidas como realmente são), ao resgatar suas formas das sombras. Esse pensamento ecoa na filosofia heideggeriana por meio da ideia de clareira e desvelamento.

Para Heidegger o dasein ${ }^{35}$ (ser-aí) se revela na clareira. Esse movimento (vir-a-ser) de desencobrir (desvelar) o que está encoberto (nas sombras) para chegar à essência das coisas acaba nos levando de volta à relação do homem com o lógos, conforme encontramos no fragmento 1: quando estamos nas sombras ignoramos o lógos; estamos encobertos e não enxergamos as coisas (o todo, ou tudo) como realmente são. Neste ponto podemos também retomar o fragmento 50, do qual falamos anteriormente: “ouvindo não a mim, mas ao logos, é sábio concordar ser tudo-um". Ou seja, quando experimentamos o movimento de passar do enconbrimento ao desencobrimento; estando na clareira, podemos ouvir ao lógos e, nessa situação, percebemos a unidade de todas as coisas - o uno.

A noção de clareira é central em Heidegger. Para o filósofo, a própria essência da

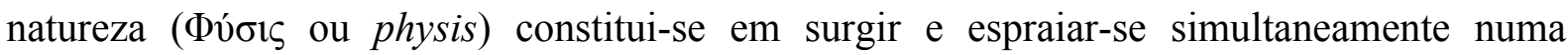
abertura e clareira. Ele recorre ao exemplo da deusa Artémis, que é caracterizada por uma figura que possui tochas em ambas as mãos. Ela é a portadora da luz e carrega a claridade sem a qual nada aparece, sem a qual nada pode sair do encobrimento para o desencobrimento

\footnotetext{
34 vide negrito do trecho em grego na nota anterior

${ }^{35}$ Conceito importante e recorrente na filosofia de Heidegger e que é amplamente discutido principalmente em sua obra Ser e Tempo, de 1927
} 
(HEIDEGGER; 1998:31). A clareira abriga abrindo e clareando; ela é a essência originária que se vela na $\dot{\alpha} \lambda \eta \dot{\theta} \theta \varepsilon 1 \alpha$ (verdade) - quando as coisas são vistas como o que realmente são. No entanto, Artémis também significa o aparecimento do contrário, de modo a nunca favorecer um dos lados a fim de superar o outro. Podemos inferir que, na clareira, ou na $\dot{\alpha} \lambda \eta \dot{\theta \varepsilon \imath \alpha}$, também estamos diante de uma harmonia que se constrói sobre o divergente. $\mathrm{O}$ movimento se dá, aí, de um contrário a outro, na alternância do escuro ao claro - ou do encobrimento ao desencobrimento - assim como nos percursos das obras-instalações da artemídia.

Esse movimento carrega em si a noção de devir, não de um devir moderno, como alerta Heidegger, mas, conforme o pensamento grego, um "chegar a ser, mostrar-se em presença" (FINK, HEIDEGGER; 1986:13). Fink complementa esse pensamento ao dizer que se trata, neste caso, de um movimento do trazer-à-luz, que também é o movimento do relâmpago, que tudo governa (referência ao fragmento 41) e, por isso, é o movente (através do que se dá o movimento - $\delta i \grave{\alpha}$ ). Assim como o relâmpago, continua Fink, também é o lógos em relação a todas as coisas: tudo dirige, governa e determina.

O movimento do qual falamos aqui se trata de um devir que ocorre através de um processo de desvelamento de tudo o que existe, mostrando as coisas como elas realmente são.

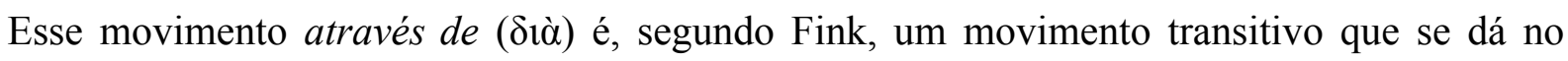
encontro entre os contrários. A partir dessa dinâmica Heidegger afirma que o todo não pode ser homogêneo (assim como Heráclito também fala sobre o uno). E, justamente por ser diverso, constituído de contrários, é que existe sentido em pensar o movimento do através de, que promove a relação entre os divergentes em busca da harmonia.

Percebemos, então, como as ideias de Heráclito acerca do fluxo repercutem em Heidegger principalmente no que diz respeito ao movimento através do qual as coisas são levadas à clareira, ao encontro de seu verdadeiro ser. Ainda não devemos esquecer que esse movimento contempla a divergência e a complementariedade de contrários que aí existe, formando um todo (uno) que serve de cenário para essa relação entre luz e sombra. Tal movimento engloba uma noção que muito influenciou outros filósofos da era moderna e contemporânea, como Hegel, Nietzsche, Bergson e Deleuze: a noção de devir — a qual investigaremos adiante. 


\subsection{O devir heraclitiano repercute em Hegel, Nietzsche, Bergson e Deleuze}

Seguimos buscando as repercussões do pensamento heraclitiano que nos sirvam de guia para compreender as abordagens e refinamentos do entendimento da noção de fluxo. Obviamente que uma sistematização do pensamento heraclitiano no ocidente não é possível no limite dessas páginas, nosso esforço volta-se ao vislumbre de um panorama dessas repercussões ao longo dos séculos no pensamento de vários filósofos. Para Hegel, Heráclito é o filósofo do fluido, e o elemento fluido teria um caráter de modelo para dissolução dos opostos. Já discorremos sobre a importância que Heráclito dá aos contrários, de cuja relação se extrai a harmonia do uno. Hegel se apoiará nesse pensamento para realizar seus estudos sobre a Lógica. Em seu livro, publicado em 1816, Ciência da Lógica, o filósofo aborda essas questões, que o levam a discorrer também sobre o ser e o devir.

Em Hegel a Lógica é a ciência pura, ou o saber puro (2011:51). Tal qual o ser puro, o saber puro é inteiramente abstrato e não mediado, ou seja, constitui o início ${ }^{36}$. Apesar de seu caráter imediato, o início não deve ser tomado pelo nada puro, mas por um nada do qual algo deve partir, ou seja, o início deve ser entendido como uma unidade de ser e nada, em que esses opostos estão em unificação imediata, constituindo um devir: "eles (ser e nada) não são o mesmo, são absolutamente distintos, mas igualmente inseparados e inseparáveis e imediatamente cada um desaparece em seu contrário. Sua verdade é, portanto, esse movimento do desaperecer imediato de um no outro: o seu devir." (HEGEL; 2011:72).

Hegel retoma a máxima heraclitiana — tudo flui — a partir da frase: tudo é devir. Podemos entender que quando o filósofo alemão diz que o fluido serve de modelo para dissolução dos opostos acredita que o fluido é devir. Dessa maneira, estaríamos imersos em uma realidade formada por uma unidade constituída de contrários - a saber, o ser e o nada —, em constante movimento. Cada elemento dessa unidade contém um pouco de seu contrário: "O devir é o subsistir do ser bem como do não ser; ou seu subsistir é apenas seu ser em um, justamente esse seu subsistir é o que igualmente supera sua diferença." (HEGEL;

\footnotetext{
36 “O principio de uma filosofia certamente expressa também um início, mas menos um início subjetivo do que um início objetivo, o início de todas as coisas. O princípio é um conteúdo de algum modo determinado: a água, o um, o nous, a ideia a substância, a mônada, etc.; ou quando se relaciona à natureza do conhecimento e assim deve ser antes um critério do que uma determinação objetiva - o pensar, o intuir, o sentir, o eu, a subjetividade mesma -, então aqui o interesse igualmente se dirige para a determinação do conteúdo. [...] Se o pensamento anteriormente abstrato de início apenas se interessa pelo princípio como conteúdo, mas na progressão da formação é impulsionado a atentar para o outro lado, para o comportamento do conhecimento, então o atuar subjetivo também é apreendido como momento essencial da verdade objetiva e surge a carência de que o método seja unido ao conteúdo, a forma ao princípio. [...] Lógico é o início se ele deve ser feito no elemento do pensamento existente livre por si mesmo, no saber puro." (HEGEL; 2011:49-51)
} 
2011:82). Portanto, aquilo que é uma unidade junto ao seu contrário, o é em movimento (em devir) e não nas partes isoladas do todo.

A realidade deveria ser percebida e compreendida apenas pelo devir. Nem o ser nem o nada são verdadeiros, mas somente o devir, em sua unidade dialética: "É da natureza dialética do ser e do nada que eles mesmos mostrem sua unidade, o devir, como a sua verdade." (HEGEL;2011:96). Por conseguinte, ambos movimentos contrários, tanto do desaparecimento — do ser ao nada - bem como do nascimento — do nada ao ser —, constituem um mesmo devir, chegando a um equilíbrio. O devir se contradiz em si mesmo porque une em si aquilo que é oposto para si. É justamente devido a essa dinâmica que seu equilíbrio atinge a harmonia no uno (ou na unidade), como já destacava Heráclito na antiguidade grega.

Dessa forma, o devir, segundo Hegel, constitui a própria existência (dasein) e assegura a continuidade dessa mesma existência - e também do próprio devir — em seu movimento, pois "algo é apenas superado ao entrar em unidade com o seu oposto." (HEGEL; 2011:98). Forma-se um ciclo de difícil apreensão, e ao tentar fazê-lo devemos observar alguns obstáculos metodológicos que se interpõem em nosso caminho, como aponta Hegel - e também Bergson. O filósofo alemão nos indica que, ao nos propormos a tal tarefa, deveríamos, inicialmente, esquecer todo o movimento, deixando conservada apenas a intuição - aí já teríamos o primeiro desafio. Também Bergson acredita que uma apreensão da realidade que se pretenda mais próxima da realidade seria guiada pela intuição.

Outra indicação proposta por Hegel se constitui no fato de não pensarmos em nós mesmos como distintos do próprio devir, e, nesse ponto, ele retoma a importância do uno também presente em Heráclito. A relação de apreensão do devir deve ser de tal forma que não sejamos envolvidos por ele, mas devemos "passar inteiramente por ele, ser uno com ele, transformar-me nele; não devo conservar em mim mais nada senão essa minha intuição mesma, a fim de considerá-la como uma representação verdadeiramente autônoma, independente, única e sozinha." (HEGEL; 2011:87).

O pensamento pela intuição já se mostrava presente na filosofia de Heráclito. Segundo Nietzsche é o pensamento estético e intuitivo que constitui o trágico - adjetivo que atribuía como alcunha ao filósofo grego. Nietzsche considera a visão de mundo trágica superior à visão moderna, ligada à moral e ao reino da lógica. Somente uma intuição estética permitiria aos filósofos pré-socráticos libertarem-se do previamente pensado para inventarem a filosofia, dinâmica que, segundo Nietzsche, estreita as relações entre a filosofia e a arte.

Em seu livro A filosofia na época trágica dos gregos (2012), Nietzsche se volta várias vezes a Heráclito. Ele nos conta como o filósofo grego olhou para a mesma questão do vir-a- 
ser - ou devir — sem encontrar ali injustiça ou encará-la como uma situação tormentadora, como tanto alardeava outro filósofo conterrâneo e anterior a Heráclito, Anaximandro (610 a.C. - 547 a.C.) - segundo quem tudo o que alguma vez veio a ser logo volta a perecer. Nietzsche atribuia essa "visão maravilhosa" de Heráclito à sua capacidade intuitiva, pois somente dessa forma acreditava ser possível exercer um desapego em relação às convenções e opiniões gerais, guiando-se por uma noção própria extraída da experiência individual.

Para Nietzsche, a intuição é estética por natureza, pois ela não julga ou condena, mas contempla e admira. Ao contrário da razão, que age por meio de conceitos fixos, a intuição se desenrola no âmbito do devir. Nietzsche admira a forma como Heráclito encarava esse estado de eterna mudança de maneira diferente em relação a Anaximandro, por exemplo — para quem o devir implicava também decadência.

Um vir a ser e perecer, um construir e destruir, sem qualquer acréscimo moral, numa inocência eternamente idêntica, neste mundo existe apenas no jogo do artista e da criança. E do mesmo modo que a criança ou o artista brincam, brinca também o fogo eternamente vivo, construindo e destruindo sem culpa. (NIETZSCHE; 2012:68)

Segundo Nietzsche, apenas o homem estético poderia ver o mundo a partir de uma postura contemplativa (2012:69). A importância da dimensão do jogo na filosofia do efésio pode ser percebida em uma história que encontramos em Heráclito (1998), de Heidegger, em que o filósofo aparece jogando dados com crianças, no santuário de Artémis. Ele se dirige aos seus conterrâneos, que o observam, e diz: "Seus infames, o que estão olhando aqui tão

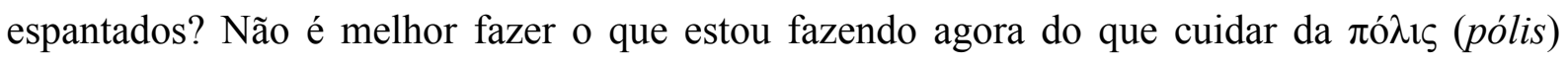
junto com vocês?" (In: HEIDEGGER; 1998:37).

Assim como Heráclito, Nietzsche também voltou seu olhar à unidade dos opostos, constituinte do próprio devir. Em sua visão, essa unidade se constituiria por um embate, ou uma guerra que, segundo ele, em Heráclito representava 'travar uma guerra' contra si mesmo - processo necessário no vir-a-ser (ou tornar-se) de cada indivíduo. A instabilidade contida na noção de guerra representa, em Nietzsche e em Heráclito, a conjuntura de estados provisórios de cada homem, bem como de todas as outras coisas do mundo, o que leva o eu a estar submetido a um contínuo devir.

Segundo Heráclito, apenas o ser humano limitado vê separadamente e não junto, não para o deus omni-intuitivo; para ele, toda contrariedade conflui para uma harmonia, a qual, embora invisível para o olho humano comum, é compreensível para quem, como Heráclito, se assemelha ao deus contemplativo. (NIETZSCHE; 2012:68) 
Há, em ambos filósofos, uma interconexão entre homem e mundo, pois a multiplicidade humana se constitui a partir da multiplicidade do próprio mundo. O devir sobre si é derivado do devir do mundo. Nietzsche concordava com Heráclito em relação à não diferenciação entre um mundo físico e um mundo metafísico, ambos viam apenas o vir a ser (e não o ser), numa dimensão cosmológica e não metafísica - o que também vai repercutir na sua filosofia do eterno retorno. Diferentemente da filosofia platônica, por exemplo, Nietzsche retomava Heráclito ao perceber que um mundo fluido, em constante devir, só pode ser apreendido a partir de diferentes aspectos, num embate entre os contrários - que em sua filosofia foi abordada segundo o ímpeto fervoroso de união entre o apolíneo e o dionisíaco, principalmente no livro $O$ nascimento da tragédia (2007), escrito em 1876.

Apolo é o deus da beleza, representa o equilíbrio harmônico em que todas as coisas ganham forma na multiplicidade da aparência. Já Dionísio simboliza o uno-primordial, o caos que reúne todas as coisas sobre si e contém a unidade dos contrários, que por sua vez também resulta em harmonia, mas sob a tensão do embate. Dionísio é o deus da música, do delírio e da embriaguez: construção e destruição. Ele rege o fluir e o perecer de todas as coisas, "é o nome para o eterno fluxo do vir-a-ser." (LUCCHESI: 1996). É com a filosofia dionisíaca, portanto, que Nietzsche supera o dualismo metafísico ao adentrar o universo do trágico.

O dizer-sim à vida, até mesmo em seus problemas mais estranhos e mais duros, a vontade de vida, alegrando-se no sacrifício de seus tipos mais superiores à sua própria inexauribilidade - foi isso que denominei dionisíaco, foi isso que entendi como ponte para a psicologia do poeta trágico. Não para desvencilhar-se do pavor e da compaixão, não para purificar-se de uma afecção perigosa por uma descarga veemente — assim o mal-entendeu Aristóteles - mas para, além do pavor e da compaixão, ser ele mesmo o eterno prazer do vir-a-ser - esse prazer que encerra em si até mesmo o prazer pelo aniquilamento. Nesse sentido, tenho o direito de entender-me como o primeiro filósofo trágico [...]. Restou-me uma dúvida quanto a Heráclito, em cuja proximidade me sinto mais aquecido, sinto mais bem-estar do que em qualquer outra parte. A afirmação do preenchimento e do aniquilamento, o que é decisivo em uma filosofia dionisíaca, o dizer-sim à contradição e à guerra, o vir-a-ser, com radical recusa até mesmo do conceito de 'ser' - nisso tenho de reconhecer, sob todas as circustâncias, o mais aparentado a mim que até agora foi pensado (Trecho do texto "Sobre 'O Nascimento da Tragédia'”' — 1888 — In: NIETZSCHE;1999:47)

Tanto em Heráclito quanto em Nietzsche, a discórdia é motivo de harmonia. Aqueles que vêm Heráclito como taciturno ou obscuro, segundo o filósofo alemão, é porque não estão satisfeitos com a descrição da natureza do homem dada pelo efésio. Ao longo do tempo Heráclito continuou sendo visto como sombrio e pessimista, o que o levou a ser conhecido como O obscuro. Nietzsche discorda: "É provável que nenhum homem jamais tenha escrito 
mais clara e luminosamente que Heráclito. Ele é, decerto, bastante breve, e, justamente por isso, obscuro para o leitor-maratonista."(NIETZSCHE; 2011:71). O Heráclito de Nietzsche se encontra na fronteira entre o filósofo e o místico. Ou, caso fóssemos usar as palavras de Deleuze, Heráclito estaria entre o filósofo e o feiticeiro - aquele que habita as fronteiras, lugares de devir.

É no limite ou na fronteira entre os contrários e, mais especificamente, entre o nosso interior e nosso exterior que, de acordo com Bergson, podemos perceber tanto um lado quanto o outro. Nesse ponto em que parece que já deixamos de perceber um deles e ainda não estamos percebendo o outro, aí se forma a imagem do nada, mas que também parece ser uma imagem cheia de coisas; "[...] uma imagem que encerra ao mesmo tempo a do sujeito e a do objeto, com, além do mais, um perpétuo oscilar entre uma e outra e uma recusa de nos chegarmos a fixar definitivamente em uma delas." (BERGSON; 2010:305).

Também Bergson acreditava que a realidade, seja matéria, seja espírito, se manifesta a nós como um perpétuo devir, do qual só captamos estados (BERGSON; 2010:97-98). E ao tentarmos apreender essa realidade, muitas vezes caimos na ilusão de imaginar ser possível pensar o instável pelo estável, ou o móvel pelo imóvel. Devemos, no entanto, tentar apreendêla daquele ponto de fronteira, na instabilidade. Quando fixamos um ponto de observação acabamos tendendo para a imobilidade, formulando uma suposta situação de ausência a partir da memória de uma também suposta presença anterior. Ora, Bergson nos chama atenção ao fato de que aquilo que se percebe deve ser sempre a presença e nunca a ausência. Segundo o filósofo, se seguíssemos pura e simplesmente o fio da experiência viveríamos dentro do atual, e não haveria o vazio, o nada, mesmo relativo ou parcial, mas veríamos os fatos sucederem-se aos fatos, os estados aos estados e as coisas às coisas (BERGSON; 2010:320).

Quando trazemos à tona o papel da memória e nos apoiamos no passado, virando as costas para o presente, passamos a pensar na passagem de um estado a outro como mudança, estabelecendo um contraste entre a situação anterior e a atual. Essa atitude implica um sentimento de nostalgia que leva a uma substituição de estados em que nos interessamos pela primeira metade - o passado - por uma questão de afeição. Se suprimirmos o interesse e a afeição, o que resta é a realidade que flui e a apreensão do estado presente que ela imprime em nós, por meio da experiência.

No entanto, o que fazemos, por meio da percepção é captar uma série de mudanças elementares sob a forma de qualidades ou estados simples, tornando a matéria estável sob uma forma. Bergson afirma que, tomando como princípio a constante mudança do corpo, a forma não deveria existir, pois pertence ao mundo do imóvel, ao passo que a realidade é 
movimento. Nesse processo de buscar o ponto imóvel para apreensão de uma realidade fluida, acabamos, segundo o filósofo, criando três espécies de representações: qualidades, formas ou essências e atos. Cada uma dessas representações corresponderia a uma categoria de palavra, respectivamente: adjetivos, substantivos e verbos. Nossa percepção busca extrair, dessas três formas de devir, um devir geral, indeterminado, sobre o qual é difícil estabelecermos algum pensamento. Acabamos retendo não esse aspecto geral, mas a multiplicidade de formas, qualidades e atos.

Ao invés de vivenciar a mudança, buscando experimentar o devir interior das coisas, colocamo-nos fora delas, acionando uma espécie de cinematógrafo interior, o que constituiria um método cinematográfico de percepção da realidade, como afirma Bergson. A aplicação desse método leva a uma dinâmica em que nunca conseguimos apreender a realidade geral ou em devir, e acabamos insatisfeitos — o que nos leva a recomeçar o processo.

Esse movimento de perpétuo recomeço muitas vezes nos faz confundir nossa própria instabilidade com o movimento real do devir. No entanto, esse processo carece da vivência, de uma inserção no devir mesmo, em que olhamos para a mudança de dentro dela, e não por seus estados sucessivos nos quais ela poderia se imobilizar a cada instante. Heráclito e Nietzsche também davam grande importância à dimensão da experiência: "Em Heráclito (e em Nietzsche) não há razão sem ação, não há teoria sem prática, verdade sem vida." (OLIVEIRA:2010). Segundo Bergson, a experiência é que nos coloca na presença de um devir.

A percepção pelo método cinematográfico bergsoniano acaba por reduzir as coisas às ideias, destacando apenas momentos principais, rejeitando o movimento em si. Às ideias é necessário acrescentar o vazio, o nada, na busca por refratar a ideia imóvel e simples em um movimento indefinidamente propagado - o fluxo de um devir universal (BERGSON; 2010:345). Para Bergson, a posição de uma realidade implica a posição simultânea de todos os graus de realidade intermediários entre ela e o puro nada (BERGSON; 2010:352). Encontramos aí, na filosofia bergsoniana, portanto, alguma reverberação das noções contidas na concepção de ser e devir em Hegel.

À ciência, tanto para Hegel, quanto para Nietzsche e Bergson, escapa o tempo real - ou a mobilidade do ser — , encarado como fluxo. Os três filósofos defendiam um método que levasse em conta tanto a intuição quanto a experiência como forma de inserção no devir. Isso porque, como defende Bergson, as coisas não se dão de uma vez, no sentido de que a cada momento presente são determinadas certas realidades intrínsecas a esse momento, pois nele se 
cria incessantemente algo imprevisível e novo. "A duração do universo deve constituir uma unidade com a latitude de criação que nele pode haver.” (BERGSON; 2010:369).

Quando habitamos o interior do devir, abolindo os momentos de tempo, encontramos a duração real e a verdadeira criação (BERGSON; 2010:373). Por isso que, para o artista, segundo Bergson, o tempo da invenção identifica-se com a própria invenção. Nietzsche também enxergava no devir a atitude estética diante do mundo, existente também no jogo do artista e da criança, cujas ações envolvem um contínuo criar e destruir. O filósofo alemão retoma, a partir dessa postura, a conduta de Heráclito, que "descreve apenas o mundo existente, e tem nele o prazer contemplativo do artista que observa sua obra em formação.” (NIETZSCHE; 2011:71). É também no fazer do artista que Deleuze acredita se desencadearem devires.

Ele enxerga no devir um rizoma. Para além de uma simples correspondência de relações, o devir é um sistema aberto que constitui uma multiplicidade em constante transformação. Para atingir o devir devemos pensar nos intervalos. Uma linha de devir não se define pelos pontos, mas passa entre eles; ela se define pelo meio ou pela relação. A linha do devir constitui uma zona de indiscernibilidade que não se apega à memória ou a uma duração linear do tempo - como também afirmava Bergson. O devir libera a linha, cria o rizoma.

O devir tampouco é uma semelhança ou imitação. Ele se constitui, na concepção deleuziana, por alianças (DELEUZE, GUATTARI; 1997:19). Como quando um escritor, por exemplo, vivencia o devir ao se aliar a seu personagem, pela experiência de tornar-se o próprio personagem durante o processo criativo de escrita, mais do que apenas se relacionar com ele de uma posição externa, apenas como observador. Essa dinâmica é criadora, não apenas por sua característica intrínseca que perpassa o processo criativo, mas também porque ela cria o próprio devir: “o devir não produz outra coisa que ele próprio." (DELEUZE, GUATTARI; 1997:18).

Devido ao caráter relacional, múltiplo e instável, o devir costuma se constituir de híbridos. Deleuze recorre aos devires-animal do homem para compreender melhor esse sistema. O filósofo parece apontar aí a entrada no domínio do impetuoso, sem controle e quase visceral, em que a aliança procura ser estabelecida com o anômalo - na tentativa de vivenciar algo oposto do que se é na aparência. Para Deleuze o anômalo, diferentemente do anormal (definido em função de características específicas ou genéricas), "é uma posição ou conjunto de posições em relação a uma multiplicidade. [...] É sempre com o anômalo que se faz aliança para devir-animal.” (DELEUZE, GUATTARI; 1997:26). O anômalo constitui um fenômeno de borda (ou fronteira), medido mais pela dimensão de sua intensidade do que pela 
extensão de suas caracterísitcas. Estar na fronteira propicia ao anômalo integrar relações ou alianças, como prefere Deleuze - o que amplia as possibilidades de devires. O elemento anômalo assume seu caráter instável e múltiplo e se torna, no curso de suas relações, um todo momentâneo, sem começo nem fim, sem origem nem destinação, que ganha sentido no entre. Essa dinâmica, portanto, constitui o sistema aberto do rizoma, como afirmamos acima; um sistema formado não de pontos, mas de linhas (relações).

Deleuze também ressalta o caráter molecular do devir, como se estivéssemos mergulhados em um constante estado de simbiose potencial, em que, de acordo com os movimentos e velocidades das relações, pudéssemos nos tornar, ao rearranjar as partículas aí existentes, em algo que outrora não vivenciávamos:

Devir é, a partir das formas que se tem, do sujeito que se é, dos órgãos que se possui ou das funções que se preenche, extrair partículas, entre as quais instauramos relações de movimento e repouso, de velocidade e lentidão, as mais próximas daquilo que estamos em vias de nos tornarmos, e através das quais nos tornamos. É nesse sentido que o devir é o processo do desejo. (DELEUZE, GUATTARI; 1997:64)

Deleuze não fala em formas, mas em coletividades moleculares de aspectos inseparáveis que ora se configuram de um modo, ora de outro, conforme essas alterações de movimento e velocidade, como também acreditava Giordano Bruno. O devir-animal do homem nos joga no campo do descontrole e do desejo assim como o devir-mulher, abordado pelo filósofo ao refletir sobre essa experiência. Ele traz o exemplo de Virginia Woolf que, perguntada acerca de uma escrita feminina responde dizendo que, antes de tudo, ao se pensar uma suposta escrita feminina, é preciso que a escrita produza um devir-mulher, "com átomos de feminilidade capazes de percorrer e de impregnar todo um campo social, e de contaminar os homens e torná-los num devir" (In: DELEUZE, GUATTARI; 1997: 68).

Quando a escritora revela a alma feminina, não a faz com fins de identificação e semelhança, mas sim a partir de uma vivência que proporcione ao leitor uma experiência de devir-mulher, mesmo para as próprias mulheres. Tomemos o exemplo da música Olhos nos $\operatorname{Olhos}^{37}$, de Chico Buarque. Ao executá-la, o cantor atinge um devir-mulher tal que nem

\footnotetext{
${ }^{37}$ Nos dois videos que citamos adiante e que se encontram no DVD em anexo vemos, em um deles, Chico Buarque e Maria Bethânia comentando sobre a música e fazendo suas interpretações. Em outro video Chico fala brevemente sobre sua relação com o universo feminino. Vale ressaltar, no vídeo que traz a fala de Maria Bethânia, que com a interpretação dessa música a cantora relata ter conseguido sucesso pela primeira vez nas rádios AM, atingindo um público diferente daquele acostumado a ouvir MPB, pertencente a classes mais altas, ouvinte de rádios FM. Primeiro vídeo disponível em:

$<$ https://www.youtube.com/watch? $\mathrm{v}=$ CP7Pxchikss $>$. Acessado em 16/09/2014. Vídeo em DVD em anexo: pasta 'Capitulo_02' $>$ 01.Chico Buarque - Olhos Nos Olhos.mp4. Segundo vídeo disponível em: $<$ https://www.youtube.com/watch?v=eOp_HFwT7eA>. Acessado em 16/09/2014. Vídeo em DVD em anexo: pasta 'Capitulo_02' >> 01a.Chico Buarque - Olhos Nos Olhos.mp4.
} 
mesmo outra mulher conseguiu. As interpretações de Maria Bethânia, por mais bem realizadas que sejam, não atingem a intensidade de Chico, que não apenas vivencia um vir-aser mulher, mas proporciona a cada ser-mulher a experiência de ser mais mulher, ou ser mulher como as outras mulheres o são.

É para essa direção que Deleuze acredita se dirigirem todos os devires: a de um devirimperceptível como fim imanente de todo devir:

É nesse sentido que devir todo mundo, fazer do mundo um devir, é fazer mundo, é fazer um mundo, mundos, isto é, encontrar suas vizinhanças e suas zonas de indiscernibilidade. O Cosmo como máquina abstrata e cada mundo como agenciamento concreto que o efetua. Reduzir-se a uma ou várias linhas abstratas, que vão continuar e conjugar-se com outras, para produzir imediatamente, diretamente, um mundo, no qual é o mundo que entra em devir e nós nos tornamos todo mundo. (DELEUZE, GUATTARI; 1997:73)

Olhos nos olhos proporciona essa experiência de reconhecimento mútuo. A sensação de pertencimento ao mundo e de compartilhamento; de comunicar-se com ele e por meio dele constitui um movimento imperceptível, que só é percebido quando reforça seu caráter de fronteira, de passagem constante entre um plano imanente e um plano transcendente. Ou seja, enquanto somos tomados pela música, tal qual uma enchente preenche todos os espaços no fluxo descontrolado por onde passa, experimentamos, sejamos homens ou mulheres, a sensação de ser-com todas as outras mulheres um estado de ser-mulher.

Habitamos esse estado em que nos sentimos parte de algo maior, de uma comunidade que se constitui nessa fronteira entre o transcendente e o imanente e aí permanecemos até que a música nos deixe - ou que a deixemos ir —, e retornamos aos nossos estados de simples homens ou mulheres, mas transformados pela experiência do devir. Segundo Nietzsche, sem essas vivências, proporcionadas geralmente pela arte, a vida se tornaria insuportável ${ }^{38}$. Em várias obras de artemídia que analisaremos nos segundo e terceiro capítulos, essas sensações de reconhecimento coletivo são experimentadas ao nos depararmos com a aisthesis proveniente de um confronto com a imensidão do espaço imaginário, construído no embate entre imagens visíveis e mentais, levando-nos a ser-um com a imagem e o mundo por ela criado. Tal vivência apaga as fronteiras entre o interior e o exterior e nos leva a uma situação que chamamos de trans-imanente, onde ressentimos o fluxo, tornando-nos parte dele.

Outra forma de fazer essa passagem, segundo Deleuze, se dá por meio dos estados alterados de consciência, em que habitamos a fronteira entre o consciente e o inconsciente. Nesse momento, segundo ele, desejo e percepção se confundem, e o imperceptível torna-se

\footnotetext{
${ }^{38}$ Pensamento elaborado por Nietzsche no texto “A arte em 'O Nascimento da Tragédia'”(1888), In: NIETZSCHE;1999:50
} 
percebido. Adentramos o plano do inconsciente por estados de transe, quando estamos em situações-limite ou quando nos deixamos levar por emoções e pelo desejo: o risco, o fruir artístico, o gozo, a embriaguez, entre outros. Em todas essas situações vivenciamos uma experiência de descontrole, de deixar-se levar, tal qual um corpo carregado pelo rio que segue seu fluxo e, sem lutar contra a corrente, torna-se parte do mesmo rio, experimenta a mesma violência, os mesmos meandros ${ }^{39}$ e obstáculos que sofre a água que lhe serve de transporte e ao mesmo tempo o inunda.

Ao trazer essa compreensão do devir para uma observação da arte — ou da artemídia, como propomos nessa pesquisa —, fazemos uma relação com a experiência do participador que, imerso na obra, torna-se parte dela e apenas nessa aliança é que a obra ganha sentido. Além dos processos híbridos que formam a obra, ela se constitui também, por sua vez, num híbrido juntamente com o participador. Ao analisarmos a obra de artemídia, só o podemos fazê-lo, realmente, pela intuição e pela vivência de um ponto de vista interno. E, fazendo parte dessa relação, ou aliança, devemos levar em conta que as linhas que estabelecem essas ligações não são linhas que ligam pontos, mas linhas que passam entre os pontos, como relembra Deleuze: "O devir é um movimento pelo qual a linha libera-se do ponto, e torna os pontos indiscerníveis: rizoma.” (DELEUZE, GUATTARI; 1997:91).

Nossa análise, portanto, depende de um mergulho intuitivo num sistema multilinear, em que as linhas estão liberadas dos pontos e de outras linhas e são fluidas. Tal qual nos deixamos des-guiar pelas linhas "geométrico-curvas" de Miró ou Kandinsky, pelas nuances de cor que criam zonas fronteiriças de não-limite na obra de Cézanne ou ainda pelos pontoslinhas que se tornam um só nas pinturas de Pollock, também nós, muitas vezes, nos tornamos linha que ressignifica outras linhas e pontos em movimento ao nos inserirmos na obra de arte contemporânea, numa dinâmica em que a arte se completa mediante essa relação.

Deleuze atualiza o pensamento do devir, a partir de um diálogo com Bergson, ao constituir as categorias de imagem-movimento e imagem-tempo na análise cinematográfica. Essa transposição nos serve como guia para pensar a aplicação do pensamento sobre o fluxo à observação do nosso objeto, de modo a compreender a estética daí resultante, tendo em vista que a artemídia, ao se apropriar principalmente do recurso da projeção, dialoga diretamente com a técnica cinematográfica e suas implicações estéticas, não se restringindo a ela,

\footnotetext{
${ }^{39} \mathrm{Na}$ Turquia existe o rio Büyük Menderes que significa "grande meandro". Ele percorre aproximadamente $500 \mathrm{Km}$ no sudeste do país, onde antes se encontrava a região (então grega) de Éfeso, terra natal de Heráclito.
} 
obviamente, visto que estende suas fronteiras de linguagem em direção ao hibridismo com outras linguagens e meios (no caso, meios de comunicação, em sua maioria).

Deleuze, tal qual Bergson, acredita que o movimento não pode ser compreendido por cortes imóveis, instantes ou posições dentro de uma perspectiva cronológica de tempo. Para ambos, estamos imersos em uma matéria-fluxo em constante mudança, constituída segundo a relação imagem = movimento (DELEUZE; 2009:96). Essa relação, por sua vez, cria uma espécie de plano de imanência em que "a imagem-movimento e a matéria-fluxo são estritamente a mesma coisa." (Ibidem:97). Ao estarmos imersos no movimento constante da duração, só podemos percebê-la e, consequentemente, participar e compreender o fluxo das coisas, a partir do "distanciamento imersivo" proporcionado por uma imagem que a represente, ou seja, que não se desvincule da sua essência movente — da duração e da própria imagem.

Nesse cenário, Deleuze afirma ser o plano de imanência constituído pela luz: "A identidade da imagem e do movimento tem por razão a identidade da matéria e da luz. A imagem é movimento como a matéria é luz.” (Ibidem:99). Dessa forma, Deleuze concebe um estado de imersão nas imagens, que se configuram como imagens-movimento constituídas de luz. Essa afirmação nos chama especial atenção, tendo em vista a predominância da luz na constituição das imagens de nosso objeto de estudo.

Ao analisar o cinema francês o autor destaca como a luz, nesse contexto, cria formas luminosas pela sua própria mobilidade, mais até do que pelo encontro com os objetos que se deslocam (DELEUZE; 2009:75). Segundo ele, a imagem-movimento cinematográfica "extrai dos movimentos a mobilidade que é a sua essência." (Ibidem:44). Dessa forma, destacamos aqui a principal característica dessa imagem-movimento: ela permite realizar um corte móvel da duração ${ }^{40}$.

A partir daí, a grande dificuldade em aplicar essa categoria de imagem consistiria na apreensão da duração ${ }^{41}$ como um todo pois, devido a sua natureza móvel, ela se constituiria naturalmente como um sistema aberto. A dimensão desse todo em constante mudança, ou de um "devir universal”, como propõe Deleuze (2009:111), seria alcançada apenas mediante a abordagem do aspecto da relação entre sujeito e objeto nessa dinâmica (Ibidem:25).

\footnotetext{
${ }^{40}$ Deleuze concebe a duração a partir do pensamento bergnoniano, principalmente nas ideias desenvolvidas em $A$ evolução criadora: "Se nossa existência fosse constituída por estados separados cuja síntese teria de ser feita por um 'eu' impassível, não existiria para nós duração. [...] Em vão se alinharão esses estados uns ao lado dos outros sobre o 'eu'que os suporta, jamais esse colar de sólidos poderá constituir uma duração que flui. [...] nossa duração não é um instante que substitui outro instante: se assim fosse, não haveria outra coisa senão o presente, não haveria prolongamento do passado no atual, não haveria evolução nem duração concreta."(BERGSON;2010:18).

${ }^{41}$ Conceito que entendemos também como fluxo.
} 
A imagem-movimento, apesar de realizar um corte móvel na duração, não consegue abarcá-la em sua totalidade, pois não engloba a perspectiva da relação. Deleuze fala sobre as manifestações dessa imagem-movimento seja pela imagem-percepção, imagem-ação ou imagem-afecção ${ }^{42}$, no entanto, o aspecto relacional só aparece no momento em que ele aborda a imagem mental pelo ponto de vista da Tercidade, de acordo com o pensamento semiótico pierciano (Ibidem:289). Enquanto a imagem-afecção se ligaria à Primidade (ou à dimensão icônica), e a imagem-ação à Segundidade (ou dimensão indicial), a imagem mental se ligaria ao elemento simbólico presente na Tercidade:

não percepções, mas interpretações que remetem para o elemento do sentido; não afecções, mas sentimentos intelectuais de relações. [...] É talvez na relação que a tercidade encontra a sua representação mais adequada; porque a relação é sempre terceira, sendo necessariamente exterior aos seus termos (DELEUZE; 2009:289-290).

A imagem-afecção e a imagem-ação, segundo Deleuze, já comportavam algo de mental, mas isso não fazia do mental, nesse caso, o objeto de uma imagem, ou seja, não tornava possível "uma imagem que toma por objetos de pensamento objetos que têm uma existência própria fora do pensamento. [...] Uma imagem que toma por objeto relações, atos simbólicos, sentimentos intelectuais." (DELEUZE; 2009:291). Mesmo assim, a imagem mental, apesar de tangenciar o aspecto relacional, ainda não seria capaz, segundo Deleuze, de perceber a duração em sua totalidade. Para isso, "era preciso que a imagem mental não se limitasse a tecer um conjunto de relações, mas formasse uma nova substância [...], que ela se fiezesse verdadeiramente pensamento e pensante" (Ibidem: 314), que se direcionasse para além do movimento. Dessa forma, o autor propõe uma imagem-tempo, ou imagem-duração, que extrapolaria a imagem-movimento.

A imagem-tempo se constitui na relação entre as virtualidades e atualidades da própria imagem. Ao se atualizar, ela não perde sua virtualidade, mas existe entre esses dois estados (Ibidem:70). A sensação de dèjá-vu ou as imagens de sonho, alucinação e delírio abordam a experiência intrínseca à imagem-tempo, pois elas se manifestam, em geral, numa situação de confusão de memória, quando a imagem atual, percebida pelos sentidos, não se encadeia com uma imagem virtual correspondente e, portanto, permanece no limite entre um e outro. Nesse ponto se estabelece uma relação de aderência da imagem atual à virtual formando uma

\footnotetext{
42 Discorreremos brevemente sobre as categorias desenvolvidas por Deleuze: A imagem-percepção, seria aquela que subtrai da coisa observada aquilo que se destaca na observação, segundo critérios subjetivos, priorizando a variável espacial (2009:104). A imagem-ação, por sua vez, contempla a ação virtual das coisas sobre nós e nossa ação possível sobre as coisas, ressaltando a variável temporal (Ibidem:106). Já imagem-afecção, ocuparia o intervalo entre as imagens perceptiva e ativa, representando um centro de indeterminação em que o sujeito (aquele que percebe e age) e objeto (aquele que sofre a ação) se misturam (Ibidem:idem).
} 
imagem bifacial, em que se percebe uma indiscernibilidade entre o real e o imaginário. Deleuze denomina essa imagem também como imagem-cristal (DELEUZE; 2009:88).

O cristal revela uma imagem-tempo direta, e não mais uma imagem indireta do tempo, que decorresse do movimento. Ela não abstrai o tempo, faz melhor, reverte sua subordinação em relação ao movimento. [...] O que o cristal revela ou faz ver é o fundamento oculto do tempo, quer dizer, sua diferenciação em dois jorros, o dos presentes que passam e o dos passados que se conservam. De uma só vez o tempo faz passar o presente e o conserva em si o passado (DELEUZE; 2009:121)

Nesse caso, a imagem constitui algo novo, concebido na relação entre as imagens potenciais e aquela que se apresenta finalmente, num híbrido desses dois estados que, momentaneamente, se mostra segundo uma de suas possibilidades de manifestação — uma manifestação oscilante que constitui as topologias imaginárias sobre a qual falaremos no terceiro capítulo a partir da experiência perceptiva das obras de artemídia contemporânea, quando nos referiremos ao devaneio. De acordo com Deleuze, assim também se comporta a obra de arte que, como o cristal, converge ao mesmo tempo as duas imagens, por sua vez distintas e indiscerníveis, que habitam as esferas virtual e atual que a contém. É na corrente do devir que o artista atua, em plena transformação: "Há um ponto de vista que pertence tão bem à coisa que a coisa não para de se transformar num devir idêntico ao ponto de vista. [...] $\mathrm{O}$ artista é criador da verdade, pois a verdade não deve ser alcançada, encontrada nem reproduzida, ela deve ser criada.” (2009:178).

Acreditamos que essa categoria da imagem-tempo, ou imagem-cristal, também é a que mais se aproxima das imagens impalpáveis da artemídia que iremos analisar: imagens de luz, tais como as que Deleuze atribui à imagem movimento, mas que ultrapassam as imagensmovimento por sua imaterialidade constitutiva, ao se apropriarem de recursos de projeção e assumirem a característica da transparência: “A projeção, a transparência são apenas meios técnicos que levam diretamente à imagem-tempo, substituem a imagem-movimento pela imagem-tempo" (DELEUZE; 2007:314).

Após essa investigação que tem como ponto de partida as noções de Heráclito acerca do fluxo, podemos ressaltar como importantes contribuições para a observação das obras de artemídia e reconhecimento das manifestações de fluxo como estética, a ideia relacionada à harmonia entre contrários, que reverbera também em Nietzsche; a da unidade do tudo-um com repercussões em Giordano Bruno e Deleuze; de fronteira ou passagem entre o interior e o exterior, como visto em Bergson, e como veremos mais à frente, ao introduzirmos o conceito de dobra em Deleuze. Aliás, é em Deleuze que encontramos reverberações mais 
contemporâneas e que se aplicam à experiência com nosso objeto de pesquisa, principalmente no que diz respeito à noção de rizoma, de imagem-cristal e de devir, ou devires, visto que esse(s) pode(m) se manifestar de diversas formas, muitas delas tendo como ponto de chegada o devir-imperceptível que remete ao reconhecimento mútuo numa vivência coletiva, no sentido heraclitiano de coletividade originária (logos), caracterizada pela busca transimanente do estar-junto, como veremos nos capítulos a seguir. 
3.

\section{Oscilações da Imagem: ritmo e hibridismo na percepção do devir}

Uma importante característica da imagem-tempo, sobre a qual nos fala Deleuze é justamente o seu estado de contínuo devir, de permanecer entre as diversas possibilidades de atualização e uma momentânea atualidade. É uma imagem que se constitui não apenas por seu aspecto móvel, mas também por seu caráter multidimensional. Nos interessamos especialmente pelo entre, esse intervalo que viabiliza a passagem de um estado a outro. Aí encontramos uma manifestação do fluxo. Essas imagens se apresentam, muitas vezes, por meio da luz, fazendo uso do recurso do projetor, tão presente nas obras de artemídia.

Apesar da característica luminosa e da primeira impressão que temos de que um feixe de luz se apresenta de forma contínua, percebemos, sob um olhar mais cuidadoso, que essa imagem é, em verdade, intermitente, tal como a imagem dos primeiros projetores do início do cinema. E precisa sê-lo, pois em sua constituição ela carrega o intervalo, o entre, que propicia o estabelecimento de relações. Essa, portanto, é uma imagem que se caracteriza pela oscilação, um aspecto que salientamos para compreender a constituição de uma estética do fluxo. Dessa maneira, neste capítulo procuraremos investigar como se manifesta essa oscilação e como ela é percebida, buscando entender o impacto desse aspecto no fluxo entre imagem e sujeito, ou obra e participador.

Karl Sierek em seu livro Les images oiseaux. Aby Warburg et la théorie des médias (2009:135) comenta que, para Warburg, a oscilação da imagem é fruto de suas energias contraditórias - assim como se dá na harmonia entre contrários do fluxo heraclitiano formando um campo energético bivalente que constitui a imagem e que se alterna ritmadamente entre luz e sombra e, acrescentamos, também entre real e virtual. Essas imagens são muitas vezes precárias, fluorescentes, vacilantes e indeterminadas (Ibidem:136). Se ligam às imagens de sonho, nebulosas e indefinidas. E, assim como elas, formam uma categoria de sobrevivência, como denomina Warburg, “[...] hesitando entre presença e ausência, as imagens integram isso que é e isso que foi, no instante do olhar, e revelam figuras que pertencem a esse reino intermediário: um mundo de fantasmas" (Ibidem:76).

Nas obras de artemídia essa imagem surge da sombra por meio de pontos cintilantes ou de feixes luminosos descontinuados, criando espaços imateriais de interação momentânea com o participador, estimulando uma relação entre a imagem técnica, não tão nítida, que 
surge do escuro, e aquela que surge, também não tão distinta, das sombras da mente, completando o diálogo. Indiscernibilidade que leva a um transitar displicente entre diferentes categorias de imagens impalpáveis, como na obra Exploded View (Commuters) (2011) ${ }^{43}$, de Jim Campbel1 ${ }^{44}$, percorrida em julho de 2012 no Instituto Itaú Cultural em São Paulo durante a $6^{\text {a }}$ Bienal Internacional de Arte e Tecnologia - Emoção Art.Ficial.

Aqui o artista cria uma matriz tridimensional escultórica, composta por mais de mil lâmpadas de LED brancas penduradas. O espaço destinado à obra é escuro, dando destaque aos pontos de luz oscilantes e suspensos que, à primeira vista, se assemelham a uma constelação de estrelas - constituindo uma possibilidade visível da metáfora do campo energético de Warburg, sobre o qual falamos anteriormente. No entanto, conforme nos aproximamos da obra, o que parece ser um piscar de luzes aleatório pouco a pouco revela uma imagem em movimento, não nítida, que se desloca, mostrando vultos de pessoas que surgem da sombra em que estamos inseridos.

Somos convidados a também nos deslocarmos ao redor da obra, a desvendá-la, a procurar o ponto de vista ideal para entender a imagem que se forma ali. À medida que nos encontramos com esses vultos e em seguida os perdemos nos espaços entre uma lâmpada e outra, ou no continuar de sua caminhada para fora da suposta tela, vamos penetrando a sombra por meio de uma percepção não apenas física, mas sensorial e estética. Ao circular ao redor da obra experimentamos a leveza de também nos desintegrarmos em pequenos pontos de luz ou nos intervalos entre as luzes pênseis, como se a percepção se expandisse, ou explodisse, como propõe o artista, num devir luz e sombra em que a forma em si não interessa mais, mas ganha a dimensão da experiência por meio da percepção.

\footnotetext{
${ }^{43}$ Disponível em: < http://vimeo.com/32023023 > . Acessado em 30/01/2014. Vídeo em DVD em anexo: pasta“Capitulo_03’ $>$ 01.ExplodedViews.mp4

${ }^{44} \mathrm{Jim}$ Campbell (1956 - ). Site do artista: http://www.jimcampbell.tv/
} 


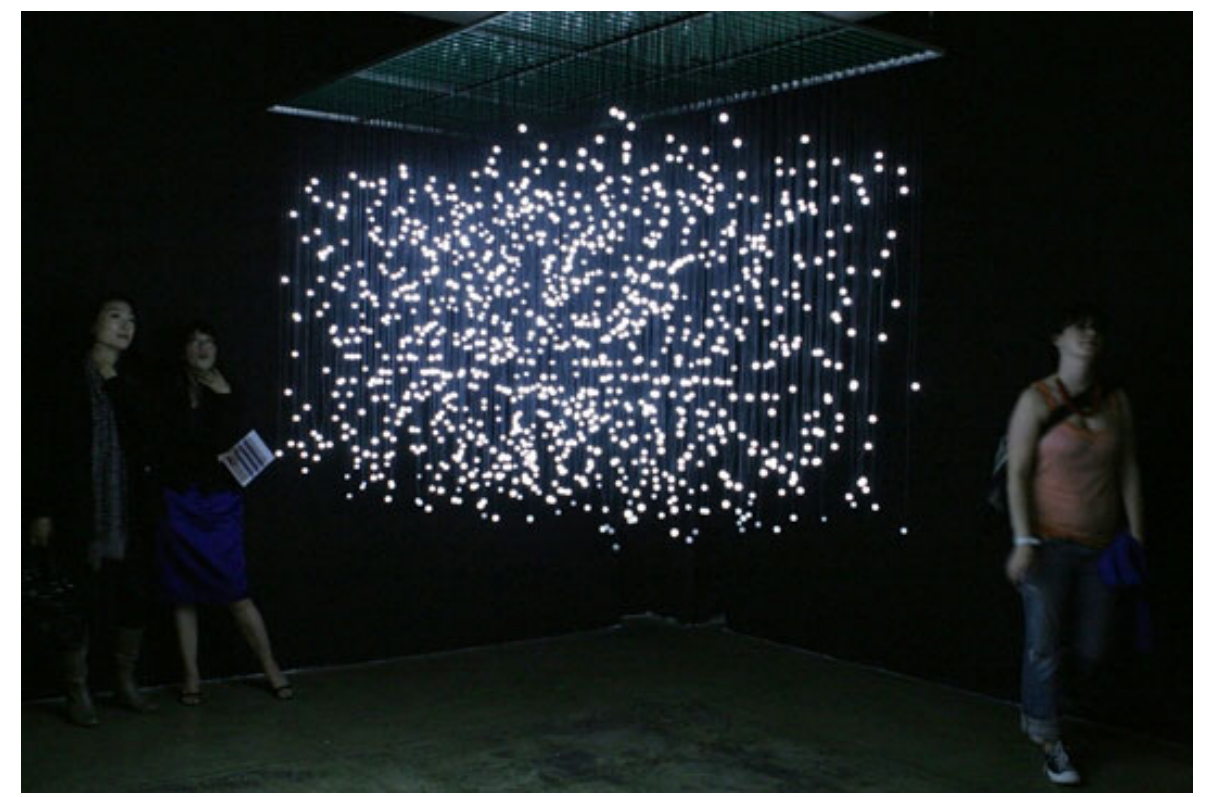

Figura 1: Exploded View (Commuters) (2011), Jim Campbell

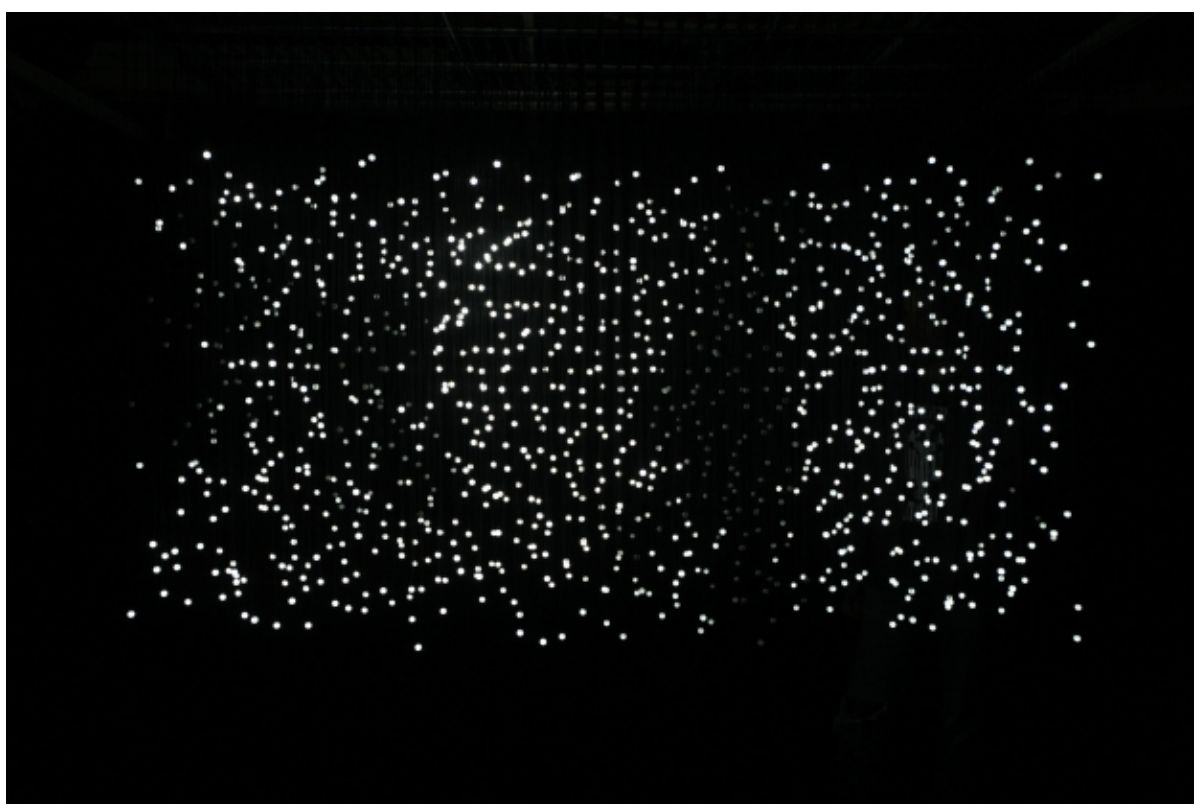

Figura 2: Exploded View (Commuters) (2011), Jim Campbell numa visão que se assemelha a uma constelação de estrelas

Sujeito e obra fundem-se e alternam-se a partir do momento em que a obra nos proporciona a sensação de fragmentação por meio da relação entre sua imobilidade, que em si carrega uma imagem móvel, e de nosso transitar ao redor dela. Uma relação que destaca, ainda, seu aspecto híbrido, ao evidenciar o diálogo entre a escultura, o cinema e o vídeo: tela tridimensional de imagens não nítidas. A partir da oscilação de linguagens e também entre os pontos luminosos e escuros, bem como dos diferentes estados de movimento, experimentamos uma vivência do fluxo que só é possível no entre, numa sensação de suspensão e flutuação e de fazer-parte: devir um só com a obra. 
Sierek destaca que, para Warburg, as imagens que constituem essas obras podem ser compreendidas como espaços de pensamento, que "[...] nascem da distância entre o eu e seu ambiente, mas vai, em seguida, se acomodar na imagem quanto energia instrumental." (SIEREK, 2009:133). Essas imagens energéticas acabam por se tornar cada vez mais líquidas e opacas, transitando entre os diferentes níveis de realidade e se afastando da sua transparência representacional, como também aponta Warburg. Nesse ponto, a imagem se transforma, segundo o autor, num comutador social pois existe interação entre essa e quem a olha, tal qual na obra que acabamos de analisar - Exploded View (Commuters).

Esse aspecto divergente é mais característico da imagem eletrônica; a imagem clássica tendia à convergência (DELEUZE apud SIEREK, 2009:139). Dessa forma, torna-se possível a multiplicação de parâmetros, o que resulta em mais oportunidades de modulação de ordem espaço-temporal, dissolvendo as fronteiras entre o atual e o virtual. Aproximam-se, dessa forma, a ideia de oscilação em Warburg e a de imagem-tempo, ou imagem-cristal em Deleuze. No âmbito da experiência na artemídia, essa alternação se dá, ainda, entre as imagens propostas pela obra e as imagens de pensamento - ou imagens mentais — criadas pelo participador no momento da interação, gerando uma imagem não só impalpável como visível apenas àquele que vivencia a experiência da obra, sendo invisível aos demais. Cada interação dá origem, portanto, a uma imagem-cristal única e efêmera.

Em uma obra apresentada no Festival Némo ${ }^{45}$, realizada no Espace Centquatre em Paris, em 2013, pudemos experimentar a sensação de uma percepção híbrida, construída nesse embate das imagens oferecidas pela obra e aquelas que habitam a mente, por sua vez também tão indistintas quanto a imagem oscilante warburguiana. Infinity III $(2012-2013)^{46}$ de Hee Won $\mathrm{Lee}^{47}$, é uma videoinstalação em que são projetadas imagens em movimento de pontos de luz na parede e no chão, procurando criar uma sensação de imersão no participador a partir da apropriação de duas dimensões do espaço. Mais uma vez adentramos a caverna escura da obra, onde as luzes do projetor ganham destaque. Ao entrar, a primeira percepção é de pontos luminosos piscando, de forma bem semelhante à obra citada anteriormente, formando um céu de estrelas, porém num ritmo mais forte.

\footnotetext{
${ }^{45}$ Site do festival: $<$ http://www.arcadi.fr/evenements/festival-nemo/ $>$

${ }^{46}$ Disponível em: < http://vimeo.com/81414949 > Acessado em 30/01/2014. Vídeo em DVD em anexo: pasta 'Capitulo_03'

$>$ 02.InfinityIII.mp4

${ }^{47}$ Hee Won Lee $(1978-$ ). Site da artista: $<$ heewonlee.com $>$
} 


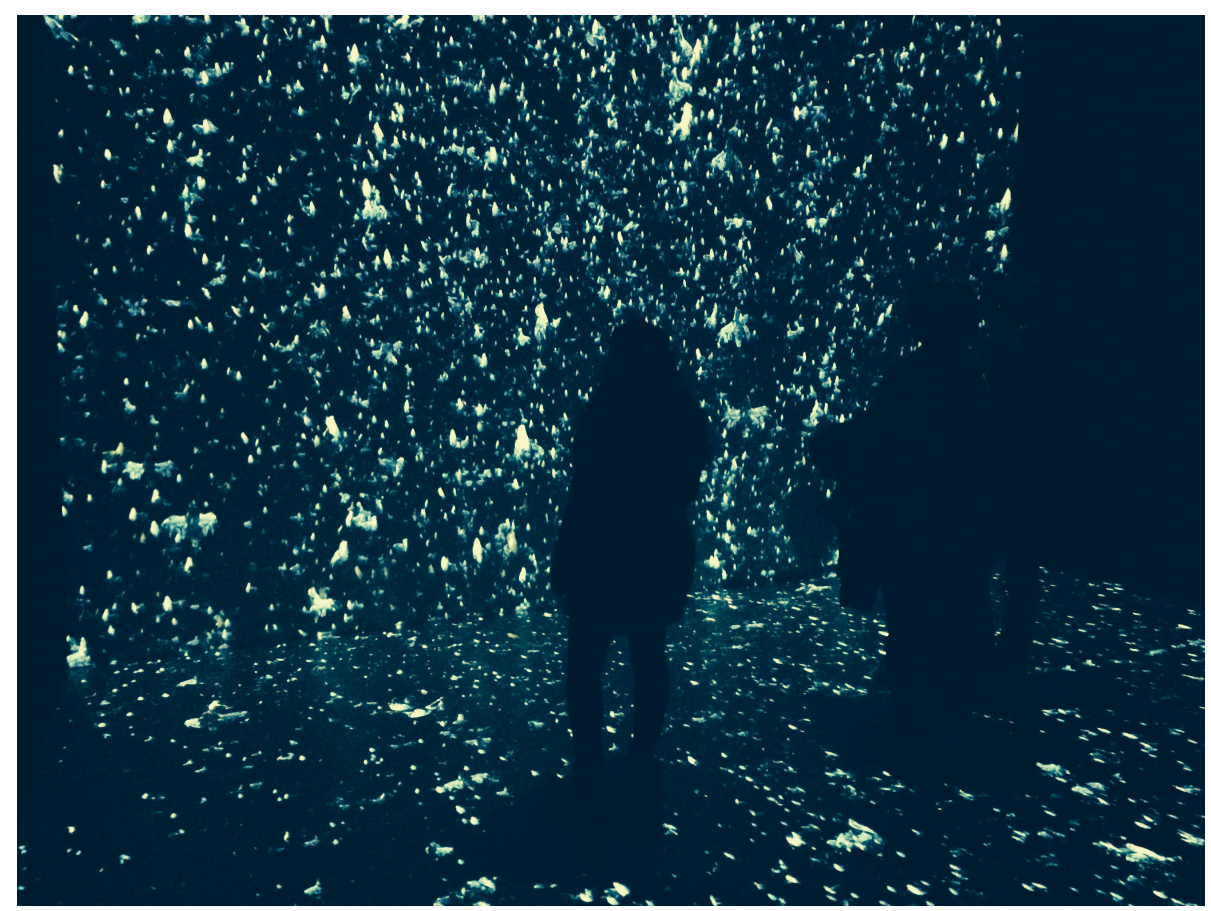

Figura 3: Infinity III (2012-2013), Hee Won Lee numa visão que também se assemelha a uma constelação de estrelas cuja disposição provoca a sensação de imersão

O impacto do som também é bastante perceptível no primeiro contato, pois esse se manifesta como uma onda, criando uma espécie de vibração sonora que nos insere ainda mais no contexto desejado pela artista. À medida que nos instalamos em meio à obra, percebemos que esses pontos são vetores gráficos que representam pássaros migratórios virtuais que passam, ora em bando, preenchendo todo o espaço da projeção, ora isolados, um aqui, outro acolá, dando destaque ao espaço da sombra e abrindo tempo para contemplação, segundo propõe a artista. O som ritmado nos remete ao bater de asas de pássaros bem como aos intervalos entre sobrevoos de grupos de aves desse tipo. Por vezes o volume do som aumenta, acompanhado por uma aceleração no movimento dos pontos brilhantes. Aqui, a oscilação visual é acompanhada de uma oscilação sonora. Nos momentos de vertigem, o volume é alto, o ruído se intensifica. Nos momentos de tranquilidade, dá-se o contrário, o que intensifica a percepção espaço-temporal da instalação: “[...] em Infinity III quero levar o espectador a uma experiência espaço-temporal desestabilizante, mesmo perturbadora, à imagem daquilo que a natureza tem de vertiginoso." 48

A experiência proposta pela artista parte da sinestesia à cinestesia, ou seja, promove um estímulo sensorial para chegar a uma experiência física, corporal, inserida no tempo e espaço da obra. O gatilho para o aspecto perturbador pode variar conforme o participante. Seja a vertigem provocada pela velocidade das imagens e do piscar de luzes, ou o estranhamento de

\footnotetext{
${ }^{48}$ Disponível em: http://heewonlee.com/site.html. Acessado em 30/01/2014.
} 
um som ritmado, sintético e eletrônico que por vezes soa em alto volume, ou ainda a combinação dos dois. Segundo Merleau-Ponty, muitas vezes torna-se difícil limitar a experiência sensorial a um único registro e espontaneamente ela transborda para todos os outros sentidos.

Neste nível, a ambiguidade da experiência é tal que um ritmo auditivo faz
imagens cinematográficas se fundirem e dá lugar a uma percepção de
movimento, quando sem apoio auditivo a mesma sucessão de imagens seria
muito lenta para provocar o movimento estroboscópico. Os sons modificam
as imagens consecutivas das cores: um som mais intenso as intensifica, a
interrupção do som as faz vacilar, um som baixo torna o azul mais escuro ou
mais profundo. (2011:305)

Assim, a experiência sensorial da obra fortalece seu caráter oscilatório em que se abrem espaços para trânsitos de sentidos, percepções e significados. É provável que para grande parte do público espectador da obra — assim como aconteceu comigo —, a sensação de estar em meio a uma revoada de pássaros tenha estimulado, ainda, a retomada de uma sensação semelhante relacionada a uma imagem que já faz parte do imaginário cinematográfico e cultural do século XX: o ataque de pássaros à personagem Melanie Daniels no filme de Hitchcock (1963). Por várias vezes, quando o som aumentava, acompanhado da intensificação do movimento dos pássaros cintilantes, tem-se a vontade de levar as mãos ao rosto, tal qual faz Melanie no filme. Foi até mesmo possível presenciar, num desses momentos, uma mãe se aproximando do filho pequeno, passando um dos braços em frente ao seu rosto. 


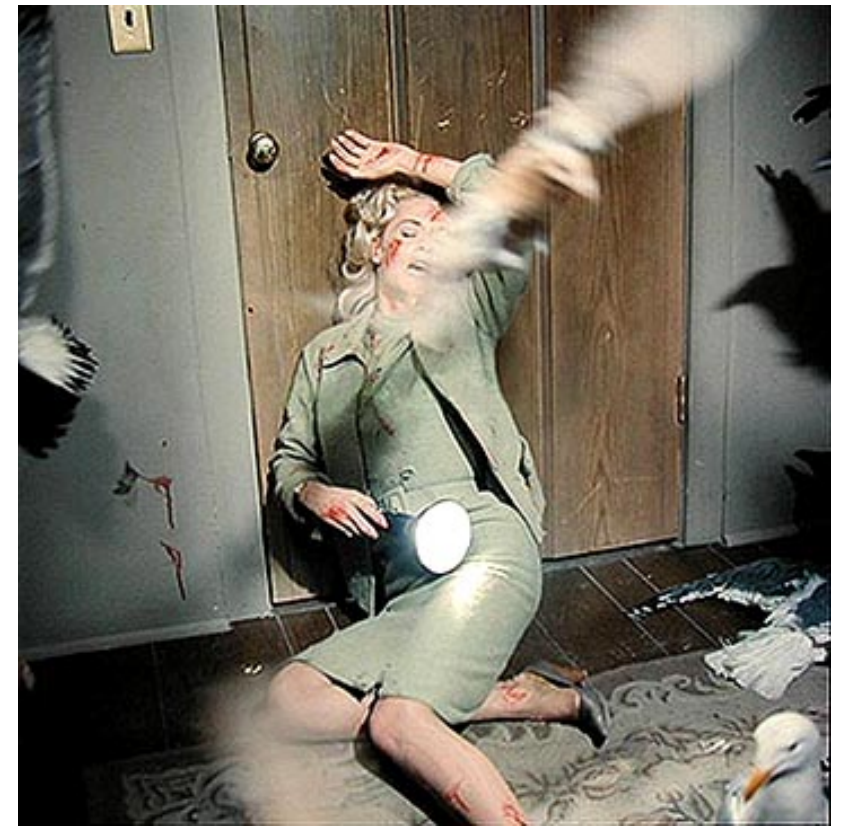

Figura 4: Cena do filme Pássaros (1963)

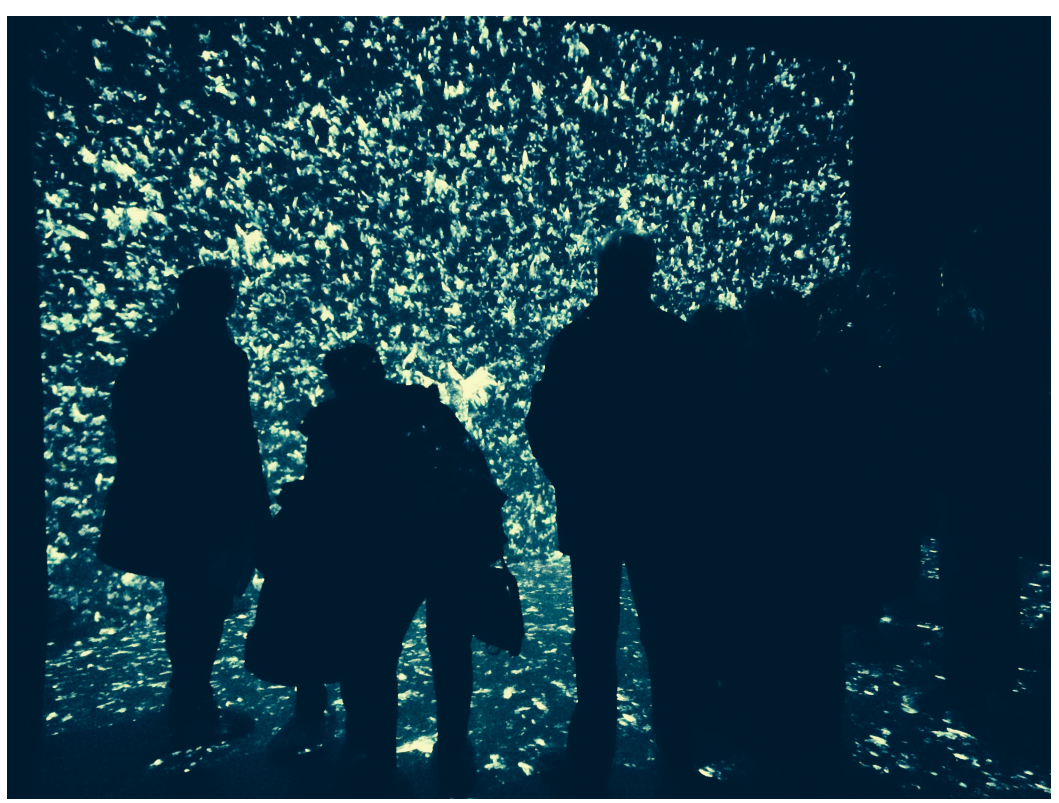

Figura 5: Mãe se abaixa para abraçar e proteger o rosto do filho ao participar da obra Infinity III (2012-2013)

Sierek aponta ainda que, segundo Warburg, a imagem possui uma mobilidade histórica, percebida nos momentos de suspensão em que se dá um intervalo de transformação da energia cinética da imagem a uma estática vibrante. Esse é o momento da experiência sensorial - e estética - em que se sucedem pausas oscilantes quando, então, intervém a Musa da Memória (SIEREK, 2009:182). A memória traz consigo as imagens passadas, sobreviventes, que habitam nossa mente e se misturam constantemente à nossa percepção do 
presente. Assim se forma a sensação estética, que pode ser compreendida, dentre outras formas, por meio do afeto. Para Bergson, não há percepção sem afeto (1999:60): “A afecção é, portanto, o que misturamos, do interior de nosso corpo, à imagem dos corpos exteriores”. Portanto, sem a memória, ou seja, sem a contribuição subjetiva ao processo perceptivo, teríamos apenas o objeto, ou seja, a matéria (Ibidem:74).

$\mathrm{O}$ artista, ao propor a participação do observador, apropria-se dessa dinâmica e joga com ela, mesmo que inconscientemente, no momento de pensar a experiência, "criando um universo inédito e composto por tudo que está no real ou na imaginação."(VENTURELLI, 2011:163). Em Infinity III, temos sensações que se alternam entre a calma de uma contemplação de voo de pássaros a impulsos pertubadores de cobrir o rosto em meio a uma revoada de pássaros descontrolados à la Hitchcock.

Essa oscilação entre as imagens internas e externas que se desenrola durante a percepção e dá vida à experiência estética, é caracterizada por um movimento de fronteira - tal qual existe no devir, segundo Deleuze. Devemos "estar no interior e imaginar o que está no exterior, estar no exterior e pensar o interior" (VENTURELLI, 2011:163). No contexto da sociedade da informação ${ }^{49}$ contemporânea, acabamos transitando mais à vontade entre esses limites, já que a virtualização de dados, impulsionada pela tecnologia digital, está, pouco a pouco, nos habituando a percorrer o campo da abstração, ou do não palpável. Certamente, hoje tomamos maior consciência do papel das imagens mentais na percepção dessas experiências do que séculos atrás, quando a imagem exterior se impunha de maneira predominante, sem que percebêssemos o diálogo com as imagens internas.

A virtualização digital, segundo Edmond Couchot, faz com que sujeito, objeto e imagem partilhem propriedades idênticas, abolindo as hierarquias e amplificando o hibridismo entre eles, tornando as fronteiras ainda mais fluidas, quando não abolindo-as completamente: "O sujeito não se coloca mais à distância da imagem, no face à face dramático da representação, ele mergulha nela [...] O sujeito interfaceado é, de agora em diante, mais trajeto que sujeito." (COUCHOT, 1998:229, grifo nosso).

Nesse cenário, o sujeito-eu (que Couchot chama de sujet-je), transforma-se num sujeitonós (sujet-on), buscando o que Deleuze chama de devir-imperceptível, ou devir mundo como todo mundo, sobre o qual falamos no capítulo anterior. Podemos, dessa forma, compreender como a sensação que se manifesta na oscilação característica desse tipo de experiência estética leva à busca pela coexistência ou comunhão. Sobre essa sensação, Merleau-Ponty diz:

\footnotetext{
${ }^{49}$ Sobre sociedade da informação, ver: CASTELLS, Manuel. A sociedade em rede. São Paulo: Paz e Terra, 2008.
} 
“Toda vez que experimento uma sensação, sinto que ela diz respeito não ao meu ser próprio, aquele do qual sou responsável e do qual decido, mas a um outro eu que já tomou partido pelo mundo, que já se abriu a alguns de seus aspectos e sincronizou-se a eles.” (2011:291).

Deleuze recorre ainda ao conceito barroco de dobra para se referir a essa característica dupla do sujeito, que é ao mesmo tempo um eu e um nós. A dobra "se atualiza nas dobras íntimas da alma e se efetua nas redobras que a matéria faz nascer umas das outras, sempre no exterior." (1991:51). A dobra explica a dinâmica da imagem-cristal ou da imagem tempo e torna o devir possível. A dobra é oscilação que se dá entre o interior e o exterior. Na artemídia, podemos estender sua ação a uma oscilação que se dá entre os contrários, de forma harmônica, como propõe Heráclito em relação ao fluxo.

Para manter a harmonia na passagem de um estado a outro, já que se trata de uma obra híbrida, essa oscilação deve seguir um ritmo, intrínseco a sua própria natureza e necessário à percepção daquilo que é móvel a partir da inserção no movimento em si. Para entender melhor a ontologia desse ritmo e de como nos inserirmos nele e, consequentemente, no movimento, discorreremos primeiro sobre o conceito de ritmanálise. Em seguida passaremos a uma investigação acerca do caráter híbrido da obras de artemídia, o que reforça seu aspecto oscilatório. Por fim, observaremos mais detalhadamente algumas relações, já levantadas anteriormente, e que se caracterizam como manifestações dessa oscilação — híbrida e rítmica — como a existente entre luz e sombra e entre o real e o virtual.

\subsection{Ritmanálise: uma dialética da mobilidade}

A partir dos estudos de Bachelard sobre a duração é que podemos entrar em contato com os primeiros pensamentos acerca da ritmanálise, que remontam ao filósofo luso-brasileiro Lúcio Alberto Pinheiro dos Santos, tendo em vista que seus escritos originais sobre o tema se perderam. No livro O essencial sobre ritmanálise, de Rodrigo Sobral Cunha (2012) também obtivemos contato com o pouco que se encontrou de material atribuído a Lúcio dos Santos.

Segundo Cunha (2012), o pensamento fundador da ritmanálise surge do anseio por uma compreensão do sentido convergente de certas intuições fundamentais do pensamento especulativo e científico que simultaneamente satisfizesse "o melhor da inspiração digamos heraclitiana de um Bergson e as mais altas exigências de visão matemática do real de um Louis de Broglie." ${ }^{50}$ A ritmanálise já nasce dialética em sua origem, ao tentar abarcar

\footnotetext{
${ }^{50}$ Louis de Broglie foi um físico francês, condecorado com o prêmio Nobel de Física em 1929. No início do século XX ele desenvolveu a teoria da dualidade onda-corpúsculo da matéria, baseada na teoria dos quanta proposta por Max Planck e
} 
inspirações opostas. No entanto, repercutindo o pensamento de Heráclito, essa dialética busca a harmonia. Para Lúcio dos Santos é o ritmo que confere harmonia aos contrários, constituindo a própria energia de existência e princípio unificador da física, da biologia e da psicologia (CUNHA, 2012).

Ao discorrer sobre a ontologia do ritmo, a ritmanálise acaba por abordar a questão do tempo. Nesse contexto, o tempo só pode ser entendido a partir de uma pluralidade de tempos concretos e de uma vibração multiforme, expandindo os horizontes das passagens, em que a vida e o pensamento se tornem rítmicos. Superando a noção de repetição, a ritmanálise se aproxima muito mais de uma noção autêntica de ritmo, que implica uma constante renovação (Ibidem) - ideia que podemos ligar ao conceito nietzschiano de eterno retorno.

Maffesoli aponta como, desde a Grécia antiga, a noção de ritmo está ligada tanto ao estático quanto ao dinâmico, por meio do termo éon e, trazendo uma citação de Werner Jeager, esclarece: “o ritmo é aquilo que impõe vínculo aos movimentos, é aquele que contém o fluxo das coisas." (1998:60). O autor continua seu pensamento ao dizer que o fluxo não seria uma “desordem sem horizonte, mas um 'ponto de amarração' que se dinamiza." Ritmo, portanto, também é fluxo, ao permitir as passagens entre tempos superpostos, que abrangem tanto o repouso quanto o movimento, em constante oscilação.

Merleau-Ponty também acredita que a síntese do tempo é uma síntese de transição, e não haveria outra maneira de efetuá-la senão viver a transição em si (2011:567). Lúcio dos Santos, como acabamos de ver, proporia que essa transição fosse vivenciada por intermédio dos ritmos. Os ritmos, por sua vez, ao se alternarem, tornam perceptível a hesitação, que sustenta os pontos opostos desse movimento: “os contrários casam-se, depois separam-se, para novamente casar: valsa melancólica e lânguida vertigem." (CUNHA, 2012).

A ritmanálise se mostra como uma contínua possibilidade de um devir indefinido, que assume a hesitação ou a ruptura — ou, ainda, para retomarmos o pensamento heraclitiano, o contrário - por meio da oscilação própria a seu funcionamento. Essa é a ideia central que chama atenção de Bachelard na ritmanálise e que ele irá usar em seu livro La dialetique de la durée (1963) para se contrapor à tese bergsoniana da continuidade do tempo. Segundo Bachelard, Bergson enxerga na dialética um abrandamento da intuição que ele, por sua vez, acredita ser necessário para sua própria renovação. Em ambos, percebemos uma ligação do pensamento à noção de movimento bem como à valorização da questão da intuição, apesar de

Albert Einstein, abrindo caminho para uma nova área da física, a mecânica ondulatória — uma das principais bases da mecânica quântica. 
seus métodos divergirem. Destacamos aqui o fato de que, apesar de suas discordâncias, os dois podem ser considerados pensadores do fluxo.

Para Bachelard, dizer que uma ação dura de forma constante, pura e simplesmente, é se recusar a descrevê-la em detalhes. Ele contrapõe a esse pensamento, a necessidade do ritmo entre o sim e não; da vida incerta, efêmera, recusada e retomada, em que, em meio às passagens, se encontra, espalhada pelo tempo, a dialética do ser e do nada (1963:35). Dessa forma, "damos sentido pleno, por vezes ontológico e temporal, à formula bergsoniana: o tempo é hesitação." (Ibidem:35). Para Bachelard os tempos decisivos do tempo são suas descontinuidades e, dessa forma, ele propõe seu bergsonismo descontinuado (1963:19).

Concordamos com Bachelard sobre a necessidade da hesitação na constituição de um ritmo e na percepção do fluxo harmônico a partir de um ponto de vista interno ao próprio fluxo, daí nossa escolha, desde o começo, em tomar Heráclito como guia na compreensão desta noção. Encontramos aí uma possibilidade de observação pela intuição como propomos no início desta pesquisa. Buscando entender essa descontinuidade (ou hesitação) enquanto método, podemos relacioná-la à epoché fenomenológica de Husserl.

Segundo Husserl, essa dinâmica consiste em "colocar o mundo entre parênteses" (2008:80), ou colocar-se num estado de suspensão que possibilite a análise do mundo, levando em conta que nós também fazemos parte dele. Dessa forma, o filósofo privilegia o estímulo externo que nos atinge mediante a percepção e gera uma experiência sensorial pessoal, o que reforça ainda mais a fusão do sujeito e objeto em seu pensamento, buscando manter uma harmonia entre opostos que se torna possível justamente pelo intervalo. Heidegger irá interpretar essa mesma dinâmica por meio do conceito de "mundividência", no texto O tempo da imagem no mundo, publicado em 1938.

Retomando o pensamento da ritmanálise podemos dizer que ele se interessa pelo jogo entre imobilidade e movimento. A ritmanálise procura tornar possível a viagem imóvel por meio da suspensão. Essa seria uma maneira de constituir uma metodologia do fluxo que, ao priorizar a percepção e a experiência do sujeito, pode se conceber como uma estética do fluxo — ou um método estético do fluxo — , em que o movimento se encontra na estabilidade assim como a estabilidade no movimento, de forma a atingir uma harmonia.

Nesse sentido, trazemos à observação a obra Experiência de Cinema (2004) ${ }^{51}$ de Rosângela Rennó ${ }^{52}$, que nos faz vivenciar a experiência da hesitação, ou da descontinuidade.

\footnotetext{
${ }^{51}$ Disponível em: < http://vimeo.com/40170481> Acessado em 31/01/2014. Vídeo em DVD em anexo: pasta‘Capitulo_03’ $>$ 03.ExperienciaCinema.mp4

${ }^{52}$ Rosângela Rennó $(1962-)$. Site da artista: < www.rosangelarenno.com.br >
} 
Para tanto, uma parte fundamental do seu funcionamento está baseada no ritmo. A videoinstalação é constituída por uma projeção intermitente de imagens fotográficas sobre uma tela volátil - uma cortina de fumaça que permanece no espaço por apenas onze segundos. $\mathrm{O}$ hiato entre uma projeção e outra dura trinta segundos. Fumaça e imagem surgem e desaparecem simultaneamente, dando a sensação de que a imagem é tão efêmera e impalpável quando o vapor d'água que lhe serve de suporte. A artista busca questionar a noção de "espelho do real" que se atribui à fotografia - principalmente à fotografia documental. Por isso escolheu imagens que se referem aos temas clássicos da fotografia documental, tais como o Crime, a Guerra, a Família e o Amor, dando origem a quatro "filmes" que se alternam durante as projeções: "filme policial”, "filme de guerra", "filme de família"e "fillme de amor".

O intervalo que existe entre a projeção de uma imagem e outra é maior que o tempo de visualização de uma imagem em si, o que cria uma expectativa e, ao mesmo tempo, somandose à característica fluida do suporte gasoso, gera um questionamento sobre a materialidade da imagem anterior: eu realmente a vi? Mas, o que vi, realmente? As imagens não são nítidas, pertencem ao reino intermediário em que Warburg diz habitarem as imagens fantasma oscilam no tempo entre uma projeção e outra e também na própria instabilidade do meio vaporoso. Fugazes, elas apenas dão um vislumbre da suposta "realidade documental" que carregam. Imagens em bruma que se confundem com a dimensão do sonho - ou do devaneio, já que estamos despertos.

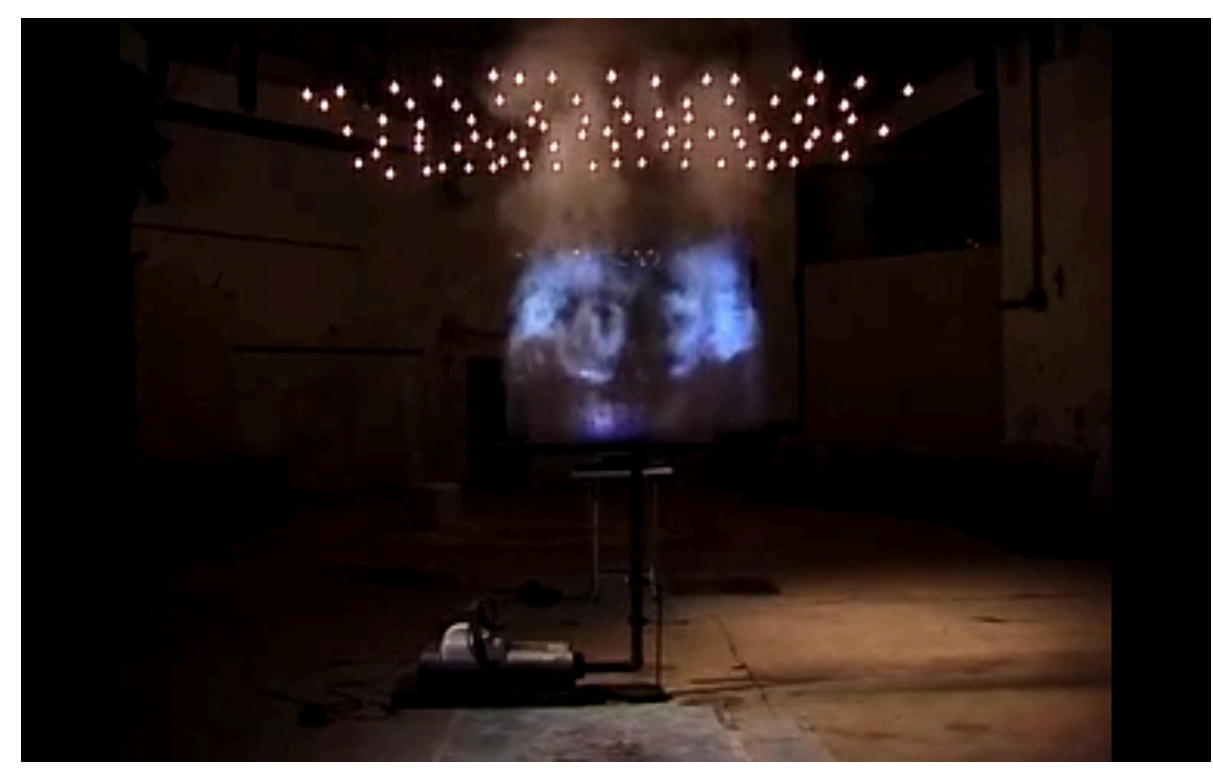

Figura 6: Vista geral da instalação Experiência de Cinema (2004), de Rosângela Rennó 


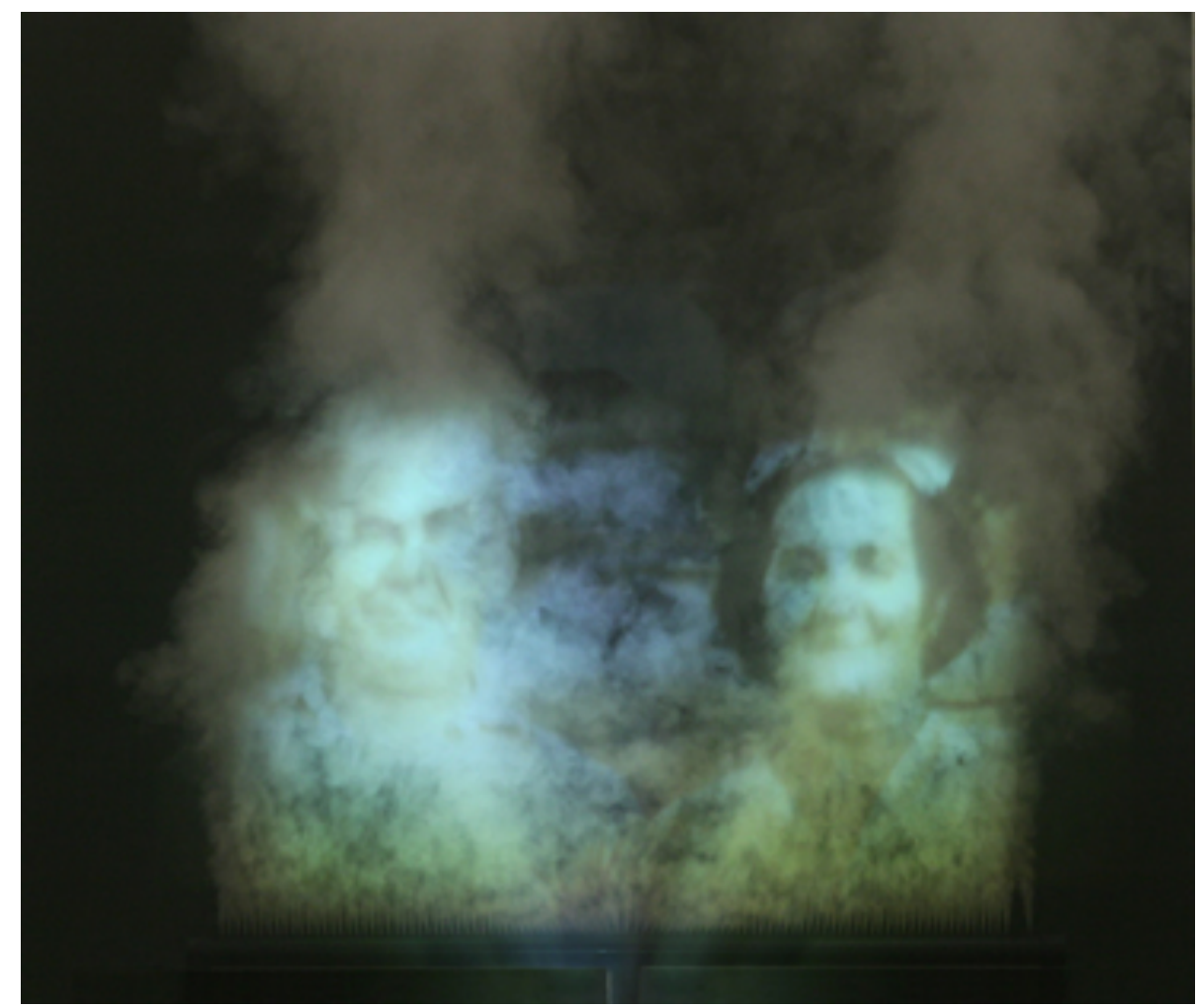

Figura 7: Detalhe das imagens fantasmagóricas nas projeções da obra Experiência de Cinema (2004)

A oscilação dessas imagens de sonho, que encontra seu fundamento na hesitação, permite, segundo Bachelard, estabelecer uma ligação entre a percepção do tempo vivido e do tempo pensado, naturalmente não sincronizados: "Sonhar é desacoplar os tempos superpostos." (1963:96). São imagens que se caracterizam também por seu hibridismo, não apenas devido à pluralidade temporal, mas também de forma, de material, de linguagem, entre outros. Imagens que se engendram mediante intervalos de passagem entre múltiplos pontos e só assim podem ser objeto de um devir: "Só uma pluralidade pode durar, pode evoluir, pode devir. E o devir de uma pluralidade é polimorfo, como o devir de uma melodia é, a despeito de todas as simplificações, polifônica." (BACHELARD, 1963:122).

Percebemos aí, a importância do hibridismo na oscilação e no devir, que se fazem perceber mediante uma dinâmica rítmica. No entanto, apesar da polimorfia, ou polifonia, dependendo da situação, a pluralidade em si, por mais múltipla que seja, é regida, no fundo, por um único ritmo. Segundo Bachelard, o verdadeiro ritmo poético é feito do grupamento de tonalidades: "Existe apenas um ritmo realmente independente e que comanda todos os outros. Como ritmos secundários, quer dizer, absolutamente comandados pela rítmica tônica, temos, de início, os timbres, em seguida, as durações.” (1963: 124).

Ora, ao falar sobre ritmo, não há como desvincular a relação com a música.. Não é recente o estabelecimento dessa ligação. Muito antes da possibilidade das plataformas 
multimídia, facilitadas pela tecnologia digital e encontradas nas obras de artemídia, já podemos citar estudos, peças musicais e demais tipos de experimentação em várias áreas das artes entre imagem e música.

Kandinsky ${ }^{53}$, pintor e professor da escola Bauhaus, estudou a relação entre cores, formas e música, assim como Paul Klee (1879 - 1940), outro conhecido pintor e professor da mesma escola. Na música, podemos citar o exemplo de Modest Mussorgsky (1839 - 1881), compositor russo que criou uma peça composta de dez músicas, chamada Quadros de uma Exposição (1874), inspirada nos quadros da exposição de um amigo, arquiteto e pintor, Viktor Hartmann (1834 - 1873), que havia morrido há pouco tempo. Claude Debussy (1862 - 1918) era um grande admirador do trabalho de Mussorgsky e, curiosamente, escreveu vários artigos comparando músicas às imagens, sob o peseudônimo de Monsieur Croche ${ }^{54}$. Em sua dissertação intitulada Imagens Musicais ou Músicas visuais $(2002)^{55}$, Filipe Salles cita como a gravura de Hokusai (1760 - 1849), A Grande Onda de Kanagawa (ca.1830) influenciou a criação da música La mer (1905), do compositor francês. Ele traz ainda um trecho de uma crítica em que Debussy discorre sobre a obra de Bach (1685 - 1750):

Na música de Bach, não é o caráter da melodia o que comove, é a sua curva $^{56}$; o mais das vezes, até, é o movimento paralelo de várias linhas cujo encontro, seja fortuito, seja unânime, solicita a emoção. Nessa concepção ornamental, a música adquire a segurança de um mecanismo de impressionar o público e faz surgirem imagens. (DEBUSSY,1989:36 apud SALLES, 2002)

Essa relação que se estabelece entre imagem e música provém de outra associação que podemos estabelecer entre o som e a luz, ambos de natureza vibratória e regidos não só pelo ritmo, mas por outras características que Filipe Salles (2002) chamará de características híbridas, tais como: a reflexão, a refração, a absorção, a transmissão e a difração. Ele ressalta que todas essas características são apenas observáveis em movimento, ou seja, em plena manifestação sonora ou luminosa, o que reforça a questão temporal e, consequentemente, o ritmo na ligação entre elas.

O cinema é uma das manifestações artísticas e culturais que mais se apropriou da relação híbrida entre imagem e som, buscando um ritmo entre elas a partir das escolhas de

\footnotetext{
${ }^{53}$ Para conhecer mais sobre os estudos de Kandinsky a respeito do assunto, sugerimos consultar os seguintes livros: Do espiritual na arte (1996) e Ponto e linha sobre plano (1997).

${ }^{54}$ DEBUSSY, Claude. Monsieur Croche, Trad. de Rachel Ramalhete. Rio de Janeiro: Nova Fronteira, 1989.

${ }^{55}$ Disponível em: http://www.mnemocine.com.br/filipe/tesemestrado/index.htm. Acessado em 13/01/2014

${ }^{56}$ Interessante relembrar que Bach é um compositor barroco e não por acaso Debussy faz referência à imagem da curva para descrever sua obra, pois a curva pode ser considerada um tipo de Dobra, tal como fala Deleuze em seus estudos sobre o Barroco.
} 
montagem. Seja a partir da estética da Escola Americana de Porter e Griffith ${ }^{57}$ ou da Escola Soviética com Vertov e Eisenstein ${ }^{58}$, ou ainda da contribuição francesa com Bazin ${ }^{59}$ e, mais tarde, Godard ${ }^{60}$, a linguagem cinematográfica se constrói tendo por base o ritmo na relação entre o visual e o sonoro. Aqui, retomamos com destaque o cinema abstrato de vanguarda, especificamente na Europa, em que podemos citar nomes de artistas conhecidos ligados principalmente à pintura e à fotografia, como Fernand Léger ${ }^{61}$, Marcel Duchamp ${ }^{62}$, os irmãos Bragaglia $^{63}$, László-Moholy-Nagy ${ }^{64}$, entre outros. No entanto, queremos fazer ainda um recorte mais específico, sobre os nomes de alguns artistas que se aprofundaram na abstração para experimentar com os elementos básicos do design, como a forma e a cor, aliados à música, buscando repercutir os estudos de Kandinsky (1866 - 1944) sobre uma música visual, ou música cromática, como é o caso de Walter Ruttmann (1887-1941) e Oskar Fischinger $(1900-1967)$.

Em seu primeiro filme, chamado Lischtspiel, Opus $I(1921)^{65}$, considerado um dos primeiros filmes abstratos da história do cinema, Walter Ruttmann procura explorar a ideia de ritmo e harmonia, criando uma dança entre os elementos visuais que acompanham a música composta por Max Butting especialmente para o filme. Ruttmann busca traduzir nas imagens em movimento as sensações despertadas pela música e consegue provocar no espectador, por

\footnotetext{
${ }^{57}$ A Escola Americana se inicia com a proposta de uma montagem fluida baseada na forma narrativa, tal como propõe o cineasta Edwin S. Porter a partir do filme Life of an American fireman (1902). David W. Griffth dá continuidade à montagem narrativa numa concepção mais moderna, conferindo ao filme maior "impacto dramático, recorrendo à justaposição de planos." (DANCYGER;2006 apud CANELAS;2010).

58 A Escola Soviética de montagem, cujos cineastas de maior destaque são Sergei Einsenstein e Dziga Vertov, dialoga com a proposta de Griffth e acrescenta algumas ideias tais como a de que o sentido de um plano depende de sua relação com os planos restantes (conforme propõe o cineasta Lev Kulechov); ou a da montagem construtiva (Pudovkin), ou ainda das montagens métrica, rítmica, tonal, harmônica e intelectual (Einsenstein), bem como a ideia da perspectiva realista do cineolho (Vertov) (CANELAS;2010).

${ }^{59}$ André Bazin (1918 - 1958), francês, crítico e teórico do cinema, buscava uma "realidade objetiva", desafiando a tradição formativa da escola soviética. Em seus filmes propunha o uso da profundidade de campo, de planos gerais e do planosequência. Suas ideias encontraram eco no surgimento do neorrealismo italiano (ANDREW; 1989)

${ }^{60}$ Jean-Luc Godard $(1930$ - ) é um dos principais cineastas da Nouvelle Vague francesa cujos filmes, em termos de montagem, são reconhecidos, em diferentes fases de sua carreira, ora pelos demorados planos-sequências, ora pela descontinuidade, ou pela improvisação ou ainda pela tentativa de atribuir à imagem significados contraditórios. O cineasta transita da fase "política" à fase "vídeo" num duplo movimento de passagem de imagens: de um lado, da pintura rumo à colagem; de outro, do vídeo rumo ao cinema."(DUBOIS;2004: 251).

${ }^{61}$ Da obra de Fernand Léger (1881 - 1955) conhece-se principalmente a relação com a pintura cubista. No entanto, o artista francês também se voltou à escultura e ao cinema.

${ }^{62}$ Marcel Duchamp $(1887$ - 1968) realizou obras de pintura, escultura, cinema, fotografia e também voltou-se à poesia. Ficou mais conhecido por conceber os ready mades (uso de objetos industrializados e do cotidiano no âmbito das artes) e transitou entre os movimentos cubista, dadaísta e surrealista.

${ }^{63}$ Os irmãos Arturo Bragaglia (1892-1962) e Carlo Ludovico Bragaglia (1894-1998) criaram o fotodinamismo na tentativa de capturar movimento dinâmico por meio da fotografia. Sua proposta dialogava com o movimento Futurista.

${ }^{64}$ László-Moholy-Nagy (1895 - 1946) foi professor da Bauhaus e se voltou à pintura e à fotografia, principalmente com a técnica do fotograma. Também realizou experimentos em cinema.

${ }^{65}$ Disponível em: < http://www.youtube.com/watch?v=k9vSRPN4jDk > Acessado em 13/02/2014. Vídeo em DVD em anexo: pasta'Capitulo_03' >> 04.Lischtspiel_Opus I.mp4
} 
meio da sinestesia, a percepção de uma espécie de leveza, como se nós também acompanhássemos os movimentos das formas e cores e nos deixássemos levar pela música.

Por mais que a música se torne agressiva e forte em alguns momentos — nos quais ele realiza a animação por meio de uma sequência de triângulos pontiagudos que penetram e deixam a tela rapidamente, de forma brusca —, ainda assim nos sentimos parte do movimento, graças à harmônica associação entre som e imagem por meio do ritmo. Nesse filme, apesar do grande uso das formas geométricas puras, como o círculo, o quadrado e o triângulo, em alguns momentos encontramos formas orgânicas e fluidas, que acompanham os trechos mais suaves da música. Essas formas naturais que se movem rapidamente se parecem a velozes peixes que por vezes interagem entre si, por vezes passam, por vezes não. Faço uma associação visual quase imediata com os pássaros da obra Infinity III (2012-2013), sobre a qual falamos anteriormente. Percepções que se assemelham. 


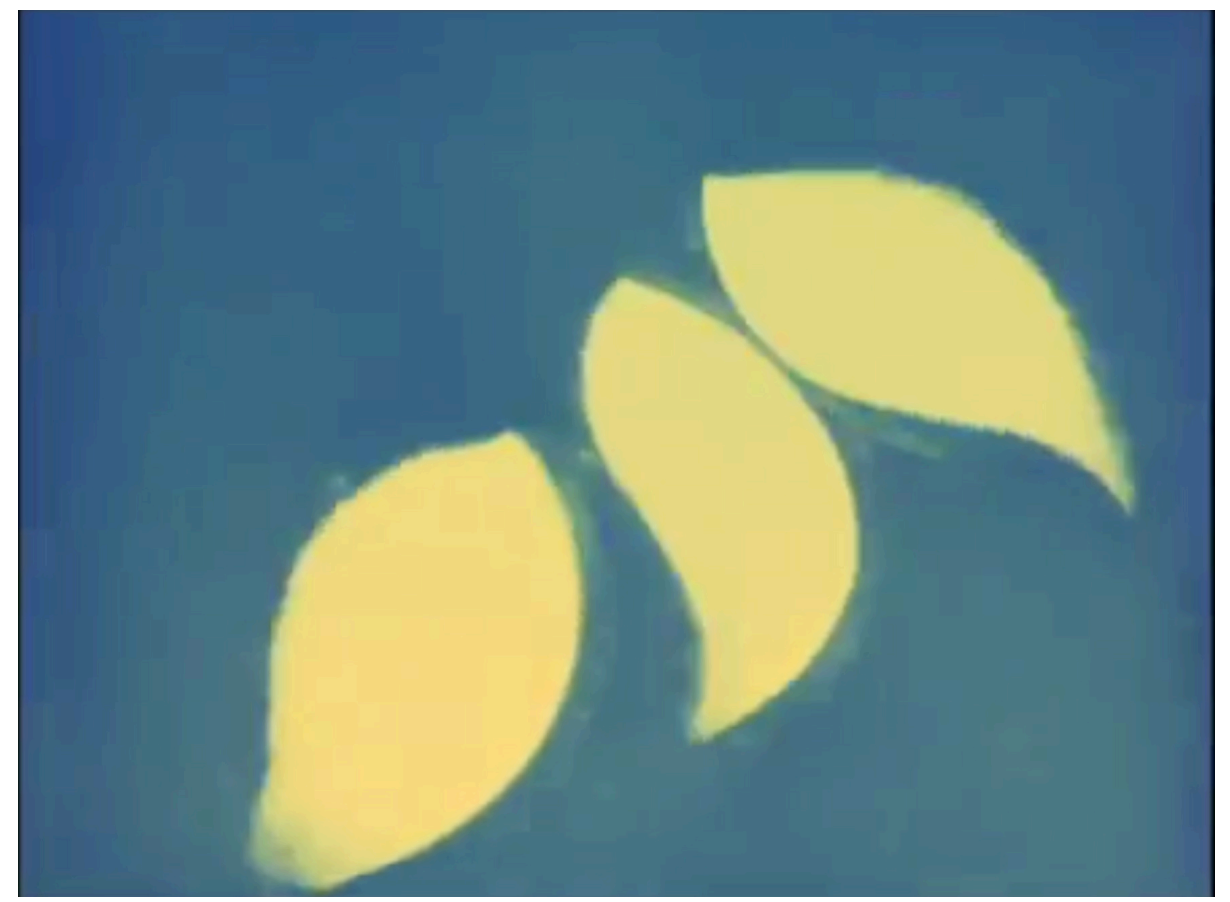

Figura 8: Frame do filme Lischtspiel, Opus I (1921), de Walter Ruttmann

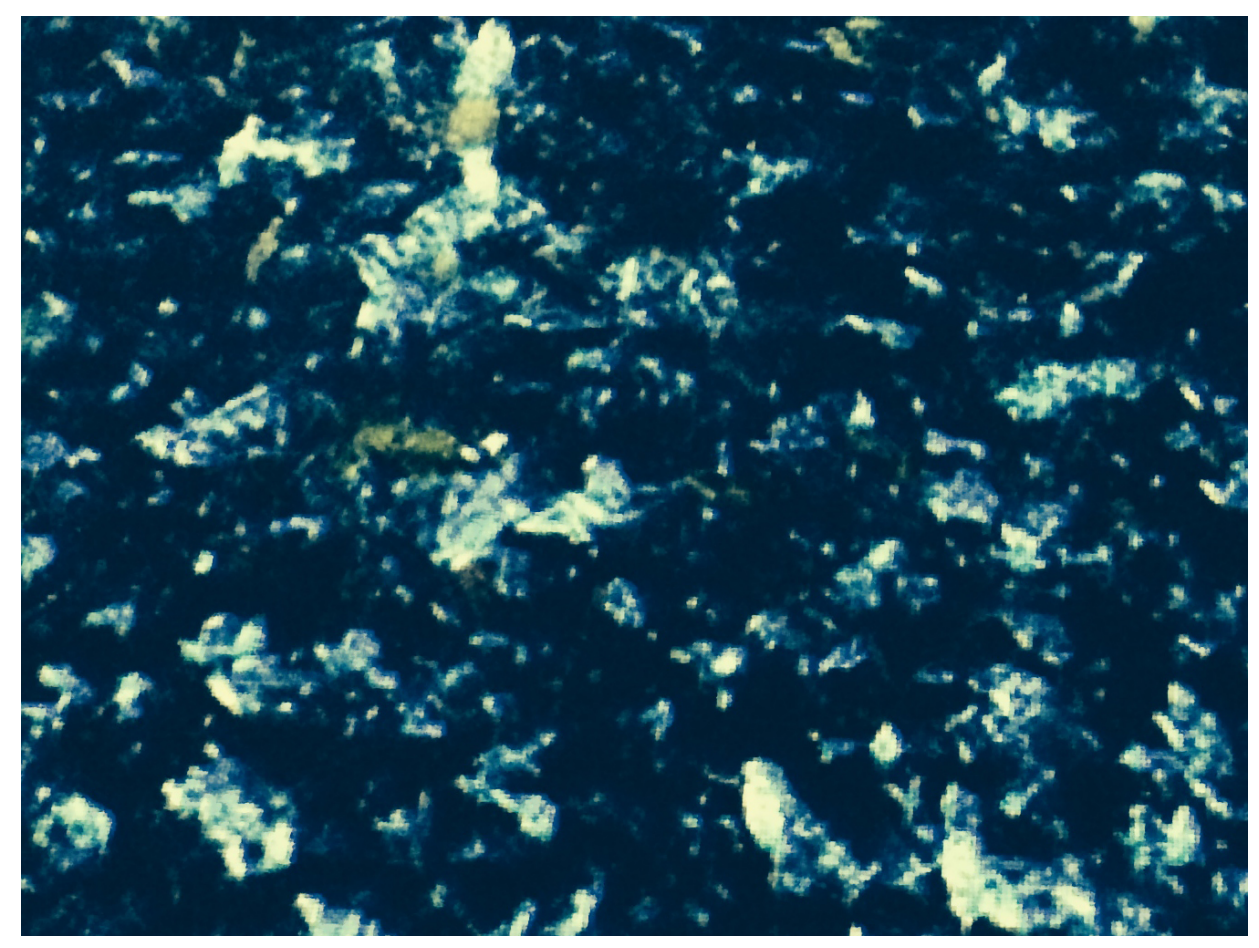

Figura 9: Detalhe da imagem dos pássaros digitais na obra Infinity III (2012 - 2013) 
Também o filme de Oskar Fischinger, An Optical Poem (1938) ${ }^{66}$, me faz estabelecer uma relação visual com outra obra anteriormente analisada, Exploded View (Commuters) (2011), de Jim Campbell. O cineasta se utiliza de formas geométricas básicas, principalmente círculos, para tentar externar as imagens mentais provocadas pela música Rapsódia Húngara $n^{o} 2$ (1847), de Franz Litsz (1811 - 1866) - como afirma o texto no início do filme. Em vários trechos em que o ritmo da música acelera, revelando sua influência da música folclórica húngara, Fischinger se utiliza de formas circulares de colorações mais claras que dançam e oscilam sobre um fundo mais escuro, assim como a visualização da instalação de luzes suspensas na obra Exploded View (Commuters).

\footnotetext{
${ }^{66}$ Disponível em: < http://www.youtube.com/watch?v=they7m6YePo> Acessado em 13/02/2014. Vídeo em DVD em anexo: pasta 'Capitulo_03' >> 05.Optical_Poem.mp4
} 


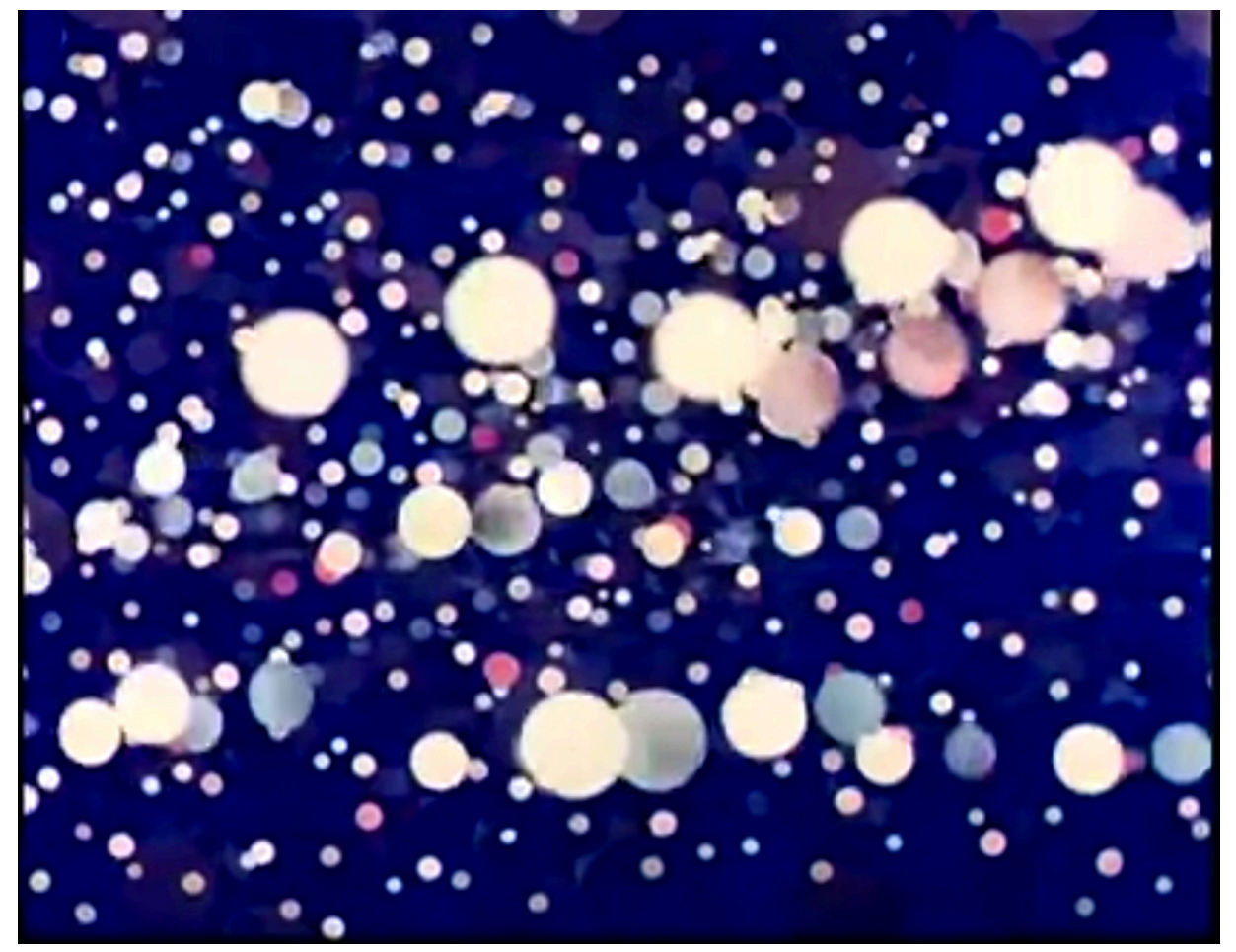

Figura 10: Frame do filme An Optical Poem (1938), de Oskar Fischinger

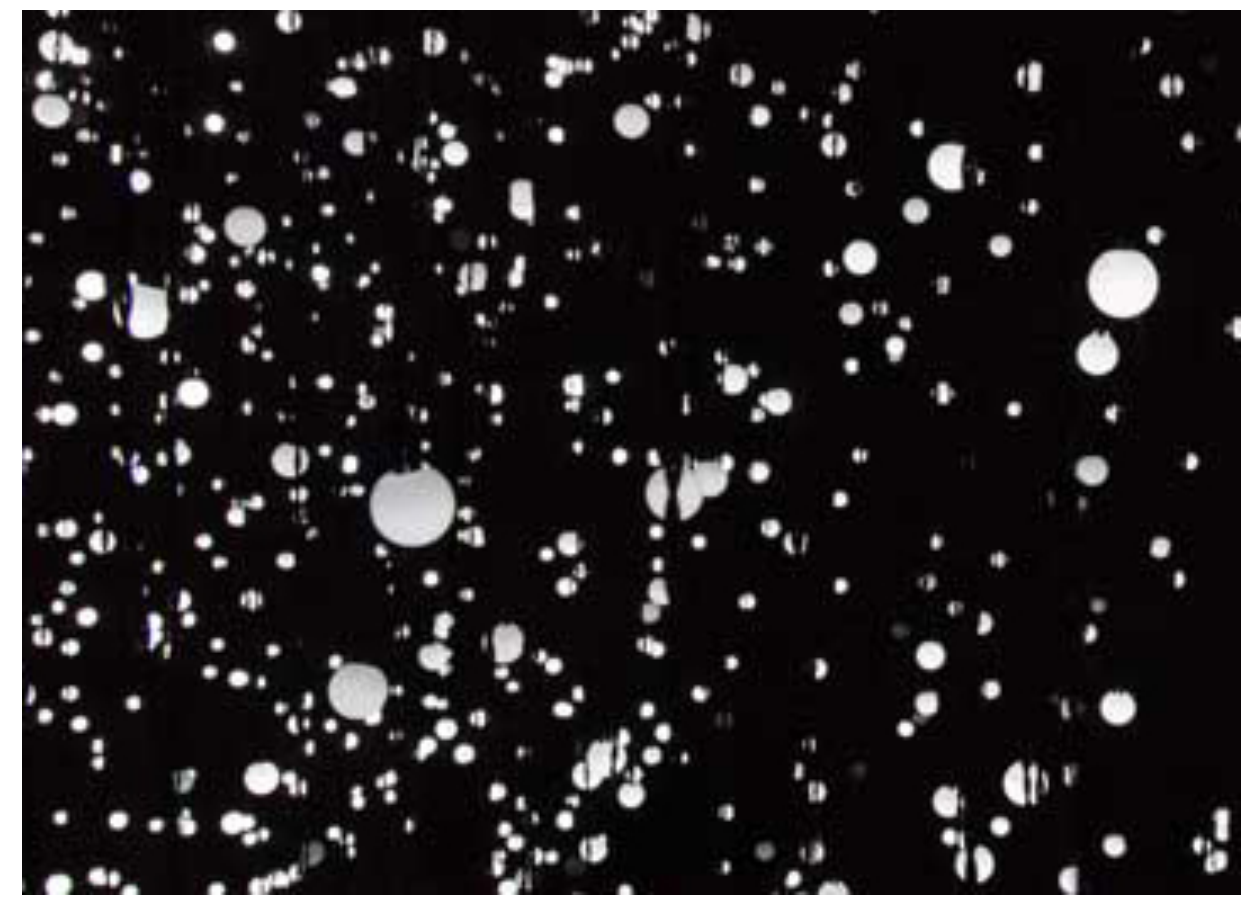

Figura 11: Ponto de vista da obra Exploded View (Commuters) (2011) que se assemelha ao frame do filme de Oskar Fischinger 
Oskar Fischinger foi influenciado pela pintura abstrada de Kandinsky e Malevich ${ }^{67}$ (1978 - 1935). Segundo Patrícia Branco ${ }^{68}$, "naquilo que nos faz lembrar Malevich, em Fischinger, a tentativa de criar uma linguagem não-objetiva, abstrata e, portanto, universal, alia-se à crença de que o cosmos será constituído por luz, espaço e ritmo". Quanto à relação com Kandinsky, o cineasta, assim como o pintor, procurava, nas formas abstratas, aceder a um domínio suprasensorial. Kandinsky fala sobre a forma abstrata como "expressão exterior do conteúdo interior. [...] Assim, o espírito de cada artista se reflete na forma."(1996:142-143). Para ele a noção de harmonia e equilíbrio encontra-se não nos objetos, mas dentro do próprio artista. $\mathrm{O}$ pintor e também professor da Bauhaus ainda acreditava que a arte abstrata é significante no mais alto nível; que ela constitui uma linguagem que pode falar mais alto que a figuração da natureza (1996:224).

Hoje, um ponto às vezes diz mais na pintura do que uma figura humana. Uma vertical associada a uma horizontal produz um som quase dramático. $\mathrm{O}$ contato do ângulo agudo de um triângulo com um círculo não tem efeito menor que o do dedo de Deus com o dedo de Adão em Michelangelo. $(1996: 228)$

Ainda sobre a questão da forma abstrata como linguagem poética, Flusser, no livro Lingua e Realidade (2007), diz que a língua "abrange todas as formas de pensamento e todas as atividades do intelecto. [...] Essas extensões da língua chamei de música e plástica e, em seu conjunto, formam a totalidade da língua." (2007:181). O autor aproxima a dimensão plástica da língua à poesia na medida em que as formas "são arrancadas do nada." (2007:176). Quanto mais o pintor-poeta tenta superar-se a si mesmo, mais ele apela ao nada, chegando mais próximo ao silêncio autêntico. Nessa dimensão poético-plástica em que as formas são arrancadas do "nada", encontramos, segundo o autor, uma pintura abstrata em que o que resta são composições estruturais de linhas, planos, corpos e cores.

Partindo de uma visão ligada inicialmente à música, podemos citar o exemplo do compositor russo Alexander Scriabin $(1871$ - 1915), cujo interesse em aliar música à cor o levou a compor peças para serem executadas em conjunto com uma performance luminosa na sala de concertos, utilizando um órgão de cor — chamado luce, em italiano - , como é o caso de Poema do Extase (1908) e Prometeu: Poema de Fogo (1910). Seu intuito era sucitar no espectador uma espécie de êxtase místico que provocasse uma transcendência espiritual. Em 2010 uma doutoranda de Yale, Anna Gawboy, estudiosa do compositor, montou uma equipe

\footnotetext{
${ }^{67}$ Kazimir Malevich foi um pintor abstrato soviético. Fez parte da vanguarda russa e mentor do movimento suprematista.

${ }^{68}$ BRANCO, Patrícia. Cinema Abstracto: Da vanguarda europeia às primeiras manipulações digitais da imagem. Disponível em: < http://www.bocc.ubi.pt/pag/bocc-cinema-patricia.pdf > . Acessado em 13/02/2014
} 
de músicos e designers de luz para reproduzir, pela primeira vez, a partir das anotações originais de Scriabin, a performance da peça Prometeu: Poema de Fogo, que até então não se fazia possível por limitações tecnológicas ${ }^{69}$.

A performance imaginária de Alexander Scriabin é, em sua concepção, multimídia, mesmo que essa designação não lhe fosse atribuída no início do século $\mathrm{XX}$, por ainda não existirem plataformas digitais, o que não anula sua característica híbrida e poética, cuja construção se dá conforme um ritmo entre luzes coloridas e música. A capacidade de imaginar tal relação e, por meio da força das imagens mentais chegar a experimentar a sensação proveniente delas, não é só admirável como possível. Basta nos lembrarmos da cena do filme E la nave va (1983), de Federico Fellini (1920 - 1993), em que a personagem cega, interpretada pela dançarina Pina Bausch (1940 -2009), associa um tom de azul a cada nota musical da valsa Danúbio Azul, durante um jantar: "A música a faz ver um arco-íris de cores", diz o irmão da personagem. Os demais convidados discutem sobre a veracidade de tal capacidade, questionando a possibilidade de comprovação científica do fenômeno, pois qualquer um poderia dizer ver qualquer cor. De repente a discussão é interrompida por outra comensal que diz: "É claro que nem todos podem ter uma alma tão sensível assim."

Como afirmamos anteriormente, Bachelard acredita que o verdadeiro ritmo poético é feito de um grupamento de tonalidades - assim como encontramos em todos os exemplos acima, em tons provenientes tanto da música quanto da cor. No entanto, o filósofo ressalta que apesar do aspecto múltiplo — ou híbrido — existe apenas um ritmo que realmente comanda todos os outros. Assim, vemos que uma característica importante das obras de artemídia, justamente por se constituírem sobre uma plataforma multimídia, é o hibridismo, que permite a formação de um todo múltiplo permeado de passagens e possibilitando a oscilação atribuída a esse ritmo que governa os outros ritmos - e que aqui acreditamos ser uma manifestação do fluxo em si.

\subsection{Hibridismos: oscilações e percursos nos espaços de passagem}

Vimos que a própria ideia de ritmo só se faz perceptível numa multiplicidade que permita a existência de intervalos — ou passagens — estabelecendo uma relação entre partes que formam um todo em prol de uma harmonia conjunta. Podemos dizer que uma característica importante para que o próprio ritmo exista é a presença de uma pluralidade, que aqui vamos

\footnotetext{
${ }^{69}$ Disponível em: http://www.youtube.com/watch?v=V3B7uQ5K0IU > Acessado em 13/02/2014. Vídeo em DVD em anexo: pasta 'Capitulo_03' >> 06.Scriabin_Prometheus.mp4
} 
chamar de hibridismo, para efeito de uma compreensão maior acerca da relação entre diferentes linguagens multimídia que constituem as obras de artemídia.

O hibridismo, então, após nossa discussão acerca do ritmo, aparece como o segundo elemento constituinte de uma importante característica da estética do fluxo, que é a oscilação. Para compreender o hibridismo temos que nos posicionar no seio instável do movimento, próprio à sua dinâmica rizomática, que se sustenta no espaço entre linguagens, principalmente no cenário das mídias digitais. É nesse espaço que se abre a possibilidade para a participação do observador no caso de uma obra de artemídia, por exemplo. Raymond Bellour chama atenção para essa questão em seu livro L'Entre-images (1997) ao afirmar que não faz mais sentido pensar cada meio individualmente, mas sim nas relações que se estabelecem nessas passagens entre um e outro. É na passagem que podemos compreender melhor as tensões e ambiguidades que se dão entre o movimento e a imobilidade, antes restritos às manifestações puristas de um determinado tipo de linguagem, respectivamente. Segundo Arlindo Machado, o núcleo duro de um meio ou linguagem, que por si só já é expandido, acaba ecoando em outro, o que acaba por nos remeter à questão da sinestesia: "a música é visual, a escultura é líquida ou gasosa, o vídeo é processual, a literatura é hipermídia, o teatro é virtual, o cinema é eletrônico, a televisão é digital.” (2010:72).

Essa escritura múltipla, facilitada pela tecnologia digital, compõe, segundo Machado, um tecido de rara complexidade o que, sem dúvida, pode significar a possibilidade de inovação mas também pode resultar no que ele chama de estética da saturação. Concordamos com o autor nesse ponto e, por isso, acreditamos ser importante, para o estabelecimento de uma estética do fluxo, pensar o hibridismo associado ao ritmo, como fizemos na observação das obras de artemídia apresentadas anteriormente.

Esse é um dos mais importantes diferenciais que acreditamos ser próprio à estética do fluxo, pois uma primeira leitura sobre nossa proposta poderia levar a relacioná-la apenas aos conceitos já existentes a respeito de uma estética pós-moderna, ou de uma estética do pastiche e da simulação, fazendo referência a Frederic Jameson (2006) e Jean Baudrillard (1991), respectivamente, ou ainda uma estética da hipervenção como propõe Denize Araújo (2007). Todas essas abordagens dão grande destaque ao aspecto intertextual, móvel, cambiante e complexo das relações contemporâneas nos mais diversos âmbitos o que é, sem dúvida, pertinente, devido ao seu caráter atual e pujante, principalmente em manifestações artísticas, culturais e midiáticas. No entanto, ao olharmos para esse cenário a partir de um ponto de vista flutuante e intuitivo, como propomos desde o início de nossa metodologia, procuramos nos inserir no movimento e compreender o núcleo das passagens instáveis e efêmeras que se 
estabelecem nessas relações. Voltamos a destacar a importância da oscilação rítmica para tornar esse processo possível. Por se tratar de uma estrutura rizomática, a ligação entre os platôs - para usar a terminologia de Deleuze e Guattari — é que torna possível a geração de diversos significados resultantes dessas relações. E se o fluxo implica em harmonia, como já afirmava Heráclito, é mediante o ritmo que conseguimos realizar uma composição equilibrada nessas inúmeras possíveis passagens de um rizoma híbrido. A vocação desse tipo de relação é servir como mediadora entre elementos díspares ou dicotômicos, fortalecendo seu pertencimento a uma prática tipicamente comunicacional.

Além disso, outro diferencial que encontramos em nossa proposta diz respeito a uma relação que extrapola a dimensão da intertextualidade. As interfaces digitais estão cada vez mais se integrando aos movimentos do corpo, buscando serem mais intuitivas e interativas. Para além de uma questão de linguagem múltipla, o que se busca são interfaces híbridas em que o corpo possa fazer parte delas. Podemos dizer que esse tipo de interface estaria uma etapa adiante da ubiquidade sobre a qual tanto se fala hoje em dia, ligada à mobilidade dos smartphones, tablets e demais tipos de dispositivos computacionais portáteis que nos permitem estar conectados à internet em todos os lugares, o tempo todo. O caráter onipresente continuará sendo essencial, no entanto, o que se intensificará será a interação, que se manterá constante e imperceptível, como se fosse parte do próprio corpo do usuário.

As interfaces de hoje ainda estabelecem um distanciamento entre o corpo e o dispositivo. É claro que não as manipulamos mais com um teclado ou mouse, ou seja, com a tecnologia do touchscreen podemos tocá-las e utilizá-las de forma mais intuitiva, mas ainda olhamos para uma tela, que não faz parte de nós mesmos e vice-versa. O próximo passo será usar o próprio corpo como interface, “desconectado de suas próteses tecnológicas, corpóreas ou maquínicas. O sujeito é aqui, ele próprio, uma interface entre o cérebro e o mundo." (BENTES in BRUNO et al., 2006:93), assim como propõe o wearable computing ${ }^{70}$, por exemplo. Professor do departamento de engenharia elétrica computacional da Universidade de Toronto, Steve Mann, é um estudioso e entusiasta do tema e define esse tipo de computação como tendo por objetivo contextualizar o computador de forma que humano e máquina estejam inextricavelmente entrelaçados, buscando uma inteligência humanística onde a interação seja constante (MANN, 2013), ou seja, em que não precisemos ligar ou desligar um dispositivo, pois estaremos imperceptivelmente e constantemente conectados ou em fusão com ele.

\footnotetext{
${ }^{70} \mathrm{~A}$ tradução para o português seria computação vestivel
} 
A realidade aumentada constitui uma tentativa de compor ambientes em que essa separação não se faça evidente, ela sustenta o intervalo entre o real e o virtual com a fusão de imagens dessas duas naturezas, criando uma realidade mista. Recentemente, o Google lançou um produto inovador, o google glasses ${ }^{71}$ que busca, por meio de um aparelho que simula uns óculos, com uma pequena tela que permanece na frente do olho, integrar a imagem que vemos àquela projetada, quase sem que haja disntinção entre as duas realidades, que se sobrepõem e se completam nessa realidade mista (voltaremos a nos referir a esse dispositivo no quarto capítulo, ao aproximarmos a estética do fluxo à Comunicação). Um experimento do MIT (Massachussetts Institute of Technology) apresentado no encontro TED Talks ${ }^{72}$ de 2009, chamado Sixth Sense, já desenvolveu um protótipo de dispositivo em que um projetor pode transformar qualquer superfície em interface de interação. Com o desenrolar dos estudos nesse sentido, em breve teremos uma apropriação cada vez maior do espaço, fazendo com que habitemos espaços híbridos entre o real e o virtual, em que nosso corpo não apenas manipule interfaces mas se transforme numa interface também.

Certamente esses objetos constituem um vasto e singular campo de estudo, no entanto, usamos esses exemplos apenas para fazer um contraponto ao nosso objeto de estudo principal, as obras de artemídia. A proposta de grande parte das obras que trazemos à análise aqui busca criar a sensação de imersão a partir de imagens impalpáveis, muitas vezes provenientes de projeções luminosas que promovem a integração entre ambiente, corpo e imagem, trazendo o observador à participação e fazendo-o fundir-se à obra. Ao olharmos para essa relação, hoje, podemos vislumbrar como tais situações transformarão a ontologia da imagem e do ser frente às imagens, mediante as interfaces que virão.

O hibridismo do qual tratamos aqui, aborda, sim, o aspecto intertextual mas, para além disso, ao consolidar seu aspecto fluido, ele busca alargar essa discussão ao pensar na questão corporal e, consequentemente, espacial da imagem que é uma imagem-relação. Lembremonos de que na metáfora do rio, em Heráclito, a presença do corpo e sua imersão é parte essencial para compreensão do movimento, ou seja, do fluxo. Nessa forma que surge híbrida com a máquina percebemos, como propõe Suzete Venturelli (2011:151), a tentativa do sujeito de se misturar no campo puro da imagem, talvez pelo fato de que a imagem, sendo um vetor de união, possa projetar o sujeito muito além dele mesmo, numa busca por livrar-se do corpo, revelando o que David Le Bretron analisa como um medo da morte (2013:17).

\footnotetext{
${ }^{71}$ Disponível em: < http://www.youtube.com/watch?v=D7TB8b2t3QE >. Acessado em 17/02/2014. Vídeo em DVD em anexo: pasta'Capitulo_03'> 07.GoogleGlasses_Presentation.mp4

${ }_{72}$ Disponível em: < http://www.youtube.com/watch? $=$ nZ-VjUKAsao >. Acessado em 17/02/2014.Vídeo em anexo: pasta 'Capitulo_03 >> 08. SixthSense_Presentation.mp4
} 
Venturelli destaca ainda o fato de que essa busca, nas artes visuais, se tornou preponderante por meio da intensificação da participação na obra, que podemos perceber nas instalações, nas performances e nas poéticas colagísticas da pop-art e videoarte - todos estilos de arte híbrida e em diálogo com a vanguarda dadaísta. A performance artística, por exemplo, pode ser considerada um híbrido entre teatro, dança, cinema, vídeo e artes plásticas e tem suas primeiras manifestações ligadas aos happenings, verdadeiros rituais artísticos que eram muito comuns no movimento Fluxus ${ }^{73}$. George Maciunas (1931 - 1978) foi o mentor do movimento e se decidiu pelo nome após uma busca pela palavra "fluxo" no dicionário, selecionando todas as definições que tinham conotações de mudança, purificação, fluidez e fusão (HENDRICKS et al.;2002). Ele não acreditava na separação entre vida e arte, e procurava abolir com a arte dita erudita.

Um exemplo de performance híbrida é o trabalho da coreógrafa Sasha Waltz, que foi tema de exposição no ZKM (Zentrum für Kunst und Medientechnologie) em Karlshue, Alemanha, em 2013, visitada em dezembro do mesmo ano. A pergunta que nos fazemos incialmente especula qual seria o papel da obra de uma coreógrafa como destaque principal de um importante centro voltado à artemídia: Sasha Waltz. Installations, Objects, Performances. Ao adentrar a exibição, a primeira obra que encontramos, Nobody (2000), constituía, naquele espaço, uma videoinstalação com três telas de grande dimensão, em frente às quais podíamos nos sentar. As telas se assemelhavam a janelas onde víamos, em cada uma delas, uma imagem desfocada de uma mulher que ora se afastava, ora se aproximava, mostrando as mãos como se encostasse no vidro da suposta janela pelo lado de dentro, dando a impressão de querer fazer algum contato. A grande dimensão da tela reforçava a percepção de uma situação real, como se alguém estivesse aprisionada ali, pedindo para sair. $O$ desfoque, que não nos permitia definir bem a imagem da mulher, aumentava a sensação de distância entre ela e o observador, intensificando o desconforto da impotência de estar diante de uma pessoa que parecia pedir por nossa ajuda, mas não podíamos fazer nada, principalmente porque seu movimento a fazia se aproximar e se afastar constantemente, como se ela tivesse apenas algumas breves oportunidades de pedir socorro. A obra, no entanto, faz parte de uma performance em que as

\footnotetext{
${ }^{73}$ Fluxus foi um movimento artístico e cultural de arte multimídia de vanguarda iniciado na década de 1960 que trouxe a filosofia zen-budista para o happening e o entrecruzamento de linguagens para a arte. Seu mentor, George Maciunas, via o movimento como concreto, uma espécie de niilismo da arte (antiarte) que ele definia da seguinte maneira: "Antiarte é vida, é a natureza, é a verdadeira realidade - é o único e o todo. A chuva é antiarte, um espirro é antiarte.” (HENDRICKS et al.; 2002:14, grifo nosso). O objetivo era sujeitar todas "as artes do 'tempo' às artes do 'espaço', sem fronteiras: sistematicamente desvelar todo o contínuo espaço/temporal burguês existente por meios artísticos, trocando todos os seus estilos e suportes por uma nova forma de Arte Concreta governada por uma radical unidimensionalidade.”(Ibidem:52)
} 
telas apenas constituem parte de um grande cenário onde se desenrola um espetáculo de dança contemporânea, parte de uma trilogia que explora a temática do corpo ${ }^{74}$.

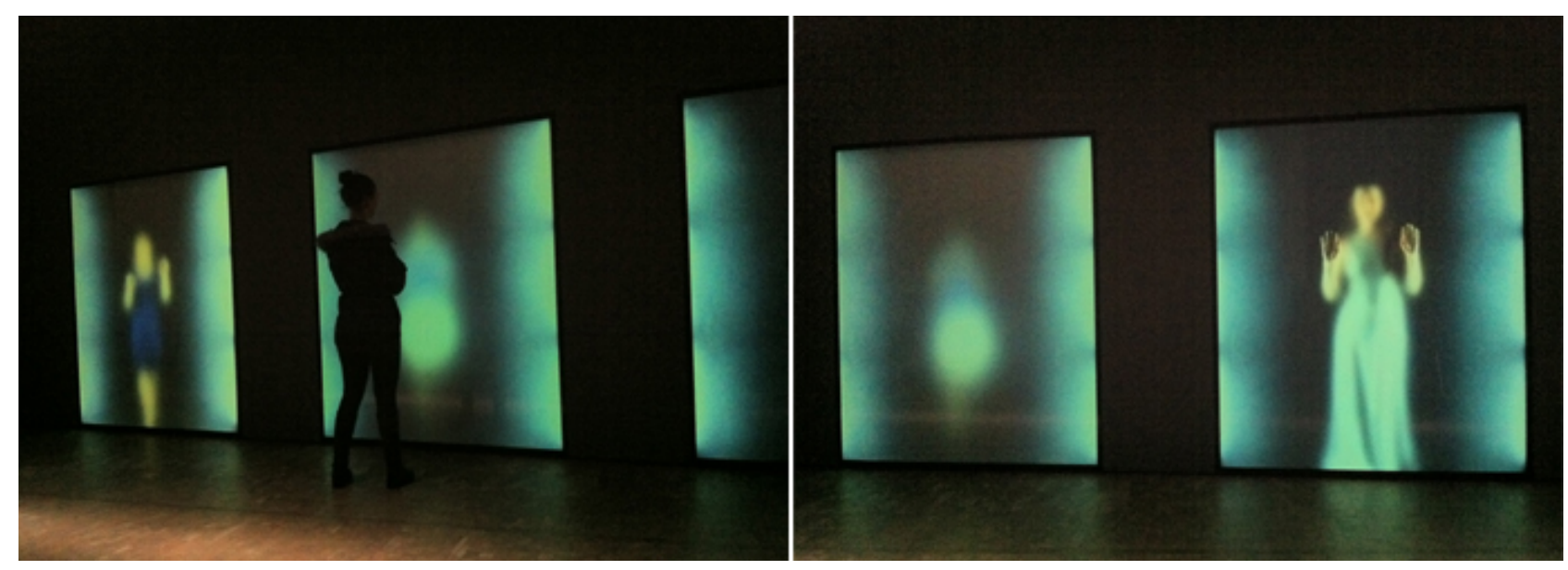

Figura 12: Nobody (2000)

A obra de Sasha Waltz ${ }^{75}$ é pensada para uma performance de palco mas também para o registro de vídeo, não um registro documental clássico, mas uma forma para dar continuidade à intencionalidade de sua obra-performance em videoinstalações, que se desenrolam em outro espaço, em outras mídias, mas dialogam com a proposta da performance. Esse diálogo constitui o ponto alto da obra da coreógrafa que passeia entre as mais variadas manifestações da arte, criando naturalmente híbridos em que a questão do corpo é problematizada constantemente, tanto no momento da performance quanto nas videoinstalações resultantes dela.

Dentre as várias videoinstalações, performances e objetos acompanhados de vídeo que constituíam a exposição, uma obra que chama atenção, em particular, é Dido \& Aeneas Waldbühne (2011). Um grande tanque de água ocupava um vão de pé-direito duplo do museu. Sozinho, poderíamos classificar o tanque num gênero de escultura. Porém, acompanhando o suposto objeto-escultura havia um vídeo, mostrando a performance de apresentação da ópera coreografada por Sasha Waltz. Dido e Eneias é uma ópera do compositor barroco inglês Hery Purcell (1659 - 1695), baseada na Eneida de Virgílio (70 a.C. - 19 a.C.) e encenada pela primeira vez em 1688, em Londres. A ópera, por si só, já se constitui numa arte híbrida entre literatura, música e teatro e, no caso de Sasha Waltz, percebemos ainda um diálgo evidente com a dança e também com a pintura.

\footnotetext{
${ }_{74}^{74}$ As duas outras performances da trilogia são Körper (2000) e $S$ (2000), ambas de Sasha Waltz.

${ }^{75}$ Sasha Waltz (1963 - ). Site da artista: www.sashawaltz.de
} 
O que mais chama atenção nas primeiras cenas da apresentação bem como nos registros fotográficos da performance e no vídeo é, sem dúvida, as cores e a luz do cenário. A coreógrafa começa o espetáculo com uma cena em que dançarinos desenvolvem um balé nesse tanque de água de grandes dimensões, onde os graciosos movimentos se tornam ainda mais leves e fluidos. A luz, que intensifica as cores, tem um tom dourado, criando áreas de luminosidade e outras de sombra, numa referência à luz dos quadros do holandês Vermeer ${ }^{76}$ $\left(1632\right.$ - 1675) e à técnica do chiaroscuro ${ }^{77}$, típica do barroco e da obra de pintores como Rembrandt (1606 - 1669) e Caravaggio (1571 - 1610), por exemplo. A releitura de Waltz da ópera de Purcell, ao ser apresentada no ZKM, resulta em um pensamento híbrido em que podemos envolver, portanto, múltiplas linguagens e estéticas artísticas que passam pela literatura, música, teatro, dança, pintura, escultura e vídeo.

\footnotetext{
${ }^{76}$ Johannes Vermeer foi um pintor holandês conhecido pelo uso das cores e pelo domínio da luz em seus quadros.

${ }^{77}$ A técnica do chiaroscuro foi desenvolvida por Leonardo Da Vinci e consiste em trabalhar luz, brilho e sombra na representação de um objeto sem usar linhas de contorno, apenas pelo contraste entre figura e fundo. A técnica ganharia mais destaque na pintura barroca do Seicento com Rembrandt e Caravaggio. Da Vinci desejava obter relevo com a utilização científica da luz e das sombras. "Em seu Tratatto, ele diz, sob o título O que é mais difícil, sombra e luz ou bom desenho: 'Sombras têm seus limites em certos pontos determinados. Aquele que ignora isto produzirá obra sem relevo; e o relevo é o ponto alto e a alma da pintura'."(CLARK;2003:156)
} 


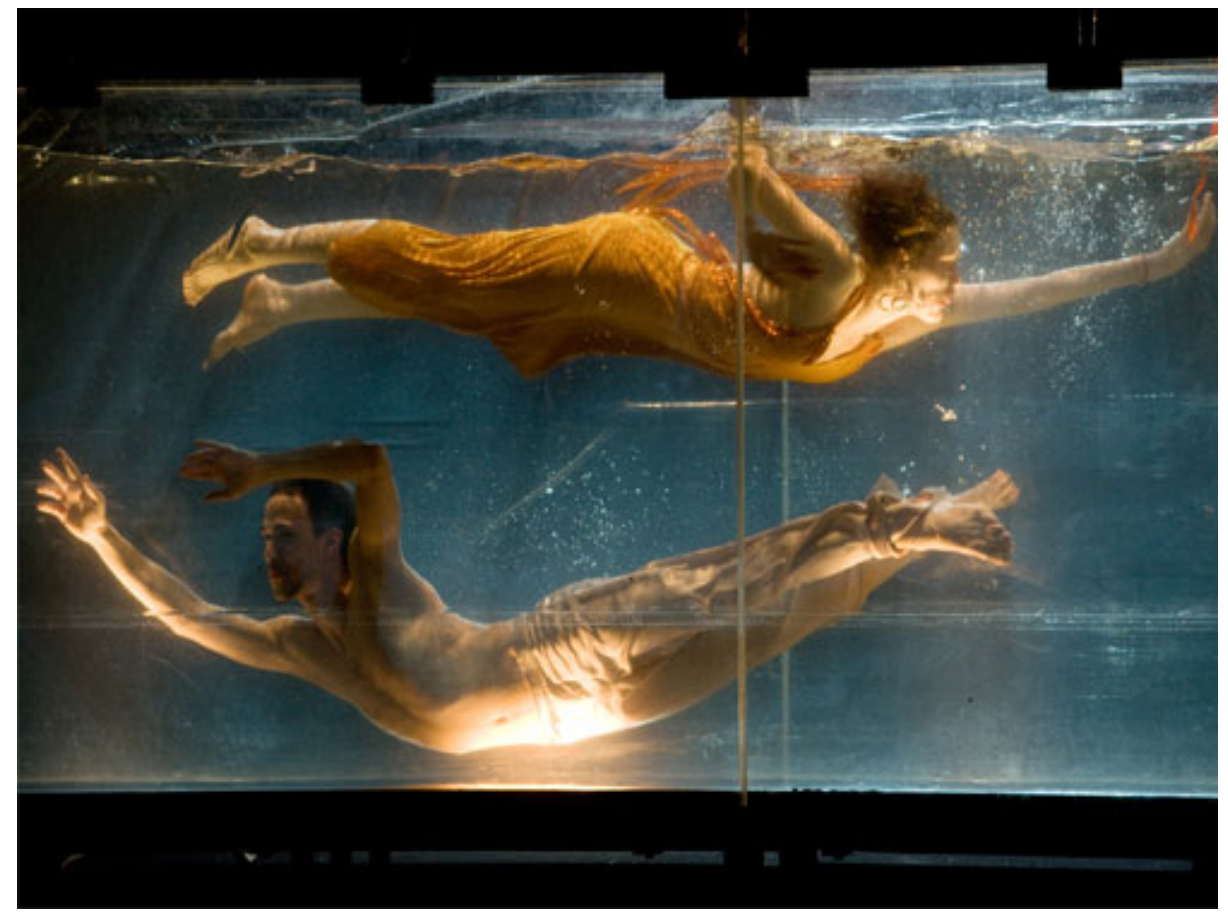

Figura 13: Dido \& Aeneas - Waldbühne (2011)

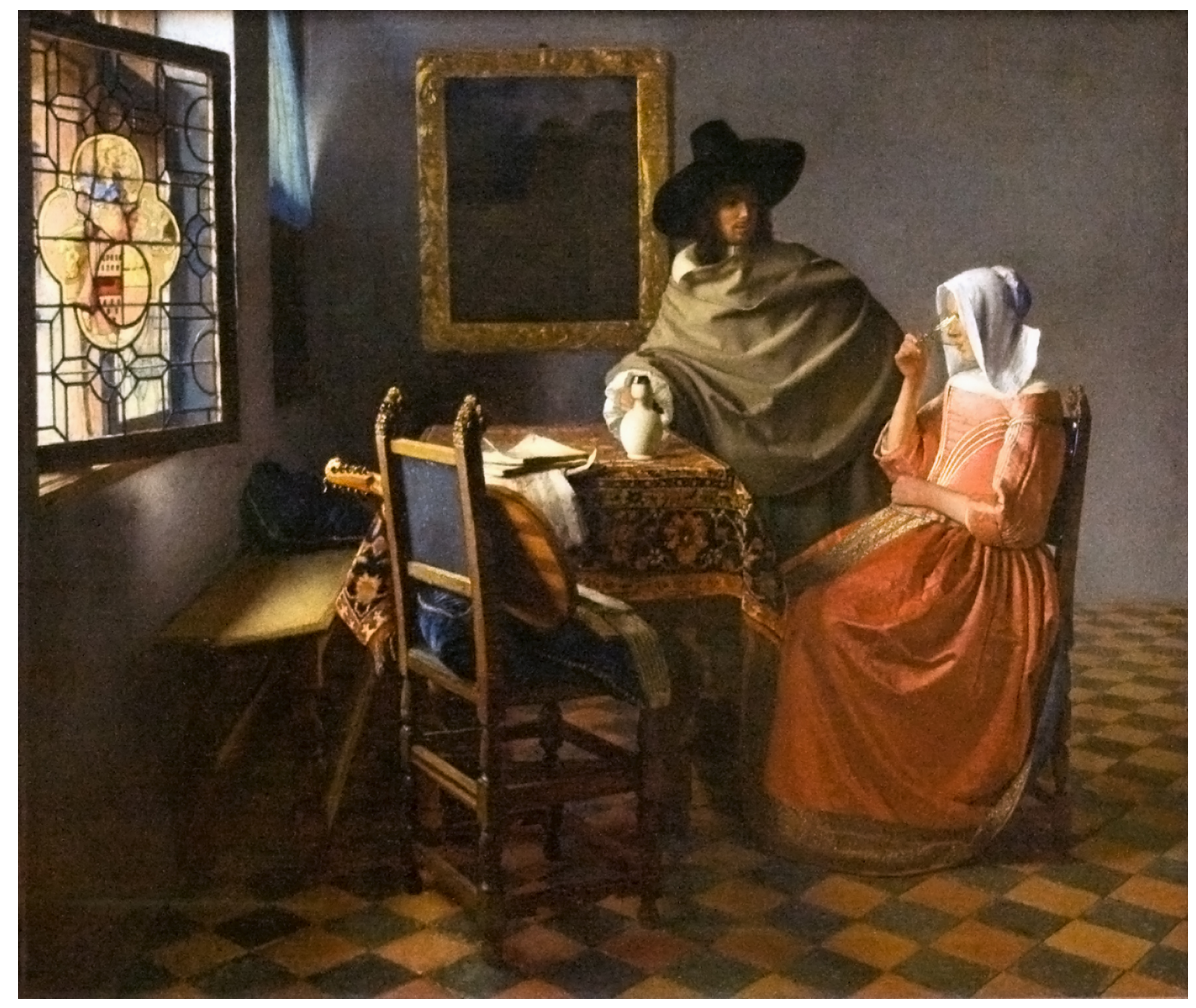

Figura 14: Homem, mulher e vinho (1658 - 1660), JohannesVermeer 
O que podemos apreender da obra de Sasha Waltz para um pensamento da artemídia e da relação homem-máquina nesse contexto? Certamente a dança e o teatro lidam há mais tempo com questões relacionadas ao corpo. É mais comum que essas manifestações dialoguem com as artes visuais que o contrário, na escolha de cores, detalhes de cenário, vestuário, entre outros. As interfaces que venham a propor interações fora da tela, envolvendo o corpo, irão propor experiências cinestésicas e, a partir daí, pensar o aspecto visual passará por um pensamento do movimento, envolvendo o usuário. Além disso, a proposta do ZKM mostra que a artemídia ou a arte em sua relação com a tecnologia, o computador e a eletrônica, que desde meados dos anos 1950 quando começaram os primeiros experimentos na área era observada como uma arte à parte, se integra cada vez mais às outras manifestações artísticas, mostrando uma mudança de atitude nesse sentido, intensificando o aspecto híbrido, tão característico das obras contemporâneas.

Não apenas no ZKM observamos tal fenômeno. Visitando a $12^{\mathrm{a}}$ Bienal de Arte Contemporânea de Lyon de 2013, também em dezembro do mesmo ano, pudemos encontrar obras de constituição plural, em que a apropriação de mídias diversas, recursos tecnológicos e eletrônicos (principalmente o recurso da projeção) compunham, junto às formas tradicionais, ou analógicas de arte uma obra complexa que, de modo geral, ocupa grandes espaços. Às vezes uma única sala abrange apenas uma obra que se mostra em estações ou partes, criando uma narrativa não-linear por meio do diálogo entre diferentes técnicas, diferentes objetos cotidianos dispostos muitas vezes como esculturas, entre as quais o observador deve caminhar, traçando um percurso próprio. A obra pede o percurso. Só se completa mediante esse movimento, raras vezes identificado pelo artista, para que o participador possa construir sua própria ordem de leitura da narrativa.

Dentre as várias obras que se compunham de forma semelhante à descrita acima, uma em especial me chamou a atenção, Il était une fois ... (2013), de Antoine Catala ${ }^{78}$. A obra pode ser considerada uma instalação híbrida que ocupava uma sala do prédio do Museu de Arte Contemporânea de Lyon e era composta de cinco elementos, ou estações. Cada estação estava conectada à outra por meio de fios de eletricidade, necessários ao funcionamento da obra e que permaneciam deliberadamente expostos. A primeira parte era composta por uma instalação com areia no chão e um aparato composto de um galão d'água, uma máquina de vapor e um pequeno projetor. De tempos em tempos a máquina soltava o vapor que se transformava numa efêmera tela para a imagem de uma ilha que vinha do projetor. A mesma

${ }^{78}$ Antoine Catala $(1975-$ ). Site do artista: < www.aaaaaaa.org/ > 
imagem se encontrava projetada em grande dimensão na parede em frente a essa instalação. A segunda estação da obra era constituída por uma espécie de totem em que víamos a imagem do personagem E.T. do filme de Steven Spilberg (1982). O totem era formado por um prisma espelhado que refletia a imagem da cabeça do personagem em movimento que, por sua vez, se encaixava perfeitamente a um pedaço de escultura contendo o torso e o dedo de E.T., dando a ilusão de vermos a imagem completa que, na verdade era parte física, parte projetada. A terceira parte se compunha de uma pequena tela inflável sobre um pedestal com um projetor na frente, em que se via uma imagem da lua, justaposta à projeção da letra "l" entre parênteses, associada ao som que se assemelhava ao de uma máquina de oxigênio, acompanhando o movimento da tela. O quarto elemento era uma escultura de um fígado atravessado por um projetor. Por fim, a última instalação era composta de três pontos vermelhos sobre finos suportes dando a impressão de estarem suspensos. Eles enchiam e esvaziavam, emitindo o som dessa ação, similar ao da tela inflável de uma estação anterior.

No primeiro percurso, a busca foi por compreender a mensagem do artista. O movimento de inflar e desinflar encontrado em dois elementos, acompanhados do som, que remetiam à respiração, assim como a escultura do fígado, um órgão vital para o ser humano, além dos fios de eletricidade que ligavam uma estação à outra, como que conectando-as, remeteram a sensações de ameaça à vida. Aliado a isso, a imagem da ilha, e a representação material dela por meio do montante de areia, bem como a imagem da lua e do E.T., a relacionavam, de certa forma, à temática do universo e do meio ambiente. Essa era a sensação geral que a obra passava: o mundo está doente. Essa foi, pelo menos, a primeira leitura, realizada no decorrer do percurso. Ao cruzar de novo a sala em direção à entrada, encontrei novamente o nome da obra e a frase que a acompanhava: "No começo existia a palavra. A palavra que abre a porta a todas as histórias". A "palavra” que abre todas as histórias é essa mesma: Era uma vez, ou, em francês, o nome da obra ali exposta: Il était une fois... Foi possível perceber o jogo de palavras entre fois (vez, em português) e a escultura do fígado, que em francês é foie, mas se pronuncia tal como fois. E, sem mais delongas, o último percurso da obra findou, na crença de havê-la decifrado.

Meses depois, ao pesquisar mais sobre o artista e a obra em si, descobri finalmente o jogo de palavras proposto por Catala. A instalação da ilha (île, em francês) se referia ao artigo inicial do título da obra: Il. O totem do E.T, à segunda palavra était. Na estação da projeção da lua, sobreposta à letra "l" entre parênteses, que também pode ser lida como o número um, encontramos o une da frase. Em seguida, a brincadeira entre fois e foie e, por fim, os três 
pontos suspensos que inflam e desinflam: as reticências... - Il était une fois... ou Era uma vez..., em português.

Nesse instante colocamos em dúvida a primeira interpretação acerca da obra, classificando-a como tola. No entanto, logo em seguida, percebemos que essa era uma interpretação possível, de acordo com um dos vários percursos possíveis daquela narrativa proposta de forma instalativa e que dialogava com as experiências pessoais do participador, provenientes talvez de outras informações que estavam mais evidentes na memória no momento de contato com a obra - entre outras possibilidades que possam ter moldado a percepção. Outros participantes podem tê-la interpretado de forma completamente diferente. Arlindo Machado ressalta que, enquanto na prosa expositiva clássica o percurso do pensamento é quase sempre fixo e estabelecido pela linearidade das frases, num aplicativo hipermídia a navegação permite a livre associação das unidades, todas legítimas:

\begin{abstract}
A ligação expressiva dos diversos signos verbais, visuais, acústicos e táteis que compõem o aplicativo permitem estabelecer relações significantes entre eles, e dessa maneira, passar do concreto ao abstrato, do visível ao invisível, do sensível ao inteligível e da mostra à demonstração. Nesse sentido, um aplicativo de hipermídia jamais exprime uma determinada linha de raciocínio. Ele se abre para a experiência plena do pensamento e da imaginação, como um processo vivo que se modifica sem cessar, que se adapta em função do contexto, que, enfim, joga com os dados disponíveis. (2001:109)
\end{abstract}

Antoine Catala não dispõe as estações que compõem a obra em ordem, de forma que a instalação da ilha, que representa o artigo inicial do nome da obra, seja a primeira, num percurso pré-determinado e assim sucessivamente. Na verdade, no percurso realizado por mim, ela foi a quarta parada, mas poderia ter sido visitada em qualquer ordem. $\mathrm{O}$ transitar pela obra é um convite a se deslocar pelo espaço, numa atitude de abrir-se à experimentação. Essa noção de movimento, aparentemente guiou o artista também na escolha da mecânica de suas esculturas. Em uma entrevista a respeito da obra, ele diz: "Fora o fígado, tudo é cinético, se mexe, para insistir sobre a ideia de metamorfose. [...] O que me interessa, antes de tudo é a espacialização, a imagem sai da tela para se tornar um objeto e uma relação física.,79

A obra, portanto, é híbrida, propõe uma relação com o corpo por meio do deslocamento no espaço e é esse deslocamento que constitui o ritmo entre as partes e que irá conferir algum significado. É o participador que controla o ritmo por meio de seu movimento e trajeto escolhido, insinuando um possível significado à obra que é aberta, no sentido que propõe

\footnotetext{
${ }^{79}$ CATALA, Antoine. Standard Magazine: “Antoine Catala: s'impregner de la banalité”. Entrevista concedida a Patricia Maincent em 23 de dezembro de 2013. Disponível em: $<$ http://www.standardmagazine.com/antoine-catala-interview/> Acessada em 18/02/2014.
} 
Umberto Eco (2007), priorizando seu aspecto experimental e em constante transformação. Fluxo subjetivo em diálogo com o objeto, promovendo uma possível visão de mundo e que aparenta ser a forma como iremos lidar com as imagens das interfaces por vir que, tal como propõe Antoine Catala, "saem da tela para se tornar objeto".

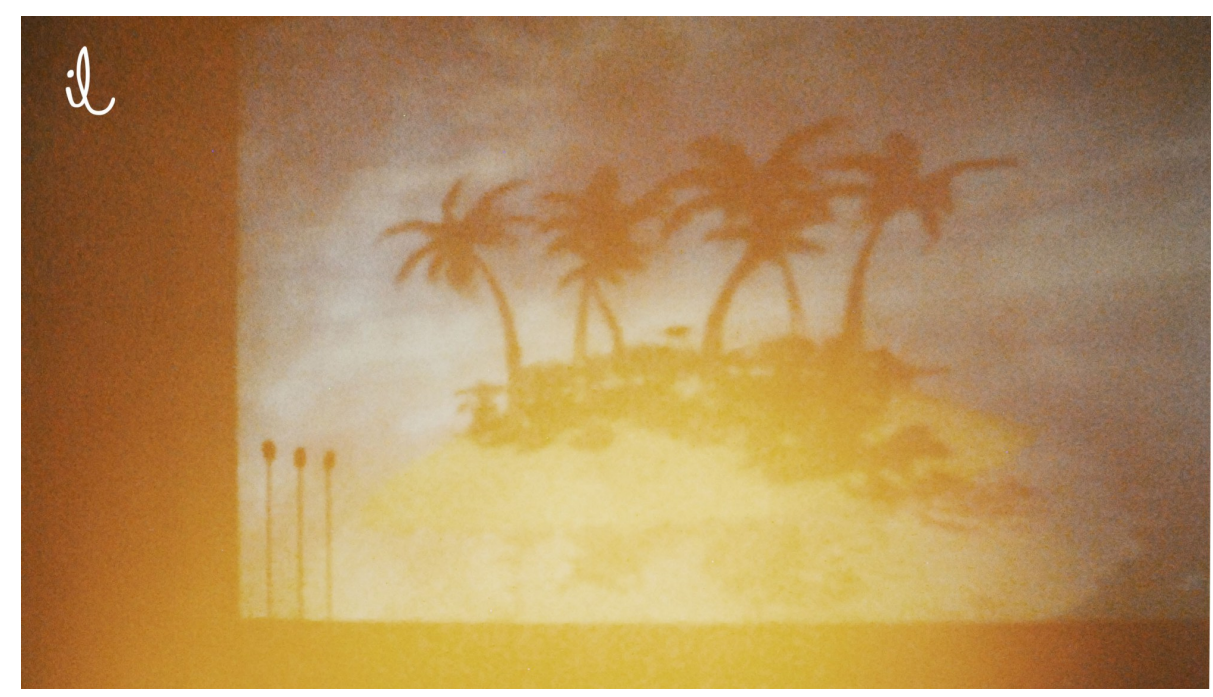

Figuras 15 a 19 : Sequência de imagens da instalação Il était une fois (2013)

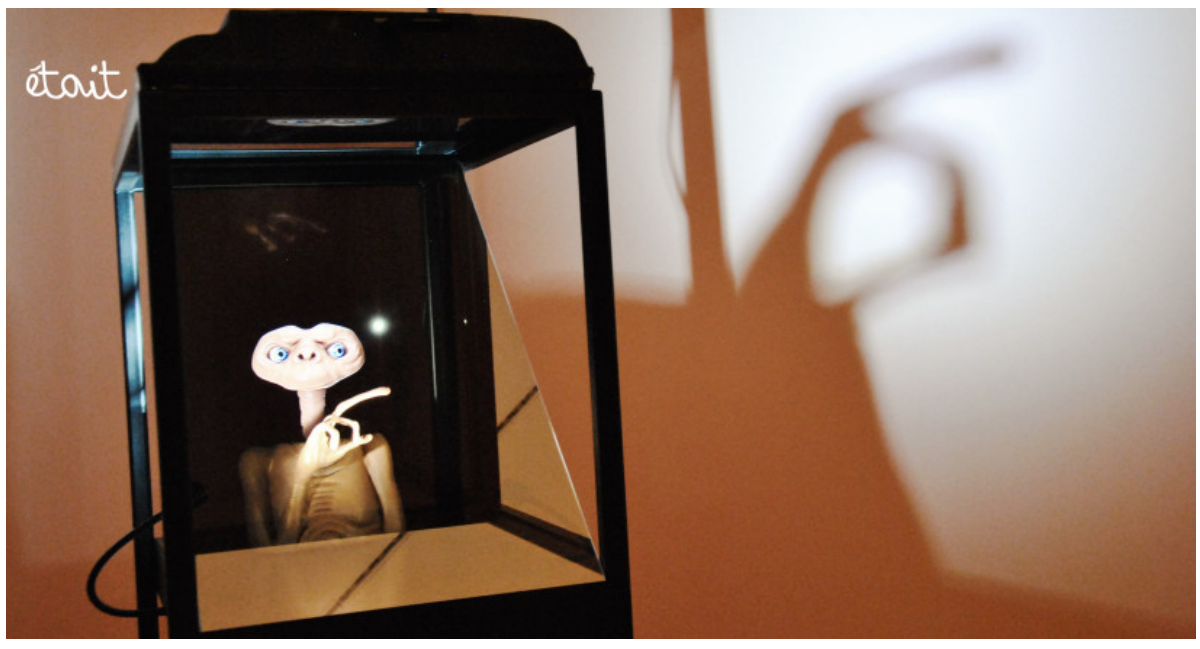

Figura 16 


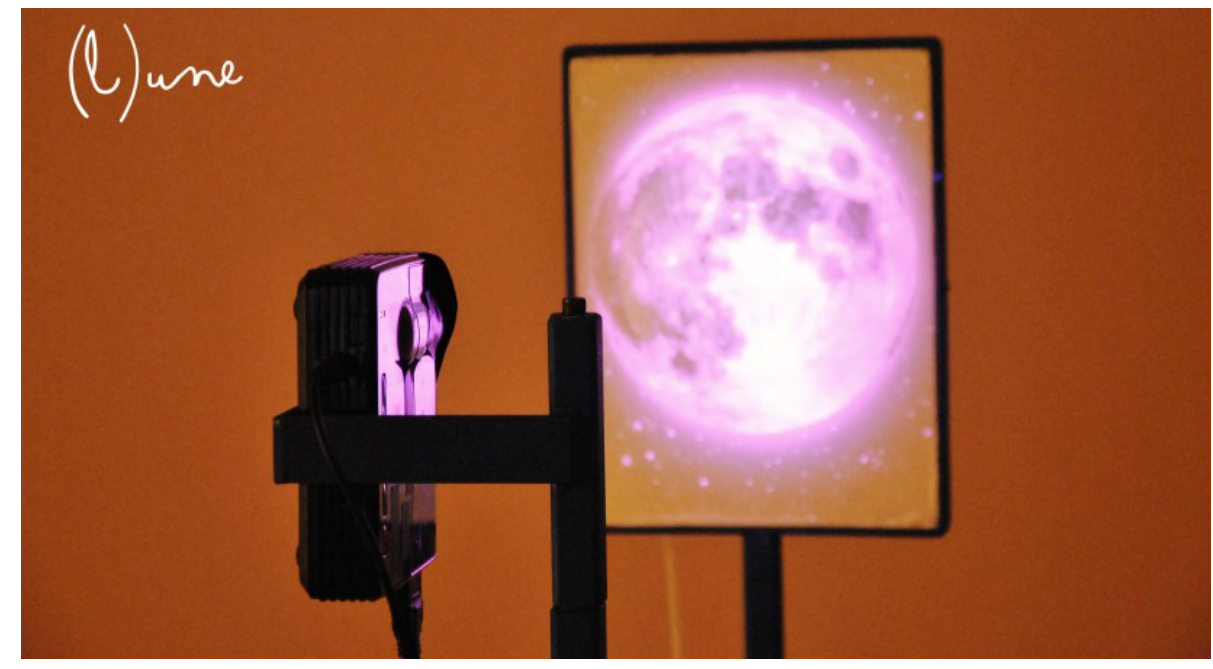

Figura 17

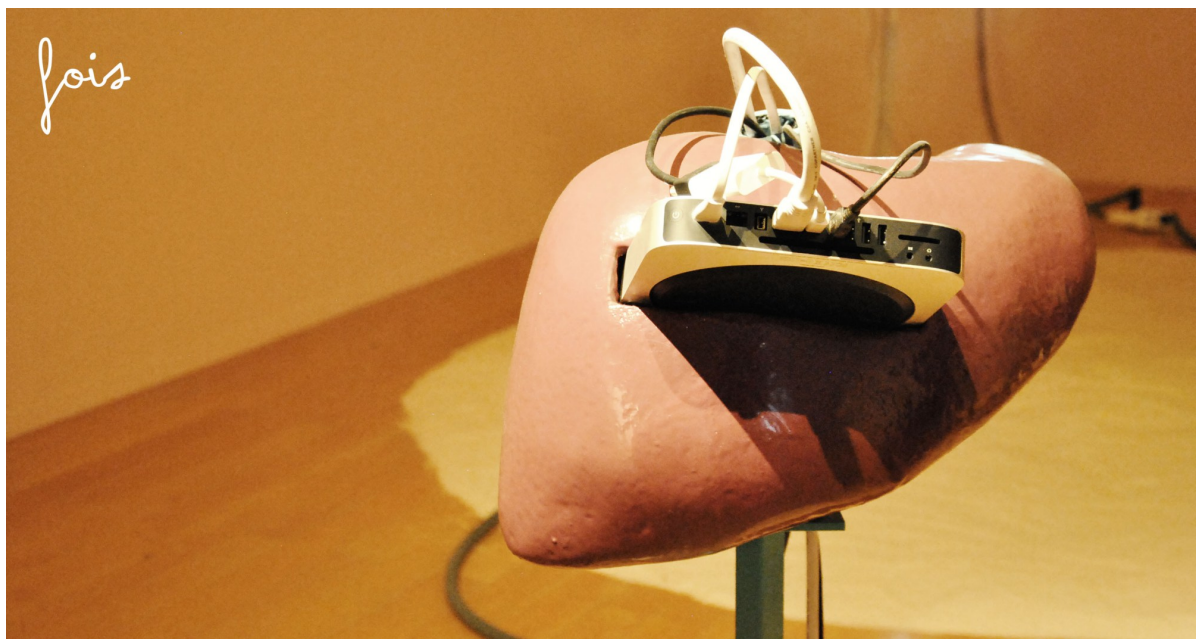

Figura 18

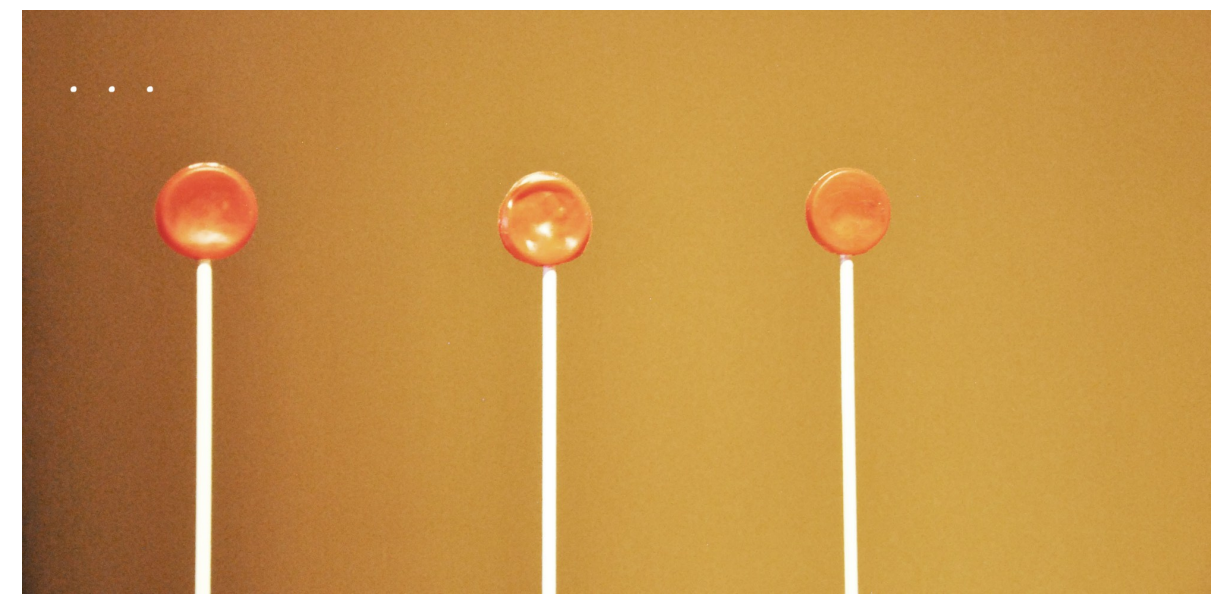

Figura 19 
Assim, se retomarmos a relação homem-máquina como uma importante questão a ser discutida quando falamos em hibridismo a partir da estética do fluxo (no que concerne as obras de artemídia), o que essa obra quer nos mostrar, ao propor percursos que oscilam entre o real e o virtual, é que essa ligação não necessariamente leva à criação de um "admirável mundo novo", em que nos comportaremos de forma totalmente programada tal qual os ciborgues de ficção científica. Il était une fois (2013) nos mostra que as escolhas que fazemos de percurso (do corpo no espaço, em relação à imagem), conferem significados diferentes a uma obra aberta, seja esse corpo "puro" ou ampliado por próteses midiáticas.

Dessa forma, podemos compreender como, por mais conectados que estejamos a uma máquina, a dimensão humana não deixará de existir. A percepção continuará a se ligar às sensações, e as emoções e afetos permanecerão como base das atitudes de qualquer avatar, dispositivo ou interface. Em realidade, o pensamento a partir da separação não fará sentido: humano ou máquina. Daí que devemos compreender o hibridismo que se manifesta em determinadas obras de artemídia como uma maneira natural de transitar entre as diversas naturezas da informação, da imagem, do sujeito e do objeto. Essa naturalidade se dá em função do ritmo subjetivo da oscilação entre esses diferentes estados, assumindo o hibridismo em si. Como propõe Suzete Venturelli e como também acreditamos, o que está surgindo, mais do que um ciborgue desprovido de gênero, como propõe Le Breton (2013), por exemplo, é um corpo mutante, meio carne, meio máquina, que flutua entre essas e outras tantas possíveis configurações, já que a carne do mundo pode agora se transformar em bits e, percorrendo as redes da internet, não mais se restringir aos limites físicos do espaço, redefinindo-se constantemente - mas sem deixar de lado sua humanidade.

Outra obra que busca criar uma relação simbiótica com o interator ${ }^{80}$, é Caracolomobile $(2010)^{81}$, de Tania Fraga ${ }^{82}$, apresentada na quinta edição da Bienal Internacional de Arte e Tencologia do Itaú Cultural, Emoção Art.Ficial, em São Paulo. A obra se constitui num

\footnotetext{
80 "Nas situações simuladas por computador, os ambientes e seres virtuais que aparecem na tela podem ser alterados, introduzidos, redispostos e destruídos por esse mega-personagem que é o usuário, ou seja, o sujeito imerso, a "narrativa" (ou seja lá o que for que acontecer nesses espaços e tempos virtuais) não pode ser mais definida a priori. Ela deve, pelo contrário, aparecer como um campo de possibilidades governado por um programa, ela deve existir como um repertório de situações manejado por uma espécie de máquina de simulação, capaz de tomar decisões em termos narrativos, a partir de uma avaliação das ações exercidas por esse receptor ativo e imerso (o usuário) que vamos a partir de agora passar a chamar de interator. Em outras palavras, nos novos ambientes de imersão possibilitados pelos simuladores de acontecimentos virtuais, boa parte das estratégias narrativas que habitualmente eram atribuídas a um sujeito narrador interno à diegese passam agora a ser assumidas por dois sujeitos simultaneamente: de um lado, o interator, sujeito físico que se deixa imergir na simulação, espécie de demiurgo que faz desencadear os acontecimentos da diegese; de outro, um sujeito-SE, um programa de geração automática de situações narrativas, que dialoga com o primeiro.”(MACHADO;2001a)

${ }^{81}$ Disponível em: < https://www.youtube.com/watch?v=ya4N2AcXyE8 >. Acessado em 19/02/2014. Vídeo em DVD em anexo: pasta 'Capitulo 03 >> 09. Caracolomobile.mp4

${ }^{82}$ Tania Fraga é artista, pesquisadora associada da UnB. Site da artista:

$<$ http://wiki.taniafraga.art.br/index.php?title $=\mathrm{P} \% \mathrm{C} 3 \%$ A1 gina_principal $>$
} 
organismo artificial construído em titânio, semelhante a um caracol e que tem a capacidade de reconhecer estados emocionais humanos, respondendo a eles por meio de movimentos e sons. Tania afirma que pensar a estrutura do protótipo bem como a escolha do material que o constituiria estava muito ligada à proposta estética que tinha em mente. A máquina precisava ser flexível, leve e de simples funcionamento, desempenhando movimentos orgânicos. Ela também precisava ser vista de todos os lados.

A relação com o participador se estabelece por meio do uso de um capacete neural que capta, através de 16 sensores biométricos neurais, as flutuações da mente do interator: expressões faciais, estados afetivos e uma série de palavras pensadas pelo usuário. Ao final dos meses em que a obra esteve exposta na Bienal, a artista diz ter percebido um comportamento interessante. Os usuários começaram a perceber como podiam controlar as reações da máquina se conseguissem controlar as próprias emoções e, a partir daí, se propunham deliberadamente a tal tarefa. Essa é uma constatação sobre a qual ainda se faz necessário desenvolver vários estudos, no entanto, mostra como será possível promover a hibridação entre humano e máquina, levando em conta o importante papel das emoções humanas nessa relação.

Diante de tantas mudanças e possibilidades, as obras de artemídia acabam propondo uma nova estética, de uma arte ainda não institucionalizada, como afirma Venturelli (2011: 164), em que acreditamos que o estado natural é o da oscilação, do movimento, ou fluxo: entre humano e máquina, entre arte e mídia, entre artista e participador e tantos outros entres. Para nos aprofundarmos na natureza física e ontológica dessas relações, propomos, em seguida, um recorte sobre como esse hibridismo se manifesta na prática, por meio da observação da relação entre luz e sombra e entre o real e o virtual em obras de artemídia.

\subsection{Luz e sombra: atualização barroca na interação com o participador}

Pensar a luz como matéria-prima da arte parece difícil devido a sua característica impalpável. No entanto, sem luz, não há visão e, portanto, uma parte importante da percepção das obras de arte já estaria comprometida. Aristóteles (2006:87) acreditava que a escuridão é luz em potência e vice-versa. Para o filósofo, ambas seriam da mesma natureza e a passagem de um estado ao outro se daria pelas delimitações da forma, resgatadas da relação entre luz e sombra.

Por sua característica fluida, a luz não é um material fácil de se trabalhar. Podemos perceber que os artistas, ao trabalharem com a luz, muitas vezes acabam por enveredar pelo 
caminho da arte híbrida, associando diferentes técnicas e formas de arte, pois apenas com o apoio de vários suportes é que se torna possível, a uma primeira vista, moldar e reter a luz, criando formas - em sua maioria abstratas. Com o aumento da participação do observador — agora também possível criador —, no contexto da artemídia, essa relação das artes com a luz na criação de imagens se transforma, bem como transforma o próprio conceito de estética, que abandonou o apego apenas à forma para se tornar fluxo. Para entender essa transição, desde a modernidade à contemporaneidade, faremos uma breve observação do trabalho de dois artistas e suas obras híbridas realizadas a partir da luz: Laszlò Moholy-Nagy e Anthony $\mathrm{McCall}^{83}$.

László Moholy-Nagy, assim como Kandinsky e Paul Klee, também foi professor da Bauhaus. Na década de 1920, fazendo uso da fotografia como material artístico ${ }^{84}$ de seus experimentos, principalmente pela técnica do fotograma ${ }^{85}$, ele buscava conceber uma estética da luz como forma de criação de imagens sem o uso de pigmento, aplicando fundamentos de composição do design na busca de uma pintura abstrata, conseguida pela captura da luz por meio da técnica fotográfica.

Segundo Baqué (In: MOHOLY-NAGY;2005:17), para Moholy-Nagy a luz "é o fio de Ariadne de uma obra aplicada à pintura, à fotografia e ao cinema, mas também à cenografia $\mathrm{e}$ ao design [...] qualquer arte só adquire sentido na medida em que mostra a luz na modalidade que lhe é própria. A luz como matriz da arte, a arte como arte da luz." O professor da Bauhaus acreditava que "cada forma luminosa, cada tipo de luz modulada extrai e faz ver as coisas." (ROUILLÉ; 2009:267). Realizar uma imagem consistiria em "atualizar, nas formas e nas matérias fotográficas tangíveis, uma outra forma virtual de luz" (Ibidem:267), dando origem a novas visibilidades. Cada corrente artística, com suas características próprias, poderia, portanto, ser vista como uma moduladora de luz diferente. Para realizar suas experiências, o professor e artista chegou a construir uma máquina, o modulador espaço-luz, criando formas pelo jogo entre luz e sombra conseguido pelo aparelho, composto de espelhos e partes metálicas que se movimentavam.

Para Moholy-Nagy, as coisas, na arte, não são iluminadas pela luz incidente, mas pela luz modulada. A partir dessa noção, acreditamos que a aliança realizada pelo teórico,

\footnotetext{
${ }^{83}$ Anthony McCall (1940 - ). Site do artista: www.anthonymaccall.com

${ }^{84}$ A noção de fotografia como material (matériau) da arte que usamos nesta pesquisa está presente no pensamento de André Rouillé (2009). Segundo o autor, a fotografia usada apenas como vetor ou ferramenta (medium) é diferente de uma fotografia usada para a criação, trabalhada e que exige um saber-fazer propriamente fotográfico essa, sim, uma fotografia tida como material (matériau) da arte (2009:326)

${ }^{85} \mathrm{O}$ fotograma constitui uma imagem obtida somente com a luz, sem o auxílio da câmera fotográfica. A composição com a luz se dá através de sua passagem por objetos dispostos sobre um papel fotossensível.
} 
fundamentada em princípios do design, da fotografia e da pintura abstrata - no caso dos fotogramas - ou em princípios do design, cinema e pintura abstrata - no caso dos filmes experimentais - , possa se constituir numa relação híbrida capaz de modular a luz.

Nos seus estudos, Moholy-Nagy estava em busca de uma pintura da transparência, ou livre de toda a pressão representativa. Para alcançar esse objetivo, ele acreditava que deveria experimentar pintar com a luz e não com o pigmento. Daí o seu interesse pela fotografia e seu uso como material que tornaria possível uma obra mais fluida, partindo dos princípios conceituais da pintura abstrata, aliada aos princípios de composição do design - o que resultaria em imagens híbridas em termos de referências, técnicas e estética. O professor da Bauhaus procurava, ainda, substituir uma pintura estática pelo jogo de projeções luminosas de diapositivos, usando técnicas do cinema para dar movimento à manipulação da luz. Essa foi a maneira encontrada por ele para interpretar a obra pictórica de Malevich, reinventando-a ou atualizando-a, ao explorar um jogo de luminosidades já encontrado na obra Quadrado branco sobre fundo branco (1915), em que ele diz ver "uma tela de projeção capaz de refletir os jogos de luz." (MOHOLY-NAGY; 2005: 19).

O livro Pintura, fotografia e cinema (2005), escrito em 1925 por Moholy-Nagy — no qual ele investiga as modulações da luz nessas áreas, relacionando-as entre si —, acaba fundando um novo movimento fotográfico na Alemanha, a Nova Visão. Além de se constituir numa corrente estética, a Nova Visão propõe uma nova prática do ver, que aumente as capacidades sensoriais do homem, ampliando sua visão limitada. Nas imagens produzidas pelos artistas do movimento, pode-se observar uma profusão de tomadas oblíquas ou descentralizadas; de composições geométricas sem direção e sem eixo que refletiam uma preocupação com o estudo das formas, tão presente nos ensinamentos dos fundamentos de design na Bauhaus. Eles faziam uso da luz como material artístico, captada sobre um suporte fotográfico, transformando a Nova Visão (por sua vez precedida pelo movimento Pictorialista, mas com uma proposta totalmente diferente, ao buscar valorizar uma linguagem tipicamente fotográfica), num dos primeiros movimentos a anunciar uma aliança entre arte e fotografia, que só viria a se consolidar sessenta anos mais tarde.

Os estudos de Moholy-Nagy, usando a luz como vetor de uma arte híbrida, constituem uma referência importante até os dias de hoje. No entanto, devemos contextualizar cultural e socialmente o período em que suas experiências foram feitas para entender a estética resultante delas. O artista mesmo dizia que "a forma também segue aos desenvolvimentos técnicos e artísticos existentes, incluindo a Sociologia e a Economia.” (2005:237). 
Moholy-Nagy está inserido no contexto de uma sociedade modernista, num período de importantes rupturas com concepções de mundo e representação que vigoravam há séculos pelo menos desde o Renascimento. De lá pra cá, outras rupturas aconteceram. O desenvolvimento da tecnologia e da internet nos trouxe a uma sociedade conhecida como a sociedade da informação. Passamos de um mundo de coisas a um mundo de acontecimentos; de incorporais (ROUILLÉ; 2009:175). Nessa sociedade líquida - usando a expressão difundida por Zygmunt Bauman _-, em que tudo é volátil, passamos de uma estética das formas para uma estética do fluxo. $\mathrm{Na}$ estética do fluxo, obra e sujeito estão em constante movimento, rompendo com a forma fixa e imutável da estética da forma e estabelecendo uma relação que interfere no comportamento da obra.

O observador não apenas assiste mas participa e se funde à obra. E, cada vez mais, com a convergência entre arte e mídia, ele se torna também criador. Queremos repensar a luz como vetor de uma arte híbrida neste contexto contemporâneo. Mas, antes de chegar aí, veremos como se deu essa relação entre a luz e as imagens num contexto pós-moderno. Para tanto, escolhemos o trabalho de Anthony McCall, que já introduzia, na década de 1970, a questão da participação, fazendo com que suas esculturas de luz estivessem sempre em transformação só se completam pela presença de quem participa dela.

McCall usa a luz como matéria-prima para uma arte híbrida entre escultura, cinema, design e instalação, de forma a chamar o observador para a experiência de fruir sua obraevento. O artista organiza instalações em que usa o projetor de cinema para gerar formas geométricas específicas, que vão sendo construídas ao longo de um tempo determinado de modo a tornar a própria projeção numa escultura impalpável, com o apelo visual de um volume sólido tridimensional, mas, feito, em realidade, apenas de luz. O artista convida o observador a participar da obra, adentrando os solid light films com seu próprio corpo. Ao usar o projetor de cinema, eliminando a imagem figurativa - por meio da abstração buscada no design das formas que são projetadas - e, consequentemente, subvertendo a narrativa tradicional, McCall chama atenção para o feixe de luz em si, fazendo com que o espectador observe o projetor e não a tela - escultura impalpável (DOBAL; 2009:44). Suas imagens constituem, portanto, um híbrido construído sobre referências de diversas técnicas, estéticas e linguagens que incitam à participação.

Podemos citar algumas de suas obras como Light describing a cone (1973), por exemplo, constituída a partir de um feixe de luz que projeta a construção de um círculo no decorrer de 30 minutos. É o próprio feixe de luz que vai formando o cone e a escultura imaterial no espaço escuro, durante o tempo da projeção. Outra obra importante desse período foi Long 
film for four projectors (1974), em que quatro projetores mostram linhas retas que se movimentam e se cruzam em uma sala escura, formando quatro triângulos que se interpenetram e que parecem ser tão sólidos quanto lâminas. Algumas outras obras desenvolvidas no início dos anos 1970 foram: Long Film for Ambient Light (1975) e Room with Altered Window (1973), em que o artista usa feixes de luz provenientes da luz natural que entram pela janela durante o dia, e não de um projetor de filme.

Mais de vinte anos se passaram até que Anthony McCall retomasse suas esculturas de luz, ou seus solid light films. Em 2002, ele volta a trabalhar as formas abstratas projetadas no escuro, sempre valorizando o feixe de luz emitido pelo projetor. A diferença é que, nos anos 1970, os filmes, e as esculturas resultantes de sua projeção estavam baseados apenas em linhas circulares, como é o caso de Line describing a Cone (1973), ou linhas retas como em Long film for four projectors (1974). Ao retomar seu trabalho, McCall introduz, até mesmo pelas facilidades do computador, uma linha ondulante, híbrida das duas anteriores (EAMON; 2005: 54), como é o caso de Doubling Back (2004).

Os esboços e estudos prévios realizados para cada um dos seus solid light films deixam clara, também, a sua formação em design e a preocupação com a forma abstrata. No entanto, para além da forma, McCall procura fazer com que o observador a perceba pelo movimento, chamando à participação corporal ao propor atravessar essas formas impalpáveis num determinado espaço e tempo. Esse caráter participativo é a grande diferença que podemos destacar entre o trabalho de McCall e o de Moholy-Nagy.

Ao entrar em uma das esculturas impalpáveis de McCall, a obra, Face to Face IV $(2013)^{86}$, pudemos observar que as formas de luz e fumaça propostas pelo artista compunham esculturas tridimensionais que, apesar de sua transparência e fluidez, davam a sensação de construção de um espaço. Era possível distinguir um lado interno e outro externo à escultura e podia-se escolher adentrá-la ou não. Outro ponto que chama atenção, conhecendo a formação do artista em design, é que as formas que são projetadas nessa obra, e dão origem às esculturas, se assemelham a letras de uma tipografia aproximada à cursiva. Vemos surgir a letra "c", a letra "a", a letra "f", ou ainda a "x", sempre em duplas e em movimento, como se ele quisesse estabelecer um diálogo entre elas. O duplo, aliás, é uma característica da obra, composta de dois projetores em que a mesma forma é desenhada por ambos, de maneira que, em cada parede, estando uma de frente para a outra, temos o desenho de uma projeção e, ao lado, o foco de luz do outro projetor. Numa visão geral da sala, temos duas formas

\footnotetext{
${ }^{86}$ Obra visitada em dezembro de 2013 na galeria Martine Abucaya em Paris. Vídeo em DVD em anexo: pasta ‘Capitulo_03 >> 10.McCall_FaceToFaceIV.mp4
} 
impalpáveis tridimensionais, cruzando o ambiente, moldando-se conforme as mudanças nas imagens que se assemelham a letras. $\mathrm{O}$ observador pode se posicionar ora dentro de uma das esculturas, ora dentro da outra - também fazendo parte da projeção, por meio de sua silhueta —, ou ainda entre as duas, dependendo do percurso que decide traçar pela obra-instalação.

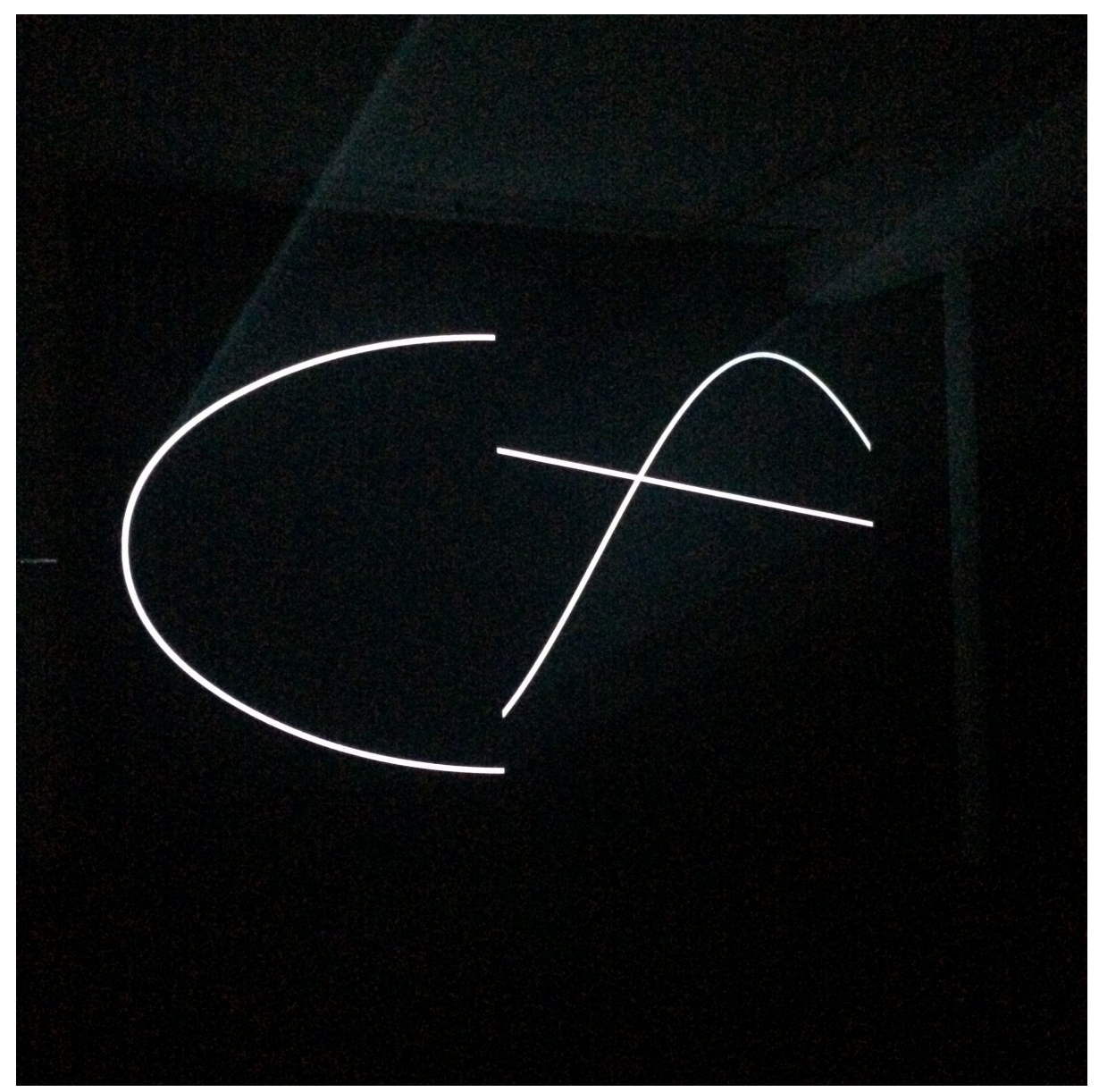

Figura 20: Face to Face IV (2013), Anthony McCall — formas realizadas pela luz na parede 


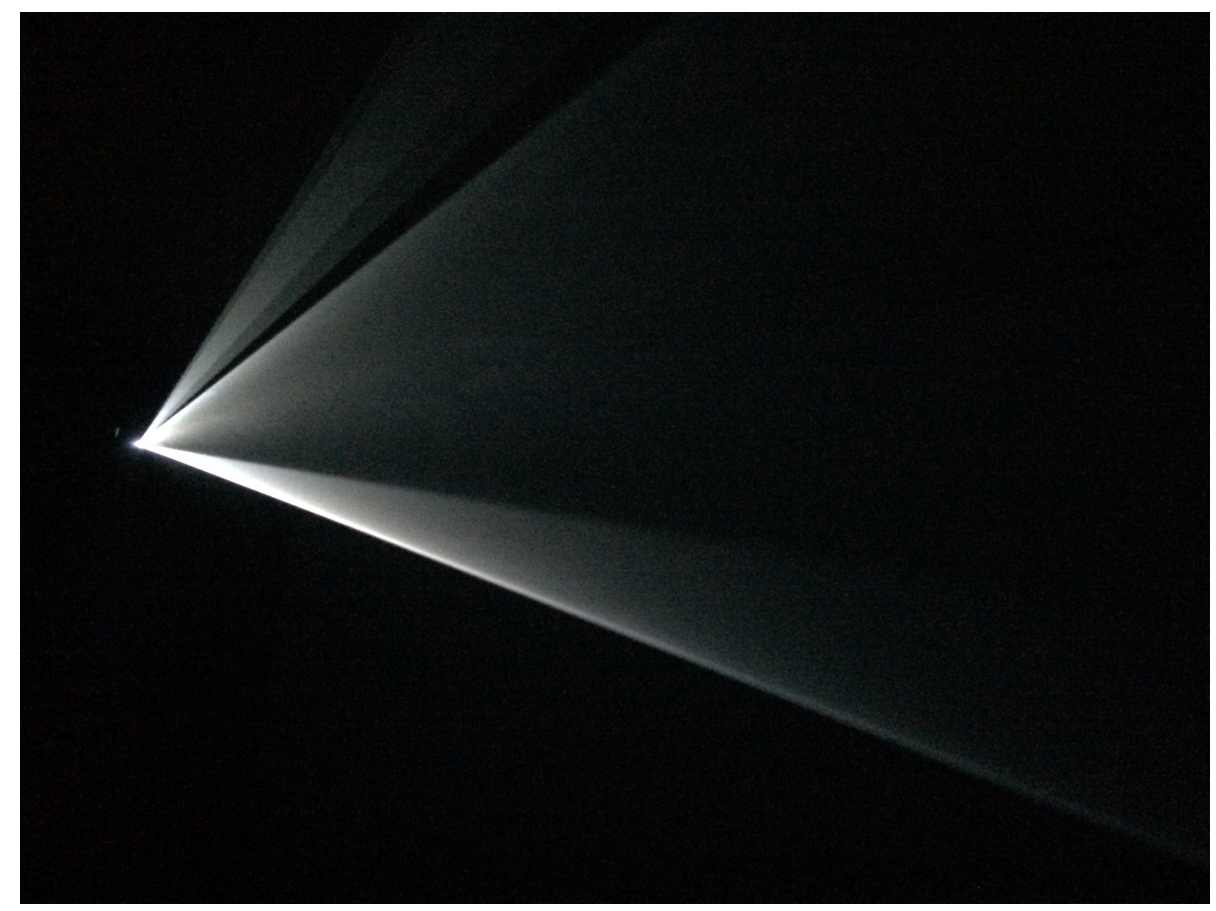

Figura 21: Face to Face IV (2013), Anthony McCall — foco de luz emitido do projetor

Para Rosalind Krauss, Moholy-Nagy e seu modulador espaço-luz constituiriam apenas uma contribuição de ordem tecnológica à noção convencional de espaço e tempo (KRAUSS apud LEGG;2004:3), pois ele não interferiu na relação com o observador, que permanecia passivo diante de suas obras. Outra diferença importante que podemos notar entre ambos artistas é que, apesar dos dois se preocuparem com a questão formal, que se sobrepõe à narrativa, e de trabalharem com uma matéria-prima impalpável, como a luz, Moholy-Nagy buscava sua materialização de alguma forma, como é o caso dos fotogramas ou ainda dos filmes que realizava usando seu modulador espaço-luz, por exemplo. Já McCall radicaliza ao máximo o aspecto imaterial, usando a própria luz como meio de expressão e de relação com o observador. O próprio suporte é impalpável.

As obras de McCall podem se constituir como performances, obras-evento que só se completam na relação com o tempo, o espaço e o participador. $\mathrm{O}$ artista procura valorizar mais o processo que o meio, pois acredita que a arte se realiza entre diferentes formas de expressão: a pictórica, ligada à imagem; a cinemática, ligada ao tempo e ao movimento; e a escultural, ligada ao espaço (MCCALL; 2005: 147-148 In: EAMON;2005) — o que reforça ainda mais o caráter híbrido de suas obras.

Se Moholy-Nagy já representou uma inovação durante o modernismo, ao pensar uma arte híbrida e de formas abstratas que se sobrepõem à narrativa, McCall deu continuidade a essa inovação ao propor uma obra também híbrida porém impalpável, esvaziando o papel do 
objeto de arte em si. Assim, o artista fortalece a existência relacional desse "objeto" com o espaço de sua exibição e com o espectador, que passa a perceber a obra como fenômeno tanto pelo espaço quanto pelo tempo. A arte, para McCall, não poderia mais se ater a um objeto preso em si mesmo (BAKER; 2006).

Percorrendo esse caminho podemos perceber como a estética da forma começa a dar lugar a uma estética do fluxo, em que sujeito e obra estão integrados. Assim, vemos que McCall, já na década de 1970, introduziu pontos importantes a serem pensados pela arte contemporânea. Uma das obras expostas no Féstival Némo, visitada no Espace Centquatre de Paris, em dezembro de 2013, tinha uma proposta semelhante às obras de McCall: Tropique $(2013)^{87}$, de Étienne Rey ${ }^{88}$. A sala de exposição, escura, permitia que distinguíssemos os raios de luz emitidos pelos projetores. O artista, no entanto, utilizava vários projetores espalhados pelo ambiente, todos concentrados na parede em frente à da entrada na sala. Ele não estendia o foco de luz até outra parede ou suporte, em que pudéssemos visualizar um possível desenho realizado pelo feixe luminoso. Além disso, diferentemente das obras de McCall, em que o som do projetor se destaca em meio ao silêncio da sala, Étienne Rey se apropria do som para criar um espaço sonoro para a obra, intensificado pela oscilação e volume.

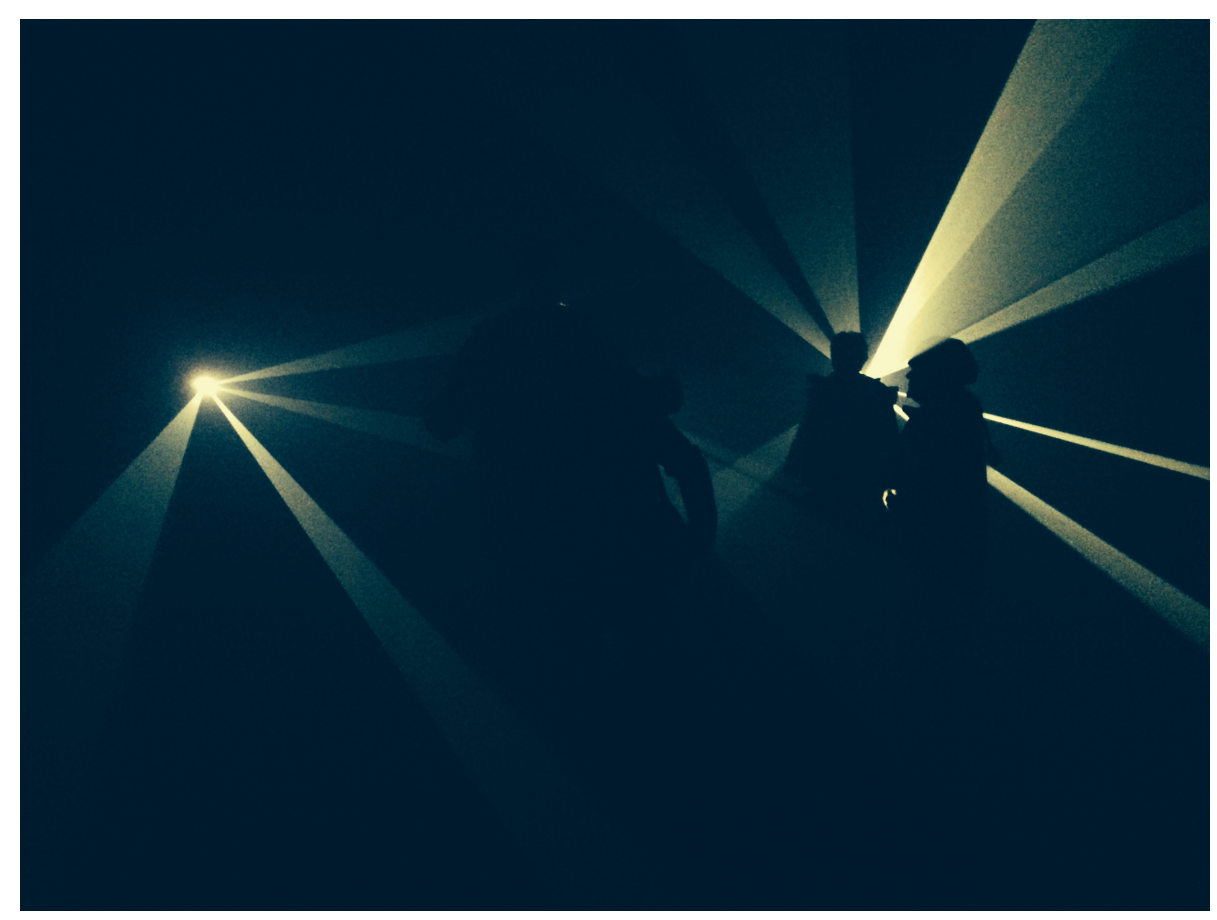

Figuras 22: Tropique (2013), Étienne Rey

\footnotetext{
${ }^{87}$ Disponível em < http://vimeo.com/groups/9784/videos/66161665 >. Acessado em 06/09/2014. Vídeo em DVD em anexo: pasta'Capitulo_03 $>>11$.Tropique.mp4

${ }^{88}$ Site do artista: http://ondesparalleles.org/
} 
O que podemos ressaltar como característica marcante não apenas das últimas obras que observamos, mas de todos os exemplos citados até aqui, é a importância da sombra, do espaço escuro, ou caverna, onde adentramos para, aí, encontrar o espetáculo luminoso. A relação entre luz e sombra foi muito utlizada pelo movimento Barroco, principalmente na pintura, como afirmamos anteriormente ao mencionar a técnica do chiaroscuro. Sobre essa relação nas obras barrocas, Leibniz ${ }^{89}$ afirmava que "a luz desliza como que por uma fenda no meio das trevas", criando uma espécie de dobra em que o claro sai do obscuro e não para de nele imergir (apud DELEUZE, 1991:54). A oscilação entre luz e sombra, no seu limite, cria uma textura que torna essa dobra perceptível, permitindo a criação de espaços impalpáveis e promovendo a ligação entre os opostos.

Na obra de artemídia, essa relação dialética é necessária para criar a sensação de imersão, já bastante explorada pelos panoramas do século XIX, em que, muitas vezes, o observador percorria uma passagem escura que levava à plataforma ou sala onde se encontrava uma grande tela iluminada. Oliver Grau (2003), ao descrevê-los, afirma que essa oposição entre claro e escuro era proposital para criar, nos primeiros minutos de contato com a obra, uma ilusão irresistível para que o espaço da imagem fosse vivenciado como real. No caso da artemídia, além de compor a ambientação, a relação entre luz e sombra constitui o próprio status ontológico da imagem, a partir do foco de luz do projetor (POPPER, 2007:29).

O fenômeno luminoso, segundo Frank Popper, é bastante explorado pelos artistas devido a presença de características físicas específicas como a velocidade, a duração, o ritmo, além de suas qualidades espetaculares e ambientalizadoras, de sua semiótica cosmológica, religiosa e de conotação espiritual. De acordo com o autor, esse fenômeno possibilita uma vasta gama de possibilidades estéticas (2007:29). Portanto, tal como o movimento Barroco procura paradigmas que caracterizem as texturas das dobras que permeiam suas obras de arquitetura, escultura, pintura, música, entre outros, nós também procuramos estabelecer um paradigma para a dobra luminosa na artemídia. Seja na relação entre o interior ou o exterior, ou ainda entre o alto e o baixo, como aponta Deleuze, o Barroco se mostra como um estilo de arte na qual existe uma harmonia entre os contrários, o que se aproxima da noção de fluxo. Ao pensar uma estética do fluxo aplicada às obras de artemídia, propomos pensar numa atualização contemporânea da dobra luminosa da pintura barroca, em que a relação entre claro e escuro se

\footnotetext{
${ }^{89}$ Leibiniz (1646 - 1716) foi um filósofo e matemático alemão. Sua filosofia se voltou principalmente à metafísica e sua principal contribuição refere-se ao conceito de "mônada": uma substância simples, individual e sem partes, onde há uma multiplicidade na unidade; são os elementos das coisas ou os Átomos da Natureza. (Esses princípios foram retirados dos noventa aforismos que constituem a 'Monadologia' de Leibiniz. Disponível em português em:

< http://www.leibnizbrasil.pro.br/leibniz-pdf/monadologia.pdf > . Acessado em 06/09.2014
} 
faz perceber nos limites de transição entre um estado e outro. Nessa atualização, destacamos que, tal como a dobra barroca, a dobra luminosa da estética do fluxo também carrega em si um movimento que, justamente, torna possível a harmonia entre os opostos, ou seja, uma oscilação rítmica e híbrida.

O sujeito, antes observador e agora participador da obra, encontra-se, nessa dinâmica, no interior da dobra. No seminário inititulado Discours de la Méthode Postmoderne, ministrado na Sorbonne em 2013/2014 acerca do método na pós-modernidade, Michel Maffesoli faz a seguinte afirmação, na sessão de 09/12/2013: "estamos na dobra". Concordamos com o sociólogo pois acreditamos que somente assim é possível apreender o fluxo. Ele dialoga com o conceito de trajeto antropológico ${ }^{90}$ de Gilbert Durand, para dar continuidade a seu pensamento dizendo que, no método pós-moderno devemos levar em conta o movimento, bem como as implicações, os gostos e os sentidos do indivíduo, pois assim se constituirá a reflexão epistemológica nesse contexto. Vemos que a questão da percepção e da experiência tornam-se fundamentais para a organização de um pensamento metodológico contemporâneo que acaba por se consolidar sobre um aspecto estético — o qual podemos experimentar nas obras de artemídia.

Dessa maneira, retomando a questão da luminosidade, podemos dizer que a oscilação da luz é uma característica das imagens em perpétua metamorfose. Citando Pasolini, DidiHuberman afirma que esse tipo de imagem tem um caráter indestrutível, invisível, porém latente (2011:62). São imagens de sobrevivência, poética e visualmente falando, às quais o cineasta italiano se referia por meio da metáfora do vaga-lume. Sua observação se voltava principalmente a uma crítica da imagem da grande mídia, pasteurizada, em contraponto à imagem da cultura popular, rica, pouco a pouco apagada pelos espetaculares projetores da cultura midiática mas que, ainda assim, tentava sobreviver. O vaga-lume é o símbolo dessa resistência, cuja luz trêmula se faz perceber também na escuridão. Nas obras de artemídia, a intermitência da luz permite que a imagem se constitua englobando intervalos, brechas desobstruídas para as possibilidades de hibridismo, de diálogo entre linguagens e de diversas interpretações a partir da experiência de um interlocutor — obra aberta. Aí, segundo DidiHuberman pode haver dialética, não no âmbito da luz ofuscante (2011:26).

Bem antes da artemídia, no entanto, podemos encontrar vários artistas que procuraram experimentar com a luz em movimento, principalmente na arte cinética. Eles procuravam compreendê-la como meio, através de uma interação entre arte, ciência e tecnologia. Segundo

\footnotetext{
${ }^{90}$ Para Durand, por trajeto antropológico se compreende "a incessante troca que existe ao nível do imaginário entre as pulsões subjetivas e assimiladoras e as intimações objetivas que emanam do meio cósmico e social.”(DURAND;2002:41)
} 
Frank Popper, "o movimento não supõe necessariamente um móbil, quer dizer, um objeto definido por um conjunto de propriedades determinadas, basta que ele encerre um 'algo que se move', no máximo um 'algo de colorido' ou 'de luminoso', sem cor nem luz efetivas" (2007:369). Vemos, portanto, que o movimento da luz é trabalhado, muitas vezes, por meio da experiência sensorial.

No Brasil podemos destacar a obra de Abraham Palatnik ${ }^{91}$, com seus cinecromáticos $^{92}$, a partir da década de 1950. Sobre uma tela de plástico que cobria os aparelhos, é possível ver o jogo de cores e formas que se movimentam por meio de aparelhos elétricos, numa obra híbrida entre pintura, escultura e cinema. Os cinecromáticos de Palatnik vão ao encontro dos experimentos de Moholy-Nagy que buscavam uma pintura luminosa, sem pigmentos. Tais obras acabam convidando à contemplação de um tempo próprio a elas, que se forma na transição entre os elementos de uma pintura cinética. Conta-se que Joan Miró (1893 - 1983), após conhecer o trabalho de Palatnik na Bienal de Veneza, em 1964, decidiu visitar uma mostra individual do artista, que acontecia no Hochschule Museum de Saint Gallen, na Suíça e lá permaneceu durante muito tempo contemplando as "máquinas de pintar"93.

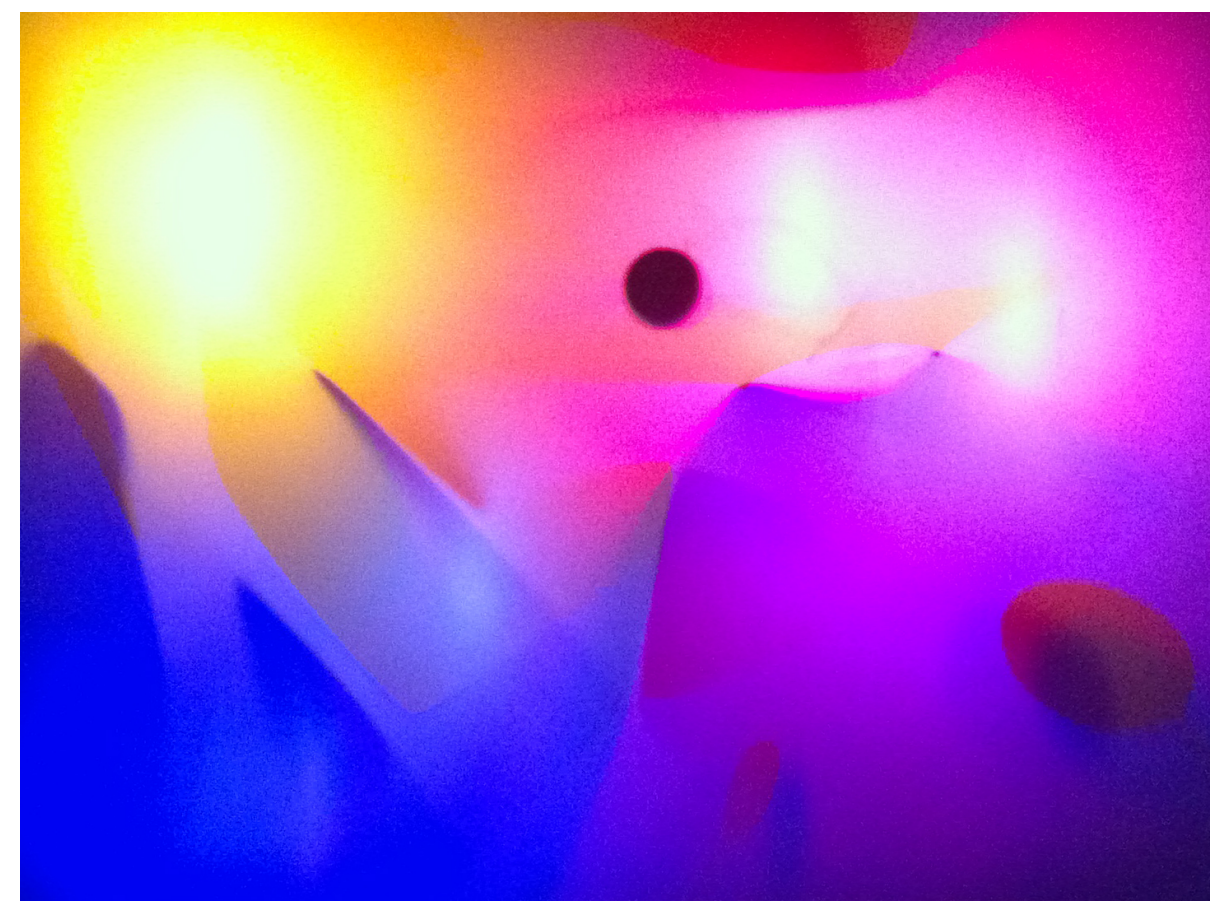

Figura 23: Um frame da imagem de um dos aparelhos cinecromáticos de Palatnik

\footnotetext{
${ }^{91}$ Abraham Palatnik (1928 - ) é um artista plástico brasileiro pioneiro na arte cinética no Brasil. Foi um dos integrantes do Grupo Frente juntamente com outros poetas e artistas concretos e neoconcretos.

${ }^{92}$ Disponível em: < https://www.youtube.com/watch?v=95vTgFEoYyg >. Acessado em 21/02/2014. Vídeo em DVD anexo: pasta 'Capitulo_03' >> 12.Cinecromaticos.mp4

${ }_{93}$ Informação retirada do site Itaú Cultural: <http://www.itaucultural.org.br/tecnica/palatnik/palatnik.htm> Acessado em 20/02/2014
} 
Outro artista que explora a relação luz e movimento é o argentino Julio Le Parc ${ }^{94}$. Ele trabalha com projeções, espelhos, móbiles, materiais transparentes, dentre outros, criando espaços de interação entre o visitante e obra. Um de seus trabalhos, Continuel-Lumière Mobile $(1960)^{95}$ se assemelha a uma cortina de pequenos círculos de aço suspensos por fios de nylon. Dois pequenos projetores iluminam a peça, que reflete luz para todos os ângulos, tomando o espaço da sala escura - notamos a semelhança com o experimento do modulador espaço-temporal de Moholy-Nagy. A obra de Le Parc forma um céu de estrelas onde nos inserimos. Permanecemos com os pés no chão, mas temos a sensação de flutuar. A luz tem essa característica de remeter à leveza bem como de nos fazer senti-la, principalmente quando associada ao movimento.

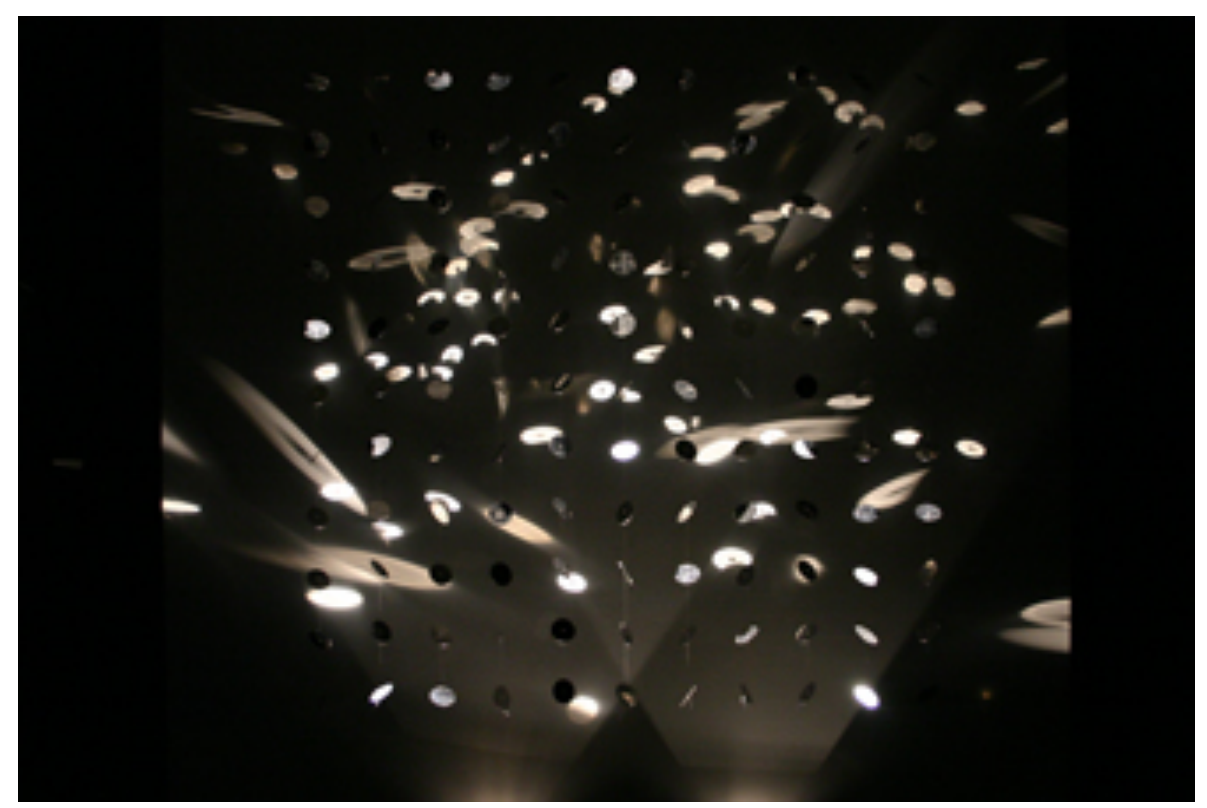

Figura 24: Continuel-Lumière Mobile (1960), Julio Le Parc

Uma manifestação híbrida que se torna possível graças à luz é a holografia. Num holograma, cada parte que o constitui contém a informação do todo. Um pequeno pedaço de um holograma terá informações de toda a imagem do mesmo holograma completo. Segundo Popper, a holografia explora tanto o espaço quanto a ilusão das qualidades estéticas da luz (2007:25). A total visualização da proposta do holograma só se faz possível mediante o movimento. Além disso, a própria obra, com o percurso realizado pelo observador ao seu redor, se transforma, sendo também mutante.

\footnotetext{
${ }^{94}$ Julio Le Parc (1928 - ) é um artista argentino radicado na França que se dedica à op-art e arte cinética. Site do artista: $<$ www.julioleparc.org $>$

${ }^{95}$ Disponível em: < https://www.youtube.com/watch?v=gxedi_yii7s >. Acessado em 21/02/2014. Vídeo em DVD anexo: pasta'Capitulo_03'>> 13.Continuel_Lumiere_Mobile.mp4
} 
O ZKM possui uma coleção de hologramas, dentre os quais me chamou atenção a série de retratos, especialmente a obra Lucy and tin hat (1989), de Patrick Boyd ${ }^{96}$, considerada por muitos críticos a Mona Lisa da holografia. Vemos o retrato de uma mulher que nos olha fixamente. Ao nos deslocarmos horizontalmente ao redor do quadro, observamos os dois lados do seu rosto e seus olhos acompanham nosso percurso. Se nos deslocarmos verticalmente, a figura do rosto lentamente se abaixa, mostrando-nos o chapéu sobre sua cabeça, nos dando a sensação de estarmos acima da imagem. Essas imagens que se movimentam e saltam da tela, coloridas artificialmente, parecem projeções fantasmagóricas de espectros humanos aprisionados. A luz aí, associada ao movimento, é essencial para nos fazer ver a imagem em todas as suas nuances tridimensionais a partir de um suporte bidimensional, levando-nos a questionar não apenas a noção de espaço bem como o que é real e o que é virtual - outra importante relação híbrida que se sustenta na oscilação entre contrários e que se faz presente nas obras de artemídia, como veremos a seguir.

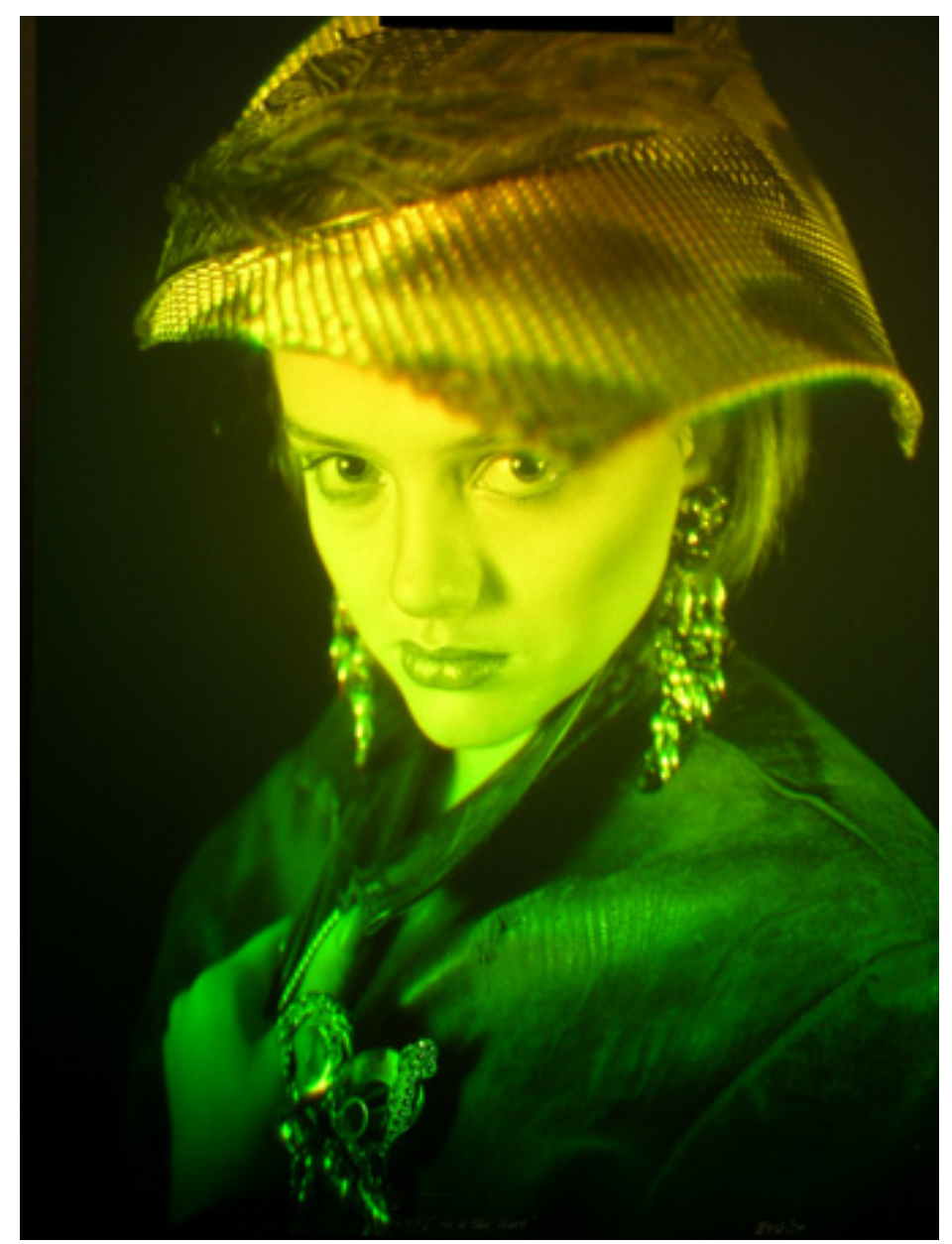

Figura 25: Lucy and tin hat (1989), Patrick Boyd

\footnotetext{
${ }^{96}$ Patrick Boyd $(1960$ - ). Site do artista: http://www.patrickboyd.co.uk/
} 


\subsection{Entre as sensações de real e virtual: imagens-cristal no jogo entre espaço e tempo}

A própria natureza das imagens impalpáveis da artemídia coloca em questão a relação entre o real e o virtual. Esta é, sem dúvida, uma discussão que se torna cada vez mais necessária na sociedade em que vivemos, diante da crescente informatização de dados. Assim como o período moderno representou a época do produto, derivado dos processos de fabricação em massa dentro de um contexto pós-revolução industrial, na contemporaneidade somos surpreendidos por informações que percorrem redes invisíveis, gerando relações impalpáveis com as quais lidamos cotidianamente. Nos habituamos a uma relação com o virtual que se estende a tal ponto em que passaremos a não mais distinguir entre o que se apresenta como real e o que se apresenta como virtual. Em realidade, se por enquanto ainda fazemos essa separação, a título classificatório ou como forma de compreendermos melhor nossa posição no mundo, cada vez mais essa atitude não fará sentido, pois a própria ontologia humana se constituirá de forma híbrida, como dissemos anteriormente.

De acordo com Philippe Quéau, a linguagem do virtual, relacionada ao computador, constitui o surgimento de uma nova escrita imersiva e interativa que emerge das comunidades virtuais, sendo urgente compreender sua gramática e estilo. Ele alerta ainda para o grande risco de confusão que se fará entre as categorias do real e as categorias do virtual (1993:118 apud VENTURELLI, 2011:98). Dessa forma, antes de prosseguirmos, faz-se necessário um esclarecimento sobre a relação entre real e virtual.

Pierre Lèvy afirma que a noção que se opõe ao virtual é a de atual, não a de real, pois o real se oporia à noção de possível — como também acredita Deleuze. O virtual "seria como uma situação subjetiva, uma configuração dinâmica de tendências, de forças, de finalidades e de coerções que uma atualização resolve (LÈVY;1996:137). Ainda sobre o virtual, Deleuze recorre aos dizeres de Proust sobre os estados de ressonância: "reais sem serem atuais, ideais sem serem abstratos" e complementa: "simbólicos sem serem fictícios." (1991:199). Para o autor, o virtual deve ser definido como parte do objeto real - "como se o objeto tivesse uma de suas partes no virtual e aí mergulhasse como numa dimensão objetiva." (Ibidem:199)

A atualização pode ser compreendida como um ato de criação. O virtual existe sempre, de forma latente, e ele acontece mediante uma atualização. Já a relação entre o possível e o real se dá por uma insistência daquilo que é possível e que se manifesta no real, aí persistindo. Segundo Lèvy, a realização encarna uma temporalidade linear, mecânica e determinista, enquanto a temporalização da atualização estaria ligada ao movimento (1996:138-139). A relação realização-potencialização seria da ordem da seleção. Pierre Lèvy opõe a ela o 
parâmetro da criação, ao qual pertencem a atualização e a virtualização. A atualização inventa uma forma, cria informação nova (1996:139).

Diante desse esclarecimento, optamos abordar esse assunto por meio da sensação que apreendemos dele, visto que nos voltamos, ao longo de toda pesquisa, à percepção por meio dos sentidos. E escolhemos opor a "sensação de real" ao virtual. Acatamos a noção de "sensação de real" como uma atualização, não como real, tal como define Pierre Lèvy. Neste caso, prevalece o senso comum, pois assumimos a utilização dos sentidos como método epistemológico próprio à contemporaneidade. Em uma seção do seminário Discours de la Méthode Postmoderne ministrado em 03/02/2014 na Sorbonne, Michel Maffesoli fala sobre o princípio da diversidade como um dos pilares do método pós-moderno. Segundo ele, partindo dessa ideia, o exterior cria o ser e fertiliza a inteligência e, assim, os sentidos assumem papel preponderante nesse processo, fomentando o senso comum. Portanto, não nos espantamos com a possibilidade de por vezes nos depararmos com a palavra "real" em oposição ao "virtual", usadas sem maiores critérios. Mesmo assim, preferimos fazer uma distinção conceitual acerca de cada palavra e de seus usos antes de prosseguir.

No contexto desta pesquisa ainda acrescentamos à "sensação de real", apresentada como uma dinâmica de atualização nas obras de artemídia, o aspecto da imaterialidade, que se manifesta principalmente na relação do participador com as imagens que as compõem. Dessa forma, a "sensação de real" que usamos aqui, além de se consitituir como uma solução a um problema virtual, ainda carrega, em si, a ligação com a experiência entre corpo e imagens impalpáveis - muitas das quais constituídas pela luz de projetores, por sua vez matéria confundida com o imaterial devido a seu aspecto impalpável.

Em À sombra $(2011)^{97}$, de Katia Maciel $^{98}$, essa sensação é criada por meio de uma videoinstalação imersiva constituída de projeções de vídeo que recriam um ambiente em que três paredes são tomadas por imagens de uma paisagem do Jardim Botânico do Rio de Janeiro. O piso é tomado por imagens de areia e folhas secas e o som é formado por uma edição do ruído de folhas secas. Há um banco próximo à parede do fundo, que chama à interação. Sensores de presença registram a aproximação do espectador. Ao sentar-se, uma imagem de sombra da árvore que se encontra atrás do banco, cobre o interator e ali permanece enquanto aquele estiver sentado. Ao levantar-se e ir embora a sombra começa a regredir,

\footnotetext{
${ }^{97}$ Disponível em: < http://vimeo.com/63162773 > . Acessado em 26/02/2014. Vídeo em DVD anexo: pasta“'Capitulo_03'>> 14. A_sombra.mp4

${ }^{98}$ Katia Maciel é artista, cineasta, poeta, professora da UFRJ e pesquisadora do CNPq. Site da artista: www.katiamaciel.net
} 
acompanhando o movimento do participador, ambos desaparecendo em direções opostas. A paisagem escolhida do Jardim não foi a tradicional alameda das palmeiras imperiais, símbolo do lugar. Kátia Maciel escolheu um canto ordinário, não conhecido do grande público e convidou seu espectador a sentar-se no banco que compõe a instalação como se estivesse se sentando em um banco do próprio Jardim. É um convite à contemplação de um outro lugar que faz parte do Jardim Botânico mas não do imaginário que se faz dele. A obra procura, a partir da estrutura instalativa e da imagem em movimento e interativa, aliada ao som, criar uma experiência híbrida não apenas de recursos multimídia e diferentes linguagens, mas também um híbrido entre a sensação de real e o virtual.

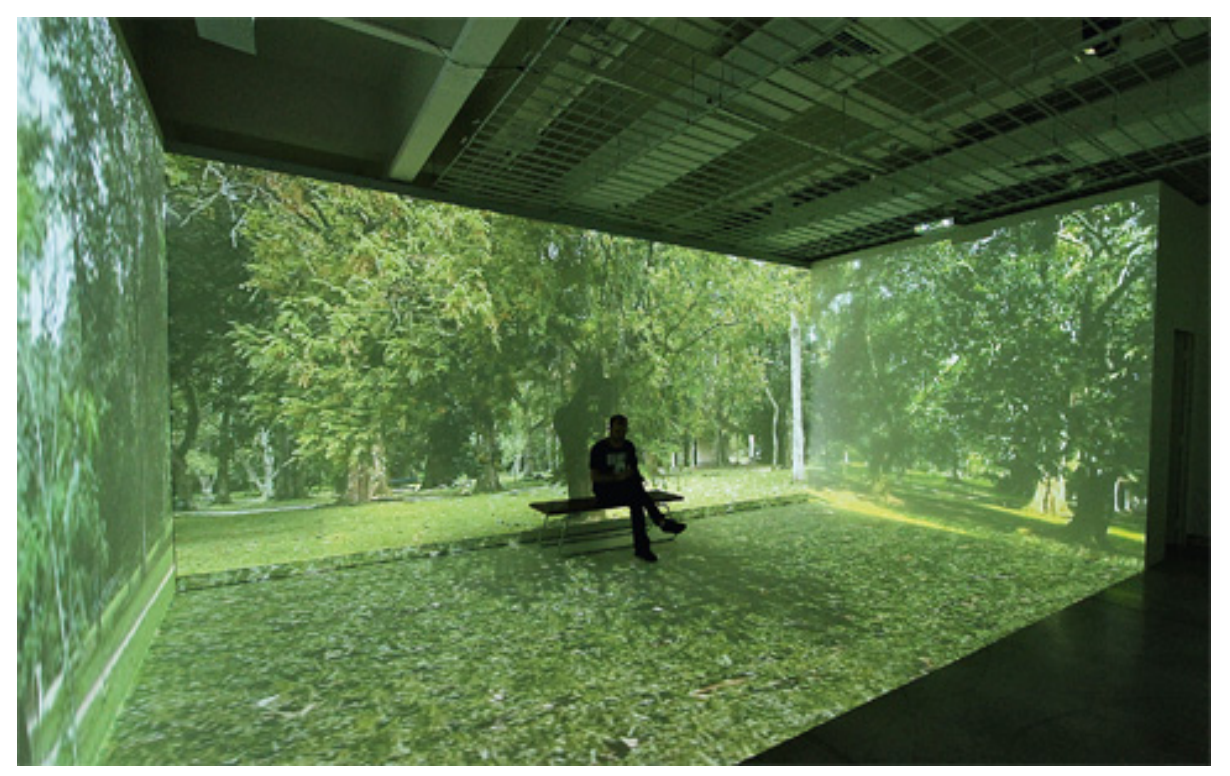

Figura 26: À sombra (2011), Katia Maciel

A artista experimenta o mesmo conceito em outra obra intitulada Arvorar (2012) ${ }^{99}$, parte da exposição Dois, realizada em conjunto com André Parente ${ }^{100}$ em dezembro de 2012 no Espaço Caixa Cultural em Brasília. Nessa instalação interativa encontramos uma projeção de grande dimensão mostrando a imagem de uma floresta. Em frente à projeção encontram-se microfones suspensos. O participador é convidado a se aproximar dos microfones e assoprar. Ao fazê-lo, as folhas das árvores da projeção se movem, como se o sopro do interator fosse o causador do movimento. Ambas as obras criam uma zona de indiscernibilidade entre real e virtual. Transitamos poeticamente nesse ambiente híbrido num fluxo contínuo em que essa relação não apenas se torna natural, mas também muda nossa percepção de espaço.

\footnotetext{
${ }^{99}$ Disponível em: < http://vimeo.com/64363159 >. Acessado em 26/02/2014. Vídeo em DVD anexo: pasta ‘Capitulo_03 >> 15.Arvorar.mp4

${ }^{100}$ André parente é artista, cineasta, professor da UFRJ e pesquisador do CNPq. Site do artista: www.eco.ufrj.br/aparente/
} 


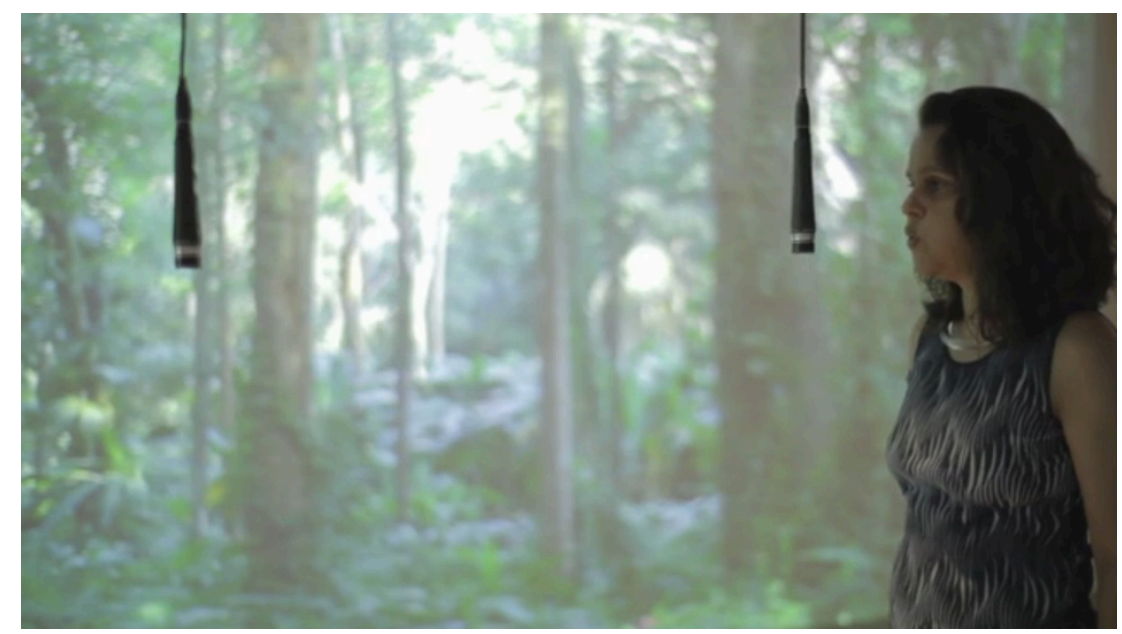

Figura 27: A artista interagindo com a obra Arvorar (2012)

Dessa forma, podemos retomar o pensamento de Pierre Lèvy ao afirmar que a virtualização se apresenta ainda como o movimento mesmo do "devir outro", colocando em jogo processos de criação (1996:11). Essa noção também é desenvolvida por Deleuze, ao relacioná-la ao eterno retorno nietzschiano: "retornar é o ser do devir." (1991:50). Para tanto, ele aborda a relação entre a diferença e a repetição, que possibilita o eterno retorno, pois o que retorna é sempre o mesmo, porém diferente - característica percebida devido exatamente a sua repetição. Deleuze se utiliza da metáfora do círculo para discorrer acerca dessa dinâmica, situando o Mesmo na circunferência, e a Diferença no centro do círculo, decentrado a cada instante, girando apenas em torno do desigual (1991:63). É a repetição, portanto, que torna a diferença perceptível:

Com o eterno retorno, Nietzsche não queria dizer outra coisa. O eterno retorno não pode significar o retorno do idêntico, pois ele supõe, ao contrário, um mundo (o da vontade de potência) em que todas as identidades prévias são abolidas e dissolvidas. [...] O eterno retorno não faz "o mesmo" retornar, mas o retornar constitui o único Mesmo do que devém. (DELEUZE; 1991:50).

Deleuze dá prosseguimento à reflexão, a partir de Nietzsche, ao dizer que apenas as formas extremas retornam, aquelas que se desenrolam no limite e vão até o extremo da potência, transformando-se, passando umas nas outras: "Só retorna o que é extremo, excessivo, o que passa no outro e se torna idêntico" (Ibidem:50). Se retomarmos a ideia deleuziana de "devir todo mundo" (ou devir-imperceptível) sobre a qual já falamos no primeiro capítulo, podemos compreender o eterno retorno como uma expressão do ser comum de todas as metamorfoses ou de tudo o que é extremo, “[...] de todos os graus de potência na 
medida em que são realizados" (Ibidem:50), assim como acontece com o processo de virtualização: atualizações de possibilidades.

Os estados extremos dos quais fala Nietzsche também se aproximam do transe deleuziano, ao discorrer sobre o devir. O filósofo alemão relaciona esse estado ao conceito de hybris, que para os gregos tem uma conotação ligada ao orgulho, à arrogância, à perda de controle, levando quem a pratica à ruína. É um estado de caos, loucura e paixão que chega a ser subversivo. No entanto, segundo Nietzsche, é na hybris que cada um encontra o ser que o faz retornar. A hybris é, portanto, uma experiência na qual nos encontramos ligados ao todoum heraclitiano (no logos ou na coletividade originária), ou encontramos o devir todo mundo do qual fala Deleuze; na qual experimentamos o fluxo. Somos transformados pela experiência e ela se soma ao nosso ser. Somos os mesmos, porém, diferentes, tal qual o homem que adentra o rio pela segunda vez em Heráclito. A transformação se dá por adição, não por substituição ou subtração, ela não rejeita o estado anterior, daí podermos falar em repetição e diferença. Almejamos estados que permanecem em potência daquilo que podemos ser. Esses estados são alcançados mediante e experiência da hybris e, depois, retornamos ao estado anterior, mas transformados.

Essa é a força própria à vontade de potência, que se constitui num impulso similar ao que existe na dinâmica de atualização e virtualização. Nietzsche destaca o caráter de superação e de busca pelos contrários presente na vontade de potência. No caso da atualização temos um acontecimento, segundo Lèvy, em que se efetua um ato que não estava pré-definido e que modifica a configuração dinâmica na qual ele adquire uma significação: "A articulação do virtual e do atual anima a própria dialética do acontecimento, do processo, do ser como criação." (1996:137). A operação dialética, segundo o autor, funda o virtual porque abre, sempre de uma forma diferente, um segundo mundo que nasce e renasce sem cessar, num processo infinito de desdobramento, tal como se dá na experiência subjetiva do observador convidado a participar da obra de artemídia.

Uma obra que busca explorar estes estados de transe é Circuladô $(2007)^{101}$, de André Parente. A videoinstalação interativa em preto e branco busca criar no espectador a sensação de estar no centro de um zootrópio gigante, de seis metros de altura por 18 de comprimento. As imagens que constituem a obra mostram personagens que giram sem parar, num transe provocado pela vivência de situações limite. O espectador pode controlar a velocidade e

\footnotetext{
${ }^{101}$ Disponíveis em: < https://www.youtube.com/watch?v=TxDZdeB153c $>$ e $<$ https://www.youtube.com/watch?v=4xW1pGywx-I >. Acessados em 26/02/2014. Vídeo em DVD anexo: pasta 'Capitulo_03 >> 16.Circulado.mp4 | 16a.Circulado.mp4
} 
deslocamento desses personagens - e consequentemente do giro que advém do transe manipulando um giroscópio disposto no centro da sala. Ao dirigir o movimento, o observador se coloca também como protagonista que vivencia essas sensações, junto a cada um dos personagens em questão, controlando, também, a intensidade de sua experiência individual da obra.

É importante observar como esse movimento de rotação está relacionado às situações vividas pelos personagens escolhidos pelo artista que, por sua vez, se aproximam bastante de algumas das noções de fluxo que levantamos anteriormente. Desde o Édipo de Pasolini que, em meio ao desespero e à dúvida, rodopia, procurando um caminho que o afastasse de seu trágico destino, a Thelonious Monk, tomado por um devir que o leva a ser-um-com sua própria música, em suas performances de improvisação; também o Corisco de Glauber Rocha, em seu derradeiro movimento em vida, gira, enfrentando a morte, ou ainda um dervish turco, frades franciscanos e uma pomba gira, que rodopiam em busca da experiência do transe espiritual. A proposta do artista, nessa obra, joga com a questão da virtualidade não no sentido da imagem virtual, mas dos estados de percepção e consciência que se configuram a partir das imagens reais em diálogo com as imagens e sensações despertadas pela mente, no decorrer da experiência da obra. A própria disposição em círculo da instalação já nos coloca imersos em um circuito não-linear que se completa na experiência de cada participador.

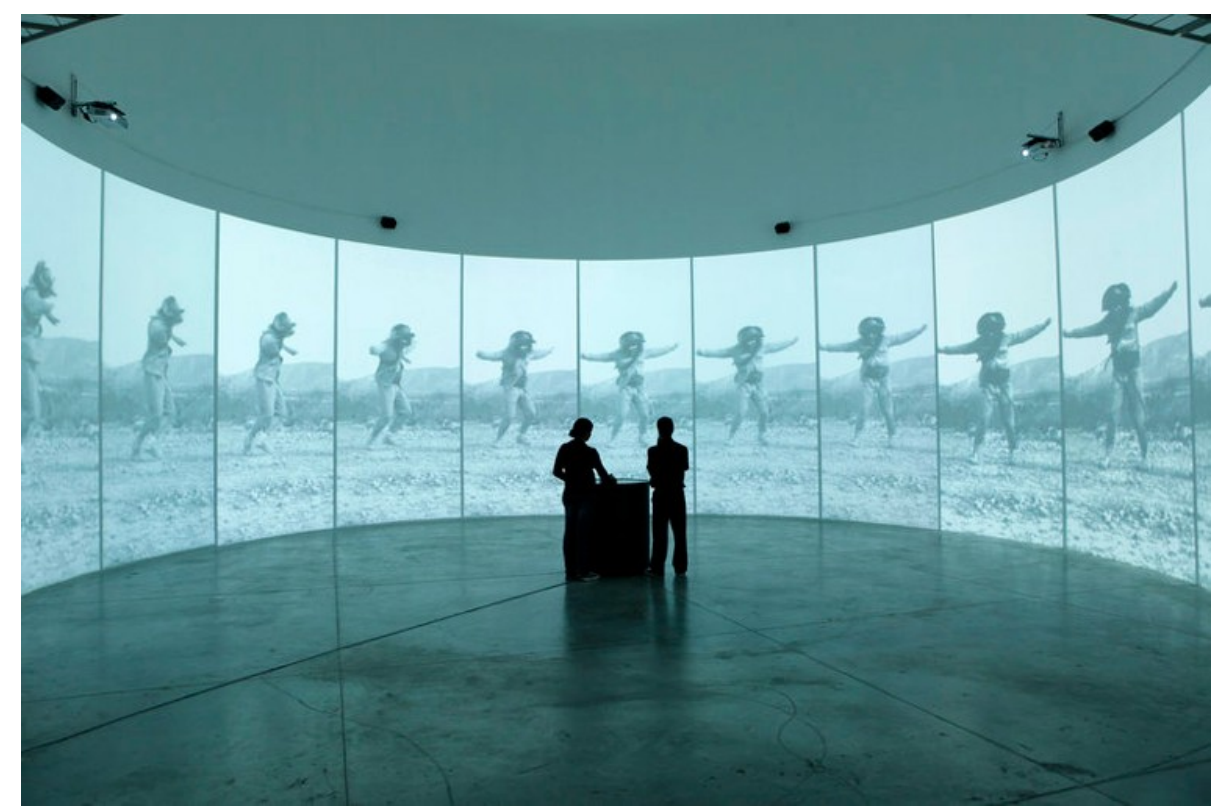

Figura 28: Circuladô (2007), André Parente 
O virtual pode se configurar como uma possibilidade de experimentar sensações extremas em que podemos vivenciar o eterno retorno, pois os sistemas de realidade virtual transmitem uma quase presença, como ressalta Lèvy (1996:29), em que o corpo se multiplica. A repetição aí entra em cena: "nada muda no objeto que se repete, mas muda alguma coisa no espírito que a contempla.” (DELEUZE;1991:76). Suzete Venturelli acredita que o virtual está transformando totalmente a representação que temos do mundo, pois ele tem como característica eliminar tanto a realidade quanto a imagem que fazemos dela (2011:78). As noções de espaço e tempo também se transformam, pois num ambiente computacional o tempo se torna no tempo da experiência e da duração. Ele é reversível, sem presente, passado e futuro, podendo recomeçar a qualquer momento, "de alguma maneira, seria o não-tempo." (VENTURELLI, 2011:100). O espaço, por sua vez, é o do estar-junto, não importa onde estejamos de fato. O não-tempo e o não-espaço, segundo a autora, fazem surgir um tipo de sentir totalmente inédito em que o sentido completo de aisthesis é empregado sem subterfúgios teóricos. Para Venturelli, a busca da fusão entre virtual e atual na arte hoje representa o que no passado significou a fusão da arte com o cotidiano (2011:160).

A experiência estética (aisthesis) contemporânea se dá tanto no mundo atual quanto no virtual. Na verdade, ela se constrói entre os dois mundos, no intervalo entre real e virtual, único lugar onde talvez possamos captar o sentido de todas essas transformações. A oscilação entre os dois estados é visualizada por Deleuze através das imagens cristal, nas quais ocorre uma interpenetração permanente de imagens atuais e virtuais, tornando-se, finalmente, indiscerníveis. Aí temos um terreno fértil para as imagens fantasma de Warburg que remontam justamente a essa "hesitação fundamental entre a clara estrutura do atual e os traços obscuros deixados pelo não-presente." (SIEREK, 2009:138).

Em Ballet Digitallique $(2010)^{102}$, de Lali Krotoszynski ${ }^{103}$, por exemplo, vivenciamos uma experiência de contato com imagens desse gênero. $O$ participador tem, num primeiro momento, a forma de seu corpo capturada por um scanner que transforma esse corpo em uma silhueta eletrônica. Depois, essa silhueta aparece em uma tela de grandes proporções, na qual ganha autonomia, desenvolvendo movimentos próprios, como se estivesse a dançar, junto às silhuetas de outros participantes que já passaram por ali. Dessa forma, podemos visualizar o mundo de fantasmas do qual fala Warburg, em que várias silhuetas interagem entre si nessa dimensão virtual.

\footnotetext{
102 Disponível em: < https://www.youtube.com/watch?v=bXL0FRvwSCA >. Acessado em 26/02/2014. Vídeo em DVD anexo: pasta'Capitulo_03'>>17.Ballet_Digitallique.mp4

${ }^{103}$ Site da artista multimídia: < http://lalikrotoszynski.net/ >
} 
Um dos fatos mais interessantes é que, ao nos colocarmos diante da grande tela que nos apresenta esse outro universo, procurando a silhueta eletrônica de nós mesmos, também nosso corpo, ao se posicionar entre o projetor e a tela, passa a integrar esse mundo naquele momento, com a sombra que é projetada. Integramos os dois mundos, o real e o virtual, concomitantemente. E nos reconhecemos, nessa interação, enquanto corpo, sombra e silhueta. Podemos dançar com nós mesmos ao movimentar nosso corpo que controla a sombra que, por sua vez, dialoga com a silhueta já em movimento. Real e virtual se mesclam e formam a percepção de um universo conjunto - devir, ou fluxo.

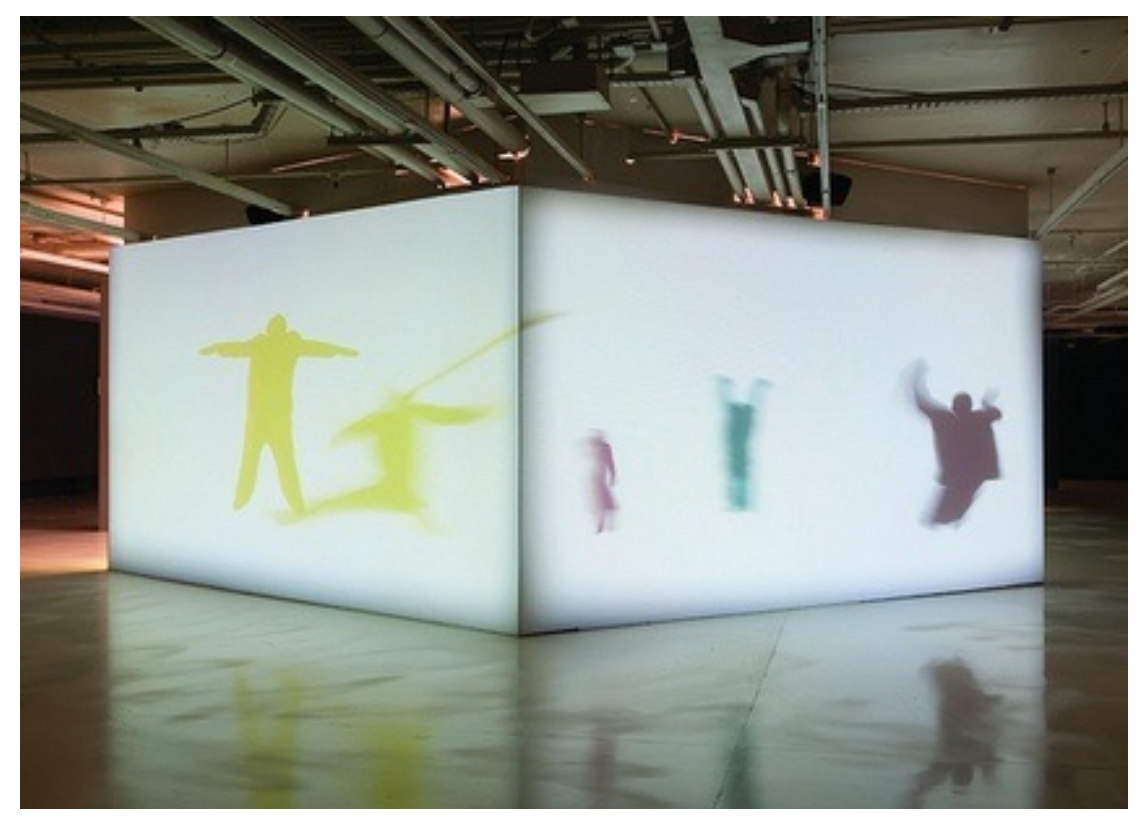

Figura 29: Ballet Digitallique (2010), Lali Krotoszynski

Se pensarmos ainda na natureza digital da imagem virtual podemos, também a partir do pensamento de Warburg, compreendê-la por uma relação com a metáfora da constelação, pois essas imagens se formam a partir de um sistema de pixels que se ligam e se alternam, de acordo com a configuração desejada. Temos aqui uma imagem virtual digital como manifestação energética - no sentido warburguiano - que promove a dissolução dos paradigmas de representação espacial rígidos vigentes até então. A imagem aí não se interpõe mais entre sujeito e objeto, promovendo sua relação. É mais que isso. Ela se constitui no próprio espaço da relação e a define. $\mathrm{O}$ sujeito penetra a imagem, saindo da posição de "diante da imagem", como afirma Flusser ao se referir às imagens técnicas, pois o próprio objeto se funde ao sujeito e, assim, surgem entidades híbridas meio objeto, meio sujeito, meio imagem, que se relacionam sem hierarquias interpostas. E nas passagens entre elas, instaurase uma outra relação espaço-temporal, caracterizada pelo aspecto imaterial dessas imagens. É 
nesse cenário que Edmond Couchot acredita surgir o sujet-on e que nós devemos considerar as relações entre obra, autor e espectador como contíguas e oscilantes (1998:253).

Tal sensação se manifesta de forma cinética e sinestésica na obra Standing Wave $(2013)^{104}$, de Annica Cuppetelli e Cristobal Mendoza ${ }^{105}$. Exposta pela primeira vez no Festival Némo de 2013, no Espace Centquatre em Paris, onde a visitei em dezembro de 2013, a obra se constitui por uma tela em relevo, ondulada, de grande dimensão e coberta por uma espuma que absorve o som. Ela é iluminada por uma projeção de vídeo de linhas luminosas geradas por computador que reagem aos movimentos do participante. Esses movimentos também controlam um sistema de síntese sonora em tempo real, calibrado para espelhar e complementar a projeção interativa. Ao adentrar a sala escura da instalação, vemos a tela com as linhas que vibram - tais como cordas de um instrumento - e a sensação de imersão é alcançada, neste momento, pelo alto volume do som ambiente, que parece refletir a sensação de vibração das linhas luminosas. Nessa obra a experiência se manifesta de forma muito evidente na dimensão da percepção e da sensação. Ao começarmos a nos mover em frente a tela, vemos que as linhas acompanham nosso movimento. No entanto, destacamos que esse deslocamento da imagem é feito de forma fluida e orgânica. Essa característica é importante para o efeito de nos sentirmos ligados à linha, de fazermos parte do movimento junto com ela, de forma que, ao vê-la vibrar, também experimentamos uma vibração acompanhada de uma sensação de leveza, como se nosso corpo fosse tomado pela ondulação das linhas. Somos levados a realizar movimentos cada vez mais soltos, despretensiosos, como se quiséssemos flutuar e intensificar a sensação experimentada e reforçada pela simbiose com as cordas oscilantes. Um comportamento que podemos perceber tanto sobre o próprio corpo como também na observação do comportamento dos demais participantes que estavam na sala um deles, inclusive, chegando a executar um movimento similar ao bater de asas de um pássaro, como se quisesse voar.

O som também reage aos movimentos tanto do participante quanto das linhas luminosas, o que intensifica ainda mais a experiência. Junto aos demais participantes da obra presentes no momento, vivenciamos a sensação de nos transformarmos em luz, som e movimento. Uma experiência de "devir todo mundo", fluida e energética, em que o virtual toma uma dimensão mais real que o real, alterando a própria noção de percepção. Saí transformada pela experiência - aisthesis. O próprio resgate da memória da vivência - exercício que faço

\footnotetext{
${ }^{104}$ Vídeo em DVD anexo: pasta 'Capitulo_03' >> 18.StandingWave.mp4

${ }^{105}$ Annica Cuppetelli (USA) e Cristobal Mendoza (Venezuela) trabalham em parceria desde 2010. Site dos artistas:

$<$ http://cuppetellimendoza.com/ >
} 
agora - me remete novamente à sensação de estar fora do corpo, de ser levada pela flutuação das cordas.

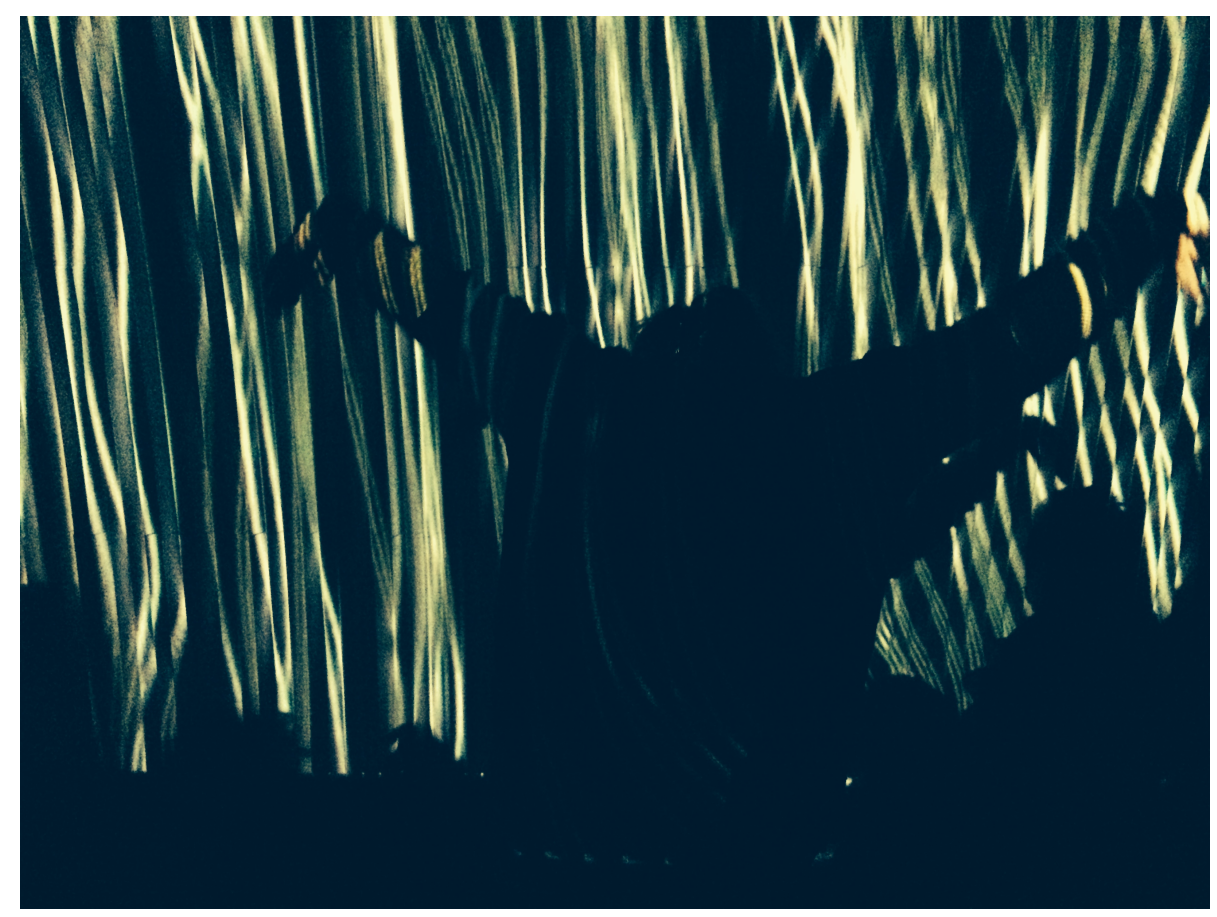

Figura 30: Participador da obra Standing Wave (2013) que simula o bater de asas de um pássaro, junto às cordas virtuais

As brasileiras Rejane Cantoni ${ }^{106}$ e Daniela Kutschat ${ }^{107}$ criaram anos antes uma obra similar, OP_ERA: Sonic Dimension (2005) ${ }^{108}$, que hoje faz parte do acervo do ZKM, na Alemanha. A instalação se constitui como uma ferramenta musical em forma de cubo, em grandes dimensões, onde podemos entrar. Suas paredes são preenchidas por projeções de fios luminosos que também lembram cordas de um instrumento. Cada corda virtual vibra de acordo com a presença e o som emitidos pelos espectadores, captados por sensores que fazem parte da obra. A interação também se dá ao tocar as cordas, que vibram visualmente e emitem sons. A disposição em forma de cubo, como uma caverna, convida o observador a adentrar a obra, imergindo nela. Os sensores de som e movimento permitem que a participação do espectador seja registrada pela linguagem sonora e visual, gerando não apenas um híbrido entre duas linguagens, mas, também, um híbrido com o próprio espectador. Podemos, dessa forma, ver o som e ouvir a imagem resultante da interação. Apesar de não ter presenciado uma exposição da obra, acredito que a grande diferença entre essa produção e a que

\footnotetext{
${ }^{106}$ Rejane Cantoni é artista multimídia, professora e pesquisadora da PCU-SP. Site (em parceria com Leonardo Crescenti): $<$ http://www.cantoni-crescenti.com.br/ >

${ }^{107}$ Daniela Kutschat é artista, professora e pesquisadora da USP. Site da artista: http://danielakutschat.com/blog/

${ }^{108}$ Disponível em: < https://www.youtube.com/watch?v=UzSYdfNYD0U>. Acessado em 26/02/2014. Vídeo em DVD anexo: pasta 'Capitulo_03' >> 19.Op_ERA-Sonic Dimension.mp4
} 
analisamos anteriormente esteja no detalhe do tipo de vibração das cordas, mais orgânico no caso de Standing Wave, que nos faz experimentar a sensação de sermos-um com a obra e os demais participantes, todos transformando-se em informação leve, sonora e luminosa.

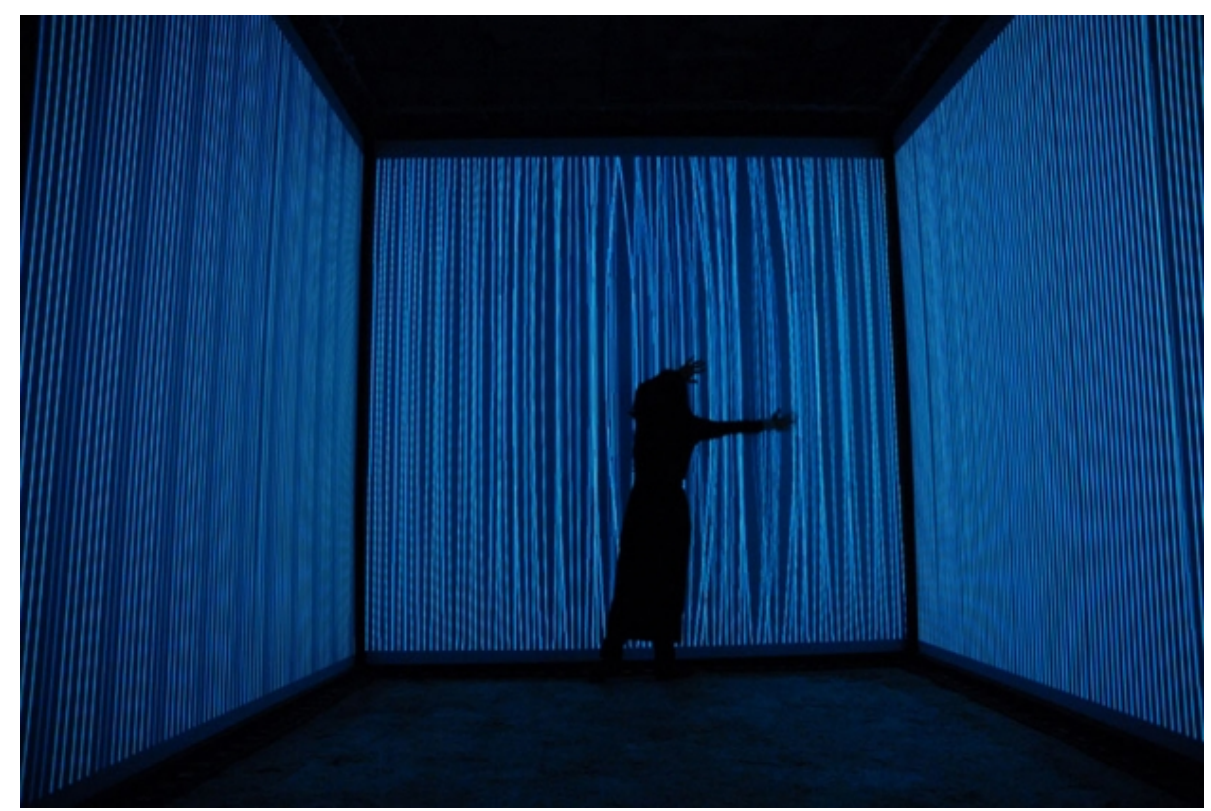

Figura 31: Participador interagindo com a obra $O_{-}$ERA: Sonic Dimension (2005)

Para além da oposição entre real e virtual, Suzete Venturelli traz o pensamento de Debray segundo o qual a imagem graficamente computadorizada passa a ser, de agora em diante, o referente para o real. Assim, toda relação ontológica que, segundo o autor, desde os gregos desvalorizava o diálogo com as aparências foi, agora, invertida.

Uma entidade virtual é efetivamente percebida (e, eventualmente, manipulada) por um sujeito, mas sem realidade física correspondente. Devidamente equipado por sensores e captores de posição, meu corpo pode movimentar-se em um espaço perfeitamente imaterial, animado por uma simulação computadorizada e, em troca, fazê-lo movimentar-se. O paradoxo é que Imagem e Realidade, então, tornam-se indiscerníveis: um tal espaço é explorável e impalpável, ao mesmo tempo, não ilusório e irreal (DEBRAY, apud VENTURELLI, 2011: 159)

A arte se apropria dessa realidade mista criando espaços de imersão. Para Olvier Grau (2003:13), tanto nos casos da arte contemporânea quanto nos panoramas imersivos do século XIX, a maior parte dos casos de imersão se constitui num processo mentalmente absorvente, promovendo passagens entre diferentes estados mentais, devido à diminuição do distanciamento crítico ao que é mostrado e ao crescente envolvimento com o que está acontecendo diante dos olhos. 
Essa também é a essência da realidade de videogames que se utilizam da câmera subjetiva e do aprimoramento dos recursos gráficos dos atuais softwares de 3D para criar ambientes que simulam o real, provocando a sensação de imersão. Ao observar uma cena do jogo Assassin's Creed 2 (Ubisoft, 2009), o realismo dos detalhes mostrados da cidade de Florença, principalmente da basílica Santa Maria del Fiore, é impressionante. Mesmo tendo estado na cidade algumas vezes, apenas na experiência do jogo de videogame foi possível experimentar a sensação de estar na basílica como presencialmente nunca havia experimentado. O jogo permite que o personagem escale a cúpula do Duomo, para além da parte aberta a turistas, permitindo uma vista da cidade de cima da cruz, no ponto realmente mais alto da construção. É possível, ainda, pendurar-se nos lustres de dentro da igreja, tendo uma visão, desde o alto, dos mosaicos desenhados no chão. Podemos nos aproximar também dos detalhes dos vitrais e dos afrescos da cúpula interna. Experiências que o mundo real não nos permite vivenciar. Sejam gráficos extremamente fiéis à realidade visível in loco ou não, a sensação de imersão nos transporta diretamente para Florença, enquanto permanece-se sentado no sofá da própria casa. Interessante também foi observar a reação de pessoas que já haviam jogado o game antes de conhecerem a basílica e depois presenciar sua admiração com a semelhança entre jogo e realidade, frente o encontro com o cenário real de suas aventuras.

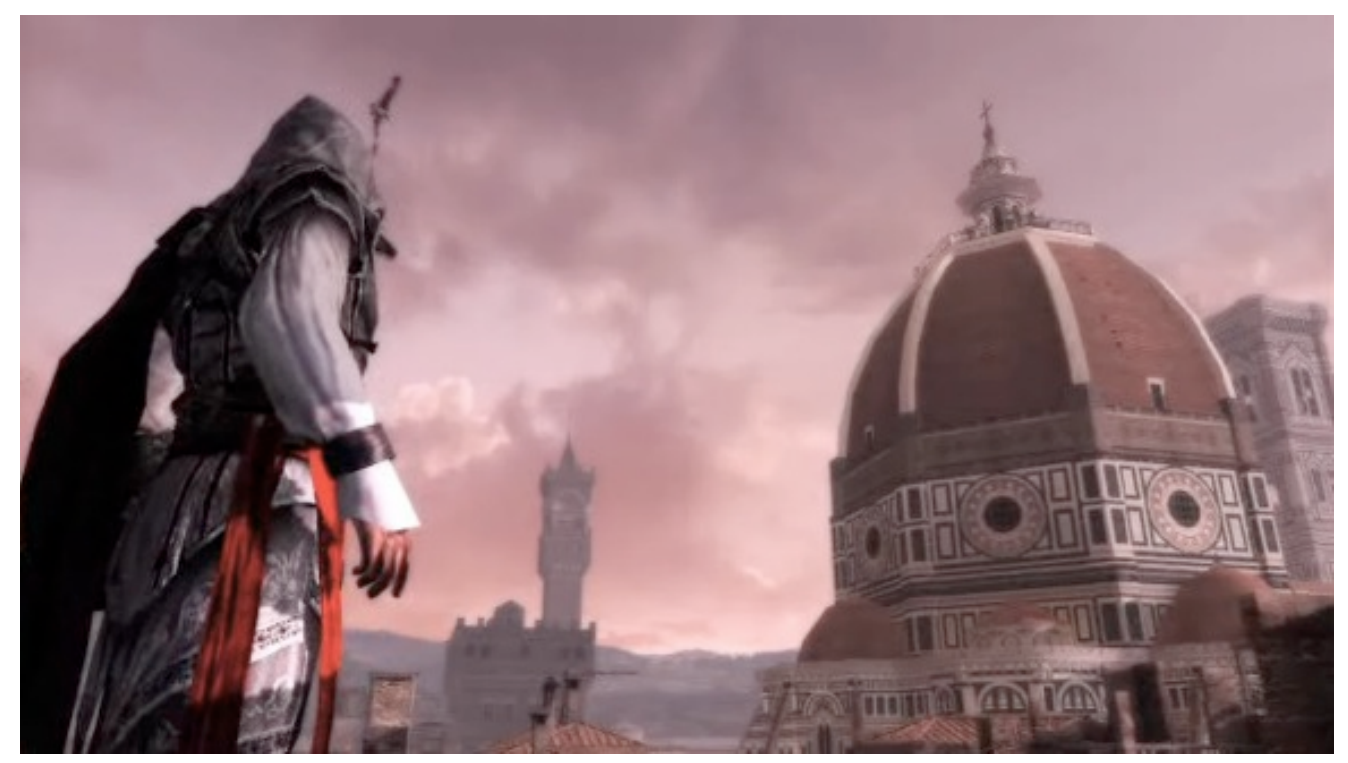

Figura 32: Cena do jogo Assassin's Creed (2009)

Em seus seminários sobre o método pós-moderno ministrados em 2013/2014, Michel Maffesoli aborda a questão de que, na contemporaneidade, a sensação de completude é uma variável que faz mais sentido que a busca pela perfeição. Não importa se as imagens do jogo 
são cópias exatas dos detalhes de Santa Maria del Fiore mas, sim, que a forma como se apresentam no videogame tragam a sensação completa de imersão e sejam capazes de nos transportarem para lá, num processo de desterritorialização que também é característico de nosso tempo. Dá-se aí, a construção de um outro espaço, que se estabelece na oscilação entre real e virtual, um virtual não apenas constituído pelas imagens gráficas e digitais de um computador ou outro dispositivo, mas também das imagens mentais, tão impalpáveis quanto as outras, mas capazes de promover o mesmo transporte. No caso de Assassin's Creed, minha experiência de percorrer a basílica no jogo certamente se completou mediante o diálogo com as imagens e vivências que já havia tido do lugar, criando uma dimensão espacial própria e subjetiva.

Merleau-Ponty aborda uma experiência semelhante ao falar sobre a sensação de habitar a imagem refletida de um quarto. Ele parte da ideia de um sujeito que observa o ambiente onde se encontra por um espelho inclinado $45^{\circ}$ em relação à vertical, que reflete o espaço. Num primeiro momento existe o estranhamento, no entanto, ao desviar o olhar do espelho e voltar a olhá-lo, esse mesmo sujeito se encontra frente uma imagem na qual pode viver.

Esse corpo virtual desloca o corpo real a tal ponto, que o sujeito não se sente mais no mundo em que efetivamente está, e que, em lugar de sentir suas pernas e seus braços verdadeiros, ele sente as pernas e os braços que precisaria ter para caminhar e para agir no quadro refletido, ele habita o espetáculo. É agora que o nível espacial oscila e se estabelece em sua nova posição. Portanto, ele é uma certa posse do mundo por meu corpo, um certo poder de meu corpo sobre o mundo (2011:337)

$\mathrm{O}$ campo perceptivo, nesse segundo momento, se ajusta à nova realidade permitindo o transporte para dentro da imagem. Segundo Merleau-Ponty, o corpo tem a capacidade de mudar de nível e de compreensão de espaço. Vemos que as imagens virtuais, na relação oscilante que estabelecem com o real, criam uma sensação de real que pode ser parte material, parte imaterial, ou melhor, parte palpável, parte impalpável, em que não fazemos distinção entre os diferentes tipos de espaço e acabamos por habitar esse lugar híbrido e fragmentado. As obras de artemídia exploram essa possibilidade a partir da modulação de elementos como a luz das imagens projetadas, por exemplo, misturando linguagens que oscilam entre si e hibridizam percepções reais e virtuais, visíveis e mentais criando um espaço voltado à experiência do fluxo e constituindo o que chamamos aqui de topologia imaginária, sobre a qual discorreremos no próximo capítulo. 


\section{4.}

\section{Topologia imaginária: devaneio e imersão na experiência do corpo em espaço rizomático}

Nas observações que realizamos anteriormente acerca das obras de artemídia contemporânea podemos destacar a importância do percurso do participante pela obra, construindo sua própria interpretação e diálogo com o trabalho exposto ao escolher seu trajeto pelas instalações que chamam o corpo à experiência sensorial. Justamente pela proposta dialógica dessas obras, elas se constituem a partir de um híbrido de linguagens e categorias artísticas, chegando a provocar uma zona de indiscernibilidade entre o lugar do museu e a vida cotidiana (GOLDBERG;2014:23). Vemos que a dimensão do espaço, neste caso, ganha importância como local de experiência, de possibilidade de realização de dobras subjetivas no tempo. Nesse cenário, objetos artísticos se misturam a objetos não artísticos, propondo uma topologia fragmentada que se completa apenas mediante a presença ativa, não apenas corpórea, mas também metal e imaginária, do participador.

Antes de prosseguirmos, comecemos por compreender o porquê da escolha da palavra topologia. A estrutura que compõe essas instalações multimídia se sustenta na relação entre objetos, entre linguagens, entre obra e participador e outros entres. Além de se construir no espaço, essas instalações também acabam por construir um espaço (GOLDBERG;2014:34). Mais adiante discorreremos sobre a geografia rizomática que aí se estabelece, numa clara interlocução com Deleuze e Guattari. Por ora, nos voltamos a esses autores na busca por estabelecer ligações entre os conceitos de cartografia - amplamente trabalhado em suas obras - e o de topologia.

A cartografia é a arte de compor mapas. Deleuze e Guattari consideram a cartografia como um dos princípios básicos do rizoma, em oposição à decalcomania (1995:22), pois o mapa estaria voltado para uma experimentação ancorada no real; é uma construção aberta, suscetível de receber constantes modificações. Partindo dessa mesma noção, Julien Verhaeghe, em sua tese de doutorado defendida na Université Paris-VIII acerca da estética do fluxo na arte contemporânea, também acredita que a imagem, compreendida em seu devir, pode se constituir como uma cartografia (2010:155). Verhaeghe dá continuidade ao seu pensamento ao dizer que num espaço cartográfico, aberto, que proporciona a experiência 
individual mediante a relação da obra e do participador, a hecceidade ${ }^{109}$ seria pura geografia $(2010 ; 158)$. Essa afirmação nos leva à compreensão de que uma vivência ambientada no espaço da obra de artemídia pode, portanto, interferir na percepção individual do tempo, provocando um alargamento da percepção rumo ao devir puro, como também acreditam Deleuze e Guattari (1997).

Concordamos com o pensamento dos autores citados em sua relação com a cartografia e as possibilidades estéticas a ela atribuídas. No entanto, a noção mesma de mapa nos transmite uma ideia de representação visual que se caracteriza fortemente por sua bidimensionalidade. Ora, pensar o espaço de uma instalação implica pensar a tridimensionalidade arquitetônica da obra, o convite à imersão, o trânsito de um corpo que, para além de um sujeito observador de uma obra da qual antes não fazia parte (tal como se dá diante de um quadro pendurado na parede do museu), penetra a obra e, assim como os demais objetos que constituem a instalação, também se percebe como integrante do ambiente onde está. O aspecto bidimensional nos remete ao distanciamento entre participador e obra, enquanto o tridimensional, à imersão. Além disso, diferentemente da cartografia, que se refere aos mapas, a topologia se liga ao relevo. O relevo possui movimento: altos, baixos e pontos de destaque, o que pode se relacionar à forma como cada um percorre as experiências propostas pela artemídia a partir do diálogo com suas imagens mentais. A noção de topologia, portanto, nos parece mais adequada à abordagem das experiências subjetivas que ocorrem no interior da instalação de artemídia, tendo em vista que, em sua significação, carrega a noção de relevo.

Outra distinção deve ser feita ainda entre os vocábulos topologia e topografia. Dentre os significados atribuídos à palavra topografia ${ }^{110}$ também encontramos a ligação com o relevo. A topografia se constitui na descrição ou delineamento minucioso de uma localidade, trazendo configurações do relevo de um terreno. Encontramos aí uma definição importante que liga esse pensamento ao ato de descrever. Pensar um método que dialogue com a fenomenologia, como fazemos nesta pesquisa, implica reconhecer a relevância da descrição. Segundo Maffesoli, a descrição se insere no âmbito do "como", permitindo que o que anteriormente não passava de possibilidade possa se atualizar em realidade. Além disso, o sociólogo ainda aponta como a descrição não procura esgotar o mistério do ser e do mundo, mas contenta-se em apontar-lhes seus problemas, revelando suas contradições (1998:119).

\footnotetext{
109 "Os princípios característicos das multiplicidades concernem a seus elementos, que são singularidades; a suas relações, que são devires; a seus acontecimentos, que são hecceidades (quer dizer, individuações sem sujeito).” (DELEUZE, GUATTARI; 1995:8)

${ }^{110}$ Michelis Moderno Dicionário da Língua Portuguesa. Disponível em:

$<$ http://michaelis.uol.com.br/moderno/portugues/index.php>. Acessado em 23/04/2014.
} 
[...] o fato de descrever, enquanto tal, aquilo que é, não é de modo algum uma abdicação do intelecto, mas uma simples mudança de perspectiva: tratase de buscar a significação de um fenômeno em vez de estar focalizado sobre a descoberta das explicações causais. (1998:120)

A nomenclatura com a qual escolhemos trabalhar, a de topologia, pode ser compreendida a partir da mesma significação atribuída ao vocábulo topografia que citamos acima, porém agrega mais algumas relações de significação que se aproximam também da ideia de rizoma. A teoria da informação, por exemplo, enxerga na topologia uma rede em suas mais variadas formas, enquanto que para um ramo da geometria matemática, a topologia se baseia na noção de um espaço não-quantitativo em que apenas se consideram as relações de posição entre elementos das figuras - tal como num rizoma, que não se define pelos pontos, mas, pela passagem entre eles, constituindo-se pelo meio ou pela relação.

Além disso, na própria etimologia das duas palavras, apesar de encontramos uma semelhança dos antepositivos "topo" (lugar), a sequência de cada palavra determina mudanças importantes. Enquanto em topografia temos o vocábulo grafia, relacionado à escrita, na palavra topologia temos a relação com o conhecimento (logia) e, consequentemente, com o logos, conceito tão caro a Heráclito e que acabou por ser confundido com a noção de racionalidade mas que, para o filósofo, queria dizer bem mais do que isso, pois estava ligado a uma esfera única que abrange tanto o ser quanto o ente do homem - formando uma coletividade originária, como aponta Heidegger em seus estudos sobre o grego.

Seguindo esse raciocínio, enquanto em topografia teríamos uma significação aproximada a uma "escrita do lugar", na palavra topologia, por sua vez, a significação se volta a um “conhecimento global do lugar", um conhecimento que, por considerar a relação de ser e ente, de um ponto de vista da mundividência e não separação do sujeito e do objeto, concilia filosofia e experiência. Não é a escrita que nos interessa, pois aí estaríamos limitados à esfera do registro, mesmo que simbólico, mas ainda codificado e dependente de sinais. Na dimensão do logos estamos realmente em fluxo, como propõe Heráclito, numa coletividade que observamos mas da qual também fazemos parte, privilegiando a experiência. Dessa forma, por seu caráter mais abrangente, ratificamos nossa escolha pelo termo topologia ao invés de topografia.

Finalmente, retomando a relação entre topografia e cartografia, notamos que Verhaeghe, em sua tese, não faz muita distinção entre os dois conceitos, utilizando-os alternadamente, pois seu discurso parece partir de um ponto de vista que privilegia a questão geográfica, ou 
melhor, geoestética — num diálogo direto com o conceito de geopoética ${ }^{111}$, desenvolvido por Kenneth White. Para ele, o fluxo já nos coloca numa situação onde se torna possível colocar a questão da cartografia numa lógica de imanência e devir (2010:201). Ele dá continuidade a esse pensamento apropriando-se também do conceito de topologia: "não se trata de conceber um pensamento em termos de hierarquização de ideias, imagens ou pensamentos, mas de planificar os dogmatismos e ideologias que privilegiam as relações de vizinhança.”(2010:300). Dessa forma, a topologia - e a cartografia, segundo ele — nos permitiria vivenciar não mais a verticalidade da transcendência mas, sim, a horizontalidade da imanência, numa transição, como também propõem Deleuze e Guattari, da religião à filosofia.

Mais uma vez concordamos com os autores citados ao compreender que abordar a artemídia contemporânea de uma perspectiva fenomenológica do fluxo nos evidencia esse movimento que vai da transcendência religiosa (associada à arte durante muitos séculos até aproximadamente a época Renascentista) à imanência filosófica. No entanto, não acreditamos que as transformações que apontamos na arte contemporânea, dentre elas a maior participação do observador, bem como a composição da obra de arte como instalação e espaço de interação, leve a um completo distanciamento da transcendência. Merleau-Ponty traz uma importante definição do termo: "Quando digo que as coisas são transcendentes, isso significa que eu não as possuo, não as percorro, elas são transcendentes na medida em que ignoro aquilo que elas são e em que afirmo cegamente sua existência nua.’(2011:494). Acreditamos, como trataremos mais adiante, que o fluxo implica uma situação de oscilação harmônica entre contrários, ou seja, entre transcendência e imanência: trans-imanência que se dá por meio da experiência. Daí a necessidade de se pensar não em horizontalidades ou verticalidades separadamente, mas em relevos, que ora privilegiam uma dimensão, ora outra. E algumas vezes ainda se voltam a uma posição instável entre as duas, levando em conta o aspecto do movimento.

Para Sloterdijk, a relação em imanência estática não deixa espaços vazios para o devir (2003:539), pois se ocupa apenas da própria relação, deixando de considerar o aspecto subjetivo, tão importante para a realização da experiência na obra de artemídia contemporânea. Assim, mais que subjetividade, entramos na esfera mesmo da ontologia, em que a transcendência dialoga com a imanência. Sloterdijk afirma ainda que a imanência seria uma instância no interior em que, mais do que se voltar ao espaço, trata-se, na verdade, de

\footnotetext{
111 “É muito uma questão de um pensamento geográfico em White que se centra na noção de uma "meta-geografia”: seria uma geografia da imaginação, aquela que faz parte do jogo da viagem do pensamento mais do que aquela que se estuda no atlas"(VERHAEGHE:2010:298-299)
} 
relação. Assim, somos em microesferas, bolhas de relação onde prevalece o ser-com ao invés do ser-em, conforme nos aprofundaremos mais adiante.

Encontramos tal situação trans-imanente na obra Circuladô (2007), de André Parente, sobre a qual discorremos no capítulo anterior. Aí estamos diante de um espaço físico criado para a experiência do transe, do devir; experiência controlada pelo próprio participador por meio de suas escolhas e relação entre a disposição das imagens em grande formato da instalação, o corpo do participador e o aparato técnico que permite a interação. Para a compreensão da dinâmica que se dá nesse espaço, não serve a perspectiva planificada, cartográfica, pois devemos levar em conta todos os elementos citados anteriormente: a descrição de suas grandezas, a relação entre elas, seu aspecto técnico e tátil, a imagem, o convite à participação, a sensação corporal de estar no centro de um zootrópio gigante, além da vivência subjetiva e transcendente de um estado de consciência em transe que advém da experiência estética (aisthesis) e é contraditória por natureza, pois nos faz conhecer o sentimento de pertencer a algo maior que nós mesmos ${ }^{112}$, enquanto nos percebemos completamente sós numa ligação subjetiva com a obra. Nesse caso, temos de considerar a orientação horizontal em diálogo com a orientação vertical: trans-imanência.

Suzete Venturelli ainda aponta o fato de que com as novas tecnologias e as imagens virtuais, novas interfaces, monitores e controles transformam o espaço, que passa a participar de uma topologia eletrônica cujo ponto de partida é a trama da imagem digital (2011:91). Para a autora, o espaço "altera-se, muda de natureza e não se restringe mais às antigas cartografias, exigindo outros mapas-mundi." (2011:97). Diante disso, reafirmamos nossa escolha pela categoria topologia em detrimento de cartografia, pois acreditamos que o movimento intrínseco ao acidente do relevo se encontra mais ligado à percepção tridimensional que bidimensional do mapa, como também se encontra mais adaptado à fluida, dialógica e nada estática relação entre transcendência e imanência. Além disso, a associação com o aspecto da descrição — importante para se pensar um método fenomenológico — se adapta mais ao objeto do qual tratamos nesta pesquisa. Ainda podemos retomar o diálogo com o conceito de rizoma, fortalecendo a questão do estabelecimento de relações. Portanto, quando Verhaeghe diz que a realidade complexa é cartográfica, por deixar transparecer uma diversidade de espaços, práticas e funções em conexão (2010:470), preferimos pensar que essa complexidade deve ser observada de um ponto de vista topológico.

\footnotetext{
${ }^{112}$ Sensação que podemos ligar ao logos heraclitiano (como coletividade originária) ou ainda à noção de devir-imperceptível (devir todo mundo), presente em Deleuze e Guattari (1997).
} 
Outra questão que devemos considerar é que a topologia que propomos aqui ainda se constitui numa relação com o imaginário por meio da experiência e do devaneio. Partiremos inicialmente de uma compreensão acerca da geografia rizomática do movimento podendo, em seguida, entender melhor a aplicação do conceito de topologia. Depois, discutiremos como esses espaços rizomáticos tornam possível a experiência com o corpo do participador da obra de artemídia para, então, adentrar a esfera estética, em que consideramos o espaço como possibilidade de habitar o imaginário segundo uma relação perceptiva, envolvendo tanto estímulos visíveis quanto mentais e fortalecendo a sensação de imersão e do estar-junto.

\section{1: Uma geografia rizomática do movimento}

A noção de topologia, como vimos, carrega a sensação de movimento. Compreender como se dá esse movimento é desvendar os trajetos e percursos da topologia das obras de artemídia. Devemos entender que a geografia da qual tratamos aqui é uma geografia rizomática do movimento - daí, mais uma vez, a impossibilidade de nos voltarmos à cartografia. Esse rizoma, no entanto, só se completa mediante o trajeto percorrido pelo participador. Dessa forma, a topologia da obra é fluida, pois se configura somente no trânsito que se torna possível pelas passagens deixadas em aberto no diálogo entre linguagens dessas instalações multimídia que, em sua maioria, são híbridas.

A ideia de rizoma, segundo Deleuze e Guattari (1995), implica justamente uma multiplicidade da qual é possível partir linhas de fuga, ou seja da qual é possível subtrair o único. Cada vivência de obra resulta numa percepção e interpretação diferente. Mais do que obra aberta, como propunha Umberto Eco, a obra de artemídia é viva, se completa a partir do movimento e da relação, em constante fluxo. Dois dos princípios do rizoma, inclusive, segundo os dois autores, são o de conexão e de heterogeneidade, ou seja, qualquer ponto de um rizoma pode e deve ser conectado a qualquer outro e não cessaria de conectar cadeias de significação, reforçando sua natureza transitória e instável. Esses dois princípios dialogam também com o da ruptura, que reforça o fato do rizoma poder se interromper a qualquer momento, em qualquer ponto e, ainda assim, promover, por meio de outras multiplicidades, a criação de novas significações.

Deleuze e Guattari afirmam que essa multiplicidade rizomática, no entanto, se constitui num plano, uma vez que ocupam todas as suas dimensões. Nesse ponto compreendemos o porquê dos autores se referirem a uma cartografia e percebemos que não discordamos por completo do pensamento por eles elaborado. Apenas propomos dialogar esse pensamento com 
a percepção visual, sensorial e as vivências pessoais que se formam a partir dele. Ao pensar em uma multiplicidade que promove a relação entre exterior e interior, em todas as dimensões, imaginamos um rizoma tridimensional que se expande no espaço e que adentra corpos, imagens e objetos, com movimento e relevo. Mais uma vez, pensar numa planificação do rizoma nos remete à ideia de permanecer na esfera da separação entre sujeito e objeto, como se aí não houvesse diálogo. As linhas que ligam os diversos pontos, e que se transformam constantemente, formam um espaço onde o participador também se insere principalmente quando falamos das instalações de artemídia. Em tal espaço, não prevalece a representação tradicional, mas sim a atitude criativa, que emprega a imagem em relações de aproximação e vizinhança com o real, já que considera também as imagens mentais provenientes da participação subjetiva.

Tal imagem, para Warburg, projeta um duplo visível de seu referente, constituindo uma constelação que vai em direção à dimensão energética (apud SIEREK:2009:172), transitando do atual ao virtual, chegando mesmo a se desprender do espaço físico e referencial (Ibidem:164). Dessa forma, podemos conceber uma imagem sem espaço, porém idealizada a partir da relação com outras imagens numa experiência que, de início, se deu a partir de outra imagem (essa, sim, inserida num determinado espaço). Dá-se, aí, uma ruptura no rizoma que sustenta essas ligações, porém essa não é uma ruptura definitiva, mas, sim, uma reconfiguração da rede que sustenta essa constelação e, ao implodir a topologia visível cria, segundo uma visão fenomenológica, uma topologia imaginária, fruto da experiência subjetiva originada no visível. É um rizoma não apenas multidimensional, mas transdimensional, que se forma na interação entre experiências diversas tal como na engrenagem que movimenta o mundo fenomenológico, segundo Merleau-Ponty (2011:18).

Na obra Descendo a Escada $(2002)^{113}$, de Regina Silveira ${ }^{114}$, podemos observar um exemplo dessa topologia transdimensional e híbrida, constituída entre o referente visível e as imagens mentais individuais que completam a experiência. $\mathrm{O}$ ambiente que acolhe a obra é totalmente escuro e um projetor cria uma escada virtual, em movimento, simulando a descida de quatro andares. A escala e a perspectiva da imagem em movimento são pensadas de modo que o observador-participador da obra possa seguir o movimento, como se ele estivesse realmente descendo uma escada materialmente visível. Para aumentar a sensação de realismo, ouve-se o som de passos de outros supostos participantes que poderiam estar em outros

\footnotetext{
${ }^{113}$ Disponível em $<$ https://www.youtube.com/watch?v=Sbm6YJ_F9Xg $>$. Acessado em 10/04/2013. Vídeo em DVD em anexo: pasta 'Capitulo_04'> $>$ 01.DescendoEscada.mp4

${ }^{114}$ Regina Silveira (1939 - ) é artista e professora aposentada da USP. Site da artista: < www.reginasilveira.com >
} 
andares. A projeção nos leva a descer até uma sala escura e, ao chegar aí, a imagem retorna ao estado inicial, num movimento de trás para frente, rápido e vertiginoso.

A imagem luminosa é pobre de detalhes. São feixes de luz que mais se assemelham a uma estrutura inacabada, ou a um desenho apenas feito de linhas. Ao estimular uma sensação de imersão, mediante o movimento, a perspectiva e o som, o participante acaba por completar a sua experiência com a obra e, consequentemente, da imagem, relacionando-a às imagens mentais de escadas que estão guardadas em sua memória. Que sejam as escadas da casa da infância (como talvez o fizesse Bachelard!), ou escadas nunca percorridas, mas já vivenciadas pela imaginação através das pinturas de Escher $(1898-1972)^{115}$, por exemplo.

\footnotetext{
${ }^{115}$ Artista gráfico holandês. Para conhecer mais sobre o artista: < http://www.mcescher.com/ >
} 


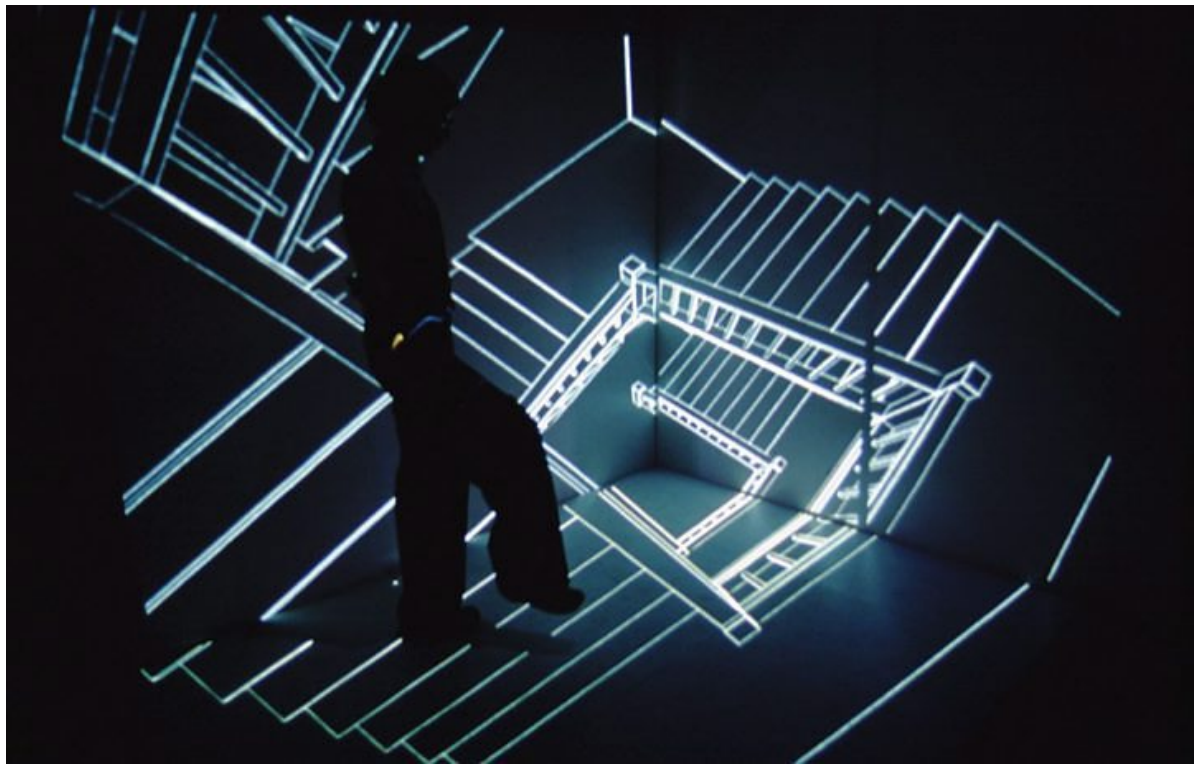

Figura 33: Descendo a escada (2002), de Regina Silveira

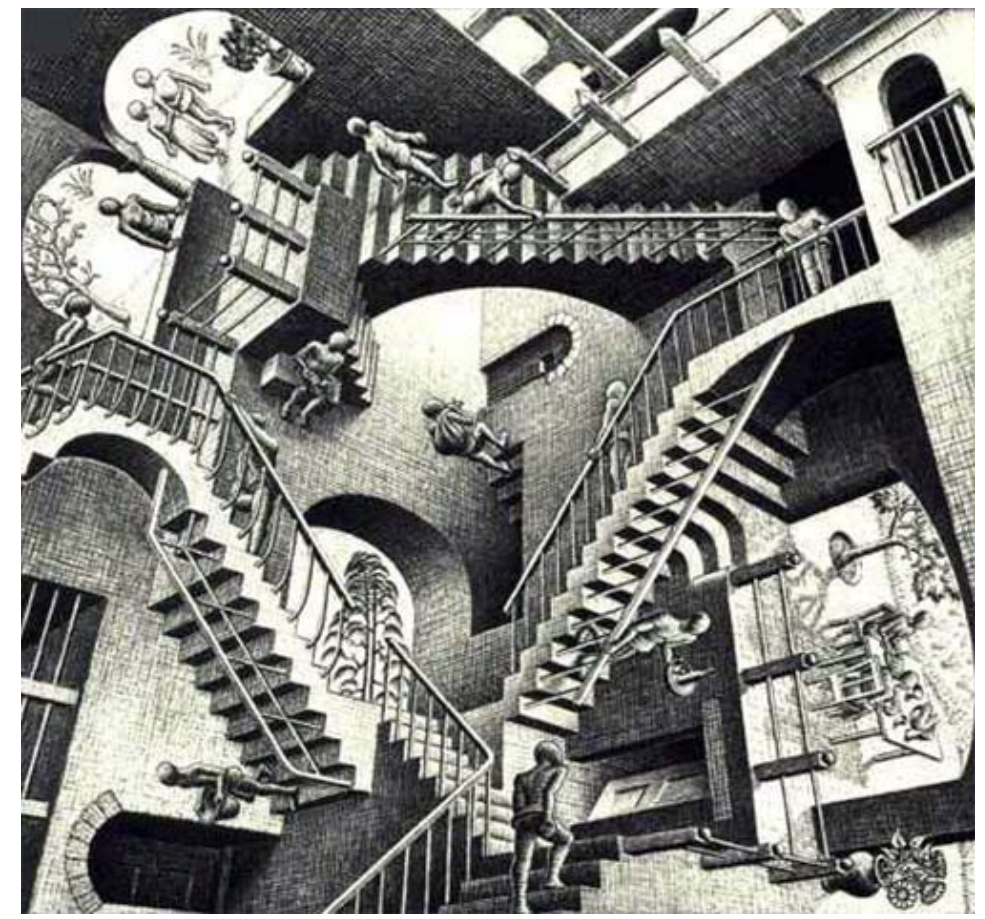

Figura 34: Relatividade (1953), M.C. Escher

A experiência proposta por Regina Silveira nos leva a esse estado de entre-mundos que se forma na oscilação entre luz e sombra, entre real e virtual, buscando seus referenciais entre imagens projetadas e mentais. O que resulta daí é uma imagem mista e nebulosa que irá formar, para o participante, mais um parâmetro visual de "escada", a partir de uma relação entre imagens, matérias e sensações. Uma experiência que nos coloca na presença de um 
devir, como propõe Bergson em relação ao fluxo, e que se manifesta numa topologia imaginária que, por meio da oscilação, constrói a percepção híbrida e complexa da obra.

Segundo Bachelard, o espaço percebido pela imaginação não pode ser o espaço entregue à mensuração por um geômetra, mas, sim, um espaço vivido com todas as parcialidades da imaginação. É um espaço que atrai: "No reino das imagens, o jogo entre o exterior e a intimidade não é um jogo equilibrado. [...] Incessantemente, a imaginação imagina e se enriquece com novas imagens."(2008:19). Nessa dinâmica, o espaço retém o tempo, que se desenrola no ritmo da experiência e não mais de forma linear: "nosso espaço tornou-se temporal ou nosso tempo se espacializou, perguntam-se vários pensadores." (VENTURELLI; 2011:23).

Para Edmond Couchot, a relação espaço-tempo, quando aparelhada por uma rede numérica, leva o sujeito a adquirir uma espécie de ubiquidade dialógica alimentada por uma percepção rizomática fruto da relação mesma entre homem e máquina (1998:230). Uma questão levantada pelo autor é que, nesse cenário, nos encontramos num estado a meio caminho entre o individual e o coletivo, indo ao encontro à filosofia de Deleuze acerca do espaço, em que se concebe uma dissolução da separação entre o interior e o exterior: "o espaço-tempo deixa de ser um dado puro para se tornar o conjunto ou o nexo das relações diferenciais no sujeito, e o próprio objeto deixa de ser um dado empírico para se tornar produto dessas relações na percepção consciente.” (1991:134). Para o filósofo, isso se manifesta na imanência da percepção e do pensamento, ou, como preferimos abordar, na trans-imanência.

Não apenas na arte tecnológica ou na artemídia podemos encontrar obras que nos permitem vivenciar uma experiência de espaço temporalizado ou do tempo especializado. $\mathrm{Na}$ arte cinética encontramos vários experimentos, como os Penetrables ${ }^{116}$ de Jesús-Rafael Soto $^{117}$ ou — não por simples coincidência — nos Penetráveis ${ }^{118}$ de Hélio Oiticica ${ }^{119}$. Ambos artistas começaram suas séries de obras intituladas respectivamente com os nomes acima no final da década de 1960. Para Oiticica, a série de instalações em forma de labirinto compostas

\footnotetext{
${ }^{116}$ Disponível em <http://www.centrepompidou.fr/cpv/ressource.action?param.id=FR_Rafdf442804ba645bcaa7eaee829a677\&param.idSource=FR_E-75e251a21358a53876e $4707 \mathrm{ac} 8 \mathrm{c} 185 \mathrm{cb}>$. Acessado em 02/05/2014. Vídeo em DVD em anexo: pasta ‘Capitulo_04' >> 02.Penetrable_Soto.mp4

${ }^{117}$ Jesús-Rafael Soto $(1923$ - 2005) foi um pintor e escultor venezuelano que experimentava com a arte abstrata e o movimento, aproximando-se da arte cinética, quando então começou a realizar os conhecidos penetrables. Site do artista: $<$ www.jr-soto.com/ >

${ }^{118}$ Disponível em $<$ https://www.youtube.com/watch?v=tA3UWxMgzLQ> Acessado em 02/05/2014. Vídeo em DVD em anexo: pasta 'Capitulo_04’>> 03. Penetravel_Oticica.mp4

${ }^{119}$ Helio Oiticica $(1937$ - 1980) foi pintor, escultor, artista plástico e de performance. Dialogou com o movimento concreto e neoconcreto brasileiro e foi um dos primeiros artistas brasileiros a conceber o observador como participador, levando-o a interagir ou a percorrer sua obra. Site do artista: < www.heliooiticica.org.br/ >
} 
por uma infinidade de tipos de material tinham o intuito de fazer o participador passar por experiências sensoriais diversas envolvendo todos os sentidos e que se desenrolavam conforme o trajeto escolhido por aquele que percorria a obra, durante o tempo que desejasse percorrê-la. Seja numa passagem de vislumbre ou de experimentação dos possíveis caminhos, o estímulo sensorial estava presente: pés descalços no encontro com diferentes texturas, as cores das paredes, os objetos do cenário, dentre outros. O espaço de Oiticica se constitui na experiência do tempo que dedicamos a ela, não o tempo cronológico, mas aquele subjetivo da relação participador-obra.

Já na obra de Soto acreditamos encontrar uma experiência de integração-desintegração do sujeito no espaço. A concepção de espaço em Soto é móvel, ou seja, diferente do labirinto de Oiticica. Os Penetrables se constituem por materiais como tiras de metal, papel ou plástico penduradas que delimitam o espaço da interação mas que nos dão a sensação de que o espaço se molda ao redor de nós mesmos, enquanto nos movimentamos através dele, como se fôssemos capazes de deslocar uma massa de espaço, assim como deslocamos o ar. A obra de Soto nos permite vivenciar o sentimento físico da vibração dos elementos que, sozinhos, parecem isolados mas, em conjunto, parecem formar um espaço fluido e imaterial que convida à interação e se transforma constantemente mediante essa mesma interação. A noção de rizoma, aí, parece facilmente se adaptar ao espaço, graças aos trajetos diversos de vários participadores ou ainda à disposição também em labirinto. Nos esquecemos, no entanto, que ainda outro rizoma se forma, espacializando a experiência subjetiva: aquele resultante do encontro dos diferentes tempos dos sujeitos que vivenciam as obras. Dessa forma, vemos que uma geografia rizomática não se constitui apenas na materialidade do espaço em si, mas também na imaterialidade da experiência que, por sua vez, também é capaz de espacializar o tempo. 


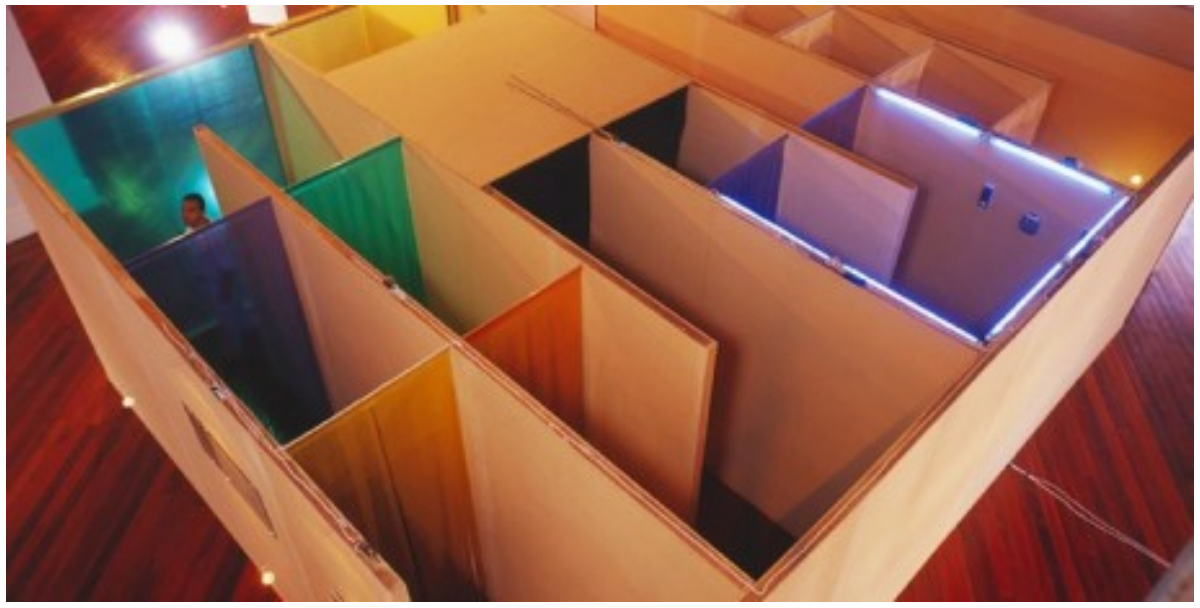

Figura 35: Um dos Penetráveis (1972) de Hélio Oiticica

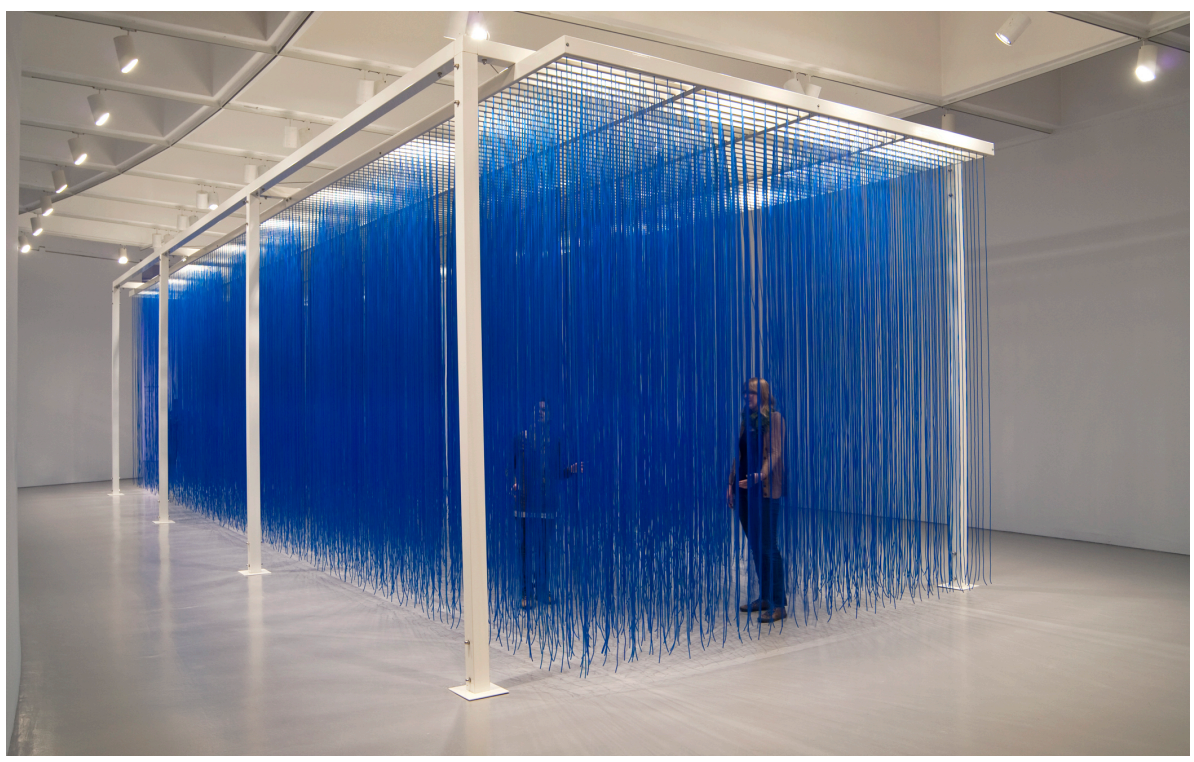

Figura 36: Blue Penetrables (1969), Jesús Rafael Soto

Para Itzhak Goldberg, a penetração do espaço literal ainda pode ser considerada como uma retomada da passagem da representação à apresentação, introduzida pelas primeiras obras abstratas (2014:119). Além da diferença de proporção entre as obras de instalação e as obras abstratas, pode-se destacar que a arte abstrata tratava de uma apresentação passiva, da ordem do visual, em que o espectador se situava frente a uma superfície bidimensional que delimitava seu espaço, isolando-a do mundo. Já na instalação, os objetos do cotidiano se integram ao espaço e ao espectador, permitindo estabelecer relações entre todas essas instâncias. Estamos diante de uma "escultura expandida", referindo-se ao termo usado por Rosalind Krauss ao pensar os trânsitos e passagens a partir da arte escultórica à instalação (1981). 
Nesse sentido, podemos citar a obra The Matter of Time (2005), de Richard Serra, que utiliza chapas de aço em grandes dimensões, inclinadas, dispostas em forma de ondas, curvas, elipses e círculos, criando uma tensão entre a materialidade dura do aço e as disposições orgânicas da forma. A inclinação das chapas e seu tamanho monumental dão uma sensação de movimento e vertigem, como se ao passar ao redor e entre as esculturas, as paredes que as constituem estivessem prestes a cair sobre o participador-transeunte. Serra dispõe suas peças num diálogo com a arquitetura ambiente, criando caminhos não apenas internos às esculturas, mas também outros que se estabelecem entre elas, relacionando o espaço interior ao exterior da obra. Para Rosalind Krauss, a intenção do artista é protestar contra a escultura como metáfora de um corpo dividido entre dentro e fora. Ele propõe um percurso onde esses dois espaços se misturam e que deve ser percorrido de acordo com as escolhas do participador, pois a própria existência da escultura depende desse momento individual de passagem $(1981: 269)$.

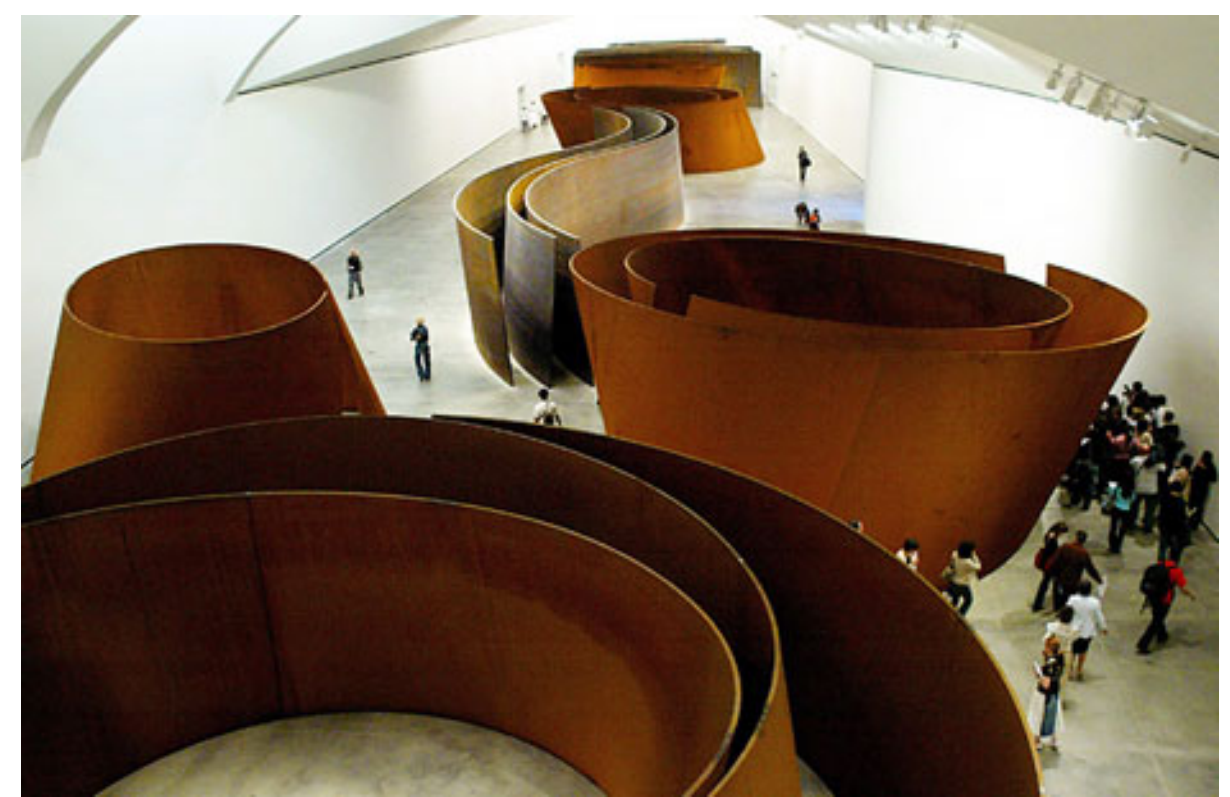

Figura 37: The matter of time (2005), Richard Serra

Ao nos voltarmos para a artemídia, devemos pensar que a noção espacial das instalações não é apenas fruto das redes multimídia, digitais ou tecnológicas, mas de redes que se comunicam e se formam entre visibilidades, materialidades, percursos e, principalmente, experiências diversas. Acontece que as facilidades de se explorar o hibridismo de linguagens, proporcionado pelas plataformas multimídia e digitais, nos levam a observar e questionar a multiplicidade que se manifesta nesses tipos de obra. Para Arlindo Machado, vivenciamos o que se convencionou chamar de segundo barroco, ou neobarroco, caracterizado pela 
instabilidade: "Do espaço isotópico da figuração clássica, [...] passamos agora ao espaço politópico, em que elementos constitutivos do quadro migram de diferentes contextos espaciais e temporais e se encaixam [...] em configurações híbridas" (2010:76).

Podemos dizer que pensar numa topologia imaginária consiste em pensar também numa geografia rizomática do movimento que é híbrida entre visível e imaginário, entre real e virtual, entre percepção e experiência, pois se baseia na experiência estética (aisthesis). As imagens que constituem essa rede topológica são, como propõe Sierek, imagens-pássaro (images oiseaux): "Leves e volúveis, elas estão em constante movimento.” (2009:197) para, assim, permitir o trânsito entre interior e exterior, sujeito e objeto — transcendência imanente.

\subsection{A experiência do corpo funda uma percepção do espaço}

Criar uma topologia imaginária consiste em estabelecer um diálogo entre imagens visíveis e mentais. A experiência que aí se constrói parte de uma percepção que não deixa de retomar as experiências de percepções anteriormente vividas. Para Merleau-Ponty, a significação daquilo que é percebido forma uma constelação de imagens que reaparecem sem razão (2011:38) num diálogo entre exterior e interior. Bachelard também se questiona sobre como o aparecimento de uma imagem efêmera e singular pode reagir em diversas almas, criando, muitas vezes, uma espécie de transubjetividade que ultrapassa o senso comum. Para o filósofo, apenas a fenomenologia, ao considerar o início da imagem numa consciência individual, pode ajudar a compreender essa subjetividade que caracterizamos como rizomática.

O fenomenólogo, segundo Bachelard, parte de observações simples para chegar à experiência, compreendendo que a imagem vem antes do pensamento e forma uma consciência sonhadora (2008:3-4). Com a contribuição do autor podemos compreender melhor, então, a afirmação de Merleau-Ponty em relação à composição da percepção — sobre a qual apenas demos um vislumbre logo acima. Ele afirma que apenas a "projeção das recordações" não é o suficiente para se introduzir na percepção atual uma atividade mental. A construção perceptiva é também uma atividade empírica que se baseia nos estados de consciência: parte de estímulos externos e percepções visíveis para dialogar no campo do invisível, gerando tal constelação de imagens que funda a experiência. Dessa forma, não há como negar que cada sujeito perceba a mesma imagem, cor ou nota musical a partir de um estímulo externo. O que muda, segundo Deleuze, é a atualização dessa percepção em cada um, reforçando a noção de que a experiência se estrutura numa percepção elaborada sobre 
múltiplos estados de consciência (dentre as quais, também a consciência sonhadora de Bachelard).

\begin{abstract}
Todas as mônadas percebem, assim, o mesmo verde, a mesma nota, o mesmo rio, e em cada caso é um só e mesmo objeto eterno que se atualiza nelas. Mas, por outro lado, a atualização é diferente de acordo com cada mônada, e nunca é o mesmo verde, no mesmo grau de claro-escuro que duas mônadas percebem. Dir-se-ia que cada mônada, de um lado, privilegia certas relações diferenciais (que lhe dão assim percepções exclusivas), e que, por outro, deixa as outras relações diferenciais abaixo do grau necessário, ou melhor, deixa uma infinidade de pequenas percepções subsistir nela sem de modo algum entrar em relações. Portanto, no limite, todas as mônadas tem a infinidade de pequenas percepções compossíveis, mas são próprias de cada mônada as relações diferenciais que nela vão selecionar algumas dessas percepções para produzir percepções claras. É nesse sentido que cada mônada, como vimos, expressa o mesmo mundo que as demais, mas não deixa de haver nela uma zona de expressão de qualquer outra mônada: "seu departamento" (DELEUZE;1991:136).
\end{abstract}

Dessa forma, a percepção ganha uma dimensão dupla que se constitui na relação entre o externo e o interno e assume, segundo Deleuze, uma característica alucinatória. Para o filósofo a percepção não tem um objeto, mas remete a um mecanismo psíquico das relações entre as pequenas percepções, constituindo um mundo próprio (1991:141). A primeira etapa da percepção, portanto, iria do sujeito ao objeto, pois as pequenas percepções evocam a vibração na matéria do objeto, levando a uma percepção consciente pelo órgão receptor nesse mesmo sujeito e fazendo ambos (sujeito e objeto) coincidirem. A percepção, dessa maneira, pode ser compreendida como uma representação do objeto e do mundo (repercutindo o ser-aí heideggeriano) pois, segundo Deleuze, as dobras internas que constituem o sujeito se assemelham à matéria que também constitui as dobras externas (1991:147-148).

Tal experiência perceptiva nos abre para uma sensação de ser-um com a obra, de fazer parte dela não apenas pela ação que ela nos demanda, mas de fundir-se à sua matéria: fluxo heraclitiano que remete à imersão no rio. Nesse caso, os elementos físicos e materiais que compõem a obra produzem a tal vibração da qual fala Deleuze, que parte de um estímulo externo, reverbera internamente para novamente voltar-se ao exterior, mas transformada pela passagem entre as dobras internas. Basta nos lembrarmos da vivência proporcionada pela obra Standing Wave (2013), de Annica Cuppetelli e Cristobal Mendoza, sobre a qual falamos no capítulo anterior, ou ainda os Penetrables de Jesús-Rafael Soto.

Neste ponto, podemos retomar o pensamento de Merleau-Ponty que diz que "perceber não é experimentar um sem-número de impressões que trariam consigo recordações capazes de completá-las, é ver jorrar de uma constelação de dados um sentido imanente sem o qual 
nenhum apelo às recordações seria possível." (2011:47). De forma que, quando nos recordamos, as experiências que resgatamos são vividas novamente, em outra situação espaço-temporal: vivências internas que se tornam possíveis por empréstimo do estímulo de uma experiência externa, àquela proposta no momento. A percepção, portanto, pode ser considerada um conhecimento originário, pois aquilo que agora parece indeterminado para mim, tornar-se-á determinado para um conhecimento mais completo que está antecipadamente realizado no objeto (MERLEAU-PONTY;2011:85-86).

Para Merleau-Ponty ver um objeto significa habitá-lo (2011:105), percebendo-o sob diferentes ângulos. Vê-se, aí, a importância da vivência do espaço na percepção do objeto fundando a experiência, tal como se dá nas instalações de artemídia contemporânea em que o corpo é convidado a habitar o espaço projetado para a realização de tal experiência. Dessa forma, não nos situamos apenas no espaço, mas somos-com ele a tal ponto que o filósofo francês chega a afirmar que não haveria espaço se não tivéssemos corpo (Ibidem:148). Aí, o corpo não é mais um objeto do mundo, mas sim o meio de comunicação com ele: "Ser uma consciência, ou, antes, ser uma experiência, é comunicar interiormente com o mundo, com o corpo e com os outros, ser com eles em lugar de estar ao lado deles." (Ibidem:142).

Vejamos o exemplo da obra Ondas: Um Dia de Nuvens Listradas Vindas do Mar $(2006)^{120}$, de Katia Maciel. Em várias de suas obras, a artista trabalha com o conceito de presença por meio de sensores que captam o movimento do participador, desencadeando a interação. Nessa obra, especificamente, ao adentrar a sala vemos uma projeção sobre a parede ao fundo que mostra um vídeo de ondas quebrando na praia, acompanhadas do som característico da ação, o que intensifica ainda mais a sensação proposta pela imagem. No chão vemos a projeção de uma imagem de areia, estática. Ao adentrar o espaço da videoinstalação, nossa presença altera o vídeo que é projetado no chão. Agora as ondas que quebram na praia, vistas na parede, continuam na projeção do chão e nos atingem, como se passassem por baixo de nossos pés, assim como acontece quando estamos à margem da praia entre o mar e a terra. Também o som que acompanha essa ação é o mesmo de quando a onda toma a areia e logo em seguida retorna ao mar. A projeção continua enquanto ali permanecermos.

\footnotetext{
${ }^{120}$ Disponível em < http://vimeo.com/48024392 >

Acessado em 02/05/2014. Vídeo em DVD em anexo: pasta 'Capitulo_04'>> 04. Ondas.mp4
} 


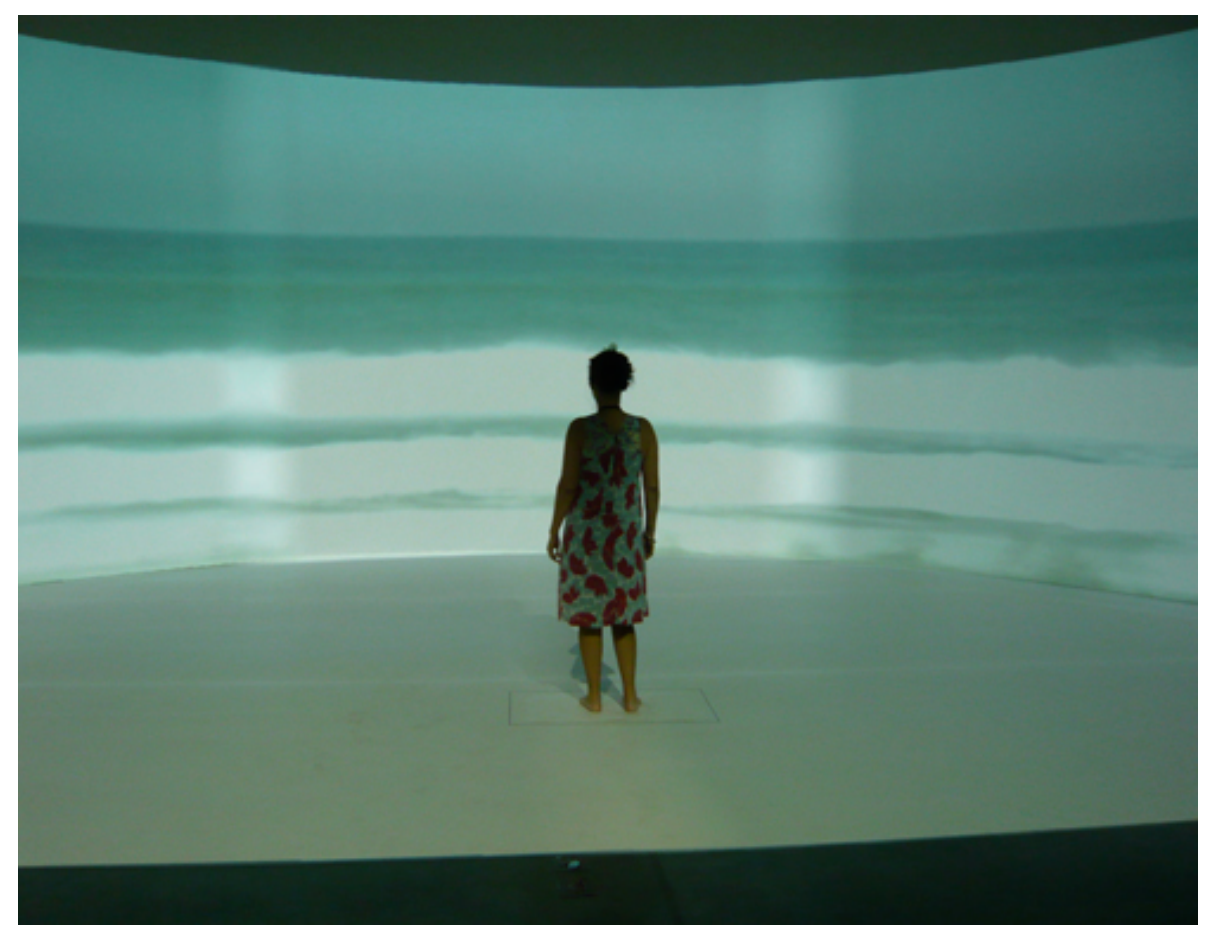

Figura 38: Ondas: Um Dia de Nuvens Listradas Vindas do Mar (2006), Katia Maciel

A temporalidade da obra não é linear, ela é determinada pelo participador, pela sua relação de movimento com a instalação e se desenrola na dimensão vertical da contemplação subjetiva - sublime matemático, como proposto por Kant ${ }^{121}$, diante da sensação de infinito trazida pela imagem do oceano, por sua vez também matemático, visto que expresso por imagens binárias digitais. Somos tomados pela imagem luminosa, ela nos atravessa de cima a baixo, espalhando-se sob nossos pés. Estamos imersos na obra e vivenciamos uma experiência transdimensional durante o tempo da experiência participativo-contemplativa, pois nos transportamos para a praia sem sair do prédio do museu. As imagens, o som, a temporalidade, tudo se relaciona às experiências semelhantes já vividas e, retomando o pensamento de Merleau-Ponty, não apenas as recordamos novamente diante do estímulo externo, mas as revivemos em uma nova situação espaço-temporal.

A participação nessas obras, que muitas vezes requer um diálogo entre o estímulo visível e o invisível, pode, segundo Edmond Couchot, ser concebida como real (1998:87), desenvolvendo uma nova matriz perceptual tanto no sentido que envolve seu aspecto digital

\footnotetext{
${ }^{121}$ Em seu livro Crítica da Faculdade do Juizo, Kant afirma que experiência do sublime se encontra entre o horror e o prazer e estaria ligada à percepção da falta de limites, ou ao "absolutamente grande" (2008:93). O sublime, segundo o filósofo, não deve ser procurado nas coisas da natureza, mas em nossa disposição de espírito e ideias (Ibidem:96). No caso de um juízo estético de um objeto sem forma, em que recorreríamos ao sublime, a avaliação da quantidade pode constituir o início do processo (Ibidem: 92-93). No entanto, como na avaliação numérica das grandezas não existe um número máximo (visto que os números vão até o infinito), enquanto na avaliação estética esse máximo é imposto pela subjetividade, podemos até começar o julgamento pelo aspecto quantitativo, mas acabamos sendo levados ao estético, chegando ao sublime-matemático (Ibidem:97).
} 
quanto no sentido psicológico, gerando uma corporeidade que se situa entre a carne e o cálculo (Ibidem:152). Para Suzete Venturelli, estamos diante de um novo paradigma que irá produzir uma subjetividade maquínica. Concordamos com a autora, porém vislumbramos o mesmo processo em sentido inverso: no lugar de conceber uma subjetividade maquínica, acreditamos, assim como propõe Frank Popper, numa humanização da tecnologia por meio da interatividade e da imersão multissensorial tornadas possíveis pela imaginação artística (2001:355). As imagens resultantes dessa interação possibilitam uma percepção que vai além do olhar, que envolve todo o corpo e penetra pelos outros sentidos, tais como audição e tato: "Para o autor [Philippe Quéau], as imagens que surgiram do novo paradigma estético de que nos fala Félix Guattari nunca são somente imagens e se diferenciam destas por possuírem espaço ao redor do que é visualizado e de quem interage."(VENTURELLI;2011:165).

Essa relação espaço-corpo, nos leva a observar com maior atenção o movimento pois, considerando o corpo em movimento, vê-se melhor como ele habita o espaço e, consequentemente, o tempo (MERLEAU-PONTY:2011:149). Quando o corpo incorpora o movimento ao seu mundo, ou seja, à experiência, aquele torna-se instrumento de visualização e percepção de coisas para além da representação. Aí habitamos o espaço e o tempo concomitantemente (2011:192), ou seja, somos no espaço e no tempo, nos aproximando do pensamento de Bergson acerca do movente e sobre como podemos apreender plenamente um mundo em movimento - fazendo parte desse mesmo movimento. Uma postura que não apenas se relaciona a uma questão de percepção mas, também, nos serve como um exercício metodológico diante da observação de obras tais como as que trazemos aqui, caracterizadas pelo que chamamos de estética do fluxo.

A constituição de um nível espacial é apenas um dos meios da constituição de um mundo pleno: meu corpo tem poder sobre o mundo quando minha percepção me oferece um espetáculo tão variado e tão claramente articulado quanto possível, e quando minhas intenções motoras, desdobrando-se, recebem do mundo as respostas que esperam. Esse máximo de nitidez na percepção e na ação define um solo perceptivo, um fundo de minha vida, um ambiente geral para a coexistência de meu corpo e mundo (MERLEAUPONTY;2011:337)

Rejane Cantoni e Daniela Kutschat, ao desenvolverem a obra OP_ERA Hyperviews (2004) ${ }^{122}$, procuraram proporcionar uma experiência do corpo que se encontra na vivência do espaço-tempo. A instalação imersiva tem o objetivo de explorar a representação de objetos quadridimensionais em espaços tridimensionais. Cinco paredes de um cubo escuro são

\footnotetext{
${ }^{122}$ Disponível em < https://www.youtube.com/watch? $\mathrm{v}=\mathrm{qSU}$ UuYdDriKM $>$ Acessado em 02/05/2014. Vídeo em DVD em anexo: pasta 'Capitulo_03>> 05.OP_ERA_Hyperviews.mp4
} 
preenchidas por flashes de 688 lâmpadas que emitem luzes sincronizadas e de frequência variante, correspondendo a fragmentos da imagem de um hipercubo desdobrado (um cubo no espaço de quatro dimensões) que se desloca entre as paredes. Os estímulos luminosos das formas projetadas, graças ao fenômeno da persistência da retina que forma uma pós-imagem no momento seguinte ao estímulo luminoso, provocam a percepção do hipercubo na mente do observador como se ele estivesse inserido nele, acompanhando seu movimento de translação e podendo experimentar, assim, o fenômeno do espaço-tempo da quarta dimensão.

Vivenciar tal sensação nos leva a questionar a própria noção de espaço pois, para além de uma definição que abrange o ambiente em que as coisas se dispõem, o espaço, nesse caso, seria o meio pelo qual a posição das coisas se torna possível, numa potência universal de conexões, segundo aponta Merleau-Ponty (2011:328). Passamos de um espaço espacializado a um espaço espacializante, que se constitui no diálogo com o tempo. No primeiro caso, segundo o filósofo francês, abordamos o aspecto físico, já no segundo, o aspecto geométrico, onde uma mudança de lugar não alteraria o móbil e, consequentemente, uma posição pura, assim como se dá na obra OP_ERA Hyperviews (2004) por meio da pós-imagem do hipercubo percebida no movimento das luzes oscilantes: "a relação do móbil ao seu fundo passa por nosso corpo.’(MERLEAU-PONTY;2011:373).

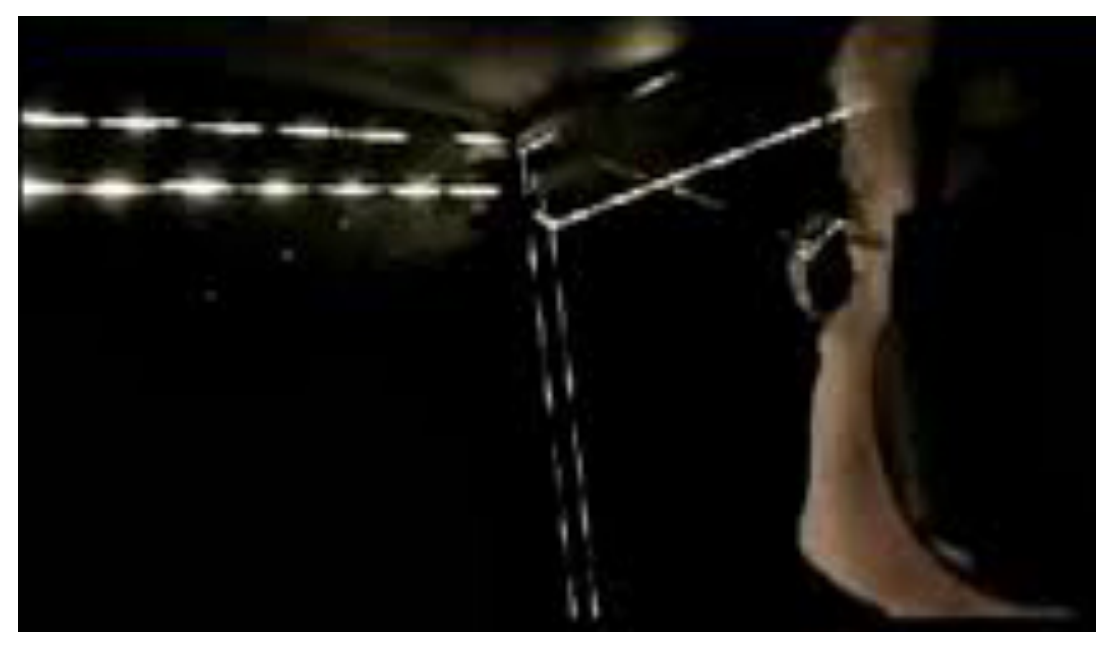

Figura 39: OP_ERA Hyperviews (2004), Rejane Cantoni e Daniela Kutschat

Itzhak Goldberg (2014:195), ao analisar as instalações multimídia, afirma que com o vídeo e as novas mídias temos uma imagem móvel que pode tanto dilatar quanto multiplicar o espaço, provocando deslocamentos visuais diversos que se desenrolam juntamente ao movimento do espectador, diferentemente do que se daria numa tela de computador, por exemplo. Dessa forma, muitas vezes provoca-se um efeito de descentralização, desorientação 
e até mesmo de flutuação, reforçada também pela oscilação entre luz e sombra - como vimos anteriormente na obra Standing Wave (2013), de Annica Cuppetelli e Cristobal Mendoza. O corpo aí se encontra deslocado, a percepção do espaço alterada, assim como a consciência e o tempo do espectador: vertigem da visão que amplia a percepção do espaço.

Merleau-Ponty afirma que Kant discorre acerca do movimento gerador de espaço, um movimento intencional, diferente daquele que se dá no espaço, ligado ao corpo passivo, em que o mundo se encontra como um conjunto aberto de coisas em direção às quais nós nos projetamos: "O projeto de movimento é um ato, quer dizer, ele traça a distância espaçotemporal atravessando-a.”(2011:518) - tal como pudemos observar na obra Descendo a Escada (2002), de Regina Silveira. Segundo Merleau-Ponty, a experiência que aí se desenrola parte de um campo visual em que, inicialmente, o sujeito parece alheio à paisagem, no entanto, ao decorrer da experiência, constata-se uma fase intermediária em que o corpo parece ser estranho e a paisagem familiar. Já vivendo na paisagem, a perturbação experimental é atribuída ao corpo, necessário à participação no espetáculo, reforçando o poder do sujeito sobre seu mundo, o que constitui a origem do espaço (2011:338). Podemos dizer, portanto, que o ser é no espaço e essa relação é fundante para sua percepção de corpo e mundo na experiência desse mundo, estabelecendo uma comunicação que, conforme acredita MerleauPonty, é mais antiga que o pensamento (Ibidem:342).

Outra obra de Katia Maciel que se baseia no conceito de presença e de movimento no espaço é Infinito fim (2008) ${ }^{123}$. Nela vemos inicialmente uma projeção da imagem de uma porta fechada. Ao nos aproximarmos da tela, a porta se abre e à medida que continuamos a nos acercar, outras portas continuam a se abrir, uma após a outra, em sequência. Quando nos afastamos, as portas se fecham. Podemos perceber como, num primeiro momento, ao ver a imagem da porta fechada, temos a predominância da impressão bidimensional e não nos sentimos inseridos nela. Quando o movimento de proximidade da porta realizado pelo corpo desencadeia uma ação na imagem, que agora mostra profundidade, temos a sensação de estar num corredor fundo que nos convida a percorrê-lo, mesmo se tratando de uma imagem plana. Segundo Merleau-Ponty, a profundidade revela o elo do sujeito ao espaço (2011:360). Dessa forma, a sensação de poder do sujeito sobre o mundo se intensifica quando percebemos que nosso movimento controla também o movimento do abrir e fechar das portas e a própria noção de espaço que aumenta ou diminui sua profundidade conforme nos deslocamos, escolhendo nos aproximarmos ou nos afastarmos da obra.

\footnotetext{
${ }^{123}$ Disponível em < http://www.katiamaciel.net/trabalhos_KatiaMaciel_2008-2009.htm > Acessado em 02/05/2014. Vídeo em DVD em anexo: pasta 'Capitulo_04'> $>06$. Infinito_fim.mp4
} 
$\mathrm{Na}$ duração dessas experiências adentramos um mundo da espacialidade original, como propõe Merleau-Ponty, no qual não há distinção entre visível e imaginário (2011:380). Os povos arcaicos, por viverem no mito, não conseguiam ultrapassar esse espaço existencial e, por isso, os sonhos contavam tanto quanto as percepções. Nessa perspectiva, o espaço do sonho, o espaço mítico são, sim, espaços verdadeiros e formam, para além de uma espacialidade original, uma espacialidade do sujeito (Ibidem:386-387). Ele é híbrido, resultante do diálogo entre o estímulo visível e o imaginário e se constitui, portanto, nesse espaço vivido, enraizado na experiência do corpo. É um espaço aberto mais ao devaneio que ao sonho, pois quando falamos de devaneio, permanecemos despertos. Nesse sentido, formase um elo entre subjetividade e objetividade, tão presente na consciência mítica ou infantil, pois aí adentramos um espaço onde "nunca vivo inteiramente nos espaços antropológicos, estou sempre ligado, por minhas raízes, a um espaço natural e inumano.”(MERLEAUPONTY;2011:393).

\subsection{Espaços do devaneio: habitar o imaginário no universo das imagens técnicas}

Os espaços híbridos entre real e imaginário, como vimos, se embasam fortemente sobre a dimensão da experiência corporal e, diante disso, tornam mais evidente a apropriação do espaço pelo sujeito, que não apenas passa por ele, mas vivencia-o; habita-o. Essa dinâmica pode ser melhor compreendida pelos estados de devaneio. Bachelard afirma que o devaneio é uma fuga para fora do real, mas nem sempre em direção a um mundo irreal (2006:5). Nesse sentido, falamos de uma distensão da consciência, que permite criar e habitar uma topologia imaginária percebida mas, muitas vezes, não visível.

O devaneio se liga mais à experiência que o sonho, pois o devaneio desencadeia processos de recordação no sentido defendido por Merleau-Ponty, que implica reviver tal recordação diante de uma nova situação espaço-temporal. Apenas resgatar uma lembrança da memória, sem vivenciá-la, é o tipo de situação ligada ao sonho, como propõe Bachelard: "A memória sonha, o devaneio, lembra." (2006:20). No devaneio ainda subsiste uma clareza de consciência necessária à percepção e, consequentemente, à experiência. A consciência que imagina mantém a imagem fruto de sua imaginação num estágio de imediaticidade que acaba por constituir o próprio ser. Não é uma imagem passiva, ela nos desperta de nosso torpor ao criar um mundo próprio. Torna-se possível a elaboração de um mundo estratificado em diversos níveis ontológicos, típico das possibilidades virtualizantes que a tecnologia nos 
permite hoje por meio das imagens técnicas - para nos referirmos ao termo tão amplamente empregado por Flusser ${ }^{124}$.

Enquanto o sentido das imagens tradicionais seria o de possibilitar uma orientação no mundo, o sentido das imagens técnicas seria o de gerar sentido (FLUSSER; 2008:50). Os aparelhos que geram imagens não são mais refletores, mas projetores e, dessa maneira, podemos criar novas realidades pela manipulação das imagens: "As imagens técnicas tornam imaginável a abstração mais abstrata e o inconcebível em concretamente vivenciável (Ibidem:127). Como, então, distinguir entre essa realidade imaginada e a realidade concreta?

Acreditamos que no universo das imagens técnicas não faz sentido fazer essa distinção, já que imergimos nesse mundo misto, por vezes impalpável, por vezes tangível, mas igualmente, e cada vez mais, naturalmente percebido e vivenciado - um mundo tomado pelo devaneio. Nesse cenário, Pierre Lèvy acredita que um novo tipo de artista aparece. Não mais aquele que apenas conta uma história, mas "um arquiteto do espaço dos acontecimentos, um engenheiro de mundos para bilhões de histórias por vir. Ele esculpe o virtual.” (1996:148).

As obras pensadas para esse fim trabalham sobre a premissa da interação, não esperam que seu sentido se complete, pois não há um sentido específico a ser encontrado. Elas são abertas e podem se configurar de várias maneiras possíveis de acordo com as escolhas do participador. São, geralmente, pensadas sob o formato de instalação, abertas, constituídas de objetos manipuláveis, nas quais se faz o convite ao percurso, tal como se configuram algumas obras sobre as quais já discorremos aqui. Quando tratamos do diálogo entre imagens mentais e visíveis, a partir de uma postura do artista que não impõe uma narrativa, mas se comporta como um arquiteto de espaços para experiências híbridas, não podemos deixar de falar sobre Wave UFO $\left(1999\right.$ - 2002) ${ }^{125}$, de Mariko Mori ${ }^{126}$.

A artista japonesa constrói uma escultura de fibra de carbono em grandes dimensões, chegando a pesar 6 toneladas, no formato de uma gota d'água, disposta como se fosse uma nave espacial. Para adentrar a máquina, subimos por degraus que nos levam ao seu interior, onde 3 cadeiras confortáveis nos convidam a sentar e onde nos ligamos, por meio de eletrodos aderidos à cabeça, a um computador capaz de ler ondas cerebrais - nesse momento não há como não se lembrar da imagem do personagem Neo do filme Matrix (1999), que se liga a

\footnotetext{
${ }^{124}$ Segundo Flusser, as imagens técnicas constituem virtualidades concretizadas e tornadas visíveis (2008:22). O autor afirma ainda que esse tipo de imagem, a técnica, não ocuparia o mesmo nível ontológico das imagens tradicionais (2008:13).

${ }^{125}$ Disponível em < https://www.youtube.com/watch?v=Q8QbcyKwWNo $>$ Acessado em 02/05/2014. Vídeo em DVD em anexo: pasta 'Capitulo_04' $>$ 07. WaveUFO.mp4

${ }^{126}$ Mariko Mori (1967 - ) é uma artista contemporânea japonesa que trabalha principalmente com vídeo e fotografia e procura explorar os recursos tecnológicos de ponta para promover a interatividade do participador com a obra.
} 
uma máquina para entrar no mundo virtual enquanto permanence em repouso sobre uma cadeira no mundo original.

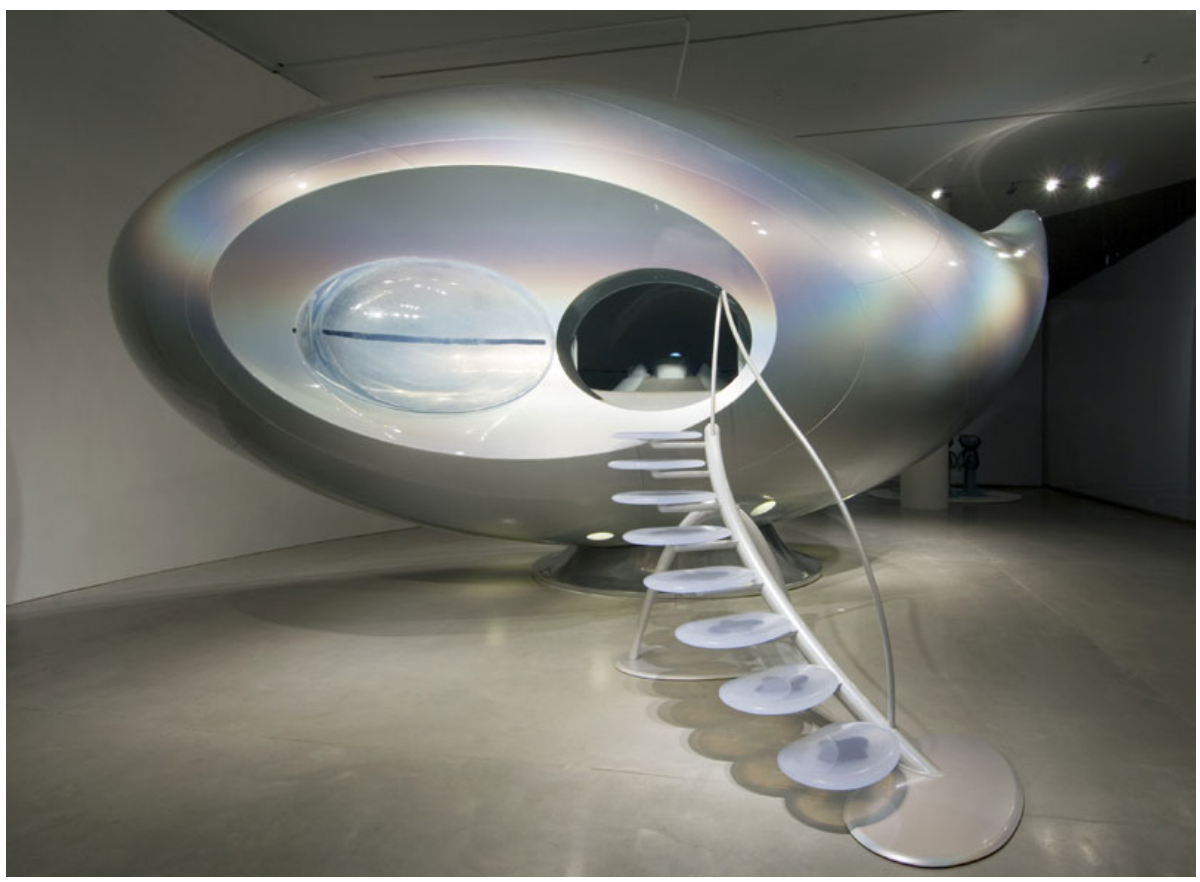

Figura 40: Nave que constitui a obra Wave UFO (1999 - 2002)

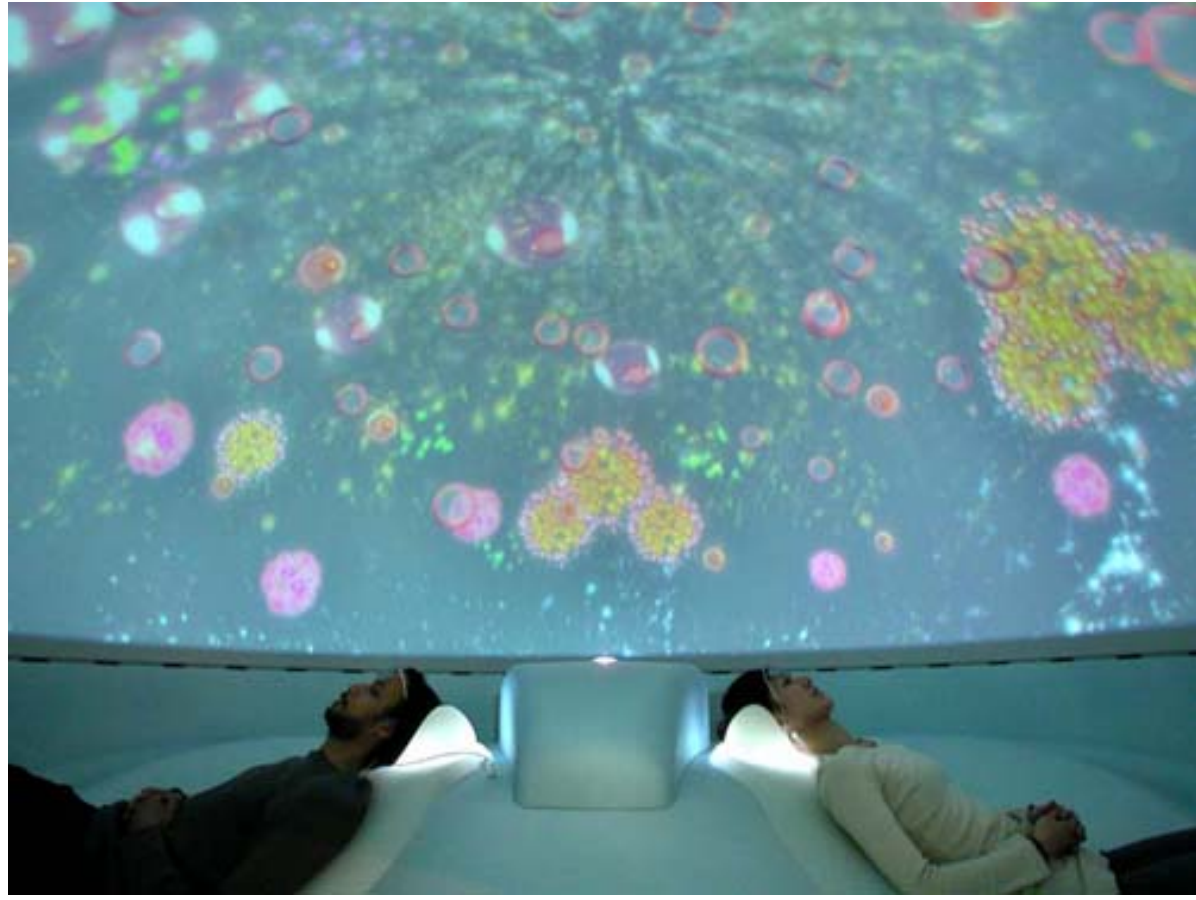

Figura 41: Interior da nave da Wave UFO (1999 - 2002) onde se desenrola a experiência

A experiência começa e vemos ser projetadas no teto da "nave" uma sequência de imagens abstratas que correspondem à leitura das ondas de nosso cérebro. Aparecem círculos 
coloridos em movimento, que aumentam e diminuem de tamanho, mudam de cor, numa sequência que nos intriga, visto ser um espelho de nossa própria mente. Na obra de Mariko Mori, a vontade de externar as imagens mentais se torna possível. Mergulhamos não na imagem, mas no fluxo de nós mesmos, conectados ao fluxo imagético-mental dos outros dois participantes. Experimentamos a sensação de flutuação.

A artista dá continuidade a sua proposta trazendo à visualização imagens de produção própria, do que acredita ser um espelho de sua relação com o cosmos, também por meio de imagens abstratas, muito semelhantes àquelas que externam nossas ondas cerebrais. Vivenciamos aí uma interconexão entre diversos mundos imaginários em que se forma um espaço de interação impalpável. Um labirinto diferente daqueles das instalações de arte contemporânea, ou seja, um labirinto mental no qual cada participante contribui para sua constituição e vivencia uma experiência diferente: visualização de um rizoma de diferentes mundos imaginários, tornada possível pela imagem técnica.

Se relacionarmos a dinâmica de geração de sentido das imagens técnicas ao conceito de mundo ${ }^{127}$ em Heidegger, encontraremos alguns pontos em comum. Para o filósofo, o mundo é constituído por uma rede de conexões que geram sentido. Como palco do ser-aí (dasein), o mundo é compreendido por meio da circunvisão, ou seja, a partir de uma percepção antinômica do mundo, em que não se faz distinção entre o sujeito e o objeto. Para Heidegger, a própria estrutura da existência é antinômica. Na medida em que o homem vê o "todo", ele se vê "essencialmente co-inserido nesse todo como algo último, experimenta seu ser-aí como estando 'envolvido' por esse medium inquebrantável, encontra-se em antinômias." (2008a:23).

Flusser, em seus ensaios, discute a imagem sob um ponto de vista fenomenológico e muitos dos conceitos usados nesse processo provêm, claramente, de um diálogo com o filósofo Martin Heidegger. Algumas ideias por ele formuladas, principalmente aquelas encontradas no livro O Universo das imagens técnicas (2008), acabam nos levando a supor uma separação entre sujeito e objeto num mundo criado por imagens. Ao afirmar que o homem dá as costas ao mundo objetivo quando imerso no onírico universo das imagens técnicas (Ibidem:135-136), Flusser questiona uma visão de mundo proposta por Heidegger, conforme expusemos anteriormente. Ora, dar as costas ao mundo objetivo é dar as costas ao mundo como todo, pois o mundo só se realiza enquanto mundo a partir da circunvisão, o que inclui a percepção tanto do sujeito como do objeto ao mesmo tempo. E o dasein só se

\footnotetext{
${ }^{127}$ Sempre que a palavra 'mundo' vier grifada em itálico é porque nos referimos ao conceito de mundo heideggeriano.
} 
realizaria como ser-no-mundo nessa dinâmica. A separação entre mundo objetivo e mundo subjetivo já incorre, portanto, na quebra do conceito de mundo heideggeriano, onde o dasein se manifesta.

Outro ponto a ser questionado: se no universo das imagens técnicas não há mais sentido na distinção entre mundo real e imaginado, por que o homem estaria dando as costas ao mundo objetivo, como propõe Flusser? Torna-se difícil pensar nesse mundo onírico das imagens técnicas justamente por seu caráter impalpável ou nulodimensional, como coloca o pensador. No entanto, Heidegger já alerta para o fato de que a concepção espacial de mundo não está ligada a questões dimensionais, mas a um estar-junto, familiarizado, habitando um mundo experienciável. Bachelard também contribui para tal ponto de vista, ao afirmar que o espaço habitado transcende o espaço geométrico (2008:62). Dessa maneira, se afastarmos a postura de tematização do mundo - que separa o sujeito do objeto —, e optarmos por uma percepção por meio da circunvisão e não da mera observação, esse mundo imagético pode constituir um palco para as experiências do dasein enquanto ser-no-mundo.

Para Heidegger, o ser-no-mundo "não diz ser dentro do mundo, mas fundamentalmente ser mundo, e isso na experiência de sendo em ser, de existir na dimensão infinitiva de ser.”(2008a:27). O ser não está dentro do mundo, o que simplificaria essa relação a uma mera questão espacial. Ser-em pressupõe que o em derive de innan - morar, habitar, deter-se. "O ente ao qual pertence o ser-em, neste sentido, é o ente que sempre eu mesmo sou [...], 'eu sou' diz, por sua vez: eu moro, detenho-me junto... ao mundo, como alguma coisa que, deste ou daquele modo, me é familiar." (HEIDEGGER; 2008a:100).

Por isso falamos em devaneio quando adentramos a dimensão dos mundos imaginários criados na relação entre estímulos visíveis e mentais, pois o espaço criado nessa dinâmica não é apenas físico, mas habitado pela experiência. Segundo Bachelard, apenas o devaneio nos ajuda a habitar o mundo: "Os mundos imaginados determinam profundas comunhões de devaneios."(2006:23). Para aquele que devaneia, o mundo que habita não se divide na dialética do sujeito e do objeto, ele está muito próximo de seu mundo, ambos estão no mesmo plano do ser, aberto aos possíveis devires: "eu sonho o mundo; logo, o mundo existe tal como eu sonho." (Ibidem:152).

Na videoinstalação Bubbles $(2000)^{128}$, de Wolfgang Muench e Kiyoshi Furukawa ${ }^{129}$, que faz parte do acervo do $Z K M$, podemos vivenciar uma situação de estarmos imersos na

\footnotetext{
${ }^{128}$ Disponível em < https://www.youtube.com/watch?v=KMZVX7DcIH8 > Acessado em 02/05/2014. Vídeo em DVD em anexo: pasta 'Capitulo_04'>> 08. Bubbles.mp4

${ }^{129}$ Wolfgang Muench (1963 - ) é artista e professor da Merz Academy em Stuttgart. Kiyoshi Furukawa (1959 - ) é músico e professor da Tokyo National University of Fine Arts and Music.
} 
imagem ao mesmo tempo em que permanecemos distanciados dela. Assim como na obra Ballet Digitallique (2010), sobre a qual falamos no capítulo anterior, aqui interagimos com as imagens técnicas por meio da projeção da nossa sombra, sozinhos ou acompanhados de outros interatores. O sistema reconhece a movimentação da imagem da sombra e permite a interação dela com as bolhas que aparecem na tela. A cada encontro entre sombra e imagem um som é emitido.

Nosso corpo observa o desenrolar da relação entre os dois tipos de imagem, mas não é um olhar passivo, pois, enquanto observamos, também manipulamos a sombra com nosso movimento. Vemos, aí, o mundo impalpável que se baseia nos algorítimos de comportamento autônomo atribuídos ao deslocamento das bolhas e que se manifesta também no transitar da sombra. Concomitantemente, temos o mundo palpável, do corpo, onde ainda se situam os aparelhos que tornam possível a realização da instalação (projetor, tela, caixas de som, etc). O espaço da experiência, então, se forma na fronteira entre real e imaginário; palpável e impalpável. No momento da vivência em si, não há distinção, ela só é possível quando habitamos o entre.

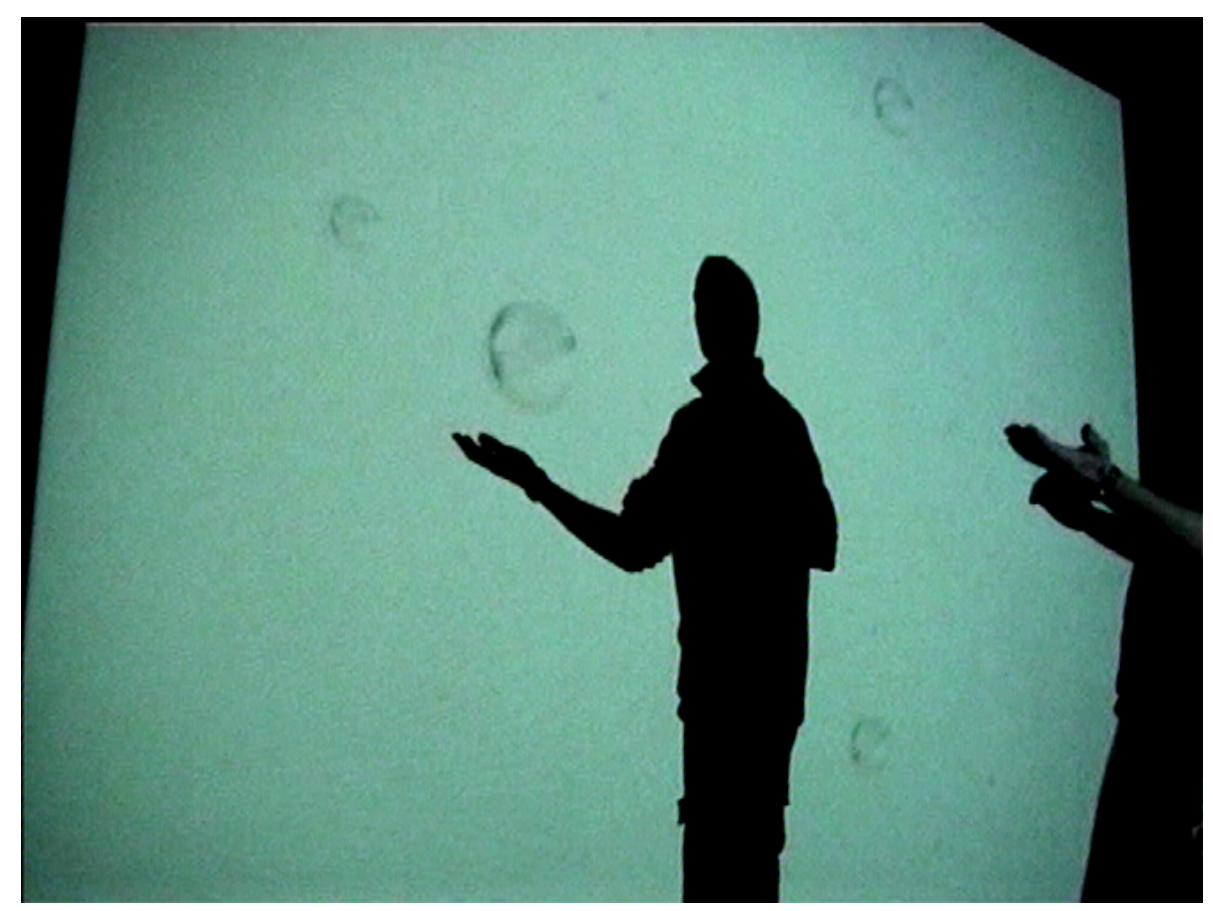

Figura 42: Bubbles (2000), Wolfgang Muench e Kiyoshi Furukawa

No filme Matrix (1999), por exemplo, podemos visualizar melhor a relação entre dois níveis de realidade, um palpável e outro impalpável. O dasein pode habitar essas duas realidades complementares, vivenciando uma e outra conforme sua vontade ou necessidade. 
Quando ligado à máquina (um sistema computacional), o ente da realidade originária (palpável) repousa fisicamente, mas continua sendo o mesmo cujo ser, por meio de imagens endógenas estimuladas pela máquina, mergulha na experiência da realidade impalpável. Essas duas realidades fazem parte do mesmo mundo do ser. No caso de Matrix, as realidades estão tão ligadas que se um personagem morre no mundo simulado e impalpável ele morre também no mundo palpável.

No momento em que isolamos apenas uma dessas realidades e passamos a considerá-la como um mundo à parte, na tentativa de compreender, a partir dela, o papel do ser na outra realidade/mundo, aí estaremos adotando a postura objetiva de tematizar uma realidade em detrimento da outra. Nessa situação realmente acabamos, como propõe Flusser, dando as costas ao mundo objetivo de onde partimos, justamente por separá-lo, isolando-o do mundo subjetivo no qual pensamos adentrar, adotando uma postura de observação (e não circunvisão) da outra realidade.

Um filme mais recente que também tem seu roteiro baseado numa situação de múltiplos níveis de realidade é Inception (2010), do diretor Christopher Nolan. Diferentemente de Matrix, a máquina geradora de realidades aqui é a própria mente humana, por meio dos sonhos. Imagens tão nulodimensionais quanto as imagens técnicas, porém geradas pelo aparelho (para usar o termo flusseriano) mais antigo de todos: o cérebro humano. Em Inception podemos distinguir claramente a inserção de uma realidade-sonho dentro da outra. A cada passagem para um novo nível de realidade, o personagem repousa no nível anterior, mas o que acontece na realidade precedente influencia aquela que está contida nela. E as experiências vivenciadas em cada nível de realidade passam a fazer parte do repertório de vivências daquele ser.

Para trazer à discussão os níveis ontológicos sobre os quais fala Flusser, devemos adotar uma postura de dis-tanciamento, como propõe Heidegger: "Dis-tanciar é, numa primeira aproximação e, sobretudo, um aproximar dentro da circunvisão, isto é, trazer para a proximidade no sentido de providenciar, apontar, ter à mão.” (2008a:159). Nesse dis-tanciar, o homem põe o mundo diante de si e o percebe como um todo a partir da imagem do mundo, ou seja, o homem compreende o mundo como imagem: "Onde se chega à imagem do mundo, cumpre-se uma decisão essencial sobre o ente na totalidade."(2002:112). Ao olhar o mundo de um ponto dis-tante, o homem se percebe como parte desse mundo e, por isso, também se concebe como imagem e como ser-no-mundo. O homem contempla, portanto, sua experiência enquanto ente, mas não de forma passiva, pois essa contemplação se dá no mesmo tempo da vivência, ou seja, ela é participativa no sentido de perceber um ente que é, sendo (no-mundo). 
Vemos que a concepção do mundo como imagem, muitas vezes por meio do devaneio, leva a um distanciamento necessário ao processo da percepção desse mundo a partir da circunvisão, levando a uma contemplação ativa que desvela o ser-no-mundo e suas vivências na abertura originária do ser quando ele, então, habita o espaço. A constituição de uma imagem de mundo é parte da própria dinâmica de compreensão da ontologia do mundo. Segundo Heidegger, quando temos a imagem de algo, a própria coisa está diante de nós (2002:112). A imagem, portanto, possibilitaria essa visão circundante que se distancia da postura tematizante e objetivadora da ciência, por exemplo.

Diante disso, retomamos a questão ontológica no que diz respeito ao universo das imagens técnicas e à dinâmica do devaneio desencadeada quando nos relacionamos com elas. Quando Flusser diz que as imagens tradicionais e as imagens técnicas ocupam níveis ontológicos diferentes, concordamos com o autor. As imagens tradicionais refletem o mundo e não criam um mundo de significados próprios, ou seja, elas se constituem enquanto coisas já pertencentes à realidade desse mundo, que apenas o reafirmam. Já as imagens técnicas, como vimos aqui, criam sentidos, geram novas conexões com outras imagens visíveis e mentais ao chamar à participação, estando-no-mundo como uma de suas possibilidades e, por sua vez, também criando novos mundos — imagem de mundo que constitui o mundo em si.

Quando Flusser afirma que, diante das imagens técnicas chegaríamos à liquidação de toda ontologia, algumas indagações nos chamam atenção. O autor diz que essa liquidação se daria devido ao fato de as imagens técnicas não ocuparem níveis de um "real", mas serem vivenciadas enquanto o concreto. No entanto, acreditamos que mesmo imerso no 'concreto' mundo onírico das imagens técnicas, o ser não deixa de estar-no-mundo. Se o tomamos isoladamente a partir desse mundo onírico, tendo ainda a consciência de um mundo do qual partiu, estaremos considerando o homem apenas como ente, que se constitui num mero objeto de observação. Quando imerso nesse mundo do devaneio, o ente vive uma experiência de sernaquele-mundo, por mais impalpável que ele seja. Além disso, mundo constituído como imagem, como já afirmamos tantas vezes, não deixa de ser mundo.

Flusser ainda diz que, nesse contexto, passaríamos de um estar-no-mundo a um estarface-às-imagens. No entanto, a postura de estar face às imagens pode levar a uma má compreensão de um contemplar passivo dessas imagens, enquanto o homem se percebe como estando fora delas para observá-las e não dis-tante, numa dinâmica de circunvisão, como propõe Heidegger. Nesse caso, não haveria vivência, mas controle, pelas imagens, das experiências de mundo do homem, que se deixaria levar passivamente. 
Estar-face-às-imagens pressupõe um comportamento que nos remete ao homem que habita a caverna de Platão. No universo das imagens técnicas podemos ser criadores além de espectadores; criadores de mundos que podem ser virtuais ou oníricos mas que não deixam de ser reais e que se relacionam às percepções e recordações pessoais de seu criador - um serem-seu-mundo. Pierre Lèvy afirma que a virtualização não é uma desrealização, mas "uma mutação de identidade, um deslocamento do centro de gravidade ontológico do objeto considerado [...] A virtualização é um dos principais vetores de criação da realidade."(1996:17-18).

O mundo virtual da internet, bem como os mundos criados pelas imagens técnicas e mentais são, também, mundo. Desvinculados de uma questão dimensional do espaço e cronológica do tempo, são palco para o compartilhamento de experiências e vivências, o que nos remete ao que Heidegger fala sobre o ser-no-mundo ser, também, um ser-com os outros. “À base desse ser-no-mundo determinado pelo com, o mundo é sempre mundo compartilhado. O ser-em é ser-com os outros.” (2008a:175). É assim que Lèvy acredita que se atualiza o virtual, por meio da experiência ou dos afetos, na implicação recíproca entre uma subjetividade e seu mundo (1996:108).

O sucesso de algumas redes sociais e aplicativos móveis é um forte exemplo de atualização de afetos entre pessoas que se encontram no ciberespaço, desterritorializadas, mas que querem habitar esses lugares virtuais de estabelecimento de laços sociais. Apesar de sempre estarmos em movimento, também estamos constantemente em busca de conexões com o outro. O projeto Geopartitura $(2013)^{130}$, desenvolvido pelo MídiaLab ${ }^{131}$, laboratório de pesquisa em arte computacional da Universidade de Brasília e coordenado pela professora Suzete Venturelli, aponta para essas questões, ao procurar articular pessoas em lugares distintos permitindo a criação coletiva de um concerto multimídia em tempo real por meio do uso de celulares e da tecnologia de georreferencialmento (GPS).

Ao conectar-se ao sistema, o usuário pode observar uma imagem em forma de rede. A esfera que está no centro dessa rede se refere ao posicionamento de quem está utilizando o aplicativo e as outras esferas coloridas representam a posição dos demais usuários, captada por GPS. As esferas são ligadas por linhas que funcionam como cordas de um instrumento musical, que pode ser tocado em conjunto e à distância. Ao tocar em cada uma das esferas, a corda que liga o centro da rede a ela vibra e emite um som, daí poder-se falar de um concerto

\footnotetext{
${ }^{130}$ Disponível em < https://www.youtube.com/watch?v=ZOIg2O0L10M > Acessado em 02/05/2014. Vídeo em DVD em anexo: pasta 'Capitulo_04'> 09.Geopartitura.mp4

${ }^{131}$ Site do laboratório: <http://www.midialab.unb.br/>
} 
multimídia, pois vemos o som por meio da vibração e movimento das cordas e da rede. Temos aí um rizoma que permite visualizar os elos sociais que se estabelecem entre pessoas que se encontram em lugares distintos mas que, na rede, se encontram, formando uma topologia imaginária que repercute em imagem, som e movimento.

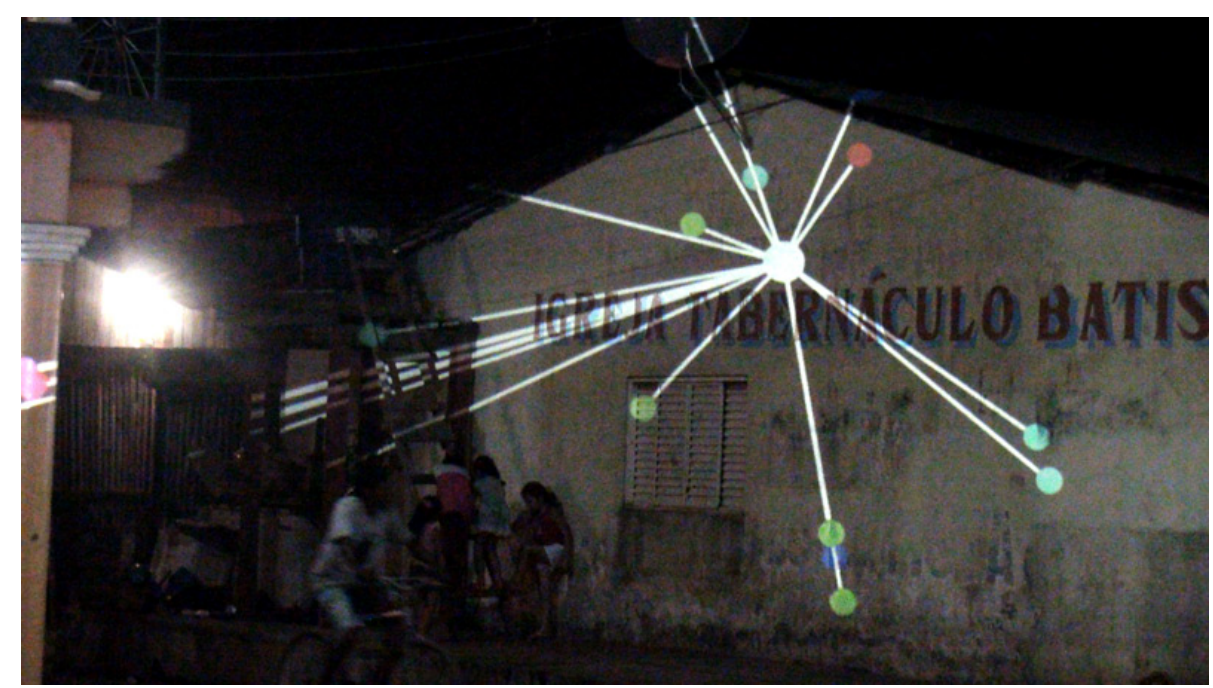

Figura 43: Geopartitura (2013), MidiaLab UnB

Vemos então que, no universo das imagens técnicas, podemos conceber vários aspectos dessa relação do ser-com o mundo que parecem se tornar ainda mais perceptíveis que antes o que não quer dizer que antes eles não existissem. Nesse contexto, e diante das considerações que levantamos até aqui, cremos poder afirmar que o universo das imagens técnicas é caracterizado pelo mundo significado por essas mesmas imagens, criando o palco para uma possível manifestação do dasein, que o habita mediante a vivência e compartilhamento de suas experiências. Ou seja, nos referimos a um mundo constituído pelo devaneio, posto que híbrido entre imagens visíveis e mentais e ainda permeado da consciência da percepção. Segundo Bachelard, para a fenomenologia da imaginação devemos viver diretamente as imagens e considerá-las como acontecimentos súbitos da vida: "quando a imagem é nova, o mundo é novo."(2008:63).

Arriscamos dizer que, para além de estarmos face-às-imagens como propõe Flusser, no universo das imagens técnicas nós estamos-nas-imagens. Nesse sentido, concebemos um mundo onde é possível habitar uma vida dupla entre real e imaginário, pois não há mais razão de se pensar a distinção entre eles. Quem habita esse mundo é o homem do devaneio, que aí está em toda parte, num dentro que não tem fora: “O mundo já não está diante dele [...] tudo 
é acolhimento.” (BACHELARD;2006:161). Não é à toa que se costuma dizer que o sonhador está imerso no seu devaneio.

\subsection{Imersão e experiência: o ser-em remete ao ser-com}

A sensação de imersão surge principalmente nos espaços virtuais em função de sua forma tridimensional na qual é possível também interagir com o ambiente, outras pessoas e objetos. Nas obras de artemídia, segundo aponta Suzete Venturelli, esse sistema acaba se reforçando na abertura a três possíveis processos de criação: a desmaterialização da imagem, a interatividade em seu modo dialógico e a escrita da imagem (2011:65). Nas instalações artísticas que abordamos aqui encontramos o apelo ao recurso da projeção, bem como à luz, que procuram transmitir essa ideia de imagem impalpável percebida como não material e possível não apenas de se moldar ao ambiente visível mas também de moldar um ambiente próprio, intensificando a sensação de imersão em espaços virtuais. Tais imagens, digitais em sua natureza, requerem um conhecimento da escrita da imagem, mas não de forma purista e, sim, na relação com outras linguagens para completar seu sentido, formando um todo híbrido. Além disso, a questão da interatividade, como propõe Suzete Venturelli, dialogando com o pensamento de Anne Shillingri, deve ser melhor compreendida. Enquanto o termo interação se relaciona a uma troca pontual e automática entre duas entidades, a interatividade quer dizer um conjunto de relações (2011:76) - situação mais adequada às plataformas híbridas e multimídia sobre as quais estamos falando.

Lembremos da obra Legible City (1988-1991) ${ }^{132}$, de Jeffrey Shaw ${ }^{133}$, que hoje faz parte do acervo do $Z K M$, em Karlshue. O artista desenvolveu, sobre os mapas de Amsterdam, Nova Iorque e Karlshue, uma representação de cada uma dessas cidades a partir de letras tridimensionais que formam palavras e frases ao longo das ruas. Diante da tela se encontra uma bicicleta, sobre a qual subimos para interagir com a obra. Podemos manipular a velocidade dos pedais e o direcionamento da bicicleta, controlando, assim, nosso percurso dentro das cidades virtuais criadas por letras e reafirmando a ligação entre a ação corporal que exercemos no "mundo real" e a atividade que se desenrola no "mundo virtual". Shaw nos convida a uma viagem nesse espaço em que escolhemos o sentido da leitura, dependendo dos caminhos que traçamos. A relação entre os dois espaços, o real e o virtual cria uma sensação

\footnotetext{
${ }^{132}$ Disponível em < https://www.youtube.com/watch?v=6117Y4MS4aU > Acessado em 12/05/2014. Vídeo em DVD em anexo: pasta 'Capitulo_04'>>10. LegibleCity.mp4

${ }^{133}$ Jeffrey Shaw (1944 - ) é um dos artistas pioneiros da arte virtual e interativa desde o final da década de 1960. Site do artista: < http://www.jeffrey-shaw.net/html_main/frameset-explore.php >
} 
de imersão que se intensifica pela interatividade com a obra, no sentido plural e híbrido, como afirma Anne Shillingri, já que estamos diante de uma instalação que congrega não apenas um hibridismo de linguagens, mas também de técnicas e possibilidades.

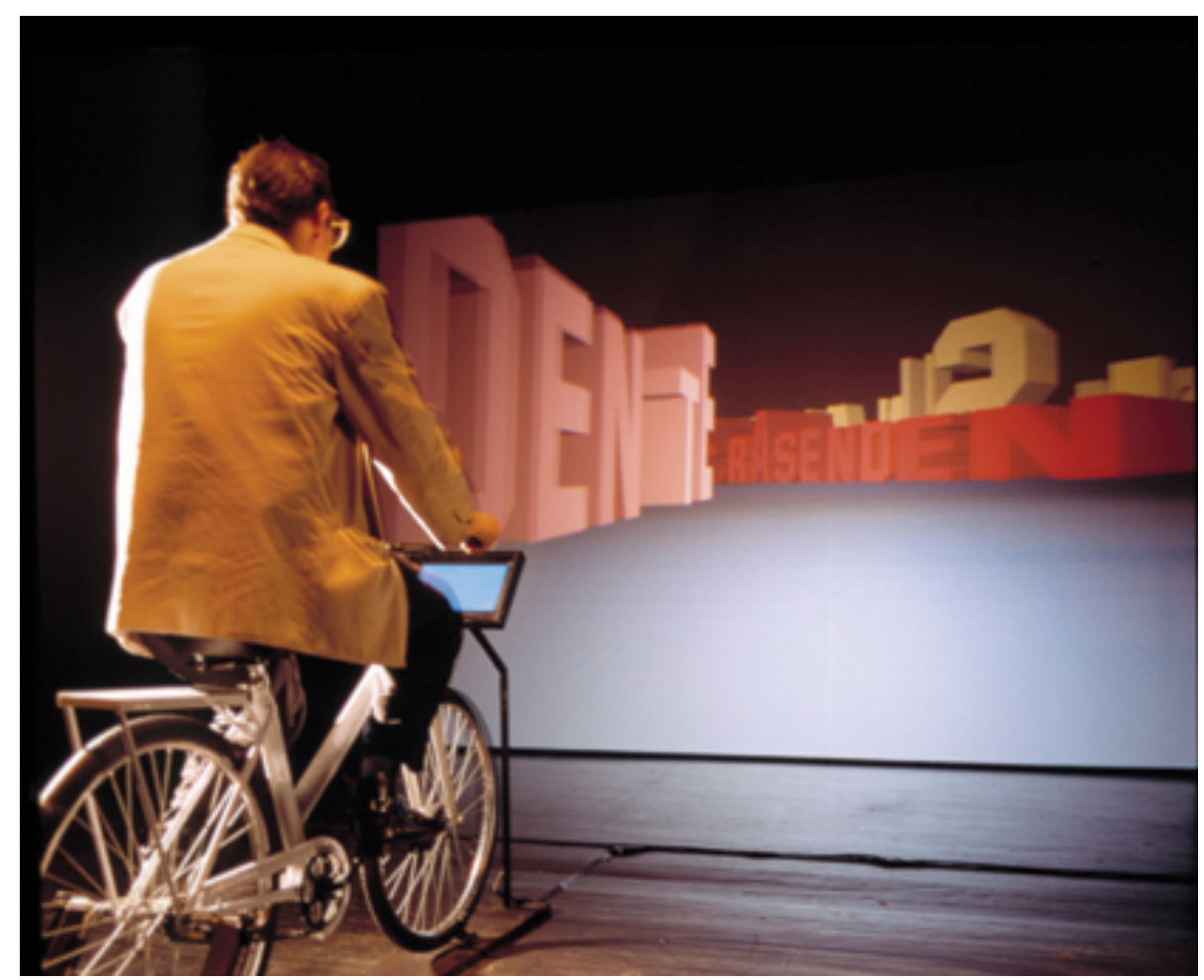

Figura 44: Legible City (1988-1991), Jeffrey Shaw

Vemos como as obras de artemídia acabam não apenas por oferecer os elementos para a criação de uma sensação de imersão, mas também se baseiam nesses elementos como própria forma de se constituírem. A imersão faz parte da experiência. No entanto, não é apenas graças à tecnologia digital ou ao desenvolvimento de plataformas multimídia e $3 \mathrm{D}$ que podemos vivenciar tais situações. Oliver Grau, em seu livro Virtual art. From illusion to immersion (2003) discute exemplos de técnicas imersivas desde o período antes de Cristo. Um dos exemplos que ele dá é o da Villa dei Misteri em Pompeia (60 a.C. circa), onde um afresco com figuras em grandes dimensões de pessoas em um ritual toma as quatro paredes de um espaço, preenchendo-a com imagens, dando a sensação de fazermos parte do mesmo ambiente delas: "o efeito mais importante é o de totalidade; é uma imagem que se dirige ao observador de todos os lados." (2003:25). Outro exemplo é o de Villa Livia (20 a.C. circa), em Primaporta, Roma, que cria a ilusão de um jardim artificial. Além das imagens panorâmicas, da ausência de molduras, da correta escolha das cores, o autor destaca como a imagem se relaciona ao espaço da sala que a recebe e até mesmo à entrada de luz no ambiente, que 
ilumina tanto o afresco quanto o observador. Dá-se uma transposição de lugares, de uma sala a um jardim, como também o faz Kátia Maciel em sua obra À sombra (2011), nos conduzindo numa viagem imaginária ao Jardim Botânico do Rio de Janeiro, como mostramos anteriormente.

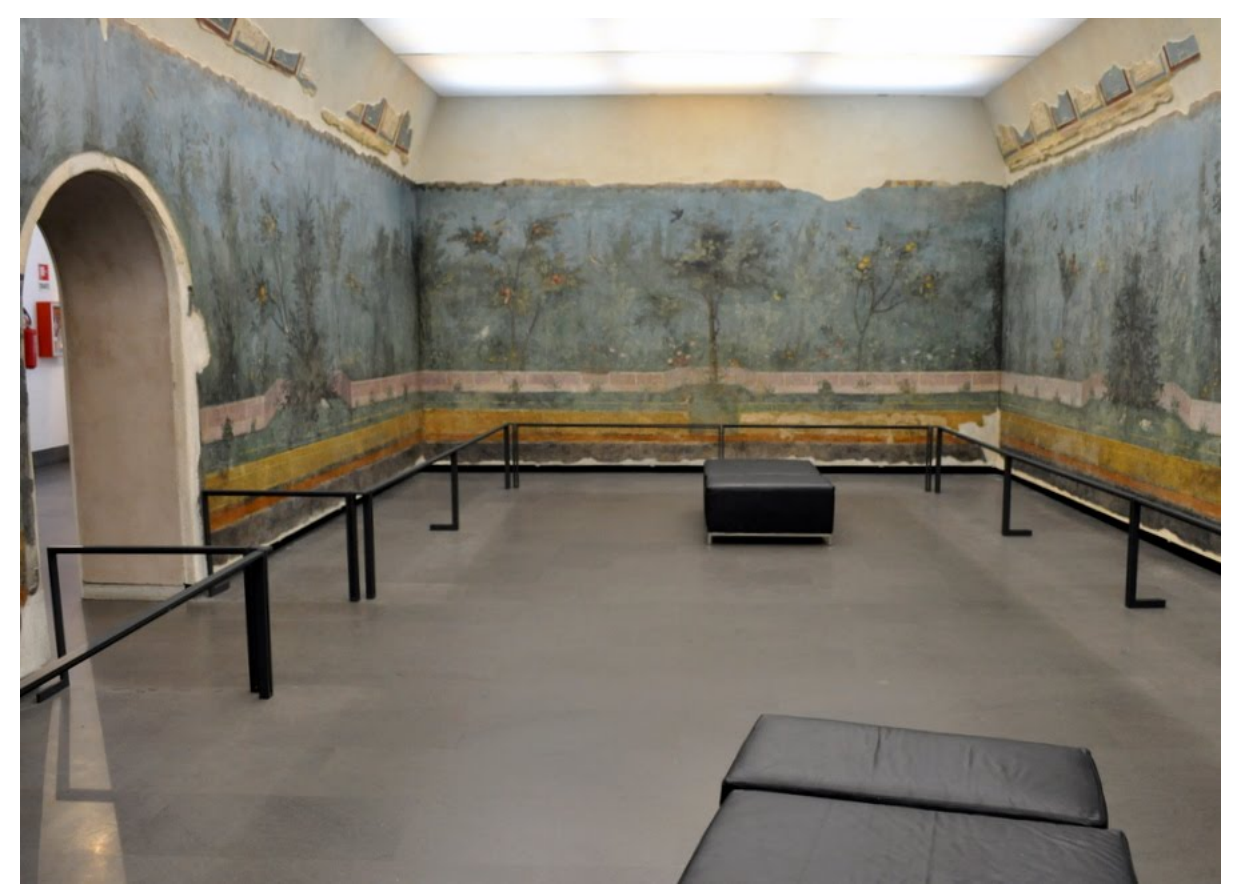

Figura 45: Vila Livia (20 a.C. circa)

A imersão não deixa de ser uma ilusão que joga com a percepção e os sentidos, criando uma virtualidade que não é necessariamente digital ou multimídia, mas também imaginária. De acordo com Oliver Grau, num espaço virtual os parâmetros de espaço e tempo podem ser modificados e as imagens do mundo natural podem se mesclar com imagens artificiais, formando uma realidade mista em que não se torna mais possível distinguir entre o original e o simulacro - assim como acreditamos acontecer nas obras de artemídia, nas quais não há sentido em fazer tal distinção. Segundo Eduardo Kac, artista que tem se dedicado a pesquisas envolvendo realidades virtuais, a "realidade virtual mistura as ideias de corporeidade tangível (real) e representação intangível (virtual). Para experimentar a realidade virtual, deve-se, em certo sentido, entrar na imagem virtual; deve-se estar imerso no ciberspaço. Esses dois conceitos são inextricáveis."134 (KAC,1993)

\footnotetext{
${ }^{134}$ KAC, Eduardo. Telepresence in art. Disponível em: http://www.ekac.org/telepresence.art._94.html. Acessado em 12/05/2014. Originalmente publicado em inglês e em alemão na Teleskulptur, Richard Kriesche, Editor (Graz, Austria: Kulturdata, 1993), pp. 48-72. Uma versão resumida foi publicada em "Telepresence: A New Communicative Experience", Epipháneia, N. 2, March 1997, Salerno, Italy, pp. 53-55.
} 
A cada época o homem soube se utlizar das técnicas disponíveis para criar essa sensação de imersão, seja com a perspectiva renascentista ou com o dinamismo e o volume barroco, como podemos ver tanto na Sala delle Prospettive (1519), de Baldassarre Peruzzi (1481 1536), na Villa Farnesina, em Roma, como nos afrescos de tetos de tantas igrejas adornadas por Andrea del Pozzo (1642 - 1709), respectivamente. Tanto no presente quanto no passado, a imersão se caracteriza por ser um processo estimulante, em que há passagem de um estado mental a outro, diminuindo a distância crítica ao que é mostrado e aumentando o envolvimento emocional com o que está acontecendo (POPPER;2007:190). A partir desse envolvimento, somos capazes de transitar entre realidades diferentes, sejam elas reais ou virtuais, palpáveis ou impalpáveis ou ainda visíveis ou mentais. Grau afirma que recentes pesquisas no campo na neurobiologia propõem que o que chamamos de realidade seria apenas uma indicação sobre o que na verdade somos capazes de observar (2003:17), daí a importância de trazermos considerações relativas à percepção e às sensações despertadas nas dinâmicas perceptivas para compreender tais processos.

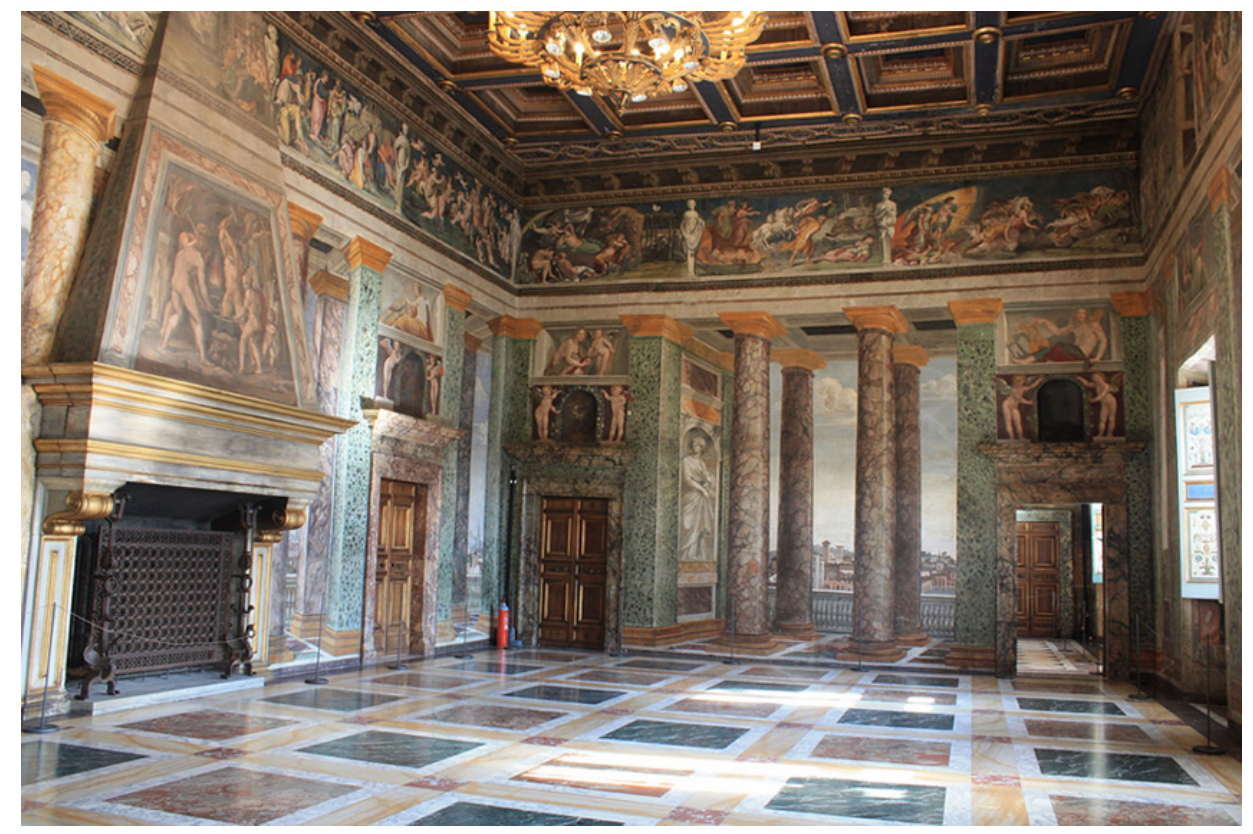

Figura 46: Sala delle Prospettive (1519)

Os exemplos que trouxemos logo acima se utilizam, basicamente, de técnicas próprias da pintura, além de dialogar com a posição do observador (situado sempre no centro da imagem), aspecto importante para criar a sensação de imersão. A partir do século XIX, com o surgimento dos panoramas, conhecemos uma técnica híbrida, em que se misturam técnicas de arquitetura, teatro e pintura para aumentar tal sensação. Os panoramas se apresentam como 
um quadro de grande formato na disposição de um semicírculo, acompanhando o formato do próprio prédio onde estão instalados, muitas vezes construídos especialmente para sua exposição. Tal como se dá na obra de artemídia contemporânea, o visitante adentra o panorama por uma passagem escura que leva à plataforma onde se pode visualizar a imagem, amplamente iluminada. Muitos deles eram observados a partir de tablados elevados do chão, para que se tivesse maior abrangência da dimensão da tela, dependendo da perspectiva escolhida para realizar a imagem. Num primeiro plano, entre o espectador e o painel, se interpunham objetos relativos ao tema da pintura, criando uma espécie de cenário que aumentava a sensação de profundidade e realismo.

Um exemplo de panorama de grande repercussão foi o realizado para representação de uma cena da Batalha de Sedan, travada durante a guerra franco-prussiana em 1870, para fins nacionalistas, encomendada inicialmente pelo governo alemão. A execução da obra foi planejada por Anton von Werner $(1843$ - 1915), mas exigiu um trabalho em conjunto de fotógrafos, desenhistas, pintores, artesãos, carpinteiros e serralheiros, deixando clara a característica híbrida e a estrutura industrial necessária para sua viabilização. Também as famosas Nymphéas (1895-1923) de Claude Monet (1840 - 1926), expostas no Musée de l'Orangerie em Paris, são um exemplo de imagem composta de várias telas à óleo, bem iluminadas, dispostas em dois salões ovais que englobam o espectador no centro, criando um ambiente propício à imersão.

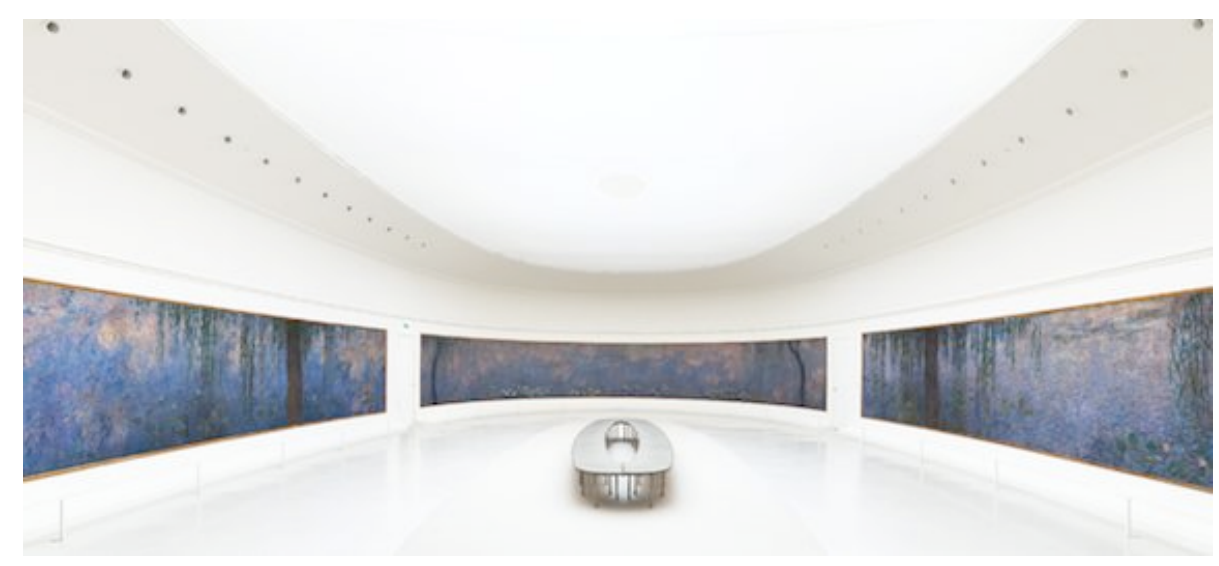

Figura 47: Uma das salas do Musée de l'Orangerie

Assim como se dá no panorama, também nas instalações de artemídia o ambiente físico serve como palco onde outro espaço ganha destaque: aquele vivenciado, da experiência, que só existe na duração. Esse, sim, pode ser um espaço real, virtual ou misto. $\mathrm{Na}$ contemporaneidade, devido às tecnologias digitais, essa dinâmica se intensifica, tendo em 
vista que a própria imagem é percebida como imaterial quando transita e quando se manifesta, se desterritorializando por meio de códigos binários que viajam nos cabos ópticos de computador a computador em diferentes lugares do planeta: fluxo de informação que se virtualiza em números e se atualiza em imagem. Muitas vezes, também nós desejamos viajar com os códigos e entramos na dinâmica de virtualização/atualização quando escolhemos um perfil, um avatar ou qualquer outro tipo de representação em rede.

Há algumas décadas não só artistas, mas também a indústria da tecnologia e da computação têm buscado formas de tornar possível a transformação de nossos corpos em fluxo de informação, minimizando a dependência das próteses e indo em direção ao que McLuhan, já na década de 1960, dizia sobre os meios de comunicação serem extensões do homem. No campo da artemídia, podemos citar o trabalho do brasileiro radicado nos Estados Unidos, Eduardo $\mathrm{Kac}^{135}$. Ele tem trabalhado o conceito de telepresença para experimentar com a imersão em ambientes virtuais, principalmente em tempo real, via internet. Essa situação permite que os participantes, além de vivenciarem a imersão, também realizem o processo em conjunto, de forma desterritorializada e em contato com vários outros usuários concomitantemente, tendo a sensação de realmente viajarem pela rede, pois os comandos que realizam atrás do monitor acarretarão em ações que ocorrem em outro lugar. Além disso, pela telepresença, busca-se, segundo Kac, chegar a um meio em que exista equivalência entre a experiência robótica e a humana, chegando ao ponto em que as características antropomórficas do robô sejam equivalentes às nuances dos gestos humanos (KAC,1993) ${ }^{136}$.

Dentre as várias obras de Eduardo Kac que se voltam à telepresença, citamos a instalação Teleporting an Unknown State (1994-1996) ${ }^{137}$, em que uma planta é disposta em um pedestal de madeira situado em completa escuridão. Existe uma fonte de luz no mesmo ambiente que está apontada para o pedestal mas que é acionada apenas remotamente, via web, permitindo que um comando realizado por qualquer usuário em alguma parte do planeta se transforme em uma ação que permita a realização de fotossíntese e consequente crescimento da planta na sala da exposição. A luz enviada também provém de lugares diversos. O artista instalou quatro câmeras espalhadas pelo mundo, em lugares distintos como Nova Iorque, Rio de Janeiro, Tóquio, Cidade do Cabo (entre outros, dependendo da versão da exposição). Essas câmeras estão apontadas para o céu, captando a luz solar. Quando o usuário interage com a

\footnotetext{
${ }^{135}$ Eduardo Kac $(1962-)$. Site do artista: < http://www.ekac.org/ >

${ }^{136}$ KAC, Eduardo. Telepresence in art.Disponível em: < http://www.ekac.org/telepresence.art. 94.html>. Acessado em 12/05/2014. Originalmente publicado em inglês e alemão na revista Teleskulptur, Richard Kriesche, Editor (Graz, Austria: Kulturdata, 1993), pp. 48-72

${ }^{137}$ Disponível em < https://www.youtube.com/watch?v=sD3rbN_9D2E > Acessado em 12/05/2014. Vídeo em DVD em anexo: pasta 'Capitulo_04'>> 11.TeleportingAnUnknownState.mp4
} 
interface, ele escolhe de qual lugar quer que se origine a luz que irá nutrir a planta. Também em Rara Avis (1996), Kac trabalha o conceito de telepresença ao instalar uma arara robótica dentro de um aviário, cujos olhos são câmeras e a cabeça se move de acordo com os movimentos do participador, que usa um headset, sendo este o aparelho que permite coincidir seus movimentos com os da arara, levando o usuário a ter a visão do ponto de vista do robô, dentro da gaiola.

Vemos em ambos os casos que a investigação artística por trás das obras busca, por meio da imersão e da indiscernibilidade entre mundo visível e virtual, criar uma sensação híbrida de um corpo que não precisa se prender à materialidade da carne, mas viaja pela rede, dialoga com outros participantes, dividindo experiências controladas remotamente. No entanto, percebemos que a necessidade do aparelho ainda é predominante e, por mais que tenhamos experiências de desterritorialização promovidas por um bom domínio das técnicas de imersão, ainda não chegamos ao ponto de coincidência total entre homem e máquina. Mesmo assim, devido a nossa origem grego-judaico-cristã ocidental, que não nos permite dissociar facilmente imaterialidade da espiritualidade (WERTHEIM;2001:189), quando nos vemos mergulhados no ciberespaço por meio da representação de imagens-avatares, acabamos nos inserindo nesse fluxo em que tudo é um, onde podemos fazer upload de nossas mentes e deixar pra trás as limitações do corpo.

Por mais que ainda dependamos da máquina para vivenciar tais experiências, não temos dificuldade em habitar o espaço do imaginário, ou o espaço híbrido entre real e virtual, entre visível e mental. É natural, portanto, que, ao vivenciar uma experiência por meio de imagens virtuais, nosso corpo se comprometa e sofra as sensações despertadas pela percepção mista, ampliando a consciência da imersão. Nesse novo paradigma, o usuário não se encontra mais frente ao monitor, mas, sim, dentro da interface tal como nos filmes de ficção científica, por exemplo, Tron (1982), de Steven Lisberger e o Passageiro do Futuro (1992), de Brett Leonard. Suzete Venturelli afirma que, em entrevista a um de seus orientandos, João Bosco de Aquino, Roy Ascott vislumbrou um futuro em que as interfaces serão multifísicas e não haverá a necessidade de se estar diante de um monitor, pois o computador será uma inteligência que é parte de nós mesmos (2011:113).

O paradigma de construção e fruição da imagem com o qual estamos acostumados hoje, apresentado em formato retangular numa superfície plana, se amplia e ganha todas as dimensões numa relação com sensações outras que apenas a visual, envolvendo uma dinâmica corporal muitas vezes desterritorializada e imaterial, intensificando ainda mais o aspecto da experiência. Lev Manovich, em seu livro The language of new media (2001), vislumbra o 
desaparecimento da tela (2001:101), no entanto, ele aponta para o fato de que a tecnologia da realidade virtual ainda não conseguiu romper por completo com a dependência da prótese maquínica. Por mais que já se permita o deslocamento e mobilidade do observador, ele ainda precisa atrelar uma máquina ao corpo para vivenciar tal experiência.

Para Manovich, a realidade virtual se insere mais na escala da simulação do que representação, no sentido de que, quando falamos em representação, permanecemos no âmbito do mundo humano e, consequentemente, falar de real e virtual nos leva a pensar espaços contínuos. Já quando se fala em simulação tende-se a mesclar os espaços físicos e virtuais ao invés de separá-los (2001:112). Baudrillard também vai distinguir a noção de representação da de simulação. No primeiro caso, segundo o autor, trabalhamos com dinâmicas de equivalência do signo e do real, tentando absorver a própria simulação e interpretando-a como falsa. Nesse sentido, seja a imagem um reflexo da realidade ou que tente mascará-la ou ainda deformá-la, permanece na esfera representacional. A simulação, por sua vez, parte da negação radical do signo como valor, aniquilando a referência real e assumindo o simulacro. A imagem da simulação não tem relação com qualquer realidade, ou seja, ela é seu próprio simulacro e por isso também permite o diálogo criativo entre os dois mundos (1991:13). Daí afirmarmos que não há sentido, cada vez mais, em fazer a distinção entre visível e mental ou real e virtual.

Baudrillard se aprofunda ainda mais nesse caminho ao reforçar que essa indistinção nos leva a perceber que não existe, portanto, o real mas sim o hiper-real, que englobaria várias possíveis dimensões, tanto materiais quanto mentais (1991:30). Edmond Couchot chama atenção para o fato de que nesse ambiente hiper-real, sobre o qual falamos, a imagem não se interpõe mais entre objeto e sujeito, mas se torna o lugar onde se dá o encontro entre os dois. Dessa maneira, a imagem só existe na relação com o sujeito e com o objeto, gerando entidades híbridas e não hierarquizadas, em constante transformação, seguindo o fluxo da experiência. Essas podem ser meio sujeito/meio objeto, ou meio imagem/meio sujeito ou ainda meio imagem/meio objeto (1998:157).

As VideoCriaturas do artista brasileiro Otávio Donasci ${ }^{138}$ podem bem ser representantes dessa dimensão hiper-real e híbrida tanto de linguagens quanto de realidades. Criadas na década de 1980, elas são meio homem, meio máquina e resultam do diálogo entre vídeo, teatro, dança, performance e instalações multimídia, gerando uma interação ao vivo. Eram

\footnotetext{
${ }^{138}$ Otávio Donasci (1952 -). "Profissionalmente cenógrafo de teatro e produtor de eventos especiais, celebrizou-se no terreno da arte-tecnologia pelo seu projeto do videoteatro, primeiramente por meio de suas videocriaturas e posteriormente com de suas performances multimídia "(Disponível em: $<$ http://www.cibercultura.org.br/tikiwiki/tikiindex.php?page $=\mathrm{Ot} \% \mathrm{C} 3 \%$ A1vio+Donasci $>$. Acessado em 10/09/2014)
} 
compostas por um ator que, ao invés de apresentar sua própria face, exibia um monitor de TV no lugar da cabeça que mostrava rostos diversos recitando monólogos ou dialogando ao vivo com o público. Para a exposição @rtOutsiders: Brasil Digital, realizada em 2005 na Maison Européenne de la Photographie em Paris e dedicada especialmente à artemídia brasileira, Donasci desenvolveu uma versão de suas videocriaturas: VideoCriatura Imersiva $(2005)^{139}$.

Nela, o ator usava um capacete com um visor, que convidava o participador a olhar através dele, entrando em contanto com o vídeo de uma personagem feminina cuja proposta era conduzir o participante numa viagem por paisagens e elementos da cultura brasileira. Enquanto visualizava o vídeo, o participador era conduzido pelas calçadas da cidade onde estava efetivamente, enxergando apenas o que a tela lhe mostrava. Um percurso que se dava visualmente e mentalmente mas que se completava com o deslocamento real. Além disso, a cada estímulo sugerido pelas imagens, uma equipe que acompanhava o ator e o participador, realizava pequenas ações sensoriais que intensificavam as sugestões visuais, como borrifar água e abanar uma espécie de leque quando se mostravam imagens de praia, ou ainda oferecer uma banana de verdade quando a personagem o fazia no vídeo, entre outras sensações e estímulos. Aí temos um caso em que a presença do capacete como aparelho ou prótese se coloca de forma muito evidente, no entanto, a indiscernibilidade entre as sensações de real e virtual se intensifica devido às experiências sensoriais que acompanham a performance. $\mathrm{Na}$ verdade, o que acontece aí é que as experiências palpáveis, realizadas no contato com o corpo acabam por tornar mais "reais" as sugestões do vídeo, fazendo com que se assuma uma imaterialidade do corpo que imerge na imagem e se transporta para a situação aí sugerida.

\footnotetext{
${ }^{139}$ Disponível em < http://vimeo.com/25367157 > Acessado em 12/05/2014. Vídeo em DVD em anexo: pasta 'Capitulo_04>> 12.VideoCriaturaImersiva.mp4
} 


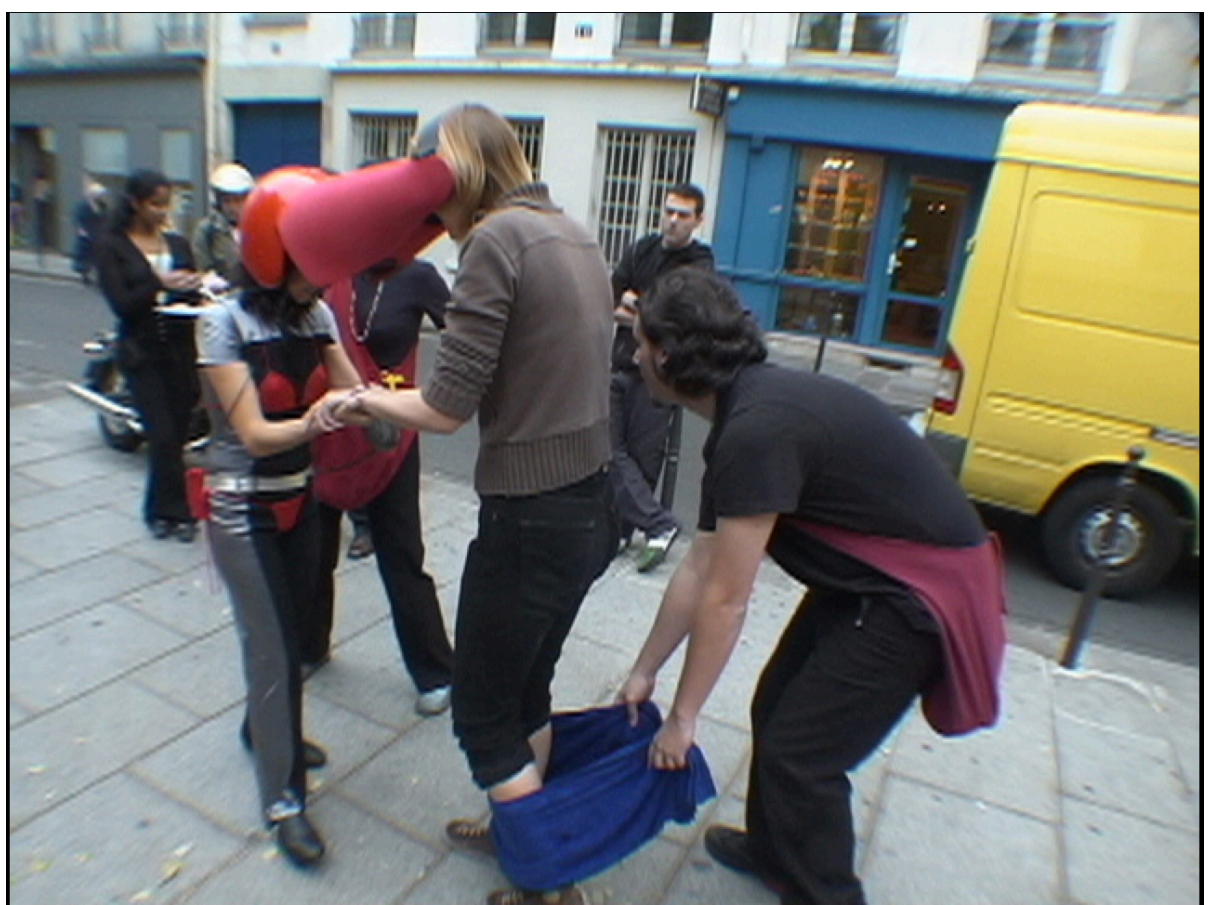

Figura 48: Vídeo-performance VideoCriatura Imersiva (2005), Paris, Otavio Donasci

Para Oliver Grau, não há como vivenciar esse universo híbrido entre real e virtual senão por meio da imersão ou da impressão estética da imersão (2003:201). Adentramos o reino do mental no qual, segundo David Le Breton, se dá todo o poder ao pensamento: "Imaterial, o sujeito se reduz estritamente às informações que ele fornece, ele encarna um cogito puro" (2013:149). Aí, de acordo com o autor, vivemos numa espécie de sonho acordado — ou de devaneio, para retomar o pensamento de Bachelard - em que uma variedade de mundos e de formas de encarnação virtual são possíveis, não atreladas ao princípio de realidade mas sob a égide do prazer e do imaginário (LE BRETON;2013:150)

Oliver Grau complementa seu pensamento acerca da imersão ao dizer que, se no ambiente virtual, além da sensação libertária de experimentar a imaterialidade, ainda nos depararmos com interações sociais - por meio de criaturas artificiais e agentes que reajam aos observadores ou ainda com outros personagens e avatares de participantes desterritorializados que habitam a mesma virtualidade - , a sensação de imersão e de estar no espaço da imagem se intensifica ainda mais, assim como acontece na performance VideoCriatura Imersiva (2005). Ora, essa dinâmica reforça o que temos falado até aqui sobre a cada vez maior naturalização da percepção de uma realidade mista na qual não há distinção entre o real e o virtual, na qual habita-se o imaginário e a simulação.

Vemos, portanto, que a experiência estética na imersão se intensifica quando compartilhada, ou seja, habitar (ser-em) o virtual se relaciona também a uma dinâmica que 
leva a buscar o outro que, por sua vez, também vivencia a experiência (ser-com). Para Michel Maffesoli, vivemos numa época em que as emoções constituem o cimento próprio do estarjunto (2012:37). O autor ainda reflete sobre o papel da tecnologia nessa dinâmica ao afirmar que o desenvolvimento tecnológico, que inicialmente tinha participado da "desmagificação" do mundo, contribuindo para o isolamento dos indivíduos, assume agora o papel contrário, contribuindo para uma nova ligação: a do estar sempre em contato. Nenhuma novidade se pensarmos no sucesso das plataformas de redes sociais que promovem justamente a criação e fortalecimento de laços em rede em ambientes virtuais que ganham dimensões e importância de ágoras da contemporaneidade. As sensações despertadas pela experiência nessas relações servem como elo de coexistência ou de comunhão, como propõe Merleau-Ponty, pois toda sensação comporta um germe de sonho ou de despersonalização que nos remete a uma dimensão maior que nós mesmos, na qual encontramos o outro (1999:288-290).

Toda vez que experimento uma sensação, sinto que ela diz respeito não ao meu ser próprio, aquele do qual sou responsável e do qual decido, mas a um outro eu que já tomou partido pelo mundo, que já se abriu a alguns de seus aspectos e sincronizou-se a eles. Entre minha sensação e mim há sempre a espessura de um saber originário que impede minha experiência de ser clara para si mesma. Experimento a sensação como modalidade de uma existência geral, já consagrada a um mundo físico, e que crepita através de mim sem que eu seja seu autor (MERLEAU-PONTY;1999:291)

Assim, ao vivenciar a experiência estética como uma 'existência geral', percebemos as sensações que daí derivam como aglutinadoras de elementos díspares, remetendo-nos ao sem fundo de um saber originário, tal como afirma Merleau-Ponty. Dá-se, aí, uma dinâmica que se enraíza profundamente, segundo Michel Maffesoli, tanto na matéria individual quanto coletiva e permite compreender "as surpreendentes agregações sociais, os encontros afetivos, as afinidades eletivas, as correspondências naturais, numa palavra, a sensibilidade 'ecológica' da qual não se pode negar a importância hoje em dia.”(1998:96-97).

O espaço amplo e indefinido onde podem se dar esses encontros e agregações sociais é certamente difícil de conceber e visualizar. Muitas vezes permanece na esfera do pensamento e, hoje, com as redes sociais, se desenrola num ambiente virtual, por meio de interfaces de interação entre usuários. Foi nesse sentido, buscando abordar essas duas situações, que o grupo The Interactive Institute ${ }^{140}$ da Suécia criou a obra Think $(2007)^{141}$. A instalação se constitui de uma grande tela na qual aparecem balões de pensamento, tais como os dos

\footnotetext{
${ }^{140}$ Site do instituto: $<$ https://www.tii.se/ >

${ }^{141}$ Disponível em <https://www.youtube.com/watch?v=WVKAtpTxaVk>. Acessado em 12/05/2014. Vídeo em DVD em anexo: pasta 'Capitulo_04'>> 13. Think.mp4
} 
quadrinhos, alimentados por um sistema de interação presente tanto na sala de exposição, por meio de um teclado e um tablet (que permite enviar inclusive informação gráfica), quanto por meio de uma interface em um site na internet ${ }^{142}$, permitindo que usuários dispersos pela rede $\mathrm{e}$ aqueles que estão frequentando a exibição no momento possam dialogar em tempo real. As afinidades que podem ocorrer aí são fruto dessa interação desterritorializada cuja dimensão impalpável do pensamento não apenas ganha força, mas se torna o motivador de toda a composição da obra. Os participantes que se encontram na sala de exposição ainda podem dialogar de forma lúdica com as imagens de pensamentos que se formam na tela pois, ao aparecerem no formato de balões de quadrinhos, esses flutuam à espera de que a sombra de algum participador, que se coloca entre a projeção e a tela, complete essa imagem, tornando possível que o interator "se aproprie" de pensamentos alheios, criando um jogo a partir da identificação com o pensamento fruto da participação do outro.

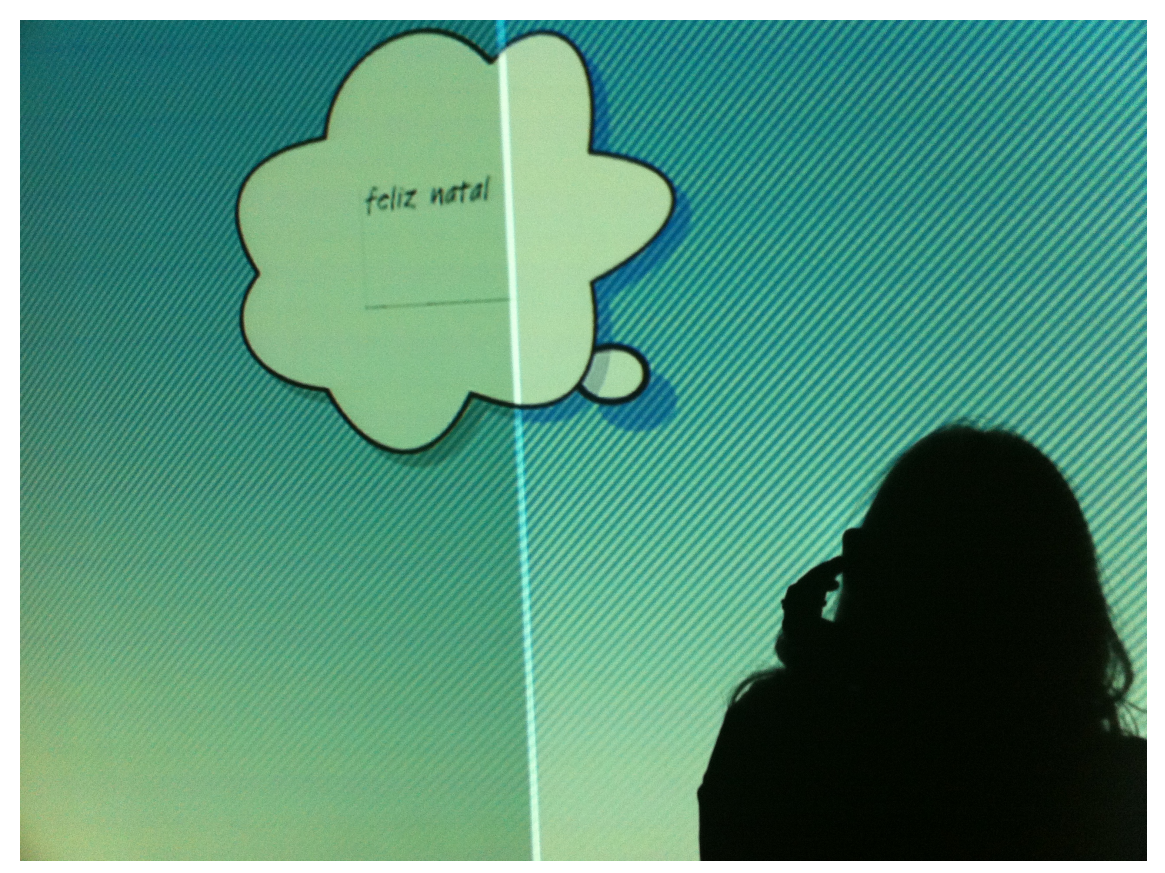

Figura 49: Think (2007), The Interactive Institute

Podemos perceber que as obras que se abrem mais que à participação, mas à possibilidade de comunhão, ou seja, de troca entre participantes, são, geralmente, obras híbridas justamente por sua constituição rizomática, criando espaços entre as relações, onde podem ser feitas as intervenções de cada um. Esse é um tipo de obra que repercute os ideais da Gesamtkunstwerk (obra de arte total, ou, mais precisamente, obra de arte comum), proposta por Richard Wagner em meados do século XIX. Para ele, a forma capaz de articular

${ }^{142}$ Vide: $<$ http://think.tii.se/index.html $>$. Acessado em 12/05/2014 
uma arte coletiva a partir da fusão entre várias manifestações artísticas seria por meio do Drama, como se fazia na Grécia Antiga. Para Goldberg, um ponto importante da Gesamtkunstwerk está relacionado à sua extraordinária espiritualidade: “Tudo leva a crer que essa obra ideal aspira ao status de templo religioso, de catedral banhada numa atmosfera de perfeita harmonia [...] encarnada naquilo que Runge chama de paisagem religiosa." (2014:41).

Ora, não seria o rito religioso justamente uma das manifestações que refletem a busca de comunhão e do estar-junto (ou do ser-com)? Tal dinâmica faz parte daquilo que Maffesoli chama de "reencantamento do mundo", em oposição ao termo "desencantamento do mundo", anteriormente empregado por Max Weber. Para Maffesoli, a procura pelo comunitário se expressa nos mais diversos tipos de manifestação em nossa sociedade, sejam de cunho esportivo, musical, consumista, midiático, religioso, entre outros: "O reencantamento pósmoderno, pelo viés da imagem, do mito, da alegoria, suscita uma estética que tem, essencialmente, uma função agregadora.” (1998:76).

Tomemos o exemplo da obra Untitled (free) ${ }^{143}$ (1992) de Rirkrit Tiravanija ${ }^{144}$, recriada no MoMA de Nova Iorque desde 2011. O artista se apropria do espaço criando uma instalação que converte a galeria de arte em cozinha, com equipamentos para preparar comida, mesas e cadeiras para estimular a interação entre o público, na qual o objetivo é servir arroz e curry gratuitamente aos visitantes da obra. A proposta é que o visitante interaja com a arte contemporânea de forma mais social, apagando as distâncias entre artista e participador e repercutindo os ideiais trazidos inicialmente pela arte dadaísta, ao mesclar as fronteiras entre o cotidiano e o artístico. Mais que um espaço, Tiravanija constrói um contexto que permite a integração e a troca entre aqueles que participam da obra: "a obra é hipotética, transitória entre situação e aquilo que ela pode produzir... ela é então pensada como um elo, nunca como um limiar, um fim, um resultado [...] o verdadeiro material da obra de Rirkrit Tiravanija é o outro.”(GOLDBERG;2014:233-234). Itzhak Goldberg ressalta ainda que a instalação deve mesmo se situar num contexto, convivendo com os movimentos sociais, senão corre o risco de se transformar em simples decoração (2014:292).

\footnotetext{
${ }^{143}$ Disponível em < https://www.youtube.com/watch?v=0xRx2s3FpSg > . Acessado em 13/05/2014. Vídeo em DVD em anexo: pasta 'Capitulo_04'> $>14$. UntitledFree.mp4

${ }^{144}$ Rirkrit Tiravanija (1961 -) é um artista tailandês, nascido em Buenos Aires e radicado em Nova Iorque. Suas obras são, na maioria, instalações onde procura estabelecer relações entre os participantes.
} 


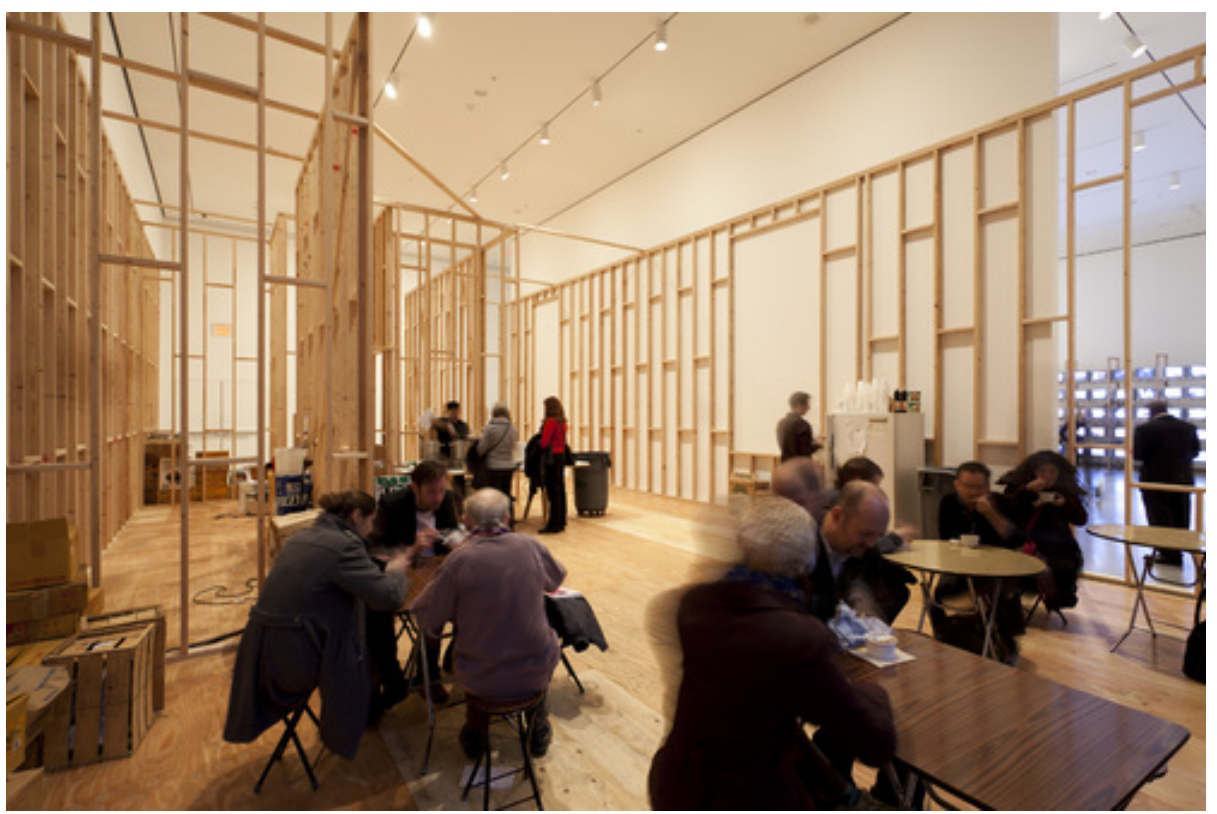

Figura 50: Untitled (free) (1992), Rirkrit Tiravanija

A obra Você tem fome de quê? ${ }^{145}$ (2005), de Rejane Spitz ${ }^{146}$, por exemplo, traz a temática da fome no Brasil e no mundo para criar uma experiência reflexiva e crítica por meio de uma instalação multimídia. O participador é convidado inicialmente a pegar uma bandeja com um prato para percorrer as várias estações em formato de totem da instalação, numa alusão ao comportamento de um consumidor de restaurante tipo self-service. Em cada um dos totens pode-se depositar a bandeja sobre uma espécie de balança, que ativa a interação com uma tela de computador. Em algumas estações pode-se assistir a vídeos com entrevistas que se pautam por perguntas tais como: O que você sabe sobre a fome? Você já passou fome na vida? O que deve ser feito para reduzir a fome no mundo? Em outras, o participador encontra dados concretos sobre a situação da fome no país e também em âmbito mundial. Em outras, ainda, pede-se que o interator forneça informações sobre seus hábitos alimentares, por exemplo.

O projeto ainda contava com o apoio de um website, na busca por aplicar os conceitos de participação e de foco no usuário, característicos da web $2.0^{147}$. Nessa plataforma, qualquer um poderia contribuir com ideias sobre como lidar com a questão da fome e da alimentação, bem como acompanhar o conteúdo que era produzido pelos participantes da exposição. A busca pela construção de um conhecimento coletivo se apropriou também de redes sociais como o twitter (@projetoFOME), mediante o qual, principalmente via dispositivos móveis

\footnotetext{
${ }^{145}$ Disponível em < https://www.youtube.com/watch?v=Gv4PgNwumpU >. Acessado em 12/05/2014. Vídeo em DVD em anexo: pasta 'Capitulo_04'> $>15$. VcTemFomeDeQue.mp4

${ }^{146}$ Rejane Spitz (1956-) é artista, professora da PUC-RJ.

${ }^{147} \mathrm{O}$ termo tornou-se conhecido para designar a segunda geração de comunidades e serviços oferecidos na web que possibilitou o surgimento de wikis e redes sociais, entre outros recursos e plataformas, abrindo mais espaço para interação e participação.
} 
como o celular, o usuário podia enviar e receber sugestões bem como criar grupos e comunidades que acompanhassem e discutissem o assunto de forma interativa e dinâmica.

Retomemos o ponto de onde partimos no início deste item: a imersão (do ponto de vista do habitar, ou ser-em) se intensifica quando vivenciada em conjunto (ser-com). Vimos que essa dinâmica, ao gerar sensações que são compartilhadas no sentido de uma "sensibilidade ecológica", como coloca Maffesoli, acaba reforçando ainda mais o aspecto social, criando uma memória coletiva a partir da experiência que é vivenciada e dividida com o outro, o que o sociólogo francês chama de 'saber incorporado' (1998:98) — e que pode muito bem se identificar ao que Merleau-Ponty designa como saber originário (e que podemos remeter também ao logos heraclitiano ou à noção de devir-imperceptível, encontrada em Deleuze e Guattari). É na esfera desses saberes que toda a dinâmica de relações com o outro intensifica o sentimento de pertença e para onde recorremos quando buscamos um sentido transcendente, mesmo sendo essa transcendência, como afirmamos tantas outras vezes e como também acredita Michel Maffesoli, uma transcendência imanente (1998:101).

Essas dinâmicas ganham dimensões desterritorializadas e praticamente ilimitadas quando pensamos nas plataformas multimídia e em rede que possibilitam a troca e a comunhão em escala global, ultrapassando barreiras de distância e culturais. Estamos aí diante do devirúltimo para onde levam todos os devires, segundo afirmam Deleuze e Guattari, ou seja um devir todo mundo como fim imanente, quando fazemos do mundo mesmo um devir, habitando confortavelmente suas zonas de indiscernibilidade. São dinâmicas que surgem a partir da vivência de experiências em movimento que, a partir da imagem contemporânea, impalpável, projetada (mas não somente dela, como vimos) criam ambientes propícios para o que podemos compreender não apenas como uma estética, mas como uma forma de ser no mundo contemporâneo: ser-em-fluxo. 


\section{5.}

\section{Fluxos entre Artemídia e Comunicação}

Retomando o pensamento de Luigi Pareyson (2001) acerca dos problemas da estética, devemos lembrar como o autor ressalta o caráter indissolúvel entre filosofia e experiência em sua constituição. Esse foi o caminho que procuramos trilhar ao longo desta pesquisa, buscando embasar conceitualmente a noção de fluxo a partir da filosofia, para, então, reconhecê-la nas manifestações artísticas mediante a experiência das obras e, finalmente, poder compreender a estética que aí se engendra.

Para Vilém Flusser, a união entre filosofia e experiência pode ser compreendida fazendo um paralelo com a dinâmica que o autor reconhece a partir de uma união pós-renascentista entre arte e técnica, ou entre estética e ciência, por meio do design (2007:183). Essa noção irá repercutir também em outros teóricos, como Stéphane Vial, para quem o design pode ser considerado uma nova cultura convergente que mistura arte, técnica, indústria, engenharia, ciência, filosofia, ciências sociais, conduzida pela esperança de inovação (2013:49-50).

Ora, se concordamos com Pareyson sobre a necessidade de se pensar uma estética do fluxo a partir da relação entre filosofia e experiência - assim como procedemos metodologicamente nesta pesquisa - , e se encontramos uma ligação entre sua proposta e a de Flusser, ou de Vial, em relação ao design, nos chama especial atenção o fato de que possamos estabelecer uma relação entre o design e a estética do fluxo. Desenvolveremos mais adiante essa ideia ao aproximar a estética do fluxo do campo da Comunicação, dialogando ainda com os conceitos estéticos apresentados por Mário Costa em 1983, quando desenvolve, junto com Fred Forest, um manifesto sobre L'Estetica della Comunicazione.

Pensar em design significa, de acordo com Moholy-Nagy, pensar em termos de relações (2005:243), outra noção importante quando abordamos o fluxo de um ponto de vista estético na contemporaneidade. Maffesoli atenta para o fato que estamos vivenciando atualmente um momento de retorno aos sentidos, ao sensível, o que nos leva a buscar o estabelecimento de laços sociais. Dá-se aí, segundo o sociólogo, um tempo de parada, em que não mais nos deixamos levar pelo movimento incessante do progresso, mas procurarmos nos harmonizar com os ritmos da existência (2012:59). Nesse sentido, nos instalamos num vir a ser permanente que o autor francês relaciona à filosofia de Heráclito, do ponto de vista de uma realidade constituída na conjugação conflitual de elementos contrários - fluxo. Nesse 
contexto, Maffesoli acredita que se sucedem não apenas períodos de anarquia, mas, ao contrário, momentos de renovação do que estava esclerosado (2012:74). Dinâmicas criativas que permitem, por meio da experiência da imersão, como vimos na observação de tantas obras de artemídia que trouxemos anteriormente, entrar em comunhão com o outro (Ibidem:87). Todo esse cenário se intensifica ainda mais, segundo Maffesoli, com ajuda do desenvolvimento tecnológico.

A partir desse pensamento, podemos conceber um fluxo contemporâneo que, diferentemente do que se dava na modernidade, não é contínuo, mas sofre rupturas, implicando um ritmo e, consequentemente, uma oscilação entre estados e possibilidades que abrem espaço para os mais variados diálogos híbridos. Mais uma vez vislumbramos a atualidade do pensamento de Heráclito que concebe um fluxo a partir da harmonia entre contrários, diferentemente do senso comum que recai sobre o conceito de um movimento contínuo. A quebra não só é característica do fluxo contemporâneo como é o que o torna possível, constitui uma contradição criativa que supõe mais a modulação que a modelagem (VERHAEGHE:2010:85). Ou seja, mais que encontrar modelos e formas, trata-se de trabalhar com módulos que permitam múltiplas e constantes reconfigurações — daí a necessidade da ruptura, que é por onde se dá a mudança.

Afinal, se pensarmos na velocidade dos tempos contemporâneos, perceberemos que, apenas mediante a quebra, podemos exercer o distanciamento heideggeriano que torna possível a observação de uma realidade na qual também estamos inseridos, ou seja, em que somos sujeito e objeto. O fluxo faz com que o devir objetivo seja acompanhado de um devir subjetivo, segundo uma característica própria, participativa e ativa que pressupõe uma realidade imanente e partilhada: “O fluxo é o processo que anima todos os reencontros nos quais são confundidos valores subjetivos e valores objetivos.” (VERHAGHE;2010:155). Portanto, podemos vislumbrar uma estética do fluxo como método de observação a partir da experiência, assim como Verhaghe acredita em relação ao próprio contemporâneo, ao se ocupar de um pensamento da gênese daquilo que acontece, buscando compreender as articulações pelas quais se movem os fluxos do mundo (Ibidem:244).

Numa contemporaneidade tomada pela técnica, especificamente pela técnica comunicacional - como pudemos perceber nas apropriações da artemídia — o autor afirma que a noção de interatividade estaria na base do fluxo. Para Jean-Louis Boissier, é a interatividade que garante uma arte da relação (apud VENTURELLI;2011:76). Ao priorizar o aspecto social, o fluxo dá destaque, como viemos falando ao longo desta pesquisa, ao entre; ao diálogo. Verhaghe afirma que o fluxo, em si, não existiria, mas seria uma espécie de 
sintagma conceitual que fundaria uma estética a partir de coisas que não se mostram (2010:551). E, diante disso, o autor acredita haver um paradoxo ao se falar em "estética do fluxo", pois sua concepção de 'estética' implica num "tipo de ideia ou uma família de critérios visuais aos quais nos reportar." (Ibidem:551).

Concordamos com o autor no sentido de não vislumbrarmos uma materialidade do fluxo, daí a necessidade de pensá-lo por meio da experiência e, consequentemente, da estética. No entanto, discordamos da continuidade de seu pensamento. Diferentemente de Verhaghe, acreditamos que a estética não forma um determinado critério visual tal como, por vezes, encontramos em um movimento ou escola artística - apesar de podermos reconhecê-la, muitas vezes, a partir de uma descrição que se inicia pela abordagem visual. A estética (no caso a estética do fluxo) se compõe sobre vivências que remetem à percepção e ao despertar de sensações (aisthesis) envolvendo todo o corpo, não apenas a visão, e apesar de tangenciar o aspecto visual, não se limita a ele.

É justamente pela força da vivência em sua constituição que a estética (especialmente a estética do fluxo) estimula o compartilhamento e promove o estabelecimento de relações característica tão importante para se pensar a estética do fluxo como método de compreensão da contemporaneidade, conforme aponta o próprio Verhaghe (2010:244). Reduzir a estética meramente ao aspecto visual acaba por desvincular toda a dimensão não visível das dinâmicas da experiência do fluxo - aspecto importante para uma vivência global das obras de artemídia, tal como pudemos observar nos percursos realizados ao longo da pesquisa. O fluxo que se faz perceber de maneira estética é contraditório, posto que visível e invisível concomitantemente; é contínuo e descontínuo, cheio de rupturas. Portanto, não enxergamos aí o paradoxo apontado por Verhaghe.

A imaterialidade do fluxo ganha ainda mais destaque ao nos voltarmos ao aspecto tecnológico dessas experiências. Para Mario Costa, essa seria a característica principal do fluxo ou da estética daí derivada: o aporte tecnológico. Tanto que, quando o autor fala sobre fluxo tecnológico, podemos perceber que se refere, na verdade, a uma estética da comunicação:

Sobre o fluxo tecnológico se embasa na verdade a estética da comunicação ${ }^{148}$, é o fluxo tecnológico que funciona como um bloco comunicante $^{149}$, e é do fluxo tecnológico que nascem muitas modalidades do

\footnotetext{
${ }^{148} \mathrm{O}$ autor aqui traz uma nota: "O primeiro princípio da estética da comunicação sustentava que 'A estética da comunicação é uma estética de eventos. O evento é aquilo que se subtrai à forma e se apresenta como fluxo espaço-temporal', New and Notes, Artmedia, Salerno, janeiro 1986, p. 5" (COSTA; 2010:75)

${ }^{149}$ Outra nota do autor: "A contradição que parece existir entre fluxo e bloco comunicante é apenas aparente, pois o fluxo, enquanto extensor e onipenetrante funciona desde sempre como um sistema fechado e portanto como um bloco.” (Ibidem: Idem)
} 
sublime do qual falamos. É portanto ao fluxo tecnológico que a pesquisa estética deve se voltar, é sobre o fluxo tecnológico em geral que essa deve exercitar-se e não sobre o significado e sobre o simbólico que o atravessam sem constituir-lhe a essência. (COSTA; 2010: 75)

Ao escrever sobre a estética do fluxo e sua relação com a arte contemporânea (2010), Costa se volta constantemente aos conceitos elaborados na década de 1980 quando escreveu o manifesto sobre a estética da comunicação ${ }^{150}$ — uma se confunde com a outra justamente pelo fato das tecnologias comunicacionais, e os eventos derivados do uso dessa tecnologias, constituírem a base de todo o pensamento voltado a ambas manifestações estéticas. Para o filósofo, como a substância da comunicação se faz cada vez mais impalpável e imaterial "a desmaterialização da obra deve ser prosseguida, o estético deve, cada vez mais, consistir numa sutil, difusa e multipresente espiritualidade intelectual e, sempre menos numa qualidade sensível das coisas." (1999:16). Costa entende o fluxo, especialmente o fluxo tecnológico que não podemos ver ou tocar, como a base de uma estética do fluxo ou de uma estética da comunicação e isso implicaria num deslocamento do sensível ao tecnológico.

Para Costa, Bergson seria o primeiro teórico do fluxo tecnológico da modernidade, ao falar sobre os processos cinematográficos, trazendo uma essência da técnica para o âmbito do pensamento (2010:76). E como Deleuze repercute a teoria bergsoniana, principalmente ao elaborar seus conceitos de imagem-movimento e imagem-tempo, Mario Costa acaba por abordar o pensamento dos dois filósofos franceses ao falar sobre fluxo tecnológico ou fluxo comunicacional, na busca por uma compreensão estética. O autor italiano destaca a importância do conceito de imagem-cristal proposto por Deleuze, justamente pela sua flexibilidade, no entanto, ele questiona fortemente o fato de Deleuze falar em fluxo sem considerar o aspecto técnico, ou seja, sem se voltar à tecnologia mesma que torna possível a projeção e fruição das imagens cinematográficas, privilegiando apenas o aspecto humano. Para Costa, o fluxo só é entendido como tal a partir de uma noção de fluxo estético tecnológico.

Nos pareceu interessante a crítica de Mario Costa à Deleuze destacar o fato de o filósofo não abordar o cinema abstrato, mas apenas o narrativo-figurativo. Justamente em vários

\footnotetext{
${ }^{150}$ Costa assume a Estética da Comunicação como uma estética de eventos, como vimos em nota anterior. Esse evento se caracterizaria por alguns princípios: 1) é aquilo que se subtrai à forma e se apresenta como fluxo espaço-temporal ou processo interativo e vivente.; 2) se realiza por meio de um dispositivo tecnológico de contato à distância capaz de relacionar espaços diversos ao mesmo tempo; 3) consiste, antes de tudo, na ativação de um circuito, ressaltando a importância da rede de trocas; 4) se volta ao tempo real; 5) é uma mobilização de energia (vital - mental, muscular, afetiva, orgânica, etc. - e artificial - eletricidade, eletrônica, da máquina, etc.); 6) resulta sempre em duas noções temporais interagentes: o presente e a simultaneidade; 7) emprega o espaço-tempo como suporte para a criação de novos equilíbrios sensoriais; 8) desfecha e ativa uma nova fenomenologia da presença; 9) gera um sentimento estético que se distancia do belo e se aproxima ao sublime; 10) oferece a possibilidade de produção e consumo de uma sublimidade. (1999: 32-33)
} 
exemplos do cinema abstrato encontramos significativas manifestações do fluxo, principalmente na sua relação oscilante do ritmo entre imagem e som, como abordado no segundo capítulo. Para Mário Costa é também na característica óptico-sonora dessas imagens que reside sua importância pois, para o autor, dessa forma se torna perceptível a participação da tecnologia no processo de construção dessas mesmas imagens.

Costa concebe um fluxo puramente tecnológico: "O fluxo não é, portanto, uma característica da consciência mas é um modo de funcionamento de certa tecnologia, de tudo externo à consciência mesma" (2010:109). Nesse ponto discordamos do autor. Acreditamos que o fluxo, na contemporaneidade, se manifesta como estética numa relação entre esses dois aspectos, o humano e o tecnológico, que devem ser tomados não como contrários, mas como complementares. Ou, como propõe um pensamento do fluxo, num embate que permaneça na harmonia/desarmonia entre contrários. Vimos que, ao habitar espaços imaginários, a percepção oscila entre as imagens visíveis, propostas pelo aparelho tecnológico, e aquelas que as complementam, vindas da consciência, não visíveis. A experiência resultante daí é híbrida: meio real, meio virtual; meio visível, meio invisível; ou, se quisermos abordar o aspecto em questão, meio humana, meio tecnológica. A concepção de Costa enxerga no fluxo apenas a sua imaterialidade, ou seu lado não visível.

Na obra Generation $244^{151}$ (2011), de Scott Draves ${ }^{152}$, parte da $6^{\text {a }}$ edição da Bienal Internacional de Arte e Tecnologia, Emoção Art.Ficial (2012), do Istituto Itaú Cultural, em São Paulo, pudemos vislumbrar um fluxo tecnológico, como abordado por Mario Costa. A videoinstalação se constitui pela projeção de uma animação abstrata que ocupa as paredes e o chão do ambiente onde é exibida. Cada imagem construída não se repete nunca, pois é o resultado de uma equação organizada segundo grande quantidade de parâmetros e variáveis calculados com intuito de formarem representações gráficas do conceito de evolução darwiniana, constituindo uma espécie de mente cibernética ligada a centenas de milhares de computadores espalhados pelo mundo e gerando uma forma de vida artificial. A primeira versão da obra é de 1999 e Draves a vem aprimorando desde então, chegando ao resultado de um vídeo não-linear que se desenrola numa sequência sempre inédita.

\footnotetext{
${ }^{151}$ Disponível em: <https://www.youtube.com/watch?v=tseu2nCl0r4 > Acessado em 28/04/2014. Vídeo em DVD em anexo: pasta'Capitulo_05'>> 01.Generation244.mp4

${ }_{152}$ Draves se apresenta como "software artist". Vide site do artista: $<$ http://scottdraves.com/ >
} 


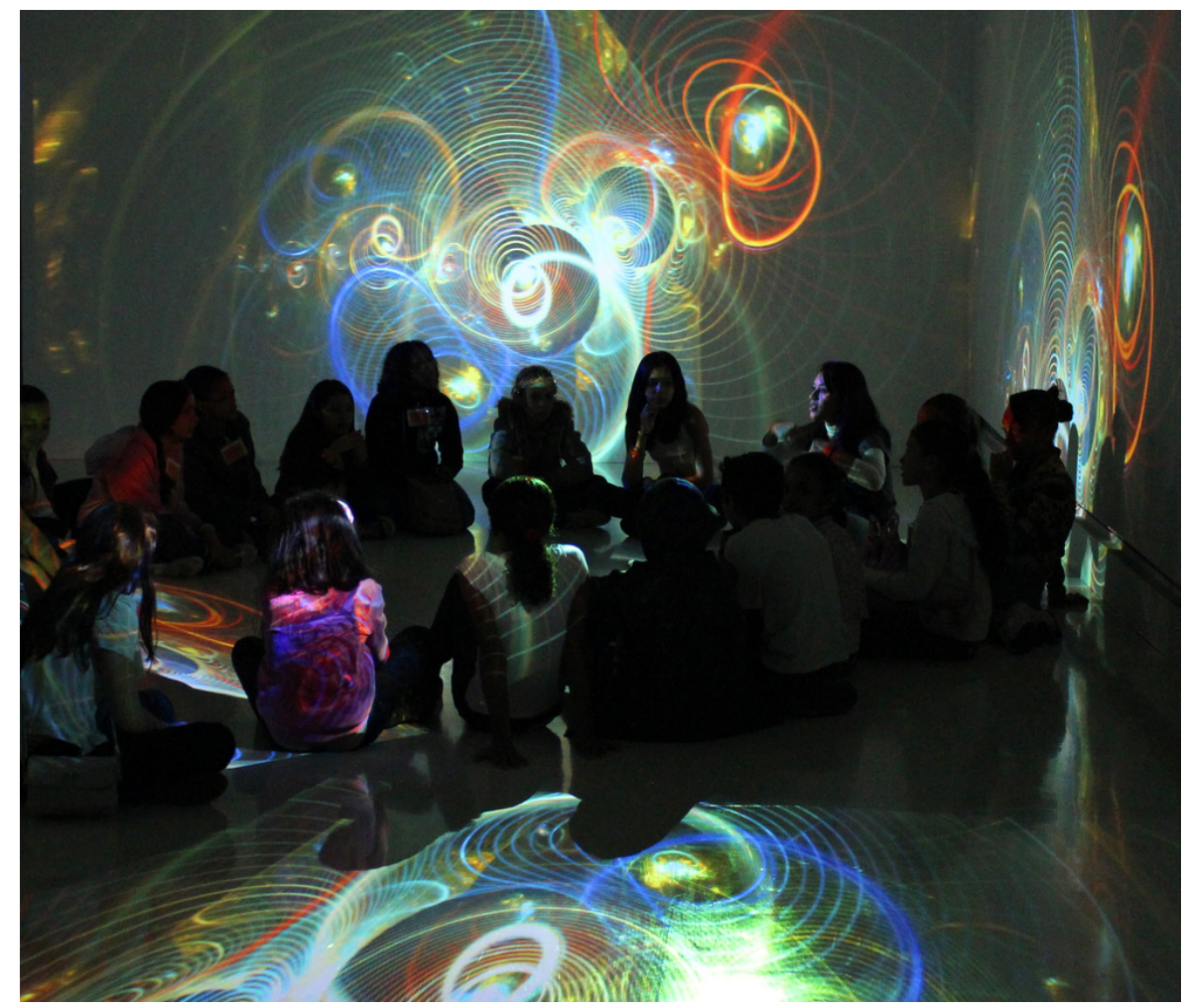

Figura 51: Generation 244 (2011), Scott Draves

Ao pensarmos nessa imagem animada e projetada, em como ela é gerada a partir da imaterialidade da luz e de códigos binários, encontraremos aí apenas dados informacionais, ou seja, uma clara manifestação visual do que Mario Costa chama de fluxo tecnológico. No entanto, ao participarmos da experiência da videoinstalação no espaço, a relação da imagem com o nosso corpo ganha outra dimensão. O próprio Scott Draves, ao figurar no vídeo que divulga sua obra, se desloca pelo ambiente, observa como as imagens interagem com seu corpo, como se projetam sobre ele e torna-se parte da própria imagem, inserindo-se no fluxo, que deixa de ser puramente tecnológico. O apelo da imagem impalpável provoca a relação e invoca o aspecto humano. Além disso, o estímulo à participação é parte constituinte do próprio movimento e das configurações visuais da animação apresentada na sala do museu, mesmo de quem não está presencialmente ali. Qualquer usuário pode se cadastrar no site que dá suporte à obra (www.electricsheep.org) ou baixar um aplicativo para dispositivos móveis que permita que seu computador interaja com a obra, interferindo nas formas que serão mostradas pela animação.

Quando Mário Costa afirma que o tempo da consciência começa a vacilar em detrimento de um tempo tecnológico, só podemos concordar parcialmente com o autor. Também acreditamos que cada tecnologia dá lugar a uma espécie de tempo e de funcionamento próprios, no entanto, ao se relacionar com um humano, principalmente por meio da imagem, 
esse fluxo tecnológico institui um diálogo com as temporalidades subjetivas daquele que interage com ele. A percepção do próprio fluxo implica uma consulta ao imaginário que transforma o caráter dessa percepção, tornando-a híbrida com vários estados de consciência, assim como experimentamos quando estamos em devaneio. Dessa forma, acreditamos que a tecnologia em si não é o suficiente para criar uma temporalidade da imagem na relação com o participador mas, sim, a vivência dessa tecnologia, ou do fluxo tecnológico pelo mesmo participador.

Uma obra que nos chama particular atenção nesse sentido é Zee ${ }^{153}$ (2008), de Kurt Hentschläger ${ }^{154}$, exposta no Festival Némo, Espace Centquatre, em Paris (2013). Ela se constitui como uma instalação imersiva que cria um ambiente artificial a partir de névoa espessa, luzes estroboscópicas cintilantes e som. Ao aguardar para adentrar a obra, recebemos um aviso por escrito acerca dos perigos de participar da instalação, tendo em vista que ela altera a percepção do espaço, diminuindo a profundidade de campo e, consequentemente, o senso de orientação no ambiente. A principal instrução antes de adentrar a câmara clara e neblinada é de que nos apoiemos em uma corda que guiará o percurso que devemos fazer ao longo da experiência. Nos primeiros momentos ainda vislumbramos um vulto do participador à nossa frente, em seguida, esse vulto se perde e o denso nevoeiro que dissipa qualquer noção de limite, forma ou fronteira, toma conta de toda nossa percepção de maneira sinestésica. Nos sentimos suspensos junto às partículas de vapor, mas continuamos com os pés no chão fluxo. A corda é o único guia, linha que segue o percurso, "é o fio de Ariadne no labirinto branco" $" 155$.

A luz estroboscópica e cintilante que ilumina a neblina possibilita a percepção visual de estruturas caleidoscópicas em movimento, totalmente impalpáveis que, em conjunto com o som, geram uma paisagem insólita que envolve o visitante. Experimentamos a sensação de devir fluxo não material de bruma e luz, passando, nós também, a fazer parte dessa paisagem - ela própria uma tela em branco (tabula rasa, como propõe o artista) para se completar mediante o diálogo com as imagens mentais do participador, constituindo um híbrido de estados de consciência diversos. Uma obra que não parte de uma imagem específica, mas se utiliza de fluxos tecnológicos diversos para provocar a criação de novas imagens pelo participador a cada vivência. Vemos aí como a temporalidade resultante desse encontro entre

\footnotetext{
${ }^{153}$ Disponível em: $<$ https://www.youtube.com/watch?v=FDco6ImZH7A > Acessado em 28/04/2014. Vídeos em DVD em anexo: pasta 'Capitulo_05' >>02.Zee.mp4

${ }^{154}$ Kurt Hentschläger é austríaco, radicado em Chicago. Sua obra se volta à criação de performances audiovisuais e instalações de caráter imersivo. Site do artista: < http://www.kurthentschlager.com/ >

${ }^{155}$ Comentário realizado pelo orientador desta pesquisa, Prof.Dr. Gustavo de Castro, ao ler sobre a obra.
} 
o estímulo tecnológico e a experiência humana é subjetivo e variável, não apenas atrelado ao tipo de aparelho técnico, como acredita Mario Costa.

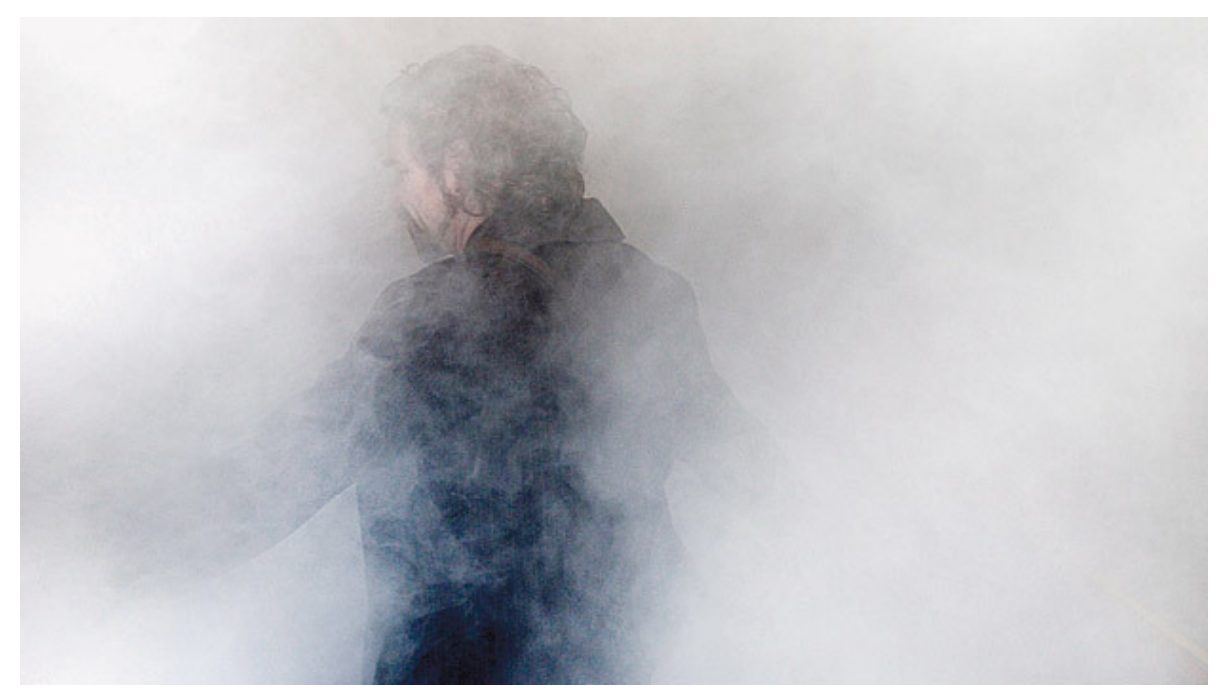

Figura 52: Zee (2008), Kurt Hentschläger

O autor ainda afirma que, para liquidar o tempo psicológico do fluxo e nos atermos apenas ao tempo tecnológico, faz-se necessário que o fluxo se desenrole em tempo real, ou seja, não naquele presente em que necessariamente também o passado reatualizado se desenrola, mas num presente que é a contemporaneidade do fluxo temporal que estaríamos biologicamente desenvolvendo (2010:122). Ora, lembremos do que Merleau-Ponty afirma em relação à percepção pois, para o autor, uma mera atualização das recordações não é o suficiente para se introduzir na percepção atual uma atividade mental. Precisamos de um diálogo entre estados de consciência diversos que permita vivenciar novamente as experiências recordadas em uma situação espaço-temporal diversa. Não podemos apenas descartar o papel do passado reatualizado nas dinâmicas perceptivas, nem mesmo confundi-lo com o conceito de "recordação". Recorremos às recordações mais para vivenciar outras experiências que a cada "tempo real" se renovam e se mostram inéditas, mesmo no diálogo com experiências anteriores, pois estamos diante de condições espaciais e temporais também inéditas. Essa dinâmica, por si só, não constitui um requisito suficiente para se considerar o fluxo como presenteísta e meramente tecnológico.

Mario Costa cita as obras All Over ${ }^{156}$ (2010) de Samuel Bianchini ${ }^{157}$ e Fractal Flowers ${ }^{158}$ (2008), de Miguel Chevalier ${ }^{159}$, como exemplos desse fluxo em tempo real que assume seu

\footnotetext{
${ }^{156}$ Disponível em: < https://www.youtube.com/watch?v=HxH7dontSAU > Acessado em 28/04/2014. Vídeo em DVD em anexo: pasta 'Capitulo_05 >> 03.AllOver.mp4 .

${ }^{157}$ Site do artista: $<$ http://dispotheque.org/ >
} 
aspecto tecnológico (2010:133), aproximando-se do que ele chama de sublime tecnológico ${ }^{160}$. Na primeira obra, observamos uma série de imagens compostas de caracteres tipográficos que se alteram, seguindo os fluxos informacionais das bolsas de valores em todo mundo, provocando pequenas alterações também nas imagens resultantes da relação entre esses caracteres. Já no caso da segunda obra, estamos diante de um jardim virtual de flores fractais gigantes, de diferentes cores e formas, geradas ilimitadamente graças a um software. Essa obra se apoia sobre um princípio generativo, criando sementes virtuais autônomas das quais nascem outras flores que se desenvolvem e morrem aleatoriamente. Essa dinâmica está diretamente ligada à passagem dos visitantes diante da tela, ressaltando sua característica interativa. E, justamente acerca desse aspecto, parte nossa indagação: como podemos conceber um fluxo meramente tecnológico se ele é interativo, ou seja, se depende da ação do corpo do participador para se concretizar?

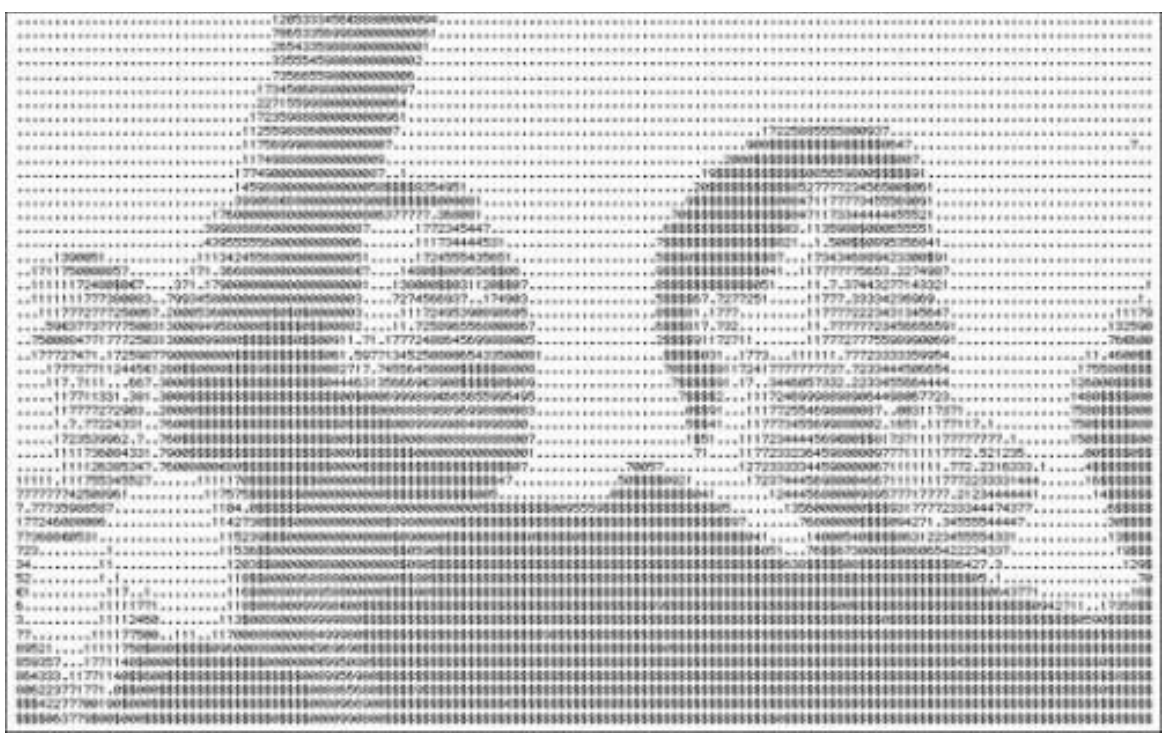

Figura 53: All Over (2010), Samuel Bianchini

\footnotetext{
${ }^{158}$ Disponível em: < https://www.youtube.com/watch?v=9tIY4773x90> Acessado em 28/04/2014. Vídeo em DVD em anexo: pasta'Capitulo_05' >> 04.FractalFlowers.mp4

${ }^{159}$ Miguel Chevalier (1959 - ). Artista mexicano radicado em Paris. Trabalha com novos meios informáticos. Site do artista: $<\mathrm{http}: / /$ www.miguel-chevalier.com/fr/index.html >

${ }^{160}$ Para Costa, a ideia de sublime tecnológico implica um decréscimo progressivo da subjetividade (FABRIS in COSTA1995:9). Ao ligar o sublime tecnológico à arte, a função do artista não seria mais a de exprimir-se ou de dar forma ao mundo mas de criar dispositivos comunicacionais (COSTA;1995:33) que geram imagens, palavras, movimentos e sons tecnológicos, subtraídos ao corpo (Ibidem:45) e, consequentemente, interrompem toda circulação simbólica, "não geram processos imaginários e subsistem independentemente deles". (Ibidem:47). Concordamos com o autor no que diz respeito ao papel do artista voltar-se mais à criação de dispositivos para gerar experiências e não tanto de obras que representem uma expressão pessoal apenas, conforme abordaremos mais adiante. No entanto, essas mesmas obras buscam criar diálogos que partem do próprio artista em direção à obra e ao participador. Desse processo não há como subtrair a dimensão subjetiva tanto do artista quanto do participador - , muito menos subtrair os processos imaginários que são necessários para a imersão e participação global na obra, como pudemos experimentar ao vivenciar o percurso de diversas obras no decorrer da pesquisa.
} 


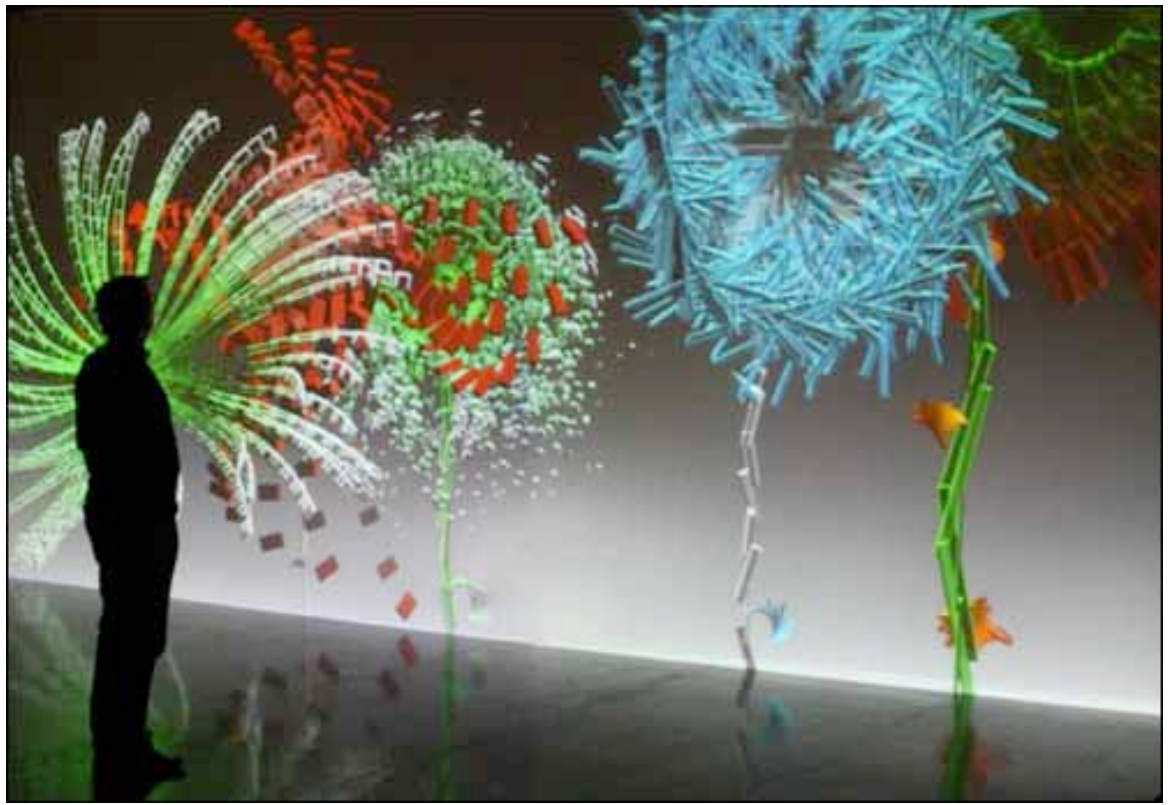

Figura 54: Fractal Flowers (2008), Miguel Chevalier

Não há como pedir que o visitante se esqueça de outras experiências vividas ou que se dispa de seus diversos estados de consciência no momento em que entra em contato com a obra. Mesmo no caso de All Over (2010), toda ação que se desenrola depende de ações de humanos que estão por trás dos computadores que controlam as bolsas de valores e, mais ainda, dependem de questões outras que se inserem em contextos tão diversos do mundo mercantil que não há como medir ou avaliar, mas que envolvem também aspectos humanos e não apenas tecnológicos. Claro que o papel do artista, ao deixar em aberto a significação da obra, intensifica, sim, a etapa de projetar o dispositivo. Concordamos com o autor italiano nessa questão, pois talvez esse seja o grande papel do produtor de arte na contemporaneidade. No entanto, essa obra permanece em aberto justamente para se completar com a participação do visitante, ou seja, num diálogo que se estabelecerá com seu imaginário, posto que não há como extirpá-lo no momento de fruição de uma instalação multimídia. Também não há como separá-lo do corpo, portanto, não conseguimos visualizar uma situação em que as imagens, sons e movimentos criados tecnologicamente se desvinculem completamente de uma relação com a subjetividade de quem interage com a obra e, dessa forma, não podemos concordar totalmente com a definição de sublime tecnológico trazida pelo autor.

No Brasil podemos citar o exemplo de Iflux $^{161}$ (2012) de Silvia Laurentiz ${ }^{162}$ e Martha Gabriel $^{163}$, exposta na $6^{\mathrm{a}}$ Bienal Internacional de Arte e Tecnologia, Emoção Art.Ficial

\footnotetext{
${ }^{161}$ Disponível em: < https://www.youtube.com/watch?v=FXsK4D6M274 > Acessado em 28/04/2014. Vídeo em DVD em anexo: pasta 'Capitulo 05 >> 05.Iflux.mp4

${ }^{162}$ Silvia Laurentiz é artista, designer multimídia, professora e pesquisadora da USP.

${ }^{163}$ Martha Gabriel é artista, escritora, consultora e palestrante nas áreas marketing digital. Site: <martha.com.br $>$
} 
(2012), do Itaú Cultural. A obra se constitui como arte sistêmica, interativa e dinâmica que trabalha com fluxos de informação de diversas naturezas. Na instalação vemos uma tela onde encontramos uma espécie de "chuva digital" que anima os movimentos de um corpo virtual, de acordo com as mudanças sofridas em cada um dos seguintes fluxos: redes internas, rede elétrica, rede hidráulica e entradas e saídas de pessoas do prédio onde a instalação se encontra, no Instituto Itaú Cultural, em São Paulo. Aí também temos uma obra que, à primeira vista, se regularia apenas por fluxos tecnológicos. No entanto, se pensarmos nas ações que estão por trás de cada uma das mudanças computadas, podemos encontrar a figura humana que utiliza os recursos do prédio de acordo com suas necessidades.

Costa acredita que o ponto de chegada de todos os fluxos seria o de confluência a um único e potente fluxo tecnológico em que não importa o significado, mas apenas o meio (medium) técnico em si (2010:126). E, assim, do espiritual a estética passaria a se ocupar do sensorial (Ibidem:136). Neste último aspecto concordamos com o autor. No entanto, enquanto ele desenvolve essa ideia na direção de uma instrumentalidade tecnológica, nós seguimos no caminho de uma transcendência imanente que se daria na orientação de um diálogo consigo mesmo, com as imagens mentais do devaneio e das experiências que dialogam com os vários estados de consciência, sem descartar as possibilidades de hibridização com a tecnologia e os meios de comunicação, já que acreditamos, como afirmamos outras vezes, que não faz mais sentido pensar na distinção homem-máquina.

\subsection{Trans-imanência: experiência e devir na ontofania das imagens técnicas}

Falamos anteriormente sobre como a experiência proporcionada pelas obras de artemídia pode ser uma forma de adentrar um estado de trans-imanência, permitindo o trânsito entre o interior e o exterior, entre sujeito e objeto, quando então nos abrimos para a relação com o outro numa busca por um sentimento de pertença. Para Maffesoli, quando nos situamos em um momento em que o quotidiano torna-se comunitário (vide redes sociais como facebook, por exemplo), as grandes instituições tornam-se difusas, tais como o Estado, a Tecnoestrutura e até mesmo a noção de Deus (divino difuso) e, nesse contexto, podemos falar de uma transcendência imanente, isto é: "de um espírito do tempo que ultrapassa o indivíduo (portanto, algo de transcendente), mas que recai sobre o grupo, constituindo o cimento deste mesmo grupo (o que é imanente).”(2012:27).

Nessa ambiência difusa na qual a partilha do quotidiano é o elemento central (Ibidem:Idem), temos de lembrar que, a cada compartilhamento, esse coletivo se transforma, 
instaurando-se num constante devir. Dá-se, portanto, uma socialidade do vir-a-ser (MAFFESOLI;2012:103) que caracteriza o fluxo contemporâneo, ou seja, quando falamos em fluxo não há como deixar de lado o aspecto social, ou da relação. Nem há como ignorar o aspecto da técnica, sobre o qual já tecemos algumas considerações. Assim como Mario Costa, Stéphane Vial também acredita que cada técnica, em sua determinada época, provoca mudanças que alteram nosso ser-no-mundo. A essa dinâmica, ele relaciona o conceito de ontofania. No entanto, diferentemente de Costa, Vial vislumbra uma possibilidade de transcendência a partir da técnica, próxima àquilo que chamamos trans-imanência: "A técnica não é mais transcendente ao homem que a ciência ou a arte [...] A transcendência da técnica não é nada a mais do que a condição de sua imanência.” (VIAL;2013:60-61).

Além de alterar a ontofania, as mudanças na técnica alteram também a percepção, justamente pelo fato da percepção não ser apenas uma função do corpo ou da consciência mas, também, uma função social. Trata-se, portanto, de uma revolução fenomenológica, algo que ocorre toda vez que o ato de perceber é modificado por uma inovação artística, científica ou tecnológica, abalando nossos hábitos perceptivos da matéria e a própria ideia que fazemos da realidade (Ibidem:96-97). Por ser uma estrutura da percepção, a técnica condiciona a forma como o mundo ou o ser se manifestam e altera toda a ontofania do mundo, a ponto de Vial afirmar que a "fenomenotécnica" (phénoménotechnique) estende a fenomenologia (2013:102). O simples fato de um fenômeno do mundo se manifestar se dá de maneira diferente se esse se situa no período pré-mecânico ou digital pois, em cada caso, a ontofania se constitui em oferecer ao sujeito, segundo as qualidades perceptivas condicionadas tecnicamente, uma experiência de mundo única e possível apenas naquela dada época e configuração técnica.

A experiência é nela mesma uma construção fenomenotécnica: enquanto
interação perceptiva entre o sujeito e o fenômeno, ela é sempre tecnicamente
produzida - e não somente tecnicamente mediada ou influenciada. Por
fenomenotécnica é necessário então compreender o fato que um princípio
técnico pode condicionar a fenomenalidade de um fenômeno. A
fenomenotécnica é a construção técnica da ontofania. É por isso que a
técnica se apresenta como uma matriz ontofânica, a saber: como um molde
fenomenológico, produzido pela cultura e pela história, da qual escapa nossa
experiência-do-mundo possível. (VIAL;2013:116)

O real ou o ser, portanto, são sempre particulares e acidentais, sensíveis às condições da técnica de cada época e, como afirma Vial, não podemos compreender as estruturas ontológicas como invariantes mas, pelo contrário, como fenomenológicas e cambiantes (2013:119-120). De forma que cada vez que surge na história humana um novo aparelho, é 
toda uma forma de partilha do sensível que deve se reajustar (Ibidem :132), tal como vivenciamos na contemporaneidade quando, devido aos desenvolvimentos técnicos que permitem maior mobilidade em tempo real, desvinculada dos limites do espaço físicogeográfico (como no caso dos smartphones), observamos a dinâmica do compartilhamento se desenrolar ubiquamente.

Para Vial, ao nascermos já em meio à tecnologia digital, nos tornamos nativos digitais que convivem naturalmente com a relação entre real e virtual, pois o virtual tem a vocação de se hibridar ao real, constituindo um complexo real-virtual, ou uma realidade composta (2013:174), ou o novo real, expandido. Para o autor, a virtualidade faz parte integrante da ontofania do mundo contemporâneo, condicionada pelos aparelhos digitais (Ibidem:176), de maneira que pensar num "ciberespaço" seria um conceito já datado e fenomenologicamente extinto, ancorado na ilusão metafísica que o virtual carrega (Ibidem:182-183).

Partilhamos da mesma ideia, pois acreditamos que conceber um "ciberespaço" destacado do real não faz mais sentido, como afirmamos tantas outras vezes. Já houve uma época em que não apenas havia um motivo, como era necessário fazer tal separação para uma melhor compreensão do estado das coisas, pois se estava diante de uma nova técnica e de mudanças fenomenológicas que alteraram nossa experiência de estar no mundo e que impuseram uma ontofania emergente. Decorridas algumas décadas já aprendemos a conviver com as interfaces digitais e com os mundos criados por meio delas: "A virtualidade na qual vivemos não é mais que um aspecto entre outros da fenomenotécnica geral induzida pelos aparelhos digitais" (VIAL;2013:184).

A ontofania digital implicaria, segundo o autor, numa fenomenologia do instável, em que temos o sentimento de viver em meio à matéria instável (imagens impalpáveis) e ao imprevisível (múltiplas configurações possíveis) (2013:216-217) — estética do fluxo. Essa estrutura só pode ser apreendida por meio de uma organização em rede que permita momentâneas atualizações dessa instabilidade mediante a ligação com o outro. Vial afirma que a rede pode ser considerada a matriz ontofânica das novas formas de estabelecimento de elos sociais, ou "uma nova estrutura tecno-transcendental da sociabilidade" (Ibidem:223).

Vemos, portanto, como a técnica e, consequentemente, todo o aparato tecnológico que proporciona as manifestações artísticas da contemporaneidade, principalmente no caso da artemídia que analisamos, dinamizam as relações num mundo digital, virtualizado e, dessa forma, tornam possível uma trans-imanência característica da expressão de uma estética do fluxo. Não uma transcendência divina, mas social, grupal e, portanto, imanente. Roy Ascott afirma que a virtualidade e a rede de computadores acabam, de certa forma, respondendo aos 
nossos desejos psicológicos de transcendência, de estar fora do corpo e extrapolar os limites de tempo e espaço (2003:223). Compreendemos agora como esses desejos são um reflexo da nossa necessidade de uma "transcendência da sociabilidade".

A virtualidade, além de estender o tempo e o espaço para além da imediatez sensorial, só se completa com a construção do objeto independente das percepções e dos atos do sujeito individual, "um objeto cuja imagem sensível, cujo manejo, cujo feito causal ou cujo conceito possa ser compartilhado por outros sujeitos."(LÈVY;1996:132). Vemos que a não distinção entre real e virtual também faz parte de um processo de humanização da tecnologia, como defende Frank Popper. Para o autor, esse sistema só se torna possível mediante a interatividade, a imersão sensorial a partir de uma imaginação artística (2007:355), tal como encontramos nas obras analisadas anteriormente. A humanização da tecnologia, portanto, também é reflexo dessa necessidade de uma transcendência que não passa pela esfera divina, mas humana e, consequentemente, mostra como também não existe mais motivo em se divinizar a tecnologia ou o ambiente virtual, o que reforça, mais uma vez, nossa proposta de indiscernibilidade entre real e virtual.

Edmond Couchot complementa essa argumentação ao afirmar que a tecnologia em si não faz desaparecer o sagrado, mas o desloca. Segundo o autor, ela o esvazia parcialmente de seu conteúdo religioso do divino, banalizando-o sob o verniz da razão. Ela o retoma em sua função de: “fundar o princípio de uma transcendência na qual os sentidos se originam. L'axis mundi que separava o profano do sagrado passa agora pela interface." (1998:248). Ao falarmos em transcendência imanente, ou de trans-imanência, devemos contemplar a importância da experiência sensorial pois acreditamos que somente por meio dela é possível transcender sem necessariamente buscar, num primeiro momento, algo externo a nós mesmos. A trans-imanência, portanto, segue um movimento inicialmente para dentro (de nós mesmos) e posteriormente para fora novamente; para o ambiente de onde partem os estímulos externos iniciais que a tornam possível e onde também se encontram os demais que compartilharão da experiência — ou onde podemos encontrar o imenso que circunda e recebe cada sujeito, conforme veremos a seguir.

A manifestação da transcendência imanente se dá de forma sinestésica, aproximando-se do que Merleau-Ponty chamou de "camada originária" do sentir, que seria anterior à divisão dos sentidos (2011:305). Aí, segundo o filósofo, dá-se uma coexistência do sujeito com o fenômeno, um momento "em que, sob todos os aspectos, ele estaria em seu máximo de articulação e os dados dos diferentes sentidos estão orientados em direção a um polo único" (Ibidem:426-427) — que podemos relacionar ao uno heraclitiano. Nessa dimensão, a 
imanência deve ser entendida não apenas como instância interior, mas como relação, como propõe Sloterdjik (2003:539), quando o ser-com supera o ser-em, ou seja a busca do "eu" segue em direção ao outro na imensidade do exterior. Nesse sentido, o ser-em significaria, segundo o filósofo alemão, viver na imensidão (Ibidem:561).

Talvez possamos encontrar aí um substituto para a dimensão metafísica da transcendência. Ou seja, na trans-imanência, partiríamos de uma experiência subjetiva rumo a uma imensidão que pode ser compreendida pelo coletivo. Para Bachelard, a imensidão é uma categoria filosófica do devaneio (2008:189) que nos remete, portanto, a uma consciência imaginante, assim como observamos no terceiro capítulo acerca das possiblidades de se habitar o imaginário mediante o devaneio e o compartilhamento da experiência, gerando o sentimento de estar-junto. Para o filósofo, a imensidão está em nós mesmos, "ligada a uma espécie de expansão de ser que a vida refreia, que a prudência detém, mas que retorna à solidão." (Ibidem:190). Dessa forma podemos entender como, apesar de estarmos sempre em contato com o outro e procurarmos compartilhar nossas experiências, essas são efêmeras e nos remontam novamente ao estado de solidão, levando-nos a recomeçar o ciclo que impulsiona a busca por novas experiências.

Essa relação entre interior e exterior parece um tanto contraditória. No entanto, é justamente na imensidão coletiva que esse embate de contrários encontra sua harmonia. $\mathrm{O}$ imenso está tanto dentro quanto fora do sujeito e acaba levando-o a buscar o outro, pois não importa se enfrentamos essa grandeza internamente ou fora de nós, ela sempre nos aterroriza ao mesmo tempo em que nos encanta, basta retomarmos o conceito kantiano de sublime para compreender tal sensação. Essa situação é propícia ainda ao devir-imperceptível proposto por Deleuze e Guattari, sobre o qual falamos anteriormente, em que se dá um reconhecimento mútuo, terreno fértil para o relacionamento com o outro. A imensidão, portanto, é parte da transcendência imanente.

A exacerbação do "eu" culmina em um "nós" fusional, "unicamente preocupado com o prazer do estar junto aqui e agora"(MAFFESOLI;1998:106). Para Maffesoli, nesse cenário vemos surgir uma reflexão sobre a intuição, e a dimensão estética ganha destaque, principalmente pela experiência do vibrar em comum (Ibidem:137). Nesse sentido, o sociólogo francês afirma que, por mais paradoxal que possa parecer, é o apego ao concreto que serve de fundamento a uma abordagem estética da vida social que repousa sobre o compartilhamento das emoções, dos afetos e de outras coisas próprias ao senso comum (1998:167). 
Encontramos aí a sabedoria instintiva, que "não remete obrigatoriamente para razão, mas que sabe integrar essa parcela de paixão que, sabe-se, é um componente essencial da vida social. [...] É essa sabedoria popular que, como já indiquei, está na base da resistência frente a todos os poderes"(Ibidem:173). Para Didi-Huberman na sabedoria popular encontramos uma "luz de sobrevivência" que se sustenta numa experiência indestrutível, ainda que se encontre reduzida às clandestinidades. Essa experiência, segundo o autor, representa "uma força diagonal por intermitências, numa essencial liberdade de movimento" (2011:154-155).

Dessa forma, vemos que a trans-imanência se mostra como possibilidade de inserção no movimento mesmo no qual já estamos inseridos, ecoando o método da intuição proposto por Bergson e que vai carregar noções relacionadas ao fluxo, permitindo, por meio da experiência, abordar as demonstrações da estética do fluxo na contemporaneidade. Além disso, a trans-imanência também se manifesta tal como uma experiência característica da estética do fluxo nas obras de artemídia contemporânea, despertando uma relação com a imensidão interior pelo devaneio e pela imersão por meio de estímulos intermitentes ou oscilantes, num diálogo entre luz e escuridão proporcionado pela técnica que, ao final, nos remete ao imenso exterior, em que procuramos estar-junto ao outro.

Por fim, vemos que o aspecto social na trans-imanência é tão expressivo a ponto de podermos falar, como o fizemos acima, numa transcendência da sociabilidade. A importância da relação e a busca por ligar-se ao outro pautam e alimentam esse ciclo que parte da experiência e vai em direção ao compartilhamento num espaço de fluxos que Verhaghe irá chamar de espaço comunicacional (2010:326), onde redes de computadores, celulares, tablets, entre outros dispositivos munidos de acesso à rede mundial de computadores, e que perpassam o domínio da Comunicação, fazem com que essa estética não apenas dialogue com a área mas seja mesmo apropriada por ela. Nesse contexto, o papel do artista se altera como propõe Mario Costa. Para além de conceber uma obra que sirva para externar as próprias sensações, ele passa a preocupar-se com o design de processos e dispositivos que permitam ao outro vivenciar suas próprias experiências em sua busca pessoal pela transimanência, tornando-se um designer de experiências. 


\subsection{Linguagem poética e não-linear: o artista como designer de experiências}

Quando falamos do artista a partir do foco no processo de criação de dispositivos, acabamos retomando o pensamento de Mario Costa quando discorre sobre o sublime tecnológico (1995:33) e percebemos que, apesar de algumas discordâncias, existem certos pontos de seu pensamento aos quais podemos nos voltar para compreender melhor determinadas dinâmicas. Também reconhecemos a relevância do aspecto tecnológico na contemporaneidade e a forma como, ontologicamente, não podemos deixar a tecnologia de lado, pois ela transforma sempre, a cada época, nossa forma de ser-no-mundo ${ }^{164}$. Apenas damos mais destaque para o aspecto humano e como a percepção subjetiva e ligada aos vários estados de consciência pode fragmentar ainda mais a experiência do fluxo - diferentemente do filósofo italiano. Assim, concordamos com o autor quando ele diz que a experiência estética se desloca do interno ao externo no sentido em que isso "[...] se apresenta como um estado material e objetivo das coisas: a essência espiritual do produto artístico é negada e tecnologicamente transferida ao externo através de interfaces corpo-máquina" (COSTA;2010:139).

Costa afirma surgir uma ruptura da arte como linguagem que caracterizaria o fim da época da expressão (2010:140). Em lugar da personalidade artística, teríamos, então, o experimentador estético (noção apresentada logo no iníco desta pesquisa, na introdução). Nessas poucas palavras encontramos uma tal revolução de conceitos e noções! Achamos interessante a valorização da experiência no papel do experimentador estético. Acreditamos que essa é uma questão própria à contemporaneidade e que acompanha, dentre outros acontecimentos, a perda de importância individual do artista ou do autor tradicional. O gênio criativo é, aos poucos, substituído por equipes multidisciplinares em que a obra é pensada em conjunto, numa rede de ideias e intencionalidades híbridas e abertas. Dessa forma, aquele que concebe a obra inicialmente se porta como experimentador estético e chama o participador a completar essa experiência, ele também concluindo uma possível leitura da obra mediante a participação e ocupando a mesma função do (anteriormente) denominado artista ou autor — a

\footnotetext{
${ }^{164}$ Tal perspectiva vai ao encontro à compreensão de Heidegger acerca da técnica, para quem a essência da tecnologia não é tecnológica (1977:4). Tal essência estaria mais ligada à possibilidade de um desvelamento (Ibidem:12), de avistar a clareira onde o ser-aí se revela - como abordamos no primeiro capítulo. Dessa forma, o filósofo resgata a origem da palavra 'tecnologia', relacionando-a à techné grega e, consequentemente à definição primordial da arte que, apropriando-se da techné, estaria diretamente ligada à poiesis (Ibidem:13). Heidegger dá prosseguimento ao seu pensamento ao afirmar que a essência da tecnologia estaria ligada a um "emolduramento", no sentido de uma configuração que coloca o homem numa posição de revelar o real a partir de um distanciamento (Ibidem:24), de tal forma que a essência da tecnologia seria, portanto, ambígua, transitando entre a possibilidade da revelação e o vislumbre do ainda não experienciado (Ibidem:33), o que conceberia um ser-aí em contínuo devir - fluxo. Para o filósofo, a tecnologia deve ser entendida como técnica, pois a técnica liberta, enquanto a tecnologia tecnológica, restringe.
} 
de experimentador estético. A diferença entre os dois experimentadores está no fato de o artista também ser o projetor da experiência, ou, como chamamos aqui, um designer de experiências - compreendendo por design a noção flusseriana apresentada anteriormente de ligação entre arte e técnica e entre estética e ciência.

Quanto ao fim da arte como linguagem e expressão, essa é uma questão sobre a qual ainda temos muitos questionamentos. A característica híbrida e aberta das obras contemporâneas nos levam a problematizar mais do que a forma, o meio, pois aí se manifestaria o objetivo de muitas das atividades artísticas na contemporaneidade. $\mathrm{O}$ que faz sentido, tendo em vista a importância da relação ou do estabelecimento de laços sociais, sobre o qual já falamos repetidas vezes. Dessa maneira, se daria uma valorização do abstrato, do aleatório ou do que está em formação. Aí encontramos a dimensão do movimento e da constante transformação das coisas, cuja representação visual foi buscada por vários movimentos artísticos de vanguarda no início do século $\mathrm{XX}$, tais como o cubismo, o futurismo, o dadaísmo, o construtivismo russo e o suprematismo, aproximando-se do nãofigurativo. Dessa forma, retomamos a discussão acerca do design para melhor compreender como ele pode servir de ponte entre estética e ciência - como propõe Flusser - voltando-se à construção de processos artísticos. Recorreremos ainda ao pensamento reflexivo baseado nas imagens, como propõe Warburg, visto que é visualmente, por meio da composição e das formas, que a relação entre movimento e abstração se apresenta no design. Paralelamente, faremos o diálogo com a discussão acerca da linguagem (indo em direção à poesia) e da arte para problematizar a afirmação de Costa de ruptura entre os dois.

Encontramos nesses movimentos de vanguarda, bem como nas composições de design, uma poesia do não-figurativo. No poema Serenata, Cecília Meireles diz: "Há uma doce luz no silêncio”. Um único verso e poucas palavras são o suficiente para que ela nos insira em uma atmosfera própria. Suas palavras nos remetem a imagens e sensações. "A palavra é uma força que se impõe inevitavelmente, e uma de suas realidades (além do silêncio e do mistério) é a imagem que ela suscita. As imagens, do mesmo modo, também suscitam a palavra, fazendo par com a poesia." (CASTRO, 2007:112).

Tendemos a relacionar a poesia apenas às palavras e muitas vezes nos esquecemos de que as palavras nos despertam imagens. No design, o trabalho com os elementos plásticos ${ }^{165}$

\footnotetext{
165 “Os elementos propriamente plásticos da imagem (representativa ou não) são os que a caracterizam como conjunto de formas visuais e que permitem constituir essas formas: 1) a superfície da imagem, e sua organização, o que se chama tradicionalmente de composição [...]; 2) a gama de valores, ligada a maior ou menor luminosidade de cada região da imagem [...]; 3) a gama de cores e suas relações de contraste; 4) os elementos gráficos simples, especialmente importantes em toda imagem 'abstrata'; 5)a matéria da própria imagem, na medida em que proporciona a percepção."(AUMONT, 2008:136)
} 
também gera imagens que, igualmente, podem ser poéticas. Em uma composição gráfica, a disposição dos espaços positivos e negativos ${ }^{166}$ exige um conhecimento de harmonia, equilíbrio e uma sensibilidade para a relação entre os pesos das formas que acabam definindo a luminosidade do produto final - a página. É como se as formas, ou espaços positivos, fossem as palavras. E os espaços negativos, os silêncios do poema. Para se chegar a uma composição harmônica, é preciso saber equilibrar negativo e positivo; luz e sombra; silêncio e palavra - harmonia entre contrários. Portanto, pode haver, sim, uma 'luz no silêncio', como diz Cecília Meireles. Não apenas na poesia das palavras, mas também na poesia das imagens e das formas.

Gustavo de Castro diz que é pelo silêncio que se compreende a comunicação. Ora, não iniciamos esse pensamento sobre o design para melhor compreender o papel do artista como designer de experiências; como um protagonista ao proporcionar vivências de fluxo na contemporaneidade? O que faz esse mesmo artista a não ser promover relações ${ }^{167}$, ou estabelecer meios de comunicação entre ele e os participadores da obra e também entre esses mesmos? Para o autor, o silêncio é o que pontua o discurso incessante ${ }^{168}$, assim como, numa composição, os espaços negativos dão destaque à forma positiva quando transitamos em meio ao abstrato. Nossa tendência é focar na palavra ou na forma quando, se não fossem pelos silêncios e pelos vazios, não seria nem mesmo possível percebê-los: rupturas necessárias para a percepção e vivência de um fluxo.

A relação inicial que se faz entre design e poesia nos remete à poesia concreta, na qual os poetas constroem formas trabalhando a disposição das letras e palavras (tratados como parte da tipografia pelo design) de acordo com o conteúdo do poema. Nós acreditamos em uma poesia visual que se utilize de imagens abstratas, obtida a partir da relação entre luz, sombra e design, dando espaço a uma beleza livre e que abre espaço para interpretações subjetivas da forma de acordo com a relação com o criador, o contexto e o contemplador participante — tal

\footnotetext{
${ }^{166} \mathrm{O}$ espaço positivo é aquele ocupado pela forma ou objeto em uma composição. O espaço negativo é o espaço que existe em volta do objeto.

${ }^{167}$ No livro Comunicação e Poesia. Itinerários do Aberto e da Transparência (2014), Gustavo de Castro e Florence Dravet trazem uma definição de Comunicação a partir da filosofia de Heidegger, em que consideram o radical com como princípio de religação. "O princípio com torna todas as conexões possíveis"(CASTRO, DRAVET; 2014:36). Em nota de rodapé, os autores complementam o pensamento: "Temos apresentado, de forma recorrente, em congressos esta nova compreensão da comunicação. Aqui, ela é, antes, um axioma, um princípio da natureza, um eixo de atração por relação, norteador de todas as uniões, sejam elas materiais ou imateriais. (Ibidem:Idem, grifo nosso)

168 "Para conhecer a comunicação, evitar a água parada. A palavra dicionária que não leva a nenhum discurso. Há um rio que sempre corre em direção a tudo o que comunica. Por isso, para conhecer a comunicação, começar pelo silêncio. Ele é o que tudo pontua no discurso-rio. Mas o silêncio, na verdade, não existe, porque tudo é som, música, melodia. O tempo todo, a todo instante, canta-se um canto quieto. Por isso nós não ouvimos. Mas ao nascer, o sol emite um som; a flor, ao abrir-se, canta a aurora; a cadeira, inerte na sala vazia, dedilha a música da ruína; a caixa oca, sona uma ária desconhecida aos nossos ouvidos. Toda a natureza canta: o desprender-se de uma folha ou um fio de cabelo, o passar de uma nuvem, o pousar de uma pena sobre o chão. A aparente ausência de som é só aparente. Por isso a comunicação é melodia secreta. Um canto e um baile de sentidos, dança e movimento, festa com muitos con-vivas"(CASTRO;2005:16)
} 
como se dá nas instalações de artemídia, fora do papel, em espaços tridimensionais, mas relacionando-se aos mesmos princípios perceptivos e sensoriais.

Flusser ressalta ainda a ligação e relação da palavra design com outras palavras tais como máquina, técnica, ars ${ }^{169}$, kunst ${ }^{170}$. Cada um desses conceitos, segundo o autor, é impensável sem os demais (2007a:183). No entanto, desde a Renascença e, principalmente, com a ascensão da cultura moderna burguesa, houve uma separação entre arte e técnica: de um lado temos o ramo estético e, de outro, o ramo científico. Ao exprimir a conexão interna entre essas duas concepções, a palavra design, para o autor, serviria como uma ponte entre esses dois mundos (2007a:183).

Flusser levanta ainda outras significações atribuídas à palavra design, que vem do latim designare e contém em si o termo signum, que significa signo; desenho, em português. Também pode significar designar (de-signar). O design, portanto, designa as coisas do mundo, ao dar-lhes forma, assim como a palavra as nomeia. Heidegger diz que nomear faz aproximar aquilo que se evoca. Assim, designar, aproxima a coisa designada - a forma resgatada do jogo de luz e sombra. Essa dinâmica torna perceptível a separação e intimidade concomitantes entre mundo e coisa, remetendo-nos à imagem-cristal de Deleuze, que articula a virtualização/atualização de significados da imagem. Mundo e coisa se relacionam ao mesmo tempo em que permanecem distintos. Essa relação se dá no entre e na di-ferença ${ }^{171}$, como propõe Heidegger: "A claridade pura do mundo e o brilho simples das coisas dimensionam o seu entre, a di-ferença"(2007:22).

Vemos a força da dimensão estética no design em sua relação com a luz e a sombra que se fortalece ainda mais na produção de imagens abstratas, devido a sua característica poética, como veremos a seguir. O design combina técnica e arte; pragmática e poética, como propõe Catarina Moura: “captando e objetivando o que ainda não tem forma e o que está para além da forma, [...] assumindo-se neste gesto como tomada de consciência que poderia considerar-se, também, desvelamento.” (2006).

Nos voltemos agora à imagem abstrata. Para Kandinsky, a forma abstrata é expressão exterior do conteúdo interior e constituiria uma linguagem que poderia falar mais alto que a da figuração. Heidegger também acredita que "a linguagem fala". Num primeiro momento,

\footnotetext{
${ }^{169} \mathrm{O}$ equivalente latino do termo grego techné é ars, que significa, na verdade, "manobra"(Dreh). [...] Ars quer dizer, portanto, algo como "articulabilidade ou "agilidade" (FLUSSER, 2007a:183)

${ }^{170}$ Kunst quer dizer arte em alemão.

${ }^{171}$ Heidegger se refere à di-ferença como o que "mantém em separado o meio em que e pelo qual mundo e coisa são sua unidade na relação com o outro. [...] A di-ferença dá suporte ao fazer-se mundo do mundo, ao fazer-se coisa das coisas. [...] Como meio, a di-ferença é mediadora para entregar mundo e coisa para os seus modos de ser, ou seja, para o seu ser em relação ao outro, em cuja unidade ela é o suporte"(2007:19).
} 
tendemos a relacionar essa capacidade apenas à palavra, no entanto, a imagem, sendo linguagem, também pode fazê-lo. Bachelard faz uma análise da fala da imagem (poética) no livro A Poética do Espaço: "uma imagem poética põe em ação toda uma atividade linguística. A imagem poética transporta-nos à origem do ser falante.” (2008:7). Heidegger complementa sua afirmação ao dizer que a fala é, sobretudo, expressão; que pressupõe a ideia de um “interior que se exterioriza.” (2003:10). Ora, vemos aí, claramente, um diálogo com a proposta de Kandinsky, em sua definição da forma abstrata, bem como com a noção atribuída à experiência estética por Mario Costa, a partir de um deslocamento do interior ao exterior, conforme mencionamos anteriormente.

Dessa forma, podemos assumir a forma abstrata como fala e linguagem e também possível de se constituir como imagem poética. É a forma abstrata que nos serve de metáfora visual para pensar o design, ou a relação que se estabelece na experiência estética. No caso das obras de artemídia, as formas abstratas se manifestariam tanto nas disposições dos vários percursos possíveis das obras quanto nas inúmeras possibilidades de combinação entre imagens visíveis e invisíveis, que se configuram conforme a vivência de cada participador sempre um interior que se exterioriza, formando um híbrido em constante transição ou movimento; em fluxo. O resultado desses encontros é uma imagem poética, tal como considerada por Bachelard, que põe em ação uma atividade linguística.

Não acreditamos, portanto, que o abstrato - que se manifesta como imagem poética, híbrida, em fluxo - prescinda de linguagem. Alguns elementos, tal como os elementos plásticos sobre os quais falamos quando nos voltamos ao design, devem ser conhecidos, usados e problematizados quando pensamos em uma composição ou, no caso do artista multimídia, quando se pensa no design da experiência. Existe um conhecimento de linguagem que, por mais abstrata que seja a imagem ou obra, ainda não seria o suficiente para acarretar uma valorização apenas do meio (apesar de sua crescente importância) e não dos elementos necessários para constitui-la, que devem ser conhecidos e configurados pelo designer/artista. Pode ser, então, que a ruptura existente atualmente não seja entre a arte e a linguagem, como afirma Mario Costa mas, sim, entre a arte e uma estrutura narrativa tradicional, posto que essa estrutura encontra-se em aberto, para completar-se somente mediante a presença do participador.

Diante do Aberto ${ }^{172}$ nos encontramos perdidos, sem direcionamento, pois seu desamparo nos assusta. Não sabemos muitas vezes como decodificar uma linguagem aberta fragmentada,

\footnotetext{
${ }^{172}$ Estamos cientes da ampla discussão que se poderia traçar sobre o Aberto, mas nos apropriaremos de suas noções básicas, na visão de Gustavo de Castro e Florence Dravet (2014) para manter o eixo do diálogo na relação com as noções de fluxo
} 
não-linear (assim como não sabemos interpretar uma imagem abstrata) posto que "vivemos e nos construímos na representação do mundo pela linguagem e, por meio dela, agregamos nossa pessoa, pouco a pouco, camadas cada vez mais densas e opacas de sentido exterior para nossa existência."(CASTRO, DRAVET:177). Falta ao homem aprender a vivenciar a experiência de seu ser-aí diante do logos heraclitiano, em que encontramos uma coletividade originária - ou o devir-imperceptível, sobre o qual falamos outras vezes. Nesses espaços, somos-em-fluxo. Segundo Castro e Dravet, é seguindo o caminho da transparência e de sua relação com a luz que podemos pensar numa identidade aberta, na qual encontramos a poesia (2014:178), que nos permite transitar no aberto.

$\mathrm{Na}$ tentativa de tangenciar o desamparo é que buscamos traçar uma metodologia pela intuição, que valorize a experiência do pesquisador designada pelo artista (que além de experimentador estético é também um designer de experiências) num diálogo com a obra, com o próprio artista e consigo mesmo, chegando ao encontro de uma realidade híbrida, meio visível, meio invisível, entre real e virtual, contraditória, fragmentada, abstrata e em movimento. Uma relação que se constrói por uma linguagem que além de técnica também é poética, visto que promove experiências, trocas, contatos, colocando-nos em contato com o imenso que habita dentro e fora de nós mesmos.

Tomemos como exemplo a exibição Van Gogh Alive - the experience ${ }^{173}$, uma mostra multimídia apresentada entre dezembro de 2013 e março de 2014 na Frabbrica del Vapore em Milão. Mais de 3000 imagens em grandes proporções projetadas em altíssima definição tomam as paredes, teto e até mesmo o chão, intensificando a sensação de imersão do visitante pela utilização de um software chamado Sensory $4^{\mathrm{TM}}$ que controla 40 projetores e um sistema de som digital sourround ${ }^{174}$. O que vemos não são as imagens completas dos quadros do pintor mas, sim, fragmentos em movimento que exibem detalhes dos quadros, ampliando elementos, cores e texturas extraídos das telas de Van Gogh (1853 - 1890), alterando completamente a forma de se contemplar uma obra de arte da maneira como estamos acostumados em um museu tradicional, onde vemos a obra completa, em dimensões naturais, emoldurada sobre a parede.

levantadas nesta pesquisa. "O que [René] Char chamou de Espaço, [Roberto] Juarroz preferiu chamar de Aberto. Juarroz destacou o aspecto que, para ele, fora esquecido por gerações de poetas e pensadores, mesmo com representantes de peso. Juarroz, ao destacar o Aberto, diz apenas seguir a tradição Heráclito-Holderlin-Rilke-Char-Heidegger." (CASTRO, DRAVET;2014:197-198). Sobre o aberto na comunicação, Castro o relaciona à possibilidade de unir as dimensões horizontal — dos saberes técnicos e sociomidiáticos (2007:47) — e vertical — dos saberes antropoéticos e psicoespirituais (2007:48) — numa relação de complementaridade.

${ }^{173}$ Disponível em: < http://grandeexhibitions.com/traveling-exhibitions/van-gogh-alive/ > Acessado em 05/06/2014. Vídeo em DVD em anexo: pasta 'Capitulo $05>>05$.VanGoghExperience.mp4

${ }^{174}$ A empresa que organiza as exibições projetadas por meio do Sensory $4^{\mathrm{TM}}$ se chama Grande Exhibitions, de onde tiramos informações sobre o software. Disponível em: < http://grandeexhibitions.com/>. Acessado em 02/06/2014 
A experiência começa com alguns autorretratos de Van Gogh. A partir daí, seguem-se alguns "movimentos" que abordam temas diferentes relacionados à vida e à obra do artista. $\mathrm{O}$ primeiro movimento retrata a terra natal, Holanda, com pinturas que mostram personagens, paisagens e elementos do país, como os moinhos, que estão animados. É o momento em que Van Gogh pinta naturezas mortas, usando tons escuros e terrosos. O segundo movimento tem como tema a França, país para onde o pintor se transfere, especificamente Paris, que o contagia com sua energia. Ele agora se volta às flores, aos jardins e às cores mais vivas. Um trem em movimento tirado de esboços do artista faz a transição de Paris a Arles, onde Van Gogh pinta os famosos girassóis. Nesse trecho mergulhamos não apenas nas flores, mas no amarelo delas, que toma conta de todas as telas e da sala como um todo. A cor é tematizada pelas imagens e pelos trechos de cartas trocadas com o irmão, Theo. A próxima série traz o apreço pelas gravuras japonesas, que influenciaram muitos impressionistas na época. É nesse momento que o estado mental do pintor começa a piorar. As cores mudam, assim como a música. A exposição aborda esse aspecto a partir do quadro O quarto em Arles (1888), seguindo para uma sequência de vários trechos de cartas trocadas com Theo, numa busca por conhecer mais seu pensamento. O movimento seguinte mostra o período de internação no manicômio de Saint-Rémy, quando ele pinta imagens distorcidas e paisagens tranquilas. A última parte explora as amplas paisagens de Auvers-sur-Oise a partir do quadro Campo de trigo com corvos (1890) e, por fim, retornamos aos autorretratos.

Para além da fragmentação que amplia o contato com os detalhes do quadro, existe uma narrativa que conduz nossa viagem pela vida e obra do artista, com apoio de imagens em movimento, música e os textos projetados, criando uma visualização híbrida numa composição espacial abstrata, a partir de telas compostas de imagens diversas que se complementam. Como em partes diferentes do ambiente as projeções realizam animações distintas, por vezes miramos em volta sem fixar o olhar, querendo apreender o evento como um todo, mas não conseguimos. Muitos, no entanto, permanecem parados, banhando-se na luz que vem do teto, projetando as imagens no chão, como se dessa forma pudessem mesmo adentrar nelas. Aí, a narrativa se constrói a partir do conhecimento e diálogo de linguagens diversas, de forma não-linear. Ao invés de textos completos, trechos. Ao invés de um movimento único de imagem, várias imagens fragmentadas em movimentos distintos. Ao invés de uma tela, várias telas de formatos e disposições diferentes. O som parece ser a única variável mais constante a conduzir esse percurso. Cada participador escolhe como vivenciar a experiência pelo seu deslocamento (ou não) no ambiente, além do direcionamento do olhar e do tempo que decide permanecer ali, pois podemos entrar na sala durante qualquer momento 
da narrativa. Somos tomados por uma sequência de acontecimentos que não conseguimos decifrar completamente, apenas sentir. O artista único cede espaço para uma equipe, softwares e aparatos técnicos que projetam a experiência que deve ser vivenciada a partir de uma inserção no próprio fluxo, assumindo o desamparo da não compreensão total, mas da vivência estética na qual encontramos a possibilidade de construção de sentido subjetivo e aberto, ou seja, de poesia.

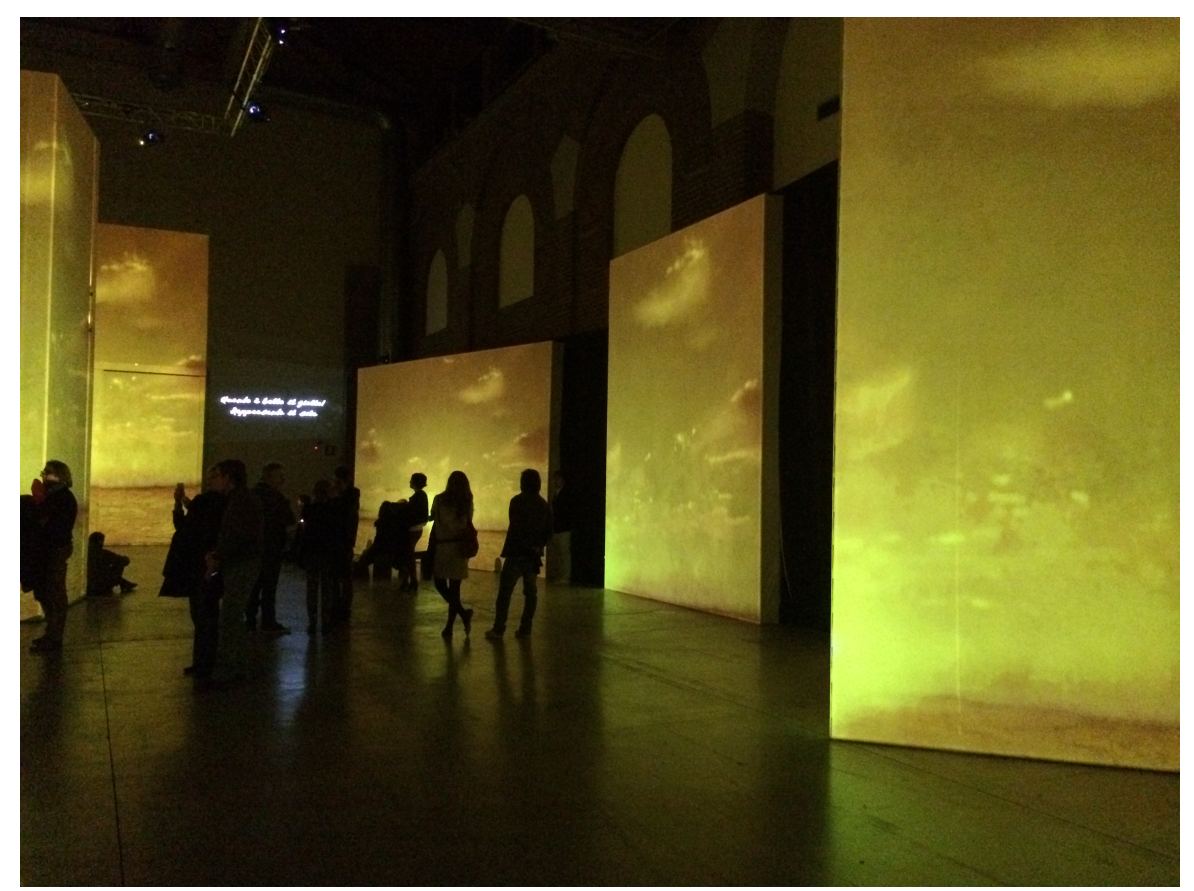

Figuras 55 e 56 (abaixo): Trecho da exposição Van Gogh Experience (2014), Fabbrica del Vapore, Milão

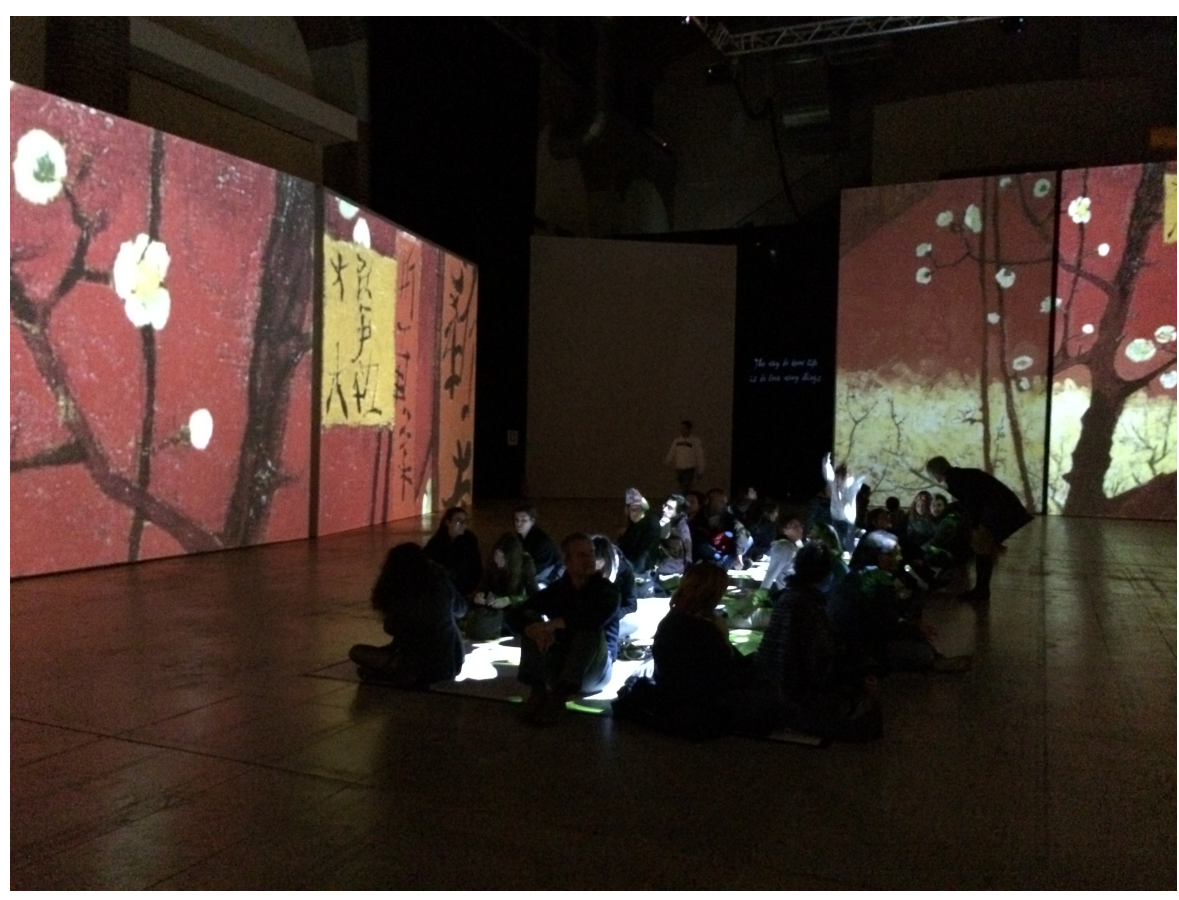




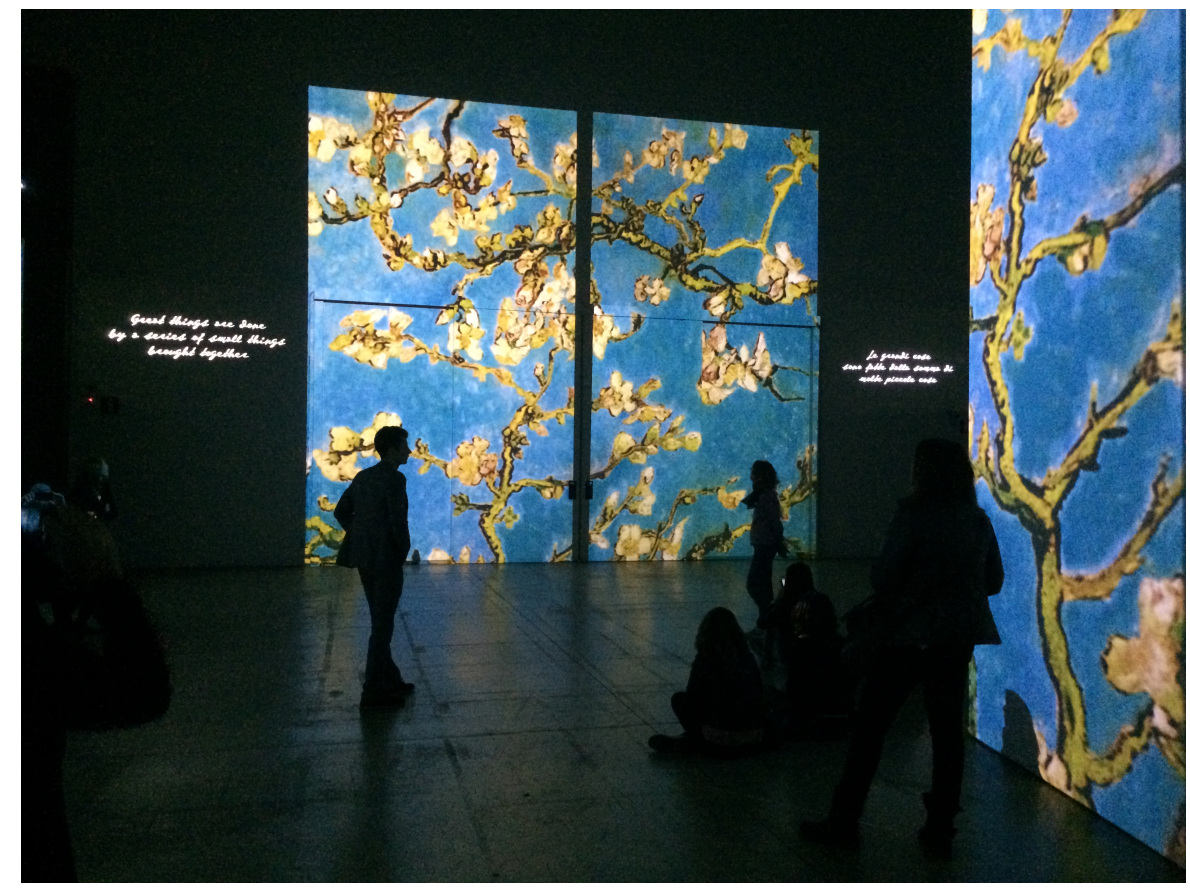

Figura 57: Trechos da exposição Van Gogh Experience (2014), Fabbrica del Vapore, Milano

Assim, concluindo a discussão acerca do fim da linguagem, não acreditamos que estejamos diante desse acontecimento, mas, sim, diante de transformações no campo da linguagem e da estética que vêm privilegiar o não-figurativo, a narrativa aberta, não-linear e em movimento. Ou seja, uma linguagem poética que também está em fluxo, assim como as imagens, a arte e nós mesmos, abrindo-se para relações híbridas diversas que possibilitem o diálogo entre arte e técnica; estética e ciência, em que o artista assume o papel de designer de experiências. Nesse cenário, temos de aprender a lidar com a constante transformação de conceitos e coisas. Aí estaria um dos grandes desafios e problemas de se pensar uma estética do fluxo.

\subsection{Da estética do fluxo à estética $\mathrm{em}$ fluxo}

Diante da instabilidade do contemporâneo, Verhaghe (2010:363) levanta três problemas no processo de se pensar uma estética do fluxo, quais seriam: 1) O que designa a estética daquilo que remete às multiplicidades proteiformes, heterogêneas, impossível de classificar segundo critérios objetivos e identificáveis? ; 2) Como, realmente, desvelar o fluxo em todas as coisas, se, por essência, se trata de considerar aquilo que se esvai no próprio olhar? ; 3) Já que o princípio do fluxo remete a um devir que devém, considerar uma estética do fluxo não seria igualmente empreender um fluxo da estética? 
Desde o início desta pesquisa tínhamos em mente o fato de que o objeto a ser analisado está em constante movimento. Nossos questionamentos acerca da forma de conduzi-la do ponto de vista do fluxo passa pelas reflexões de Bergson acerca do pensamento e o movente (num embate também com outros teóricos como Bachelard, por exemplo): é preciso inserir-se no movimento (ou no fluxo) para tentar compreendê-lo. Buscamos realizar nossas análises por meio da intuição, como propõe o filósofo francês, dando destaque à dimensão da experiência, o que consolida o diálogo desse método com a fenomenologia. Dessa forma acreditamos poder responder às duas primeiras indagações colocadas por Verhaghe e dar continuidade a uma investigação sobre a estética do fluxo.

Quando o autor questiona acerca de uma compreensão do fluxo que se enquadre em critérios de classificação objetivos e identificáveis ele já pressupõe um distanciamento (não no sentido heideggeriano) que implicaria uma imobilização do fluxo para posterior análise, incorrendo num erro metodológico, como aponta Bergson ao pensar o movente. Ele volta-se apenas à ciência, esquecendo-se da filosofia e da arte na busca por articular uma abordagem transdisciplinar e complexa que contemple a multiplicidade pelas suspensões, assim como propusemos logo no início da pesquisa ao expor a composição do tripé teórico metodológico. Ao também questionar a possibilidade de desvelar algo que se esvai no próprio olhar, Verhaghe parece não levar em consideração a dimensão não visível da experiência do fluxo. Nossa compreensão de "olhar" não se dá apenas pelo que se faz ver, mas também pelo invisível, constituindo uma visibilidade do fluxo, híbrida entre externo e interno, constituinte do devaneio e que pode se esvair, posto que é fluxo, mas que permanece na memória pósexperiência, passando a tornar-se parte das imagens mentais. Além disso, em relação à última pergunta por ele colocada, não enxergamos aí um problema pois, a partir do princípio de harmonia entre contrários (que está no cerne da noção de fluxo), não existiria contradição em uma estética do fluxo que gerasse um fluxo da estética, de forma que propomos compreender a estética do fluxo como uma estética em fluxo.

Para efetivar nossa proposta metodológica, de um ponto de vista da experiência e do fluxo, procedemos em direção à compreensão da própria experiência inicialmente por meio da descrição, não uma descrição superficial, mas sim com o intuito, como aponta Maffesoli, de buscar a significação de um fenômeno, ao invés de focar meramente em explicações causais. Dessa forma, a partir das percepções e sensações despertadas no contato com as obras, provocadas pelas suas características constitutivas, chegamos a duas categorias-fenômeno que englobam diversas manifestações do fluxo na artemídia contemporânea, que foram as da Oscilação e da Topologia Imaginária. Tais categorias-fenômeno não visam enclausurar a 
estética do fluxo em uma fórmula ou regra. O que pretendemos é expor as manifestações perceptivas de eventos e fenômenos que, por meio da experiência e da sensibilização, nos fazem relacioná-las ao fluxo e, consequentemente, a uma estética em fluxo. Ao desdobrar ainda mais tais categorias podemos reconhecer características que nos auxiliam na observação de outras obras e de diversas manifestações da contemporaneidade, a partir de um olhar estético (fluxo da estética).

Ao resgatar o trajeto que realizamos até o momento, podemos compreender a categoria da Oscilação a partir das demonstrações da relação entre luz e sombra e entre o real e o virtual nas obras observadas, ligando essa manifestação à dimensão perceptiva, que advém do estímulo visível, indo em direção ao sensorial. Essa ligação, por sua vez, se estabelece graças ao hibridismo e mediante um ritmo. Eis, portanto, as subcategorias que constituem a categoria-fenômeno da Oscilação: o hibridismo e o ritmo. Não estabelecemos uma distinção entre elas, visto que o ritmo implica ruptura, na concepção de um entre que já pressupõe uma composição híbrida.

No caso da Topologia Imaginária pudemos perceber que o cerne de sua formação rizomática está no constante diálogo entre imagens visíveis e invisíveis (ou mentais) percebidas pelo corpo que habita o espaço, o que nos remete à importância da oscilação também para a concepção de topologias imaginárias, reforçando a interação entre as duas categorias. A Topologia Imaginária se engendra num nível para além da percepção, já direcionando-se às sensações que remetem ao trânsito entre diferentes estados de consciência. Ela se caracteriza pelo aspecto do devaneio bem como da imersão — voltando-se à relevância dada à experiência do corpo. Tais seriam, portanto, as subcategorias da categoria Topologia Imaginária: o devaneio e a imersão que, por sua vez, também se confundem, visto que o devaneio pressupõe a sensação do habitar, diretamente ligada à imersão — que na contemporaneidade não se dá sem um trânsito entre visível e mental (o que implica devaneio).

Abaixo procuramos apresentar visualmente como se dariam as relações numa Estética do Fluxo entre categorias e subcategorias que encontramos na sua formação, pensando numa forma que abolisse as hierarquias, tendo em vista que apesar de algumas subcategorias dialogarem mais expressivamente na constituição de uma determinada categoria-fenômeno, elas acabam por dialogar, também, com as demais subcategorias e categoria-fenômeno, assim como destacamos no decorrer de nossa observação neste e nos capítulos anteriores. A própria dinâmica do devaneio, como citamos anteriormente, se estabelece numa oscilação (o que já implica um ritmo e uma composição híbrida) entre imagens mentais e visíveis. Ou ainda podemos citar a percepção de um ritmo, por exemplo, que se manifesta apenas mediante a 
imersão - e vice-versa. Dessa forma, as expressões de cada um desses fenômenos dialogam entre si, de forma que existam em fluxo mesmo, daí a necessidade de representá-las não como categorias estáticas, mas priorizando a relação e o movimento entre elas.

\section{ESTÉTICA EM FLUXO}

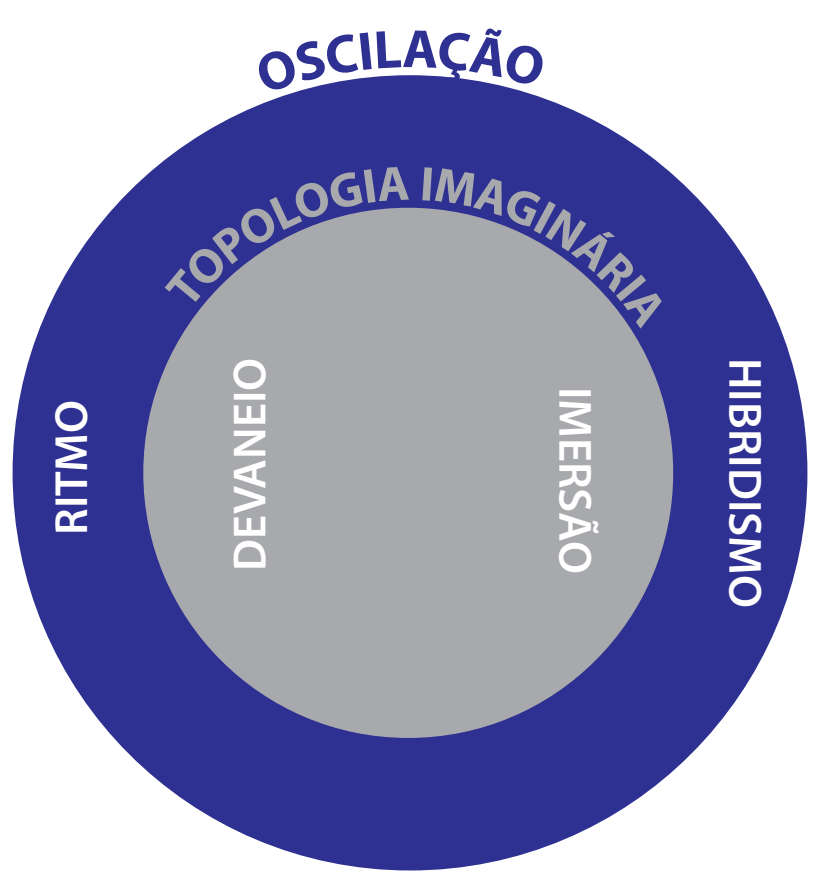

Figura 58: O diagrama da Estética do Fluxo

Nesse diagrama, portanto, os círculos significam o diálogo constante que se dá entre as subcategorias de uma mesma categoria-fenômeno. Ou seja, ritmo e hibridismo estão sempre em relação, de modo a criarem a percepção da oscilação. O mesmo acontece com o devaneio e a imersão, constantemente em diálogo na criação de topologias imaginárias. O círculo da oscilação abrange aquele da topologia imaginária, pois ao pensarmos as experiências do fluxo, partimos da percepção à consciência. Ou seja, primeiro percebemos o ritmo que existe entre os elementos distintos que compõem o estímulo visual, o que já pressupõe sua característica híbrida. A partir daí, num movimento que se direciona ao interior, como dissemos outras vezes, as imagens externas (visíveis) dialogam com a imaginação, ou seja, 
com as imagens mentais (invisíveis), reforçando o hibridismo, intensificando a sensação de imersão por meio do devaneio.

É importante lembrar que tal diagrama não pode nem deve ser estático. Ao se movimentarem, os círculos abrem possibilidade para o fluxo da estética (estética em fluxo) e podem mostrar uma maior proximidade entre uma subcategoria e outra, deixando as relações mais evidentes. É a proximidade e não a hierarquia que estabelece os padrões de relação. Tomemos o exemplo da obra Standing Wave (2013), abordada no segundo e terceiro capítulos. É a partir da oscilação das cordas que nos sentimos fundidos a elas e experimentamos o fluxo. Nesse processo, o movimento e o rimto de vibração, associados ao som, ecoam em nosso próprio corpo, fazendo com que não disntingamos mais entre o movimento real e aquele que sentimos juntamente com o vibrar das cordas — esse último, muito mais leve do que o nosso próprio corpo consegue realizar — intensificando a sensação de imersão. É a partir da percepção que se alteram os estados de consciência necessários à sensação de imersão. Ou seja, encontramos tanto o ritmo quanto o hibridismo como condicionantes de um estado imersivo (que por sua vez não se desvincula do devaneio, mas se mostra mais proeminente que esse último), no entanto, podemos priorizar o ritmo ao hibridismo na configuração dessas dinâmicas para conseguir o efeito desejado. Dessa forma, o diagrama para essa obra aproximaria a sucbcategoria ritmo, da esfera oscilação, à subcategoria imersão, da esfera da topologia imaginária, destacando essa relações por proximidade conforme podemos ver abaixo: 


\section{ESTÉTICA EM FLUXO}

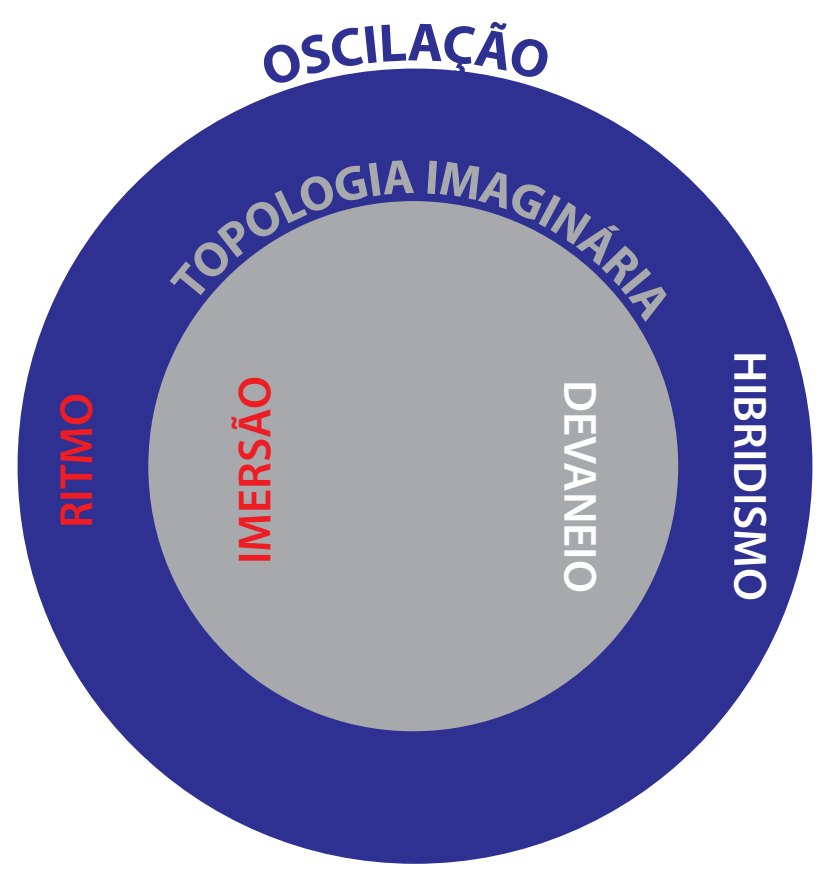

Figura 59: O diagrama da Estética do Fluxo em movimento,

segundo as dinâmicas da experiência da obra Standing Wave (2013)

Esse sistema, apesar de circular, não deixa de se guiar pelos princípios do rizoma. A imagem que fazemos do rizoma sempre remete à raiz, à infinidade de pontos que se ligam a outros pontos, tal como encontramos em sua definição, mas tais linhas se tornam muito evidentes, deixando de lado o movimento. No círculo encontramos a possibilidade de um diagrama que pode ser dinâmico, ligando todos os pontos entre si, sem criar hierarquias, sem começo nem fim, apenas estabelecendo relações concêntricas de contingência e complementaridade, como sugerido por Gustavo de Castro:

Que um sistema possa ser visto nos termos da rede, isto é, sem começo nem fim fixado e sem linhas que podem se acavalar circularmente, tornando toda circulação possível da mesma maneira, e estamos não somente num sistema aberto, como também num sistema que se define pelo tempo passado para percorrê-lo em todos os sentidos como o sistema geral de todos os sistemas possíveis. (CASTRO;2005:77) 
Tendo uma visualização de como se manifesta essa estética do fluxo, partiremos agora para uma discussão sobre como essa configuração estética influencia na nossa experiência de ser-no-mundo das imagens técnicas, levando em consideração a relação com a tecnologia, sobre a qual já nos referimos, principalmente a partir da teoria de Mario Costa. Essa é uma reflexão que se faz necessária principalmente no âmbito da Comunicação, já que grande parte das tecnologias que abordamos se encontra relacionada à área. Além disso, a relevância do aspecto social que podemos encontrar na busca pela coletividade (Heráclito) ou pelo devirimperceptível (Deleuze e Guattari) é parte importante das dinâmicas da estética do fluxo e se manifesta nos usos de mídias sociais e demais meios de comunicação na contemporaneidade, o que nos leva a um questionamento sobre a apropriação do fluxo e de sua estética pela própria Comunicação.

\subsection{A estética em fluxo na Comunicação}

No início desta pesquisa partimos da percepção de um sintoma: a manifestação do fluxo numa contemporaneidade mediada pela Comunicação. Encontramos nas Artes, especificamente na Artemídia, um campo profícuo para investigação desse sintoma, após uma melhor compreensão da própria noção de fluxo que permitisse identificá-lo na experiência das obras. Partimos da hipótese que, ao estabelecer um método em fluxo, levando em consideração a intuição e a experiência do próprio pesquisador, o fluxo se manifestaria como uma estética e, a partir daí, procuramos detalhar suas configurações. Ao se apropriarem de meios de comunicação no seu fazer artístico, vimos que a artemídia antecipa dinâmicas que posteriormente se manifestarão na comunicação, num devir midiático das artes bem como num devir artístico das mídias, conforme Ivana Bentes (In:BRUNO,FATORELLI;2006:102). Dessa maneira, tendo realizado tal percurso, retornamos à Comunicação, buscando trazer à observação algumas questões que neste momento se tornam mais claras, bem como apontar outras que deixaremos em aberto, para futuros desdobramentos.

Como dissemos anteriormente, Mario Costa irá relacionar a estética do fluxo ao que ele chama de estética da comunicação, pois acredita que a mensagem artística, na contemporaneidade, é secundária em relação ao medium e aos sistemas de troca a partir dos quais é gerada (1999:13). Costa irá privilegiar a interação pela interação. No entanto, seu posicionamento será feito a partir de uma valorização da técnica em que o sujeito se torna campo de trânsito de corrente de energia (Ibidem:35); enquanto nossa visão, mesmo considerando a importância da interação, encontra seu ponto forte no aspecto humano, ou 
seja, nas relações estabelecidas a partir das interações, seja do participador com suas imagens mentais, seja com outros participadores.

Desse ponto de vista, pensar a arte contemporânea, para o autor italiano, implica uma produção de comunicação sem informação e de criação de sistemas de sentido sem significado. Acreditamos que, ao se apropriarem de aparelhos típicos do campo da Comunicação e da tecnologia de forma geral, as Artes acabam dando ênfase à dimensão da experiência, que pode bem explorar as potencialidades de um aparelho sem necessariamente preocupar-se com a informação ou significado daquilo que é produzido. No entanto, não seria a subversão do aparelho constituinte de uma postura experimental com a técnica, como propõe Flusser? Segundo o autor tcheco-brasileiro, essa seria uma das únicas formas de se conceber uma filosofia não apenas da fotografia - como aborda em seu livro A filosofia da caixa preta (1998) — mas também das imagens técnicas na contemporaneidade.

Vemos, portanto, que a experiência é geradora de sentido subjetivo e aberto à vivência de cada participador, mesmo no âmbito da experimentação técnica; ou seja, a experiência é geradora de poesia, como vimos anteriormente. Mario Costa afirma que a vida do imaginário está sempre ligada ao estado e às possibilidades da técnica e, nesse ponto, concordamos com o autor. Basta nos lembrarmos do conceito de ontofania, que condiciona a própria manifestação do ser à técnica e ao contexto em que está inserida. Estando a técnica, na contemporaneidade, voltada ao encontro, ao estar-junto, passando justamente pelos dispositivos próprios da Comunicação, podemos dizer, como também acredita o autor, que "explorar o universo dos meios de comunicação significa, a um tempo, construir a fenomenologia do imaginário contemporâneo.” (1999:14). A esse imaginário construído pela Comunicação que associamos a noção de fluxo e, devido à relevância da experiência presente em seus processos, vislumbramos nessa construção a apropriação de elementos e fenômenos da estética do fluxo pela Comunicação .

Para Mario Costa, uma das características mais importantes de sua estética da comunicação seria o evento como algo que se subtrai da forma e se apresenta como fluxo espaço-temporal ou processo interativo e vivente (1999:32). Esse evento se caracterizaria pela necessidade de um dispositivo tecnológico de contato à distância em tempo real, promovendo um encontro ou estabelecendo uma relação. Nesse caso, a imaterialidade da energia e das tensões de campo, substituiriam o objeto estético em si, criando um sistema de rede (Ibidem:51). “A estética da comunicação não é uma teoria [...] mas uma prática. Não produz objetos mas estabelece relações."(Ibidem:68). E aí retomamos a importante noção de Comunicação como relação (CASTRO, DRAVET:2014), apresentada anteriormente, e que 
acreditamos marcar nossa discordância quanto ao pensamento de Costa. As relações estabelecidas não fortalecem apenas o meio, como propõe o italiano, mas também seus participantes, ou seja, não priorizam apenas a tecnologia, mas também o aspecto humano, tornando possível que a mediação do mundo pelas tecnologias comunicacionais nos coloque diante de uma nova configuração perceptiva de nós mesmos, construída na experiência do fluxo.

Dessa forma, consideramos que manifestações diversas no campo da Comunicação demonstram sua relação com o fluxo, principalmente aquelas mais evidentes após as transformações sofridas na área nas últimas décadas, impulsionadas pelo advento do digital e da internet, voltando o foco comunicacional mais aos procedimentos de criação do que à finalização ou ao produto em si — como também destaca Venturelli em relação aos processos artísticos (2011:61). Tais transformações, em pleno acontecimento, ainda não nos permitem vislumbrar os caminhos que se seguirão, daí a necessidade de se perceber esse estado de fluxo para uma melhor compreensão do cenário contemporâneo de um ponto de vista fenomenológico, levando em conta a percepção e a experiência, a partir de uma abordagem estética.

Conhecemos a revolução pela qual passou a área de Comunicação nos últimos quarenta anos e que levou o receptor ao status de emissor. Fala-se em comunicação integrada de forma a contemplar tanto seu aspecto técnico-tecnológico, multimídia (convergente), como os múltiplos polos de produção de conteúdo e os vários sujeitos e conhecimentos envolvidos no processo, o que implica uma postura de planejamento das estratégias dessas relações. Nesse sentido, Couchot acredita haver não mais comunicação, mas comutação híbrida e em rede (1998:156). Em tal contexto percebemos um deslocamento da atenção em direção aos processos comunicacionais. Mais importante que produzir conteúdo, por exemplo, é projetar ações ou ferramentas que tornem possível o estabelecimento de relações por meio do estímulo à participação ou à colaboração (para usar o termo mais empregado na área), gerando compartilhamento, ou seja, mais relação. Portanto, assim como na arte, a comunicação também tem experimentado a questão da participação e da interação. Para Verhaghe, a própria noção de fluidez pode ser apreendida como um sistema comunicacional que faz um apelo ao participador, a ponto da participação se tornar uma das condições mesmas da contemporaneidade (2010:357): “Aquilo que podemos apreender de um relacionamento fluido é que, face aos elementos do real, subsiste a possibilidade para o espectador de ser ele também criador." (2010:55). 
Encontramos algumas semelhanças entre os eventos e processos artísticos e comunicacionais na contemporaneidade. Podemos observar o hibridismo nas manifestações multimídia ou ainda, para usar os termos adotados na área, na convergência de mídias ou nas plataformas transmídia (ou ainda crossmedia). Nos deparamos também com o apelo à interatividade, por meio da chamada à participação e colaboração e, principalmente, na elaboração de experiências ${ }^{175}$ — de modo mais predominante na publicidade — ao abordar o público diante dos desafios estratégicos impostos pelo novo cenário que se desenha da área. Basta lembrarmos dos inúmeros casos recentes de marketing de guerrilha ${ }^{176}$ e flahsmobs ${ }^{177}$, por exemplo, principalmente vinculados a ações de publicidade e que se estabelecem sobre a projeção de experiências proporcionadas ao consumidor e relacionadas à marca, como forma de contribuir para a construção da imagem dessa mesma marca. Abordamos adiante um evento de cada um deles.

Numa ação que pode ser considerada de guerrilha, realizada em 2013 pela empresa nacional de sistemas ferroviários da França (SNCF) em parceria com a agência TBWA Paris, foram espalhadas várias instalações em formato de porta pela cidade de Paris com o nome de um destino para onde a empresa transporta passageiros, como parte da campanha "A Europa está na porta ao lado". Ao abrir a porta, o pedestre que passava pela rua encontrava um ou mais interlocutores que estavam na cidade anunciada em tempo real, prontos para interagirem com ele: um palhaço que faz mímica e imita o participador em Paris a partir da praça Duomo em Milão; um grupo de dança que ensina alguns passos desde a praça Port Vell em Barcelona; um desenhista que realiza uma caricatura estando na praça Agora em Bruxelas; um casal que mostra o lago Léman de Genebra ou ainda um grupo de amigos que anda de bicicleta pela cidade de Stuttgart a partir das direções definidas pelo participador em Paris. O vídeo $^{178}$ que mostra a ação se desenrolando deixa evidente que o tom principal da narrativa é o de mostrar a possibilidade de estar-junto, de maneira rápida e descomplicada. Graças à técnica (internet e digital), conseguimos nos comunicar pela instalação em tempo real,

\footnotetext{
${ }^{175}$ Para mais informações sobre o assunto, vide: GILMORE, James H., PINE, Joseph B. Pine. The experience economy: Work is Theatre and Every Business a Stage. Boston: Harvard Business School Press, 1999.

${ }^{176}$ Marketing de guerrilha está ligado ao planejamento de formas de engajamento não tradicionais do público, pra alcançar o resultado almejado. (MICHEL, Dorrian. LUCAS, Gavin. Guerrilla Advertising. Unconventional Branding Communication. Laurence King: London, 2006, p.18)

${ }^{177}$ Flashmobs são aglomerações instantâneas de pessoas que se organizam, atualmente, por meio de redes sociais para realizar uma determinada ação inusitada, previamente combinada. Muitas ações de publicidade têm se apropriado desse formato de evento para gerar surpresa nas pessoas em determinado lugar, despertando interesse e gerando buzz, ou seja, divulgação boca-a-boca do evento a partir de quem o testemunhou (princípio importante do marketing viral).

${ }^{178}$ Disponível em: < https://www.youtube.com/watch?v=GGW6Rm437tE > Acessado em 06/06/2014. Vídeo em DVD em anexo: pasta'Capitulo_05'> 07.SNCF.mp4
} 
apagando as barreiras espaço-temporais tal como encontramos em tantos experimentos no campo das artes, por exemplo.

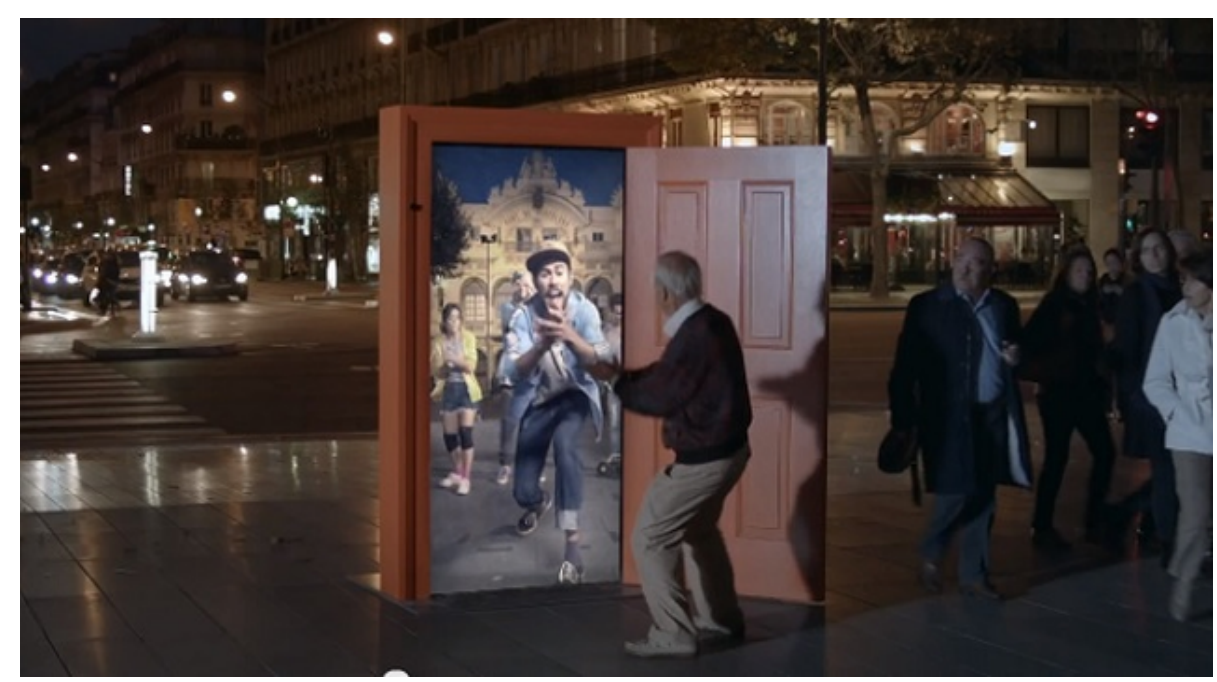

Figura 60: Cena da ação de guerrilha realizada pela SCNF em Paris

Outro evento que obteve sucesso ao estimular a relação entre as pessoas foi o flashmob organizado em 2009 pela companhia de telefones móveis T-mobile na Trafalgar Square, em Londres. A partir de uma campanha que se iniciou com vídeo-convites e panfletos, conseguiu-se reunir 13.500 pessoas na praça no dia 30 de abril para cantarem juntos a música Hey Jude dos Beatles. No vídeo ${ }^{179}$ que registrou o evento, podemos perceber o mesmo tom dado à narrativa do exemplo anterior. A empresa ainda realizou outro evento semelhante no qual várias pessoas que passavam pela estação de Liverpool começavam a dançar uma coreografia ensaiada a partir do início de uma música tocada nos alto-falantes do lugar. Ambas ações, parte da campanha "A vida é para ser compartilhada", conseguiram resultados ${ }^{180}$ de compartilhamento viral daqueles que participaram e testemunharam os eventos por meio de posts em suas páginas de redes sociais em forma de vídeos, comentários e fotos. A partir daí, outras pessoas acessavam a informação e também a passavam adiante.

\footnotetext{
${ }^{179}$ Disponível em: < https://www.youtube.com/watch?v=orukqxeWmM0 > Acessado em 06/06/2014. Vídeo em DVD em anexo: pasta'Capitulo_05'> $>08$.T_Mobile.mp4

${ }^{180}$ Os resultados de ambas ações da campanha podem ser encontrados no site UTalkMarketing. Disponível em:

$<\mathrm{http} / /$ www.utalkmarketing.com/pages/article.aspx ?articleid $=14797 \&$ title=tmobile dance integrated campaign $>\mathrm{e}$

$<$ http://www.utalkmarketing.com/pages/article.aspx?articleid=16399\&title=t-mobile-\%E2\%80\%98sing\%E2\%80\%99-

experiential-campaign $>$. Acessados em 20/09/2014
} 


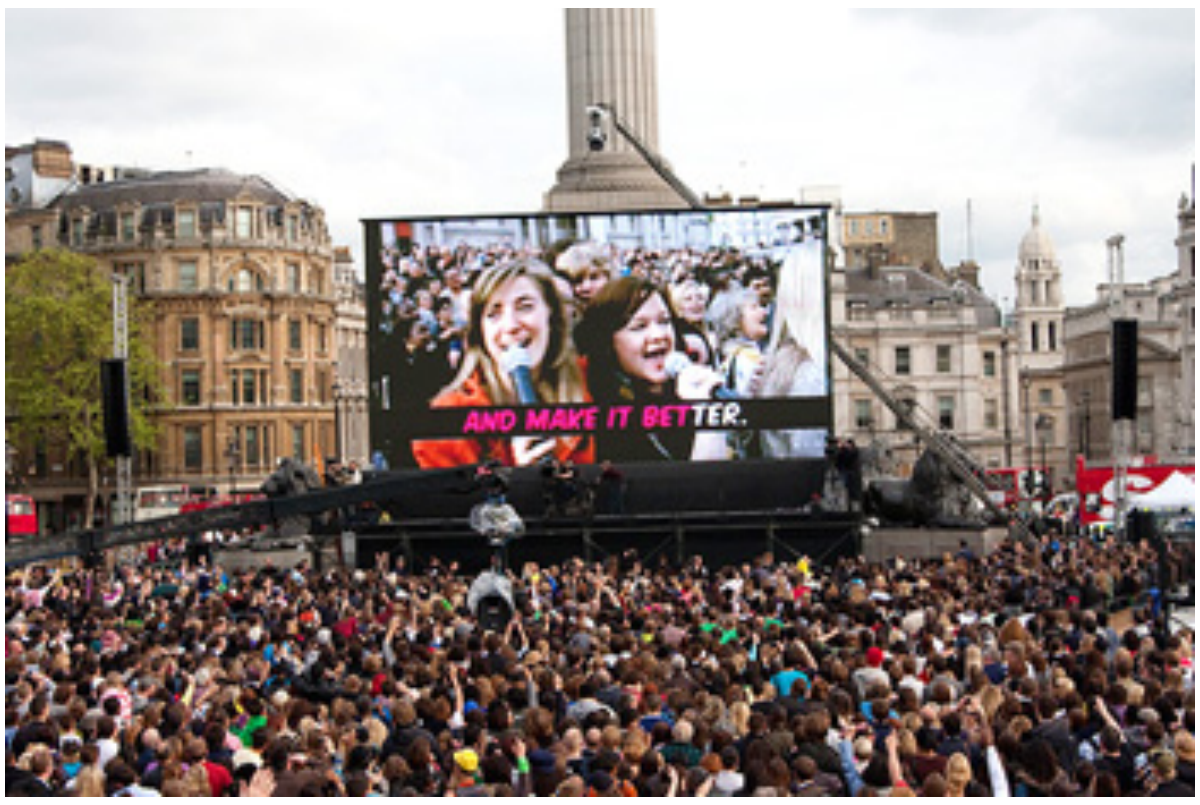

Figura 61: Multidão reunida para o flashmob da T-Mobile em Trafalgare Square, Londres

Esses eventos de comunicação acabam por transformar o receptor em emissor criativo, por meio da projeção de experiências e espaços comunicacionais, reais ou virtuais, em que se estabelecem laços sociais que tornam possível a vivência da trans-imanência por meio de dispositivos, aparelhos e outros media. Além do que o participador, tomado pela ação, é levado a compartilhá-la, a passá-la adiante. Eis que, nesse planejamento da sensibilização por meio da experiência atrelada à marca, além de procedimentos práticos, o design também entra em cena, compreendido como processo, ou seja, próximo à concepção flusseriana de união entre arte e técnica, ou entre estética e ciência, como abordamos no início deste capítulo, assim como também o faz a Comunicação, voltando-se ao pensamento das estratégias e da projeção das experiências.

Em várias das ações realizadas nesse âmbito, podemos observar que a forma de interação entre o meio e seu usuário se dá, com frequência, pela interface dos dispositivos (especialmente os dispositivos móveis), que tem se tornado cada vez mais fluida, a ponto de Couchot afirmar que de todas as hibridações para as quais o digital se encaminha, é aquela que se dá entre a máquina e o homem, por meio da interface, a mais violenta e decisiva, em que se desenrolarão todas as subjetividades (1998:226-227).

Por enquanto, a maior parte das manifestações que vemos no campo da Comunicação ainda se voltam para uma tela: a do computador, do tablet ou do telefone móvel. No entanto, assim como observamos nas experimentações propostas pelas obras de artemídia, aliadas a tecnologias como a da projeção e da holografia, podemos vislumbrar um mundo de interfaces cotidianas mais fluidas, constituídas por imagens luminosas e impalpáveis que embaralhem 
ainda mais as fronteiras entre o real e o virtual e, aliadas à internet, acabem também por diluir ainda mais as restrições espaço-temporais. O google glass, apresentado pela empresa Google em 2013, é um exemplo de dispositivo que visa fundir mais essas realidades buscando acabar com a distância física entre usuário e imagem, quando a própria retina, então, poderá ser usada como interface. Ele se assemelha a um par de óculos no qual, em frente a um dos olhos é fixada uma pequena tela, acima do campo de visão, que permite ao usuário visualizar mapas, controlar aplicativos, efetuar chamadas de vídeo e até mesmo tirar fotos ou gravar vídeos, devido à presença de uma câmera. $\mathrm{Na}$ haste dos óculos se encontra um pequeno touchpad que habilita alguns comandos por meio de cliques, além de uma saída de som. Ademais, o dispositivo também obedece a comandos de voz e está ligado à web. Todas as imagens vistas e produzidas, que se sobrepõem à paisagem do mundo visível do usuário, podem ser automaticamente compartilhadas com os amigos em tempo real.

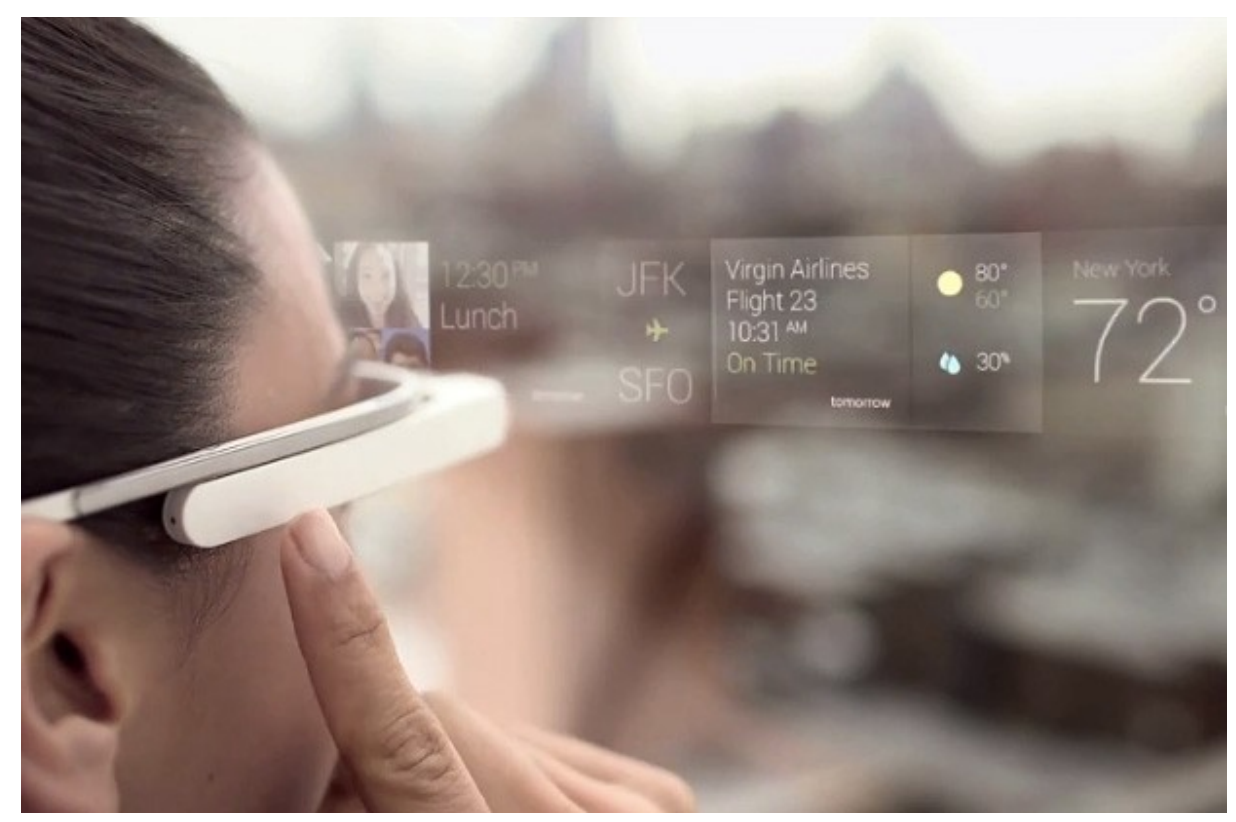

Figura 62: Simulação que mostra como a interface do Google Glass é vista pelo usuário do aparelho

Ao visualizar o vídeo ${ }^{181}$ da empresa que mostra as possibilidades de uso do google glass, percebemos que o dispositivo se integra a uma vida em movimento, tornando possível a captura de imagens fotográficas e de vídeo tal qual vistas pelo olho do usuário em seus afazeres cotidianos, como se estivesse desprovido de um aparelho (como a máquina fotográfica ou a câmera de vídeo). É como se as funcionalidades ubíquas dos smartphones, tão celebrados justamente por sua portabilidade, se tornassem ainda mais aderentes, tornando-

${ }^{181}$ Disponível em: < https://www.youtube.com/watch?v=v1uyQZNg2vE > Acessado em 07/06/2014. Vídeo em DVD em anexo: pasta'Capitulo_05 >> 09.HowItFeels_GoogleGlass.mp4 
se mais do que próteses, partes mesmo do próprio corpo. Tal produto faz parte de uma gama de pesquisas voltadas ao wearable computing (computação vestível), cujo cientista mais conhecido é Steve Mann, sobre o qual já falamos no terceiro capítulo.

Oliver Grau em seu livro Virtual Art. From illusion to immersion (2003) cita o desenvolvimento de escâneres a laser que já conseguiriam projetar imagens virtuais diretamente na retina, o que implicaria, segundo o autor, a transformação da retina em um medium (2003:205). As imagens, nesse caso, seriam visualizadas apenas pelo observador e, por não aderirem a nenhum suporte, desapareceriam logo após serem vistas, o que as transformaria em fenômenos transitórios e alteraria toda a dimensão ontológica da imagem (2003:253). Todas essas transformações levam a extensão da própria percepção do indivíduo à percepção da interface, como afirma Roy Ascott: somos todos interface (2007:319). Nesse contexto, estaríamos diante de uma cyberpercepção que envolve a convergência de processos tanto perceptivos quanto conceituais em tempo real, redefinindo nosso corpo ao nos conectarmos com os corpos de outras pessoas em todo planeta. Essa percepção é iluminada pela experiência que, por sua vez, é telematicamente compartilhada e vivenciada num espaço entre real e virtual (Ibidem:320). Segundo o autor, por meio da cyberpercepção conseguiríamos apreender o todo de uma multiplicidade de pontos de vista, possibilitando a interação total com o fluxo e o fuzz da vida (Ibidem:323).

O que Ascott chama de cyberpercepção condiz com as ideias de ontofania, a partir da qual mudanças trazidas a cada nova tecnologia alteram a percepção e, consequentemente, as experiências oferecidas ao ser em cada época. Dessa forma, diante do que discutimos até aqui e das ações que acabamos de analisar, podemos observar que grande parte dos dispositivos que respondem pelas transformações contemporâneas pertencem ao âmbito da Comunicação. As imagens por eles produzidas nos apresentam novas interfaces e realidades construídas que se assemelham àquelas das obras da artemídia contemporânea: oscilantes e híbridas, apagando as fronteiras entre o real e o virtual e, assim, intensificando a sensação de imersão nesses novos mundos - muitas vezes habitado a partir da complementação pelas imagens mentais, oriundas do devaneio intrínseco à experiência subjetiva.

O ritmo de fruição dessas imagens é pessoal, oscila de acordo com as características das experiências vividas e compartilhadas com o outro por meio dos dispositivos e interfaces mesmas que as produziram. Também os mesmos aparatos técnicos e comunicacionais são aqueles que tornam possível a produção imagética não apenas por artistas e meios de comunicação, mas por qualquer participador/usuário que tenha acesso a eles, dando vazão à dimensão criativa e à expressão de um diálogo com ideias e conceitos a partir de muitas 
mentes ao invés de apenas algumas - estimulando ainda mais o compartilhamento, a busca pelo estar-junto e as dinâmicas inerentes a vivências trans-imanentes.

Encontramos portanto, algumas recorrências da noção de fluxo por meio da experiência tanto nas vivências da artemídia quanto da comunicação. A própria utilização de recursos comunicacionais no fazer artístico da artemídia já apontava para essas relações. Além disso, vimos que o apelo à participação, ligado à necessidade de busca pelo outro e pela busca da sensação de estar-junto se apresenta tanto em um contexto como no outro, fazendo com que o artista e o comunicador passem a se comportar como um designer de experiências, focando mais nos processos que na obra ou produto em si. Procuramos, dessa forma, compreender a estética que se engendra inicialmente nas dinâmicas artísticas e que se manifesta também no âmbito comunicacional, constituindo-se num fluxo da própria estética que transita entre Artemídia e Comunicação. 


\section{CONSIDERAÇÕES FINAIS}

O estímulo inicial a esta pesquisa deu-se a partir da percepção das recorrências do uso da palavra 'fluxo', principalmente nos estudos da área de Comunicação. Procuramos investigar essa noção buscando tanto na etimologia da palavra quanto na filosofia seus significados e desdobramentos. Foi o filósofo grego Heráclito que nos serviu de guia nesse percurso. A partir das noções que aproximam o fluxo da sua concepção de logos como coletividade, bem como da ideia de totalidade na unidade (uno) e da harmonia entre contrários, procuramos tecer um fio condutor na busca pelo desmembramento desse pensamento em vários filósofos ao longo dos séculos. E, assim, estabelecemos diálogos entre Heráclito e Platão, Giordano Bruno, Heidegger, Hegel, Nietzsche, Bergson e Deleuze.

Tal etapa da pesquisa mostrou-se apropriada e necessária, pois o reconhecimento das manifestações do fluxo como sintoma da contemporaneidade só pôde ser realizado tendo esclarecido as nuances de tal conceito, ou poderíamos ter caído no senso comum de considerar o fluxo a partir apenas de sua relação com o movimento. A pesquisa etimológica, voltando-se à investigação de ideias afins à noção de fluxo, levantou ainda algumas categorias que pudemos relacionar à pesquisa filosófica, tais como: tempo, movimento, materialidade, pensamento, vontade e afeição. Foi possível perceber que várias eram as dimensões que compunham o fluxo, tais como a social e a estética.

Acreditamos que essa última dimensão, a estética, não só pode englobar as demais como também se constitui de forma social e dialética. Dessa maneira, definimos o recorte estético para a abordagem do fluxo, condicionando a pergunta sobre a possibilidade do engendramento de uma tal estética a partir de nossa primeira hipótese: a de que o fluxo na contemporaneidade se manifesta como uma estética. Após a realização da pesquisa, podemos verificar não apenas a pertinência da hipótese, como também pudemos vivenciar e experimentar tais manifestações. A dimensão da experiência, inclusive, torna-se central para nossa investigação, sendo mesmo o fundamento de uma metodologia que possa contemplar um objeto em fluxo, buscando aliar análise à intuição, como propõe Bergson.

Dessa forma vislumbramos uma experiência do fluxo que englobe tanto a memória quanto a vivência, dando destaque ao evento ou ao fenômeno, o que nos levou a voltar nossa atenção à fenomenologia, buscando as bases de compreensão dessa experiência no diálogo com a percepção e os diferentes estados de consciência. Assim, nossa segunda hipótese, e que se mostrou valiosa e fundamental na constituição dos procedimentos realizados ao longo desta 
pesquisa, foi a de que uma abordagem estética do fluxo implica considerar a experiência como criadora de devires de um ponto de vista subjetivo.

Dialogando com o método intuitivo de Bergson, procuramos nos inserir no próprio fluxo que constitui nosso objeto sem tirá-lo de seu movimento, assumindo que a experiência do pesquisador é crucial para a investigação. Mesmo nas obras que não puderam ser pessoalmente percorridas, o contato com os vídeos das obras e performances, bem como o levantamento de informações e embate com demais experiências anteriormente vividas, atribuem ao estudo uma perspectiva subjetiva necessária num primeiro momento para que, a partir da experiência, seja possível colocar em suspensão (époche) algumas práticas e articulálas posteriormente para promover o distanciamento (heideggeriano) e proceder à análise que se desenrolará na descrição do resgate da experiência. $\mathrm{O}$ caráter subjetivo não apenas é requisito para a investigação, mas para a vivência das obras de artemídia que constituem nosso corpus, visto que o artista cria espaços de interação com o objetivo de provocar uma experiência que dure enquanto o participador estiver aberto a ela, submetendo seu próprio corpo aos estímulos que fazem dialogar exterior e interior.

Escolhemos o campo das artes para realizar nossa pesquisa tendo em vista que aí encontramos um terreno fértil para o desenrolar de experiências estéticas. Recortamos ainda mais nosso olhar ao nos voltarmos para a artemídia, que se apropria de vários meios de comunicação no seu fazer artístico, explorando as potencialidades dos media que constituem a interface entre o homem contemporâneo e o mundo que habita, antecipando usos e apropriações que mais adiante repercutirão na área de Comunicação. Dessa forma, procuramos seguir o objetivo de propor uma estética do fluxo, com suas implicações, a partir do diálogo entre a noção e a experimentação fenomenológica de suas manifestações nas obras de artemídia contemporânea, o que realizamos em nossos "trajetos antropológicos" de experimentação e vivência das obras. Ao final, conseguimos propor uma estética do fluxo que se manifesta também em fluxo, delimitando categorias-fenômeno e subcategorias que a constituem, no intuito de contribuir para a compreensão de uma manifestação estética do fluxo que possa ser aplicada à observação e análise de outros eventos e fenômenos da contemporaneidade.

Tal objetivo se guiou pela seguinte pergunta: Como as recorrências do fluxo encontradas na experiência de obras da artemídia contemporânea se articulam na constituição de uma estética do fluxo que transforma a percepção do sujeito em relação a si mesmo, ao mundo e ao outro na contemporaneidade? Acreditamos ter conseguido vislumbrar tais configurações não apenas com o diagrama que apresenta visualmente a estética do fluxo e 
suas dinâmicas, mas também nas discussões que buscaram aliar arte, filosofia e ciência, relacionando a percepção do sujeito em relação a si mesmo, ao outro e ao mundo às dinâmicas do devir e da coletividade, da ontofania, e da trans-imanência.

Procuramos, para além da pesquisa, fazer um esforço no sentido de pensar uma metodologia do fluxo que dialogasse com a fenomenologia, que fosse intuitiva e tivesse na experiência subjetiva seu fundamento; que possibilitase uma abordagem a um objeto também em fluxo, sem recorrer à dicotômica separação entre sujeito e objeto - o que incorreria numa interrupção do próprio fluxo. Acreditamos ter conseguido, por meio da percepção de que a estética do fluxo se constitui numa estética em fluxo, que não apenas a abordagem estética pode ser importante num mundo tomado pela preocupação com a técnica, como também pode se constituir como método - método estético de abordagem intuitiva pela experiência.

Nesse sentido, recorremos também à proposta warburgiana que sugere processos comparativos visuais num diálogo com referências que compõem as vivências do observador, buscando aplicá-las à compreensão do estímulo perceptivo (dimensão atribuída à categoriafenômeno da oscilação, em que lidamos com a relação luz-sombra e real-virtual). Em seguida, somos levados a um diálogo com os diferentes estados de consciência (dimensão atribuída à topologia imaginária) — quando temos a constituição da experiência híbrida do fluxo.

Nesse processo, devemos considerar que as imagens em questão não são apenas as visíveis, mas também as invisíveis, que emergem da experiência sedimentada no momento da experiência vivenciada, atualizando as memórias num novo contexto espaço-temporal, como propõe Merleau-Ponty. Essa imagem é híbrida, uma imagem-cristal que se atualiza e se virtualiza, abrindo nossas percepções e sensações para a imensidão do espaço imaginário individual, que nos coloca em contato com a coletividade originária ou o devir-imperceptível, tornando possível a trans-imanência.

Tais dinâmicas criam zonas de indiscernibilidade em que, mais que conviver entre real e virtual, passamos a conviver com uma sensação de real que engloba as duas situações de forma indistinta. Transitamos entre elas como se uma só fossem. Nesse campo, a imaterialidade do fluxo ganha destaque e a experiência do corpo em meio às imagens impalpáveis nos faz experimentar a fluidez da sensação de flutuação, assim como pudemos vivenciar nas obras Standing Wave (2013), em que sentimos uma fusão do movimento do corpo ao movimento das cordas imateriais e oscilantes constituintes da videoinstalação; ou ainda em Zee (2008), cujo estado perceptivo de tabula rasa nos leva a perder qualquer noção de espaço e perspectiva. 
Tempo e espaço se reconfiguram de acordo com a experiência do participador. $\mathrm{O}$ ritmo que evidencia o hibridismo cria uma oscilação que nos coloca em contato com percepções sensoriais que, ao invés de conceber espaços bi ou tridimensionais, engendram espaços transdimensionais, tornando possível, por meio do diálogo entre imagens visíveis e mentais, desencadear processos de devaneio que geram a sensação de imersão na criação de topologias imaginárias. Esse espaço dura o tempo da experiência, daí termos, no diagrama da estética do fluxo, a categoria-fenômeno da oscilação abrangendo a da topologia imaginária, não no sentido de criar uma hierarquia, mas sim de estabelecer uma relação de complementaridade e diálogo que indica um movimento (fluxo da estética) que vai da percepção à consciência, ou da experiência ao devir, como vivenciamos na obra Criculadô (2007), de André Parente.

Nessa dimensão híbrida quanto à sua materialidade, procuramos transcender os limites de nosso próprio corpo em direção ao interior de nós mesmos e ao outro, num processo transimanente. Aí nos detemos; habitamos esse espaço híbrido em que o ser-em se trasforma no ser-com, numa dinâmica em que a experiência torna possivel o devir. Relembremos a experiência do sublime proporcionada pela obra Ondas: Um Dia de Nuvens Listradas Vindas do Mar (2006), de Katia Maciel, em que a imersão provocada pelo diálogo devaneante entre imagens visíveis e mentais (provenientes de outras experiências), nos remetem à sensação de desamparo diante do imenso, do aberto que abrange o imaginário do mar e em que nos sentimos parte de algo maior que nós mesmos, enquanto permanecemos completamente sós - devir-imperceptível que nos liga à coletividade originária. Esse sentimento de pertença, que se identifica à trans-imanência, acaba gerando não apenas uma estética, mas uma forma de ser-no-mundo; um ser-em-fluxo.

Essas dinâmicas acabam por reforçar, em nosso ponto de vista, a importância do aspecto humano na estética do fluxo, diferentemente de outras concepções tecnológicas que priorizam o meio e a produção de comunicação sem significado, implicando até mesmo uma separação entre arte e linguagem, como propõe Mario Costa. Por mais que tenhamos experimentado grandes mudanças tecnológicas nos últimos quarenta anos, não podemos condicionar apenas a esse contexto as alterações na relação do homem com o mundo. Vimos que a ontofania, ou seja, a forma como os seres se manifestam, é afetada pelas mudanças técnicas características de cada período. No entanto, diferentemente do que o deslumbramento tecnológico nos faz pensar, por trás de toda inovação técnica sempre podemos encontrar o elemento humano, o que implica uma reorganização da partilha do sensível. Da mesma forma em que não vislumbramos mais uma realidade em que se faça a distinção entre real e virtual, também defendemos uma indiscernibilidade entre homem e máquina. Nesse sentido, alguns teóricos 
acabariam deslocando seu pensamento em direção à uma maquinização do homem. Nós nos delocamos em direção oposta.

Apesar de conferir importância ao protagonismo do medium, também atribuímos importância à experiência, como defendemos ao longo de toda a pesquisa, aproximando-nos do aspecto humano. De forma que, ao olhar para as transformações sofridas pelo papel do artista - cada vez mais distante do gênio artístico renascentista — vemos que esse se coloca como experimentador estético junto ao participador que chama a interagir com a sua obra, de modo a conferi-la significado mediante essa relação. Dessa forma, além de experimentador estético, o artista deve se colocar também como um designer de experiências, dirigindo seus esforços para a projeção dos dispositivos que proporcionem experiências aos participadores, antes passivos, agora ativos.

Nesse sentido, encontramos no design uma forma de conciliar arte e técnica ou estética e ciência, como propõe Flusser, vislumbrando o artista como um designer de experiências. Nesse processo, ele se coloca na origem do ser falante, daquele que domina os elementos de linguagem para articulá-las na construção da experiência capaz de gerar imagens poéticas como propõe Bachelard - que promovem a relação (relembramos aqui da associação que fazemos entre a noção de relação e de comunicação, a partir das noções encontradas em Castro e Dravet). Na busca por criar formas de interação a partir do nada, o artista traz seu interior para o exterior, ou seja, coloca em ação dinâmicas próprias à abstração, necessárias ao engendramento de processos inacabados, instáveis e transitórios — abertos — e que se completarão apenas mediante a participação subjetiva de um interator, abrindo espaço para a dimensão poética em que muitas vezes não temos total controle da experiência, apenas a ressentimos e nos deixamos levar, tal com acontece no interior do fluxo. Este é o caso da obra Van Gogh - the experience, em que a narrativa fragmentada e não-linear nos coloca face a uma multiplicidade de possibilidades experimentais que às vezes não conseguimos decifrar, apenas sentir.

De forma que podemos perceber algumas transformações que colocam as linguagens tradicionais em cheque. Em terreno movediço a linguagem se fragmenta, torna-se nãofigurativa, não-linear, híbrida, aberta, ou seja, configura-se em fluxo e aproxima-se ainda mais da poesia. Assim, não acreditamos numa separação entre arte e linguagem, como destaca Mario Costa, mas numa reconfiguração da linguagem tal como a vislumbramos até então, de forma que ela é necessária para o estabelecimento das relações. Vemos aí um espaço para futuros desdobramentos desta pesquisa, ao relacionar fluxo, linguagem, arte e poesia, visto que não nos voltamos mais demoradamente a essa questão. 
Finalmente retornamos ao ponto de partida, ou seja, à Comunicação. Depois de vislumbrarmos as manifestações e experiências do fluxo e da estética do fluxo (ou em fluxo), podemos encontrar vários pontos de semelhança em seus desdobramentos estéticos tanto na Artemídia quanto na Comunicação. Assim como nas Artes, na Comunicação, os esforços têm se voltado mais aos processos que às finalizações. $O$ apelo à participação também tem se tornado proeminente e provocado as principais transformações pelas quais a área tem passado nos últimos quarenta anos — associadas também às novas tecnologias. Vemos, portanto, como a noção e, principalmente, a sensação de fluxo se apresenta no campo da Comunicação por meio tanto da técnica quanto dos processos produtivos e criativos, fazendo com que, mais que apropriação, a Comunicação se confunda mesmo com o conceito de fluxo, não apenas no sentido do movimento, mas também da harmonia entre contrários e do uno, como já desenvolvidos por Heráclito.

A importância da experiência bem como das dinâmicas de participação e compartilhamento - tão evidentes no campo da Comunicação, principalmente quando nos referimos às mídias sociais - se mostram, ainda, como evidências de uma repercussão da estética do fluxo na Comunicação, de forma que podemos, inclusive, levantar autores que encontram semelhanças e coincidências entre o que chamam de estética do fluxo e estética da comunicação, como no caso de Mario Costa. Além disso, percebemos que, ao olhar para as experimentações realizadas hoje pela Artemídia a partir da apropriação de dispositivos comunicacionais, podemos vislumbrar futuros desdobramentos técnicos, estéticos e ontológicos na área de Comunicação, principalmente no que diz respeito ao papel subjetivo do participador - ou usuário, como prefere a terminologia contemporânea da comunicação em tempos de interatividade.

Ao longo do último capítulo trouxemos apenas alguns exemplos e reflexões incipientes acerca da estética do fluxo na Comunicação. Indicamos, portanto, que os estudos voltados à estética do fluxo possam ser continuados, voltando-se a essa área, visto que é através dos meios de comunicação que entramos em contanto com o outro e com o mundo a nossa volta. Eles constituem a mediação com o mundo contemporâneo e trazem à tona a manifestação mais contundente de busca por socialidade nos dias atuais. Além disso, outro aspecto apenas tangenciado na pesquisa, e que merece maiores desdobramentos, é o da relação homemmáquina por meio de interfaces, que serão cada vez mais fluidas e imperceptíveis, fundindose ao próprio corpo e transformando sua superfície em interface orgânica e intuitiva. Essas transformações terão implicações estéticas, tanto visuais quanto sensoriais e sociais, visto que os processos de experiência e compartilhamento poderão se tornar ainda mais transparentes e 
instantâneos, dando um passo à frente do cenário que temos atualmente, em que a mobilidade e a ubiquidade se mostram como as conquistas mais recentes.

Iniciamos o processo de compreensão da estética do fluxo pelas Artes, especificamente a Artemídia e prosseguimos ao longo da pesquisa, até o entre, ou seja, até o vislumbre dos seus desdobramentos na área da Comunicação, dando destaque ao fluxo entre as duas áreas. Partindo das Artes acreditamos ter podido realizar a construção de uma noção embasada no diálogo entre arte, ciência e filosofia que possa servir também como um procedimento metodológico de observação de outros fenômenos da atualidade, diante da importância cada vez maior que a experiência tem adquirido nas dinâmicas contemporâneas, dialogando com os meandros do devir. 


\section{REFERÊNCIAS BIBLIOGRÁFICAS}

\section{Bibliografia citada}

AGAMBEN, Giorgio. O que é o contemporâneo e outros ensaios. Chapecó: Argos, 2009.

ANDREW, J. Dudley. As principais teorias do cinema. Rio de Janeiro: Jorge Zahar, 1989

ARANTES, Priscila. SANTAELLA, Lucia (orgs.). Estéticas tecnológicas: novos modos de sentir. São Paulo: Educ, 2008.

ARAUJO, Denize Correa. Imagens revisitadas: ensaios sobre a estética da hipervenção. Porto Alegre: Sulina, 2007.

ARISTÓTELES. De anima. São Paulo: Ed. 34, 2006.

ASCOTT, Roy. Telematic embrace: visionary theories of art, technology and consciousness. Los Angeles: University of California Press, 2003.

AZEVEDO, Francisco Ferreira dos Santos. Dicionário Analógico da língua portuguesa. 2 ed. Rio de Janeiro: Lexikon, 2010.

BACHELARD, Gaston. La dialectique de la durée. Paris: Les Presses Universitaires de France, 1963.

Paulo: Martins Fontes, 1997. . A água e os sonhos. Ensaio sobre a imaginação da matéria. São . A poética do devaneio. 2 ed. São Paulo: Martins Fontes, 2006. . A poética do espaço. 2 ed. São Paulo: Martins Fontes, 2008.

BAKER, George. Film Beyond Its Limits. Grey Room 25 (Autumn 2006). pp. 92-125. Disponível em: < http://www.mitpressjournals.org/toc/grey/-/25>

BAUDRILLARD, Jean. Simulacros e Simulação. Lisboa: Relógio d'Água: 1991.

BAUMAN, Zygmunt. Modernidade Líquida. Rio de Janeiro: Jorge Zahar Ed., 2001.

A sociedade líquida de Zygmunt Bauman. Folha de S. Paulo, 19.out. 2003, Caderno "Mais!", p. 5. Entrevista concedida a Maria Lucia Garcia Pallares-Burke.

BELLOUR. Raymond. L’Entre Images. Photo. Cinéma. Vidéo. Paris: La Différence, 2002. . L'Entre Images 2. Mots, Images. Paris: P.O.L., 1999.

BENJAMIN, Walter. Magia e técnica, arte e política. Obras escolhidas I. 7. ed. São Paulo: Brasiliense, 1994

.Charles Baudelaire: um lírico no auge do capitalismo. Obras escolhidas III 3.ed. São Paulo: Brasiliense, 1994a. Passagens. Walter Benjamin. Belo Horizonte: Editora UFMG, 2007. 
BENTES, Ivana. Mídia-arte ou estéticas da comunicação e seus modelos teóricos. In: BRUNO, Fernanda; FATORELLI, Antonio (orgs.). Limiares da imagem: tecnologia e estética na cultura contemporânea. Rio de Janeiro: MauadX, 2006, pp. 91-108.

BERGSON, Henri. Matéria e memória. Ensaio sobre a relação do corpo com o espírito. 2 ed. São Paulo: Martins Fontes: 1999. . O pensamento e o movente. São Paulo: Martins Fontes: 2006. . Duração e simultaneidade. São Paulo: Martins Fontes: 2006a. A evolução criadora. São Paulo: Ed.UNESP: 2010.

BRAGA, S.J.; PEREIRA, Isidro. Dicionário Grego-Português Português-Grego. 7 ed. Lisboa: Livraria Apostolado da Imprensa,1990.

BRUNO, Giordano. A causa, o princípio e o Uno. São Paulo: Nova Stella Editorial: 1998.

CANELAS, Carlos. Os fundamentos históricos e teóricos da montagem cinematográfica: os contributos da escola norte-americana e da escola soviética. Instituto Politécnico da Guarda. Disponível em: < http://www.bocc.ubi.pt/pag/bocc-canelas-cinema.pdf $>$. Acessado em $16 / 09 / 2014$.

CASTRO, Gustavo de. Filosofia da Comunicação. Comunicosofia. Brasília: Casa das Musas, 2005.

. “O aberto como fundamento da comunicação." In: DRAVET, F. et al. Os saberes da comunicação: dos fundamentos aos processos. Brasília: Casa das Musas, 2007. pp. 47-59.

. DRAVET, Florence. Comunicação e Poesia. Itinerários do Aberto e da Poesia. Brasília: Editora da Universidade de Brasília, 2014.

CLARK, Kenneth. Leonardo da Vinci. Rio de Janeiro: Ediouro, 2003.

COSTA, Alexandre. Heráclito. Fragmentos Contextualizados. Lisboa: Imprensa NacionalCasa da Moeda: 2005.

COSTA, Mario. O sublime tecnológico. São Paulo: Experimento 1995.

. L'estetica della comunicazione: Come il medium ha polverizzato il messaggio. Sull'uso estetico della simultaneità a distanza. Roma: Castelvecchi, 1999.

2010. . Arte Contemporanea ed estetica del flusso. Vercelli: Edizioni Mercurio,

COUCHOT, Edmond. La technologie dans l'art. De la photographie à la réalité virtuelle. Nîmes: Éditions Jacqueline Chambon, 1998.

CRARY, Jonathan. The techniques of the observer. On Vision and Modernity in the 19th Century. Cambridge: MIT Press: 1990.

CUNHA, Antônio Geraldo da. Dicionário etimológico da língua portuguesa. 4 ed. São Paulo: Lexikon, 2010. 
CUNHA, Paulo Ferreira da. O essencial sobre ritmanálise. Lisboa: Imprensa Nacional Casa da Moeda: 2012

DELEUZE, Gilles; GUATTARI, Felix. Mil platôs: capitalismo e esquizofrenia. Vol. 1. São Paulo: Ed. 34, 1995.

Mil platôs: capitalismo e esquizofrenia. Vol. 4. São Paulo: Ed. 34, 1997.

DELEUZE, Gilles. A dobra: Leibniz e o barroco. São Paulo: Papirus, 1991. . Bergsonismo. São Paulo: Editora 34, 1999.

. Diferença e Repetição. Lisboa: Relógio d'Água: 2000.

. A imagem-tempo. Cinema 2. São Paulo: Brasiliense, 2007.

. A imagem-movimento. Cinema 1. 2 ed. Lisboa: Assírio \& Alvim: 2009.

DEWEY, John. L'art comme expérience. Paris: Gallimard: 2005.

DIDI-HUBERMAN, Georges. A sobrevivência dos vaga-lumes. Belo Horizonte: Editora UFMG: 2011.

DOBAL, Susana. Três imagens para relatar esculturas impalpáveis. In: Revista Concinnitas Virtual, ano 10, volume 1, número 14, junho, 2009. Disponível em:

http://www.concinnitas.uerj.br/resumos14/dobal.pdf . Acessado em 09/11/2010.

DURAND, Gilbert. As estruturas antropológicas do imaginário: introdução à arqueotipologia geral. 3a edição. São Paulo: Martins Fontes, 2002.

EAMON, Christopher (ed.). Anthony McCall: the Solid Light Films and Related Works. San Francisco: New Art Trust: Evanston: Northwestern University Press, 2005

ECO, Umberto. Obra aberta. Forma e indeterminações nas poéticas contemporâneas. São Paulo: Perspectiva, 2007.

FINK, Eugen. HEIDEGGER, Martin. Heráclito. Barcelona: Editorial Ariel: 1986.

FLUSSER, Vilém. Língua e realidade. 3a ed., São Paulo: Annablume, 2007. . O mundo codificado. Por uma filosofia do design e da comunicação. São Paulo: Cosac Naify, 2007a.

Annablume, 2008.

O universo das imagens técnicas: elogio da superficialidade. São Paulo:

FRAGA, Tania. Caracolomobile: um simbiote interativo. Disponível em:

$<$ http://medialab.ufg.br/art/wp-content/uploads/2012/02/

CaracolomobileUmSimbioteInterativo.pdf $>$ Acessado em 16/09/2014

GOLDBERG, Itzhak. Installations. Paris: CNRS Éditions: 2014.

GRAU, Oliver. Virtual Art. From illusion to immersion. Cambridge: MIT Press: 2003.

GOMBRICH, E. H. Aby Warburg: his aims and methods. Journal of the Warburg and Courtauld Institutes. Vol. 62, 1999, p. 268-282. 
GUMBRECHT, Hans Ulrich. Pequenas Crises. Experiência estética nos mundos cotidianos. In: GUIMARÃES et. al. Comunicação e Experiência Estética. Belo Horizonte: 2006, pp. 5063

HEGEL, G. W. Friedrich. Ciência da lógica (excertos). São Paulo: Barcarolla, 2011.

HEIDEGGER, Martin. Concerning the technological. In: The quesiton concerning technology, and other essays. New York and London: Garland Publishing, 1977.

Heráclito. Rio de Janeiro: Relume Dumará: 1998.

. Caminhos na Floresta. Lisboa: Fundação Calouste Gulbenkian, 2002.

- Ser e Tempo; tradução revisada e apresentação de Márcia Sá

Cavalcante Schuback; pósfácio de Emmanuel Carneiro Leão. 3 ed. Petrópolis: Vozes, 2008.

- Marcas do Caminho; tradução de Enio Paulo Giachini e Ernildo Stein; revisão da tradução de Marco Antônio Casanova. Petrópolis: Vozes, 2008a.

HENDRICKS, Jon (org.). O que é Fluxus? O que não é! O porquê. (What's Fluxus? What's Not! Why). Brasília, Rio de Janeiro: Centro Cultural Banco do Brasil / Detroit: The Gilbert and Lila Silverman Fluxus Collection Foundation, 2002.

HUSSERL, Edmund. Idéias para uma fenomenologia pura e para uma filosofia fenomenológica: Introdução geral à fenomenologia pura. São Paulo: Ideias e Letras, 2006.

JAMESON, Frederic. Espaçø e Imagem. Teorias do pós-moderno e outros ensaios. $4^{\mathrm{a}}$ ed. Rio de Janeiro: Editora UFRJ, 2006.

KAC, Eduardo. Telepresence in art. Disponível em:

http://www.ekac.org/telepresence.art._94.html. Acessado em 12/05/2014. Originalmente publicado em inglês e em alemão na Teleskulptur, Richard Kriesche, Editor (Graz, Austria: Kulturdata, 1993), pp. 48-72. Uma versão resumida foi publicada em "Telepresence: A New Communicative Experience", Epipháneia, N. 2, March 1997, Salerno, Italy, pp. 53-55.

KANDINSKY, Wassily. Do espiritual na arte. 2a ed. São Paulo: Martins Fontes, 1996. . Ponto e linha sobre plano. São Paulo: Martins Fontes, 1997.

KANT, Immanuel. Crítica da Faculdade do juízo. 2.ed. Rio de Janeiro: Forense Universitária, 2008.

KRAUSS, Rosalind. Passagens in moderns sculpture. Cambridge: MIT Press: 1981. . A escultura no campo ampliado. (reedição). Gávea (PUC-RIO), Rio de Janeiro, no. 1, 1984, pp. 87-93.

LE BRETON, David. L'adieu au corps. Paris: Éditions Métaillé, 2013.

LEGG, Helen (ed.). Anthony McCall: film installations. Coventry: Mead Gallery, University of Warwick, 2004.

LÈVY, Pierre. O que é o virtual. São Paulo: Ed. 34, 1996. 
LUCCHESI, Bárbara. Filosofia dionisíaca. Vir-a-ser em Nietzsche e Heráclito. Cadernos Nietzsche (USP), São Paulo, no. 1, p. 53-68, 1996.

MACHADO, Arlindo. O quarto iconoclasmo e outros ensaios hereges. Rio de Janeiro: Rios Ambiciosos, 2001.

. O sujeito no ciberespaço. Anais do XXIV Congresso Brasileiro da Comunicação INTERCOM. Campo Grande, 2001a. Disponível em < http://www.portcom.intercom.org.br/pdfs/29708550691795394214029897104174778288.pdf >. Acessado em 16/09/2014.

. Arte e mídia. Rio de Janeiro: Jorge Zahar, 2010.

MACIEL, Katia (org.). Transcinemas. Rio de Janeiro: Contra Capa, 2009.

MAFFESOLI, Michel. Elogio da Razão Sensível. Petrópolis: Vozes, 1998.

. O Tempo retorna. Rio de Janeiro: Forense Universitária: 2012.

MANN, Steve (2013): Wearable Computing. In: Soegaard, Mads and Dam, Rikke Friis (eds.). "The Encyclopedia of Human-Computer Interaction, 2nd Ed.". Aarhus, Denmark: The Interaction Design Foundation. Disponível em $<$ http://www.interactiondesign.org/encyclopedia/wearable_computing.html > Acessado em 24/06/2014.

MANOVICH, Lev. The language of new media. Cambridge: MIT Press, 2001.

MCLUHAN, Marshall. Os meios de comunicação como extensões do homem. São Paulo: Cultrix, 2005.

MEDEIROS, Maria Beatriz. Aisthesis: estética, educação e comunidades. Chapecó: Argos, 2005.

MERLEAU-PONTY. Maurice. Fenomenologia da Percepção.4 ed. São Paulo: Martins Fontes, 2011.

MOHOLY-NAGY, László. Pintura, fotografia, cine y otros escritos sobre fotografía. Barcelona: Gustavo Gili, 2005.

MORIN, Edgar. Ciência com consciência. 8 ed. Rio de Janeiro: Bertrand Brasil, 2005.

América: 2002. ., et al. O problema epistemológico da Complexidade. Mira-Sintra: Europa-

MOURA, Catarina. O desígnio do design. Livro de actas - $4^{\circ}$ SOPCOM, 2006. Disponível em http://bocc.ubi.pt/pag/moura-catarina-designio-design.pdf. Acessado em 24/06/2014.

NIETZSCHE, Friederich. Os pensadores. São Paulo: Nova Cultural 1999.

. O nascimento da tragédia. São Paulo: Companhia das Letras, 2007.

A filosofia na era trágica dos gregos. Porto Alegre: L\&PM, 2012.

OLIVEIRA, Jelson R. Nietzsche e o Heráclito que ri: solidão, alegria trágica e devir inocente. Veritas (PUC-RS), Porto Alegre, v. 55, no. 3, p. 217 - 235, 2010.

PAREYSON, Luigi. Os problemas da estética. 3a ed. São Paulo: Martins Fontes, 2001. 
PLATÃO. Crátilo. Lisboa: Instituto Piaget, 2001.

POPPER, Frank. From Technological to Virtual Art.Cambridge, Massachusetts, London, England: The MIT Press, 2007.

ROUILLÉ, André. A fotografia. Entre documento e arte contemporânea. São Paulo: Senac, 2009.

SALLES, Filipe. Imagens Musicais ou Música visual. Um estudo sobre as afinidades entre o som e a imagem, baseado no filme "Fantasia"(1940) de Walt Disney. 2002. Dissertação (Mestrado em Comunicação e Semiótica) - Pontifícia Universidade Católica de São Paulo, São Paulo, 2002. Disponível em: < http://www.mnemocine.com.br/filipe/tesemestrado/>. Acessado em 24/06/2014.

SARAIVA. F.R. dos Santos. Dicionário Latino-Português. Belo Horizonte: Garnier, 2006.

SLOTERDIJK, Peter. Esferas I. Microsferología (Burbujas). 3ed. Madrid: Siruela, 2009.

SIEREK, Karl. Images oiseaux. Aby Warburg et la théorie des medias. Paris: Klincksieck: 2009.

VENTURELLI, Suzete. Arte: espaço_tempo_imagem. Brasília: Editora Universidade de Brasília, 2011.

VERHAEGHE, Julien. Esthétique du Flux dans l'art contemporain. 2010. 594 f. Tese (Doutorado em Estética, Ciência e Tecnologia das Artes) - Université Paris VIII, Paris, 2010. Disponível em: < http://www.bibliotheque-numerique-paris8.fr/eng/notices/118084Esth\%C3\%A9-tique-du-flux-dans-1\&rsquo-art-contemporain.html >. Acessado em $24 / 06 / 2014$.

VIAL, Stéphane. L'être et l'écran. Comment le numérique change la perception. Paris: Les Presses Universitaries de France: 2013.

WAGNER. Richard. The art work of the future and other works. Lincoln: Nebraska University Press: 1994.

WARBURG, Aby. L'atlas Mnémosyne. Paris: L’écarquillé (INHA), 2012.

WERTHEIM, Margaret. Uma história do espaço: de Dante à Internet. Rio de Janeiro: Jorge Zahar: 2001.

\section{Bibliografia consultada}

ALLIEZ, Eric. Deleuze, fiolosofia, virtual. São Paulo. Ed. 34:1996.

ARANTES, Priscila. @rte e mídia: perspectivas da estética digital. São Paulo: Editora Senac, 2005 .

. Arte e mídia no brasil: perspectivas da estética digital. ARS (USP),

São Paulo, v. 6, pp. 52 - 65. Disponível em: < http://www2.eca.usp.br/cap/ars6.htm> 
ARNHEIM, Rudolf. Arte e percepção visual. Uma psicologia da visão criadora. São Paulo: Cengage Learning, 2011.

BAPTISTA, Luis Antonio; LIMA, João Gabriel. Itinerário do conceito de experiência na cobra de Walter Benjamin. Princípios (UFRN), Natal, v. 20, no 33, 2013, p. 449-484.

BRUNO, Fernanda; FATORELLI, Antonio (orgs.). Limiares da imagem: tecnologia e estética na cultura contemporânea. Rio de Janeiro: MauadX, 2006.

CASTELLO BRANCO, Patrícia Silveirinha. Cinema Abstracto: da vanguarda europeia às primeiras manipulações digitais da imagem. Universidade Nova de Lisboa. Disponível em: < http://www.bocc.ubi.pt/pag/bocc-cinema-patricia.pdf>. Acessado em 16/09/2014.

CASTRO, Gustavo de. O mito dos nós: amor, arte e comunicação. Brasília: Casa das Musas, 2006.

COCCO, Ricardo. A questão da técnica em Marting Heidegger. Controvérsia (Unisinos). São Leopoldo v. 2. No. 1, 2006, pp. 34-54.

COELHO, José Teixeira. Coleção Itaú Contemporâneo - Arte No Brasil 1981-2006. São Paulo: Itaú Cultural, 2007.

2008.

. Itau Moderno - Arte No Brasil 1911-1980. São Paulo: Itaú Cultural,

DOMINGUES, Diana. A arte no século XXI. A humanização das tecnologias. São Paulo:

Editora UNESP, 1997.

DOMINGUES, Diana. VENTURELLI, Suzete (orgs.). Criação e poéticas digitais. Caxias do Sul: Educs, 2005.

DORRIAN, Michael. LUCAS, Gavin. Guerrilla Advertising. Unconventional Brand Communication. London: Laurence King: 2006.

DUBOIS, Philippe. Cinema, Vídeo, Godard. São Paulo: Cosac \& Naif, 2004.

FATORELLI, Antonio. Fotografia Contemporânea. Entre o cinema, o vídeo e as novas mídias. Rio de Janeiro: SENAC, 2013.

FERREIRA, Aurélio Buarque de Holanda. Dicionário Aurélio. 5 ed. Curitiba: Editora Positivo, 2010.

FLAXMAN, Gregory. Transcendental Aesthetics: Deleuze's Philosophy of Space. In:

BUCHANAN, Ian. LAMBERT, Gregg (editores). Deleuze and Space: Edimburg: Edimburg University Press, 2005, pp. 176-188.

GUADAGNINI, Silvia R. Gráfico Cronológico da arte e tecnologia no Brasil (1949 - 2007).

Disponível em: <http://parametros.ceart.udesc.br/linhadotempo.htm> Acessado em: 10/01/2013.

Imersão e Interação nas instalações interativas de três artistas brasileiros: Diana Domingues, Equipe Interdisciplinar SCIArts e Gilbertto Prado. 2007. 172 f. Dissertação (Mestrado em Artes Visuais) - Centro de Artes, Universidade do Estado de Santa Catarina, Florianópolis, 2007. 
GUASQUE ARAUJO, Yara R.; GUADAGNINI, Silvia R. et al. Parâmetros para o entendimento das mídias emergentes e a formação de um público especializado no Brasil, 2007. Disponível em: <p102.donau-uni.ac.at/xmlui/handle/10002/412>. Acessado em: 10/01/2013.

HOUAISS, Antonio. Dicionário Houaiss da Língua Portuguesa. Rio de Janeiro: Editora Objetiva: 2009.

ITAÚ CULTURAL. Enciclopédia Arte e Tecnologia. Disponível em:

$<$ http://www.cibercultura.org.br/tikiwiki/home.php> Acesso em: 10/01/2013.

JIMENEZ, Marc. L'Esthétique contemporaine. Tendances et enjeux. 2ème ed. Paris: Klincksieck, 2004.

JUNQUEIRA, Fernanda. Sobre o conceito de Istalação. Gávea (PUC-RJ), Rio de Janeiro, no. 14, 1996, pp. 551-569.

LÈVY, Pierre. A Inteligência Coletiva. Por uma antropologia do ciberespaço. $4^{\mathrm{a}}$.edição. São Paulo: Loyola, 2003. Cibercultura. São Paulo: Editora 34, 2009.

LOPES, Denilson. Delicadeza: estética, experiência e paisagens. Brasília: Editora UnB: Finatec, 2007

MACHADO, Arlindo. Máquina e Imaginário: O desafio das poéticas tecnológicas. 2 ed. São Paulo: EdUSP, 1996.

MACIEL, Katia (org.). Transcinemas. Rio de Janeiro: Contra Capa, 2009.

MERLEAU-PONTY. Maurice. O visivel e o invisível. São Paulo: Perspectiva, 2009.

MOHOLY-NAGY, Hattula. FIEDLER, Jeannine. László Moholy-Nagy. Color in Transparency. Photographic experiments in Color, 1934 - 1946. Göttingen, Germany: Steidl Publishers - Bauhaus-Archiv, 2006.

NARINE, Vidya; SORET, Jean-Luc. Art-Outsiders, un festival d'art númerique en France. In: International Cultural Heritage Informatics Meeting: Procedings from ICHIM 03. Paris: École du Louvre, 2003.

NAUGRETTE, Catherine (org.). Qu'est-ce que le contemporain? Volume I. Paris: L'Harmattan, 2011. . Le contemporain en Scène. Volume II. Paris: L'Harmattan, 2011.

NICOLAU, Marcos Fábio Alexandre. Sobre o começo tríadico da lógica hegeliana: o ser, o nada, o devir. Contradictio (UFPR), Paraná, v. 3, no. 1, 2011, pp. 57-65.

OSORIO, Luiz Camillo. Abraham Palatnik. São Paulo: Cosac \& Naify, 2004.

OSTHOFF, Simone. De musas a autoras: mulheres, arte e tecnologia no Brasil. ARS (São Paulo). São Paulo, vol.8 no.15, p.74-91, 2010.

PARENTE, André (org.). Imagem Máquina. A era das tecnologias do Virtual. Rio de Janeiro: Editora 34, 1993. 
PLAZA, Julio. Tradução intersemiótica. São Paulo: Perspectiva, 2008.

RANCIÈRE. Jacques. Le destin des images. Paris: La fabrique, 2003.

ROLAND, Dominique (org.). Art \& Culture(s) Numérique (s). Panorama Internacional. Paris: K.D. Presse: 2012.

RUSH, Michael. New Media Art. London: Thames \& Hudson, 2005.

SANTAELLA, Lúcia. Por que as artes e as comunicações estão convergindo? 2a edição. São Paulo: Ed. Paulus, 2007.

SANTOS, Nara Cristina. História da Arte: contexto e entorno em arte e tecnologia no Brasil. In: XXIX Colóquio do Comitê Brasileiro de História da Arte, 2009, Vitória. Anais do XXIX Colóquio do Comitê Brasileiro de História da Arte. Disponível em:

$<$ http://www.cbha.art.br/coloquios/2009/coloquio_2009anais.html $>$. Acessado em 10/01/2013.

SHANKEN, Edward. Cybernetics and Art: Cultural Convergence un the 1960s. In: CLARK, Bruce; HENDERSON, Linda Dalrymple (eds.). From Energy to Information. Palo Alto: Stanford University Press, 2002, pp. 155-177.

WEISZFLOG, Walter. Michaelis. Moderno Dicionário da Língua Portuguesa. São Paulo: 2004.

WORMS, Anne-Cécile. Arts Numériques. Tendances | Artistes | Lieux e Festivals. Paris: M21 Éditions, 2008. 